PHILIP VON PRITZELWITZ

\title{
INVESTIGAÇÃO DO DESGASTE DE FREIOS E EMBREAGENS EM \\ PRENSAS MECÂNICAS
}

SÃO PAULO 


\section{PHILIP VON PRITZELWITZ}

\section{INVESTIGAÇÃO DO DESGASTE DE FREIOS E EMBREAGENS EM PRENSAS MECÂNICAS}

Tese apresentada à Escola Politécnica da Universidade de São Paulo para obtenção do título de Doutor em Engenharia 


\section{PHILIP VON PRITZELWITZ}

\section{INVESTIGAÇÃO DO DESGASTE DE FREIOS E EMBREAGENS EM PRENSAS MECÂNICAS}

Tese apresentada à Escola Politécnica da Universidade de São Paulo para obtenção do título de Doutor em Engenharia

Área de concentração:

Engenharia Metalúrgica e de Materiais

Orientador: Prof. Dr. Hélio Wiebeck

SÃO PAULO

2010 
Este exemplar foi revisado e alterado em relação à versão original, sob responsabilidade única do autor e com a anuência de seu orientador.

São Paulo,07de julho de 2010.

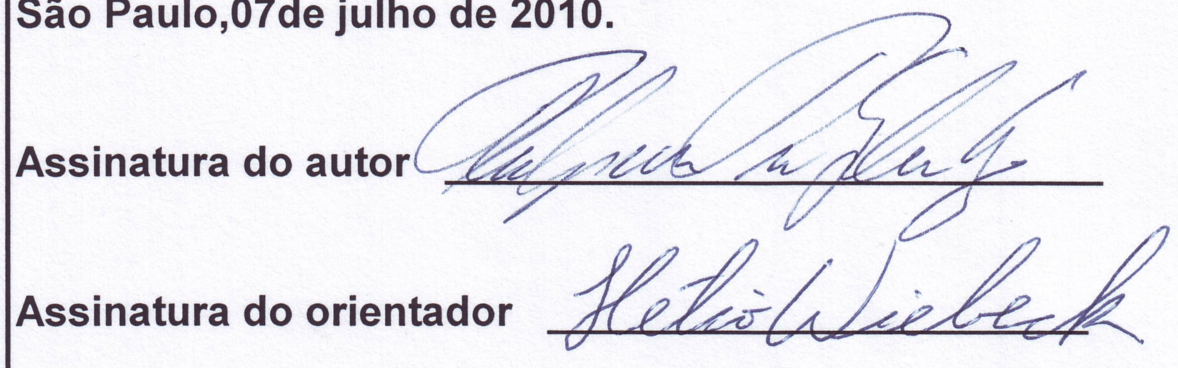

FICHA CATALOGRÁFICA

Pritzelwitz, Philip von

Investigação do desgaste de freios e embreagens em prensas meânicas / P. von Pritzelwitz. -- ed.rev. -- São Paulo, 2010. $134 \mathrm{p}$.

Tese (Doutorado) - Escola Politécnica da Universidade de São Paulo. Departamento de Engenharia Metalúrgica e de Materiais.

1.Prensas 2.Embreagem 3.Freios 4.Desgaste 5.Tribologia I.Universidade de São Paulo. Escola Politécnica. Departamento de Engenharia Metalúrgica e de Materiais.t. 


\section{AGRADECIMENTOS}

A minha esposa Rose que teve a paciência de dividir nosso tempo com esse trabalho e sempre teve uma palavra de apoio e incentivo.

Ao meu orientador Prof. Dr. Hélio Wiebeck que me acolheu, me ensinou o que são polímeros e que com o convívio nos tornamos amigos.

Ao Prof. Dr. Amilton Sinatora que me ensinou o que é tribologia, que me abriu as portas do Laboratório de Fenômenos de Superfície permitindo meus ensaios e que também com o convívio nos tornamos amigos.

Ao Prof. Dr. Francisco R. Valenzuela Diaz e ao Prof. Roberto M. Souza pelo apoio e conselhos na elaboração desse trabalho.

Ao Eng. Doutorando Mário Vitor Leite, Eng. Dr. Vanderlei Ferreira pelas sugestões e apoio no desenvolvimento deste trabalho.

Aos técnicos do Laboratório de Fenômenos de Superfície da USP: Francisco dos Reis Faustino, Leandro Justino de Paula e Raquel Camponucci Proiete pelo suporte dados aos ensaios 


\section{RESUMO}

Embreagens de prensas mecânicas, principalmente as de forja a quente se caracterizam por um intenso regime de trabalho com espaços muito curtos entre acionamentos. Muitas das embreagens apresentam desgaste acentuado obrigando a paradas frequentes para manutenção.

Neste trabalho são discutidos os princípios de funcionamento de prensas excêntricas e os parâmetros de projeto de embreagens e freios. Pontos importantes são: o balanço entre torque de operação, número de inserções por minuto e a dissipação de calor.

É feita uma breve revisão da literatura sobre compósitos, lonas e seu comportamento. Discute-se a diferença das premissas de projeto de uma lona automotiva e a lona para uso industrial com alto número de aplicações por minuto.

Apresenta-se um pressuposto quanto ao processo de transmissão de calor na embreagem e o que influência no desgaste da mesma, relacionando-o com a pressão de contato.

Nas manutenções se verificam resíduos ("debris") diferentes sugerindo regimes diferentes de desgaste. Há um resíduo preto que caracteriza um regime severo de desgaste. Pode-se associar esse resíduo ao fenômeno da degradação da base polimérica que compõe a lona. A degradação da base polimérica é causada pela alta temperatura de operação dessas embreagens.

Em ensaios simples de pino e disco consegue-se reproduzir desgaste das lonas, que comprova o observado na prática e as condições que isso ocorre.

Finalmente são apresentadas sugestões para o dimensionamento das embreagens e cuidados necessários no projeto de freios e embreagens. 


\begin{abstract}
Mechanical press clutches, especially clutches for hot forging presses have a hard working cycle with a little time between engagements. Many of those clutches present a severe lining wear, needing frequent maintenance stops.

This work is discusse, the basics of eccentric presses and the clutch design parameters. Important points are: the balance between operation torque, engagements per minute and heat dissipation.

This also presents a short literature review regarding composites and linings. It is discussed the design baselines differences between automotive linings and this specific case.

It is presented a hypothesis about the heat transfer process in the clutch and how it's related with wear, associating it with the contact pressure.

In maintenance it is found different kinds of wear debris, suggesting more than one wear regime. The black debris indicates a severe wear regime. This debris can be associated to the lining polymeric matrix degradation. The polymeric matrix degradation is caused by the high operation temperatures in these clutches.

Based on simple pin-on-disc tests can be obtained results that show what is practical observed and the conditions this occurs, proving the hypothesis.

Finally are presented suggestions for clutch dimensioning and necessary project cares.
\end{abstract}




\section{LISTA DE FIGURAS}

Figura 1.1: Resíduos de uma embreagem

pág. 02

Figura 1.2: Ampliação da figura 1.1

pág. 02

Figura 2.1: Prensa de $50.000 \mathrm{t}$.

pág. 05

Figura 2.2: Prensa de $1000 \mathrm{t}$

pág. 07

Figura 2.3: Prensa de $2500 \mathrm{t}$.

pág. 07

Figura 2.4: Fluxograma de projeto

pág. 08

Figura 2.5: Embreagem $150.000 \mathrm{~N} \mathrm{x} \mathrm{m}$

pág. 10

Figura 2.6: Embreagem $150.000 \mathrm{~N} \mathrm{x} \mathrm{m}$, corte ilustrativo

pág. 10

Figura 2.7: Válvula de dupla segurança conforme PPRPS

pág. 11

Figura 2.8: Fluxo esquemático troca de calor

pág. 11

Figura 2.9: Embreagem $980.000 \mathrm{~N} \mathrm{x} \mathrm{m}$

pág. 12

Figura 2.10: Embreagem $980.000 \mathrm{~N} \mathrm{x} \mathrm{m}$, corte ilustrativo

pág. 13

Figura 2.11: Análise térmica embreagem Airflex

pág. 15

Figura 2.12: Análise térmica embreagem $980.000 \mathrm{~N} \mathrm{x} \mathrm{m}$

pág. 15

Figura 2.13: Curva de aquecimento da embreagem de $980.000 \mathrm{~N} \mathrm{x} \mathrm{m}$ pág. 16

Figura 2.14: Processo produtivo de lonas de embreagem

pág. 18

Figura 2.15: Esquema do contato

pág. 24

Figura 2.16: Tribossistema

pág. 25

Figura 2.17: Interações Tribológicas e Mecanismos de Desgaste

pág. 25

Figura 2.18: Contato entre um material mole com outro rígido com asperezas

pág. 26

Figura 2.19: $\mu$ (coeficiente de atrito) e $\eta$ (temperatura) $x \mathrm{nv}$ adimensional de velocidade

pág. 27

Figura 2.20: Coeficiente de Atrito e Taxa de Desgaste x Temperatura pág. 28

Figura 2.21: Desgaste de materiais de atrito com reforço de asbestos

Figura 2.22: Ensaios de desgaste em função da temperatura

pág. 30

Figura 2.23: Coeficiente de atrito $x$ temperatura pág. 31

Figura 2.24: Efeito da temperatura na faixa de desgaste pág. 32

Figura 3.1: Resíduos avermelhados pág. 33 pág. 35

Figura 3.2: Resíduos pretos pág. 36

Figura 3.3: Diagrama de Ashby modificado pág. 37 
Figura 4.1: Lona utilizada, aumento $10 \mathrm{x}$.

pág. 39

Figura 4.2: Detalhe da figura 4.1 (ampliação $20 \mathrm{x}$ )

pág. 40

Figura 4.3: Lona utilizada, aumento $10 \mathrm{x}$.

pág. 40

Figura 4.4: Detalhe da figura 4.3 (ampliação $20 \mathrm{x}$ )

pág. 41

Figura 4.5: Plint TE 67

pág. 42

Figura 4.6: Detalhe do cabeçote da máquina

pág. 43

Figura 4.7: Corpo-de-prova - Iona

pág. 44

Figura 4.8: Montagem corpo-de-prova.

pág. 44

Figura 4.9: Montagem do corpo-de-prova colado.

pág. 45

Figura 4.10: Suporte para encaixe da lona.

pág. 45

Figura 4.11: Nova montagem do corpo de prova.

pág. 46

Figura 4.12: Contra-corpo

pág. 47

Figura 4.13: Foto de um contra-corpo (sem acabamento)

pág. 47

Figura 4.14: Foto de um contra-corpo

pág. 48

Figura 4.15: Ampliação da fig. 4.14

pág. 48

Figura 4.16: Micrografia do contra-corpo fig. 4.13

pág. 49

Figura 5.1: Perda de massa nos ensaios de forno

pág. 51

Figura 5.2: Modelo de compósito

pág. 52

Figura 5.3: Cargas de convecção

pág. 53

Figura 5.4: Análise térmica para 10 inserções $/ \mathrm{min}$ e $2 \mathrm{kgf} / \mathrm{cm}^{2}$, modelo com abrasivos maiores

pág. 54

Figura 5.5: Análise térmica para 10 inserções $/ \mathrm{min}$ e $2 \mathrm{kgf} / \mathrm{cm}^{2}$, modelo com abrasivos menores

pág. 55

Figura 5.6: Detalhe da figura 5.4.

pág. 55

Figura 5.7: Detalhe da figura 5.5.

pág. 56

Figura 5.8: Análise térmica para 4 inserções $/ \mathrm{min}$ e $4 \mathrm{kgf} / \mathrm{cm}^{2}$

pág. 56

Figura 5.9: Detalhe da figura anterior.

pág. 57

Figura 5.10: Resultados simulações para $2 \mathrm{kgf} / \mathrm{cm}^{2}$ de pressão de contato.

pág. 57

Figura 5.11: Temperaturas máximas e médias na face da lona central da embreagem da UC 1600

pág. 58

Figura 5.12: Temperatura média na face dos compósitos virtuais pág. 59

Figura 5.13: Temperatura máxima na face dos compósitos virtuais

pág. 59 
Figura 5.14: Resultados das simulações para o compósito com abrasivos maiores e tempo entre inserções de $2 \mathrm{~s}$ e $4 \mathrm{~s}$

pág. 60

Figura 5.15: Resultados das simulações da UC 1600 com tempo entre inserções de $2 \mathrm{~s}$ e $4 \mathrm{~s}$

pág. 60

Figura 5.16: Distribuição de temperaturas para $0,8 \mathrm{kcal} / \mathrm{cm}^{2} / \mathrm{h}$ pág. 63

Figura 5.17: Temperatura máxima $x$ capacidade de dissipação pág. 63

Figura 5.18: Modelo com rasgos radiais pág. 64

Figura 5.19: Modelo com rasgos em " $X$ " pág. 64

Figura 5.20: Coeficiente de atrito ensaio de $100 \mathrm{~N}$ a $100 \mathrm{RPM}$.

Figura 5.21: Coeficiente de atrito ensaio de $200 \mathrm{~N}$ a 100 RPM.

Figura 5.22: Coeficiente de atrito ensaio de $100 \mathrm{~N}$ a $500 \mathrm{RPM}$.

Figura 5.23: Coeficiente de atrito ensaio de $200 \mathrm{~N}$ a $500 \mathrm{RPM}$.

Figura 5.24: Coeficiente de atrito ensaio de $250 \mathrm{~N}$ a $500 \mathrm{RPM}$.

Figura 5.25: Coeficiente de atrito ensaio de $100 \mathrm{~N}$ a 750 RPM.

pág. 66

pág. 67

pág. 68

pág. 68

pág. 69

Figura 5.26: Coeficiente de atrito ensaio de $100 \mathrm{~N}$ a 1500 RPM.

pág. 69

Figura 5.27: Contra corpos após ensaio.

pág. 70

pág. 72

Figura 5.28: Contra corpo após ensaio com $240 \mathrm{~N}$.

pág. 73

Figura 5.29: Coeficiente de atrito no ensaio com carga de $60 \mathrm{~N}$.

pág. 74

Figura 5.30: Coeficiente de atrito no ensaio com carga de $180 \mathrm{~N}$.

pág. 74

Figura 5.31: Coeficiente de atrito no ensaio com carga de $240 \mathrm{~N}$.

pág. 75

Figura 5.32: Temperaturas com carga de $60 \mathrm{~N}$

pág. 76

Figura 5.33: Temperaturas com carga de $100 \mathrm{~N}$

pág. 77

Figura 5.34: Temperaturas com carga de $120 \mathrm{~N}$

pág. 77

Figura 5.35: Temperaturas com carga de $180 \mathrm{~N}$

pág. 77

Figura 5.36: Temperaturas com carga de $240 \mathrm{~N}$

pág. 78

Figura 5.37: Corte da figura 5.47

pág. 78

Figura 5.38: Temperatura $x$ pressão de contato

pág. 79

Figura 5.39: Temperatura $x$ potência térmica por área

pág. 79

Figura 5.40: Variação do coeficiente de atrito em ensaios.

pág. 82

Figura 5.41: Resultados consolidados de simulações e ensaios

pág. 83

Figura 6.1: Pontos de projeto e operação da UC1000 e UC1600

pág. 86 


\section{LISTA DE TABELAS}

Tabela 2.1: Materiais comerciais: resina e temperaturas de trabalho

pág. 21

Tabela 2.2: Materiais comerciais e suas fibras

pág. 22

Tabela 2.3: Velocidades Típicas em Prensas

pág. 23

Tabela 4.1: Condições da primeira bateria de ensaios.

pág. 49

Tabela 4.2: Condições da segunda bateria de ensaios.

pág. 50

Tabela 5.1: Perda de massa nos ensaios

pág. 71

Tabela 5.2: Condições usadas nas simulações

pág. 76

Tabela 5.3: Coeficientes de atrito a frio obtidos nos ensaios

pág. 81

Tabela 5.4: Coeficientes de atrito a quente obtidos nos ensaios.

pág. 81

Tabela 5.5: Coeficientes de atrito acima do esperado.

pág. 82 


\section{LISTA DE ABREVIATURAS}

ABNT: Associação Brasileira de Normas Técnicas

ASTM: Sociedade Americana de Testes de Materiais ("American Society of Testing Materials")

COPNA: Resina aromática polinuclear condensada ("Condensed Polynuclear Aromatic Resin")

DIN: Normas Industriais Alemãs (“Deutsche Industrie Normen”)

GPM: golpes por minuto, unidade usual em prensas

PEEK: Poli (éter éter cetona)

PMI: Ponto Morto Inferior

PMS: Ponto Morto Superior

PPRPS: Plano Prevenção de Riscos em Prensas e Similares

PTFE: Politetrafluoroetileno

PVB: Polivinil Butiral

rpm: Rotação por minuto

SAE: Sociedade dos Engenheiros Automotivos ("Society of Automotive Engineers") 


\section{LISTA DE SÍMBOLOS}

$\begin{array}{ll}\text { A } & \text { Área real de contato } \\ \text { AW } & \text { Volume perdido por desgaste } \\ & \text { Força devido a adesão (forças de van der Waals, interações de dipolo, } \\ \text { Fdef } & \text { ligações de hidrogênio e cargas elétricas) } \\ & \text { Força devido a deformação (deformação das asperezas dos polímeros, } \\ \text { I } & \text { perda de energia por histerese e sulcamento) } \\ \mu & \text { Inércia relativa ao eixo de rotação } \\ \text { T } & \text { Coeficiente de atrito } \\ \mathrm{t} & \text { Tensão de cisalhamento das uniões adesivas } \\ \mathrm{P} & \text { Tempo de escorregamento } \\ \mathrm{V} & \text { Pressão normal } \\ \mathrm{Vf} & \text { Velocidade de relativa de deslizamento } \\ \mathrm{Vm} & \text { Fração do volume relativo à fibra } \\ \omega & \text { Fração do volume relativo à matriz }\end{array}$




\section{SUMÁRIO}

Agradecimentos

Resumo

Abstract

iii

Lista de Figuras iv

Lista de Tabelas vii

Lista de Abreviaturas viii

Lista de Símbolos ix

1- Introdução

pág. 01

2- Revisão Bibliográfica

2.1- Prensas

pág. 05

2.2- Freios e embreagens em prensas

pág. 09

2.3- Construção de lonas e tipos de materiais

pág. 17

2.3.1- Compósitos

pág. 19

2.3.2- Abrasivos

pág. 19

2.3.3- Material base - base polimérica

pág. 20

2.3.4- Fibras

pág. 21

2.4- Desgaste de lonas

pág. 23 
2.4.2- Coeficiente de atrito, taxa de desgaste e suas influências em freios e embreagens

pág. 27

3- Objetivos da investigação pág. 34

4- Materiais e Métodos

4.1- Escolha de uma lona para ensaios

pág. 38

4.1.1- Descritivo de sua composição pág. 38

4.1.2- Determinação da perda de massa em função da temperatura pág. 39

4.2- Ensaios pino-disco pág. 42

4.2.1- Ensaio contato constante pág. 49

5- $\quad$ Resultados e discussões

5.1- Perdas de massa por degradação

pág. 51

5.2- Pré-análise do problema por simulação pág. 52

5.3- Rasgos de pó e refrigeração pág. 62

5.4- Primeira bateria de testes pino-disco pág. 65

5.5- Segunda bateria de testes pino-disco pág. 71

5.6- Estimativa das temperaturas na face pág. 76

5.7- Avaliação dos coeficientes de atrito obtidos nos ensaios pág. 80

5.8- Extrapolação dos resultados dos ensaios pino-disco 
6- Conclusão

pág. 85

7- Referências

pág. 88

Anexo A - Fotos das lonas primeira bateria de ensaios

pág. 92

Anexo B - Fotos dos contra-corpos primeira bateria de Ensaios

pág. 97

Anexo C - Fotos dos corpos-de-prova segunda bateria de ensaios

pág. 101

Anexo D - Fotos de lonas desgastadas embreagem de prensa

pág. 115 


\section{1- INTRODUÇÃO}

Existe uma grande gama de aplicações industriais de freios e embreagens. Desde pequenos limitadores de torque até grandes freios para guinchos de tensão constante em plataformas. Uma das aplicações mais usuais é em prensas mecânicas.

A grande diferença entre o freio e/ou embreagem industrial, principalmente em prensas ante o uso automobilístico e ferroviário é o regime de trabalho. Há aplicações em prensas, destacadamente as de forjamento de matriz fechada onde o tempo de ciclo de embreamento (operação - frenagem - alimentação) pode ficar em torno de $2 \mathrm{~s}$. Ocorrendo tal tempo entre a transferência da pré-forma para a forma.

O problema de aquecimento e dissipação de calor é então um fator primordial para um bom desempenho do equipamento quanto à manutenção de sua capacidade de embreamento, frenagem e durabilidade.

O desgaste dos materiais de atrito é importante por dois motivos principais:

- O custo de uma troca de lonas em função do tamanho e dificuldades de operação.

- O custo de uma máquina parada, em função da redução de produção.

Em manutenções foram notados dois tipos de coloração e consistência nos resíduos de desgaste ("debris"). Um avermelhado e áspero lembrando apenas um abrasivo e outro preto e liso lembrando um pó de grafita, figuras 1.1 e 1.2.

Isto sugere dois regimes de desgaste no material de atrito.

O pressuposto é que o resíduo avermelhado corresponde a um desgaste moderado e o resíduo preto corresponde a um desgaste severo, e associar esses regimes com velocidade, pressão de contato e principalmente com temperatura de trabalho e degradação da base polimérica do compósito.

A literatura existente é voltada principalmente ao uso veicular, onde o problema de aquecimento é descrito. Porém o tempo de resfriamento e o espaçamento de aplicações do freio ou embreagem são bem superiores. Pressões de contato usuais nessas aplicações não são aplicáveis a prensas com ciclos curtos de embreamento. Um melhor entendimento desse fenômeno permitirá no futuro obterem-se parâmetros que auxiliem o projeto desses equipamentos e possíveis soluções paliativas em equipamentos existentes. 


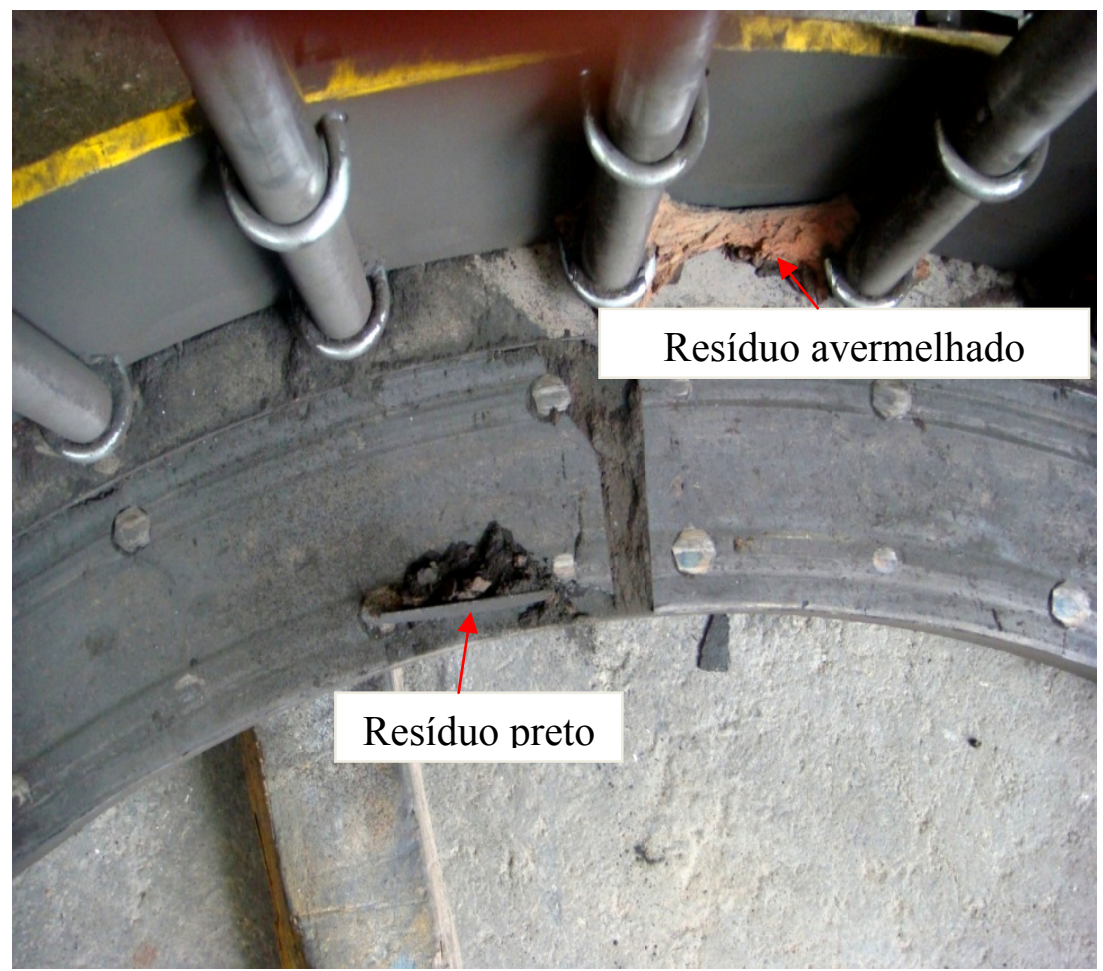

Figura 1.1: Resíduos de uma embreagem

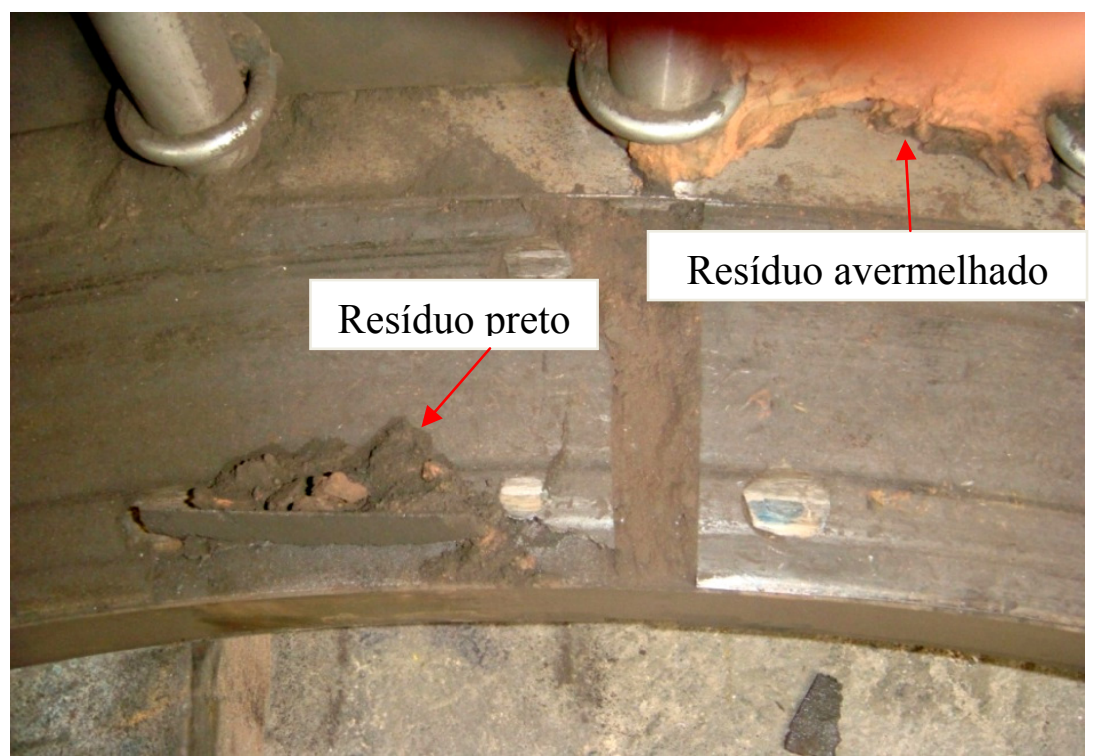

Figura 1.2: Ampliação da figura 1.1

Soman (1984) comenta a manutenção de embreagens em prensas, limites de desgaste e mostra a sua importância. 
Para a empresa operadora da máquina, pode ser um maior custo inicial ou um maior investimento nos materiais de atrito nas manutenções são economicamente vantajosos, como mostra o exemplo seguinte:

Um conjunto de freio embreagem de $150.000 \mathrm{~N}$ x m, composto de duas lamelas de embreamento e uma lamela de frenagem (cada lamela com elementos de atrito em ambos os lados).

a- Troca de lonas por lamela:

- Material: R\$3.000,00

- Mão de Obra: R\$1.500,00

b- Total por conjunto: $\mathrm{R} \$ 13.500,00$ (3 lamelas).

C- Montagem, desmontagem, empilhadeira, transporte: R\$ 4500,00.

d- Valor do serviço executado por terceiros: $R \$ 25.000,00$ a $R \$ 30.000,00$.

Considerando-se a média atual de 6 meses entre trocas um custo anual de cerca de $\mathrm{R} \$ 50.000,00$. Imaginando-se usar um material melhor com vida de 2 anos, mas com o dobro do custo (mais $R \$ 9.000,00$ ), o custo anual ficaria em $R \$ 18.000,00$ com uma economia de $\mathrm{R} \$ 32.000,00 /$ ano.

Outro custo importante, talvez o maior, é o relacionado à perda de produção que varia de empresa a empresa, constituído basicamente em diminuição do lucro, mãode-obra parada, etc. Como exemplo, toma-se uma peça de valor de venda unitário de $R \$ 12,00$, com lucro de $R \$ 3,00$, e uma produção de 6 peças por minuto e uma eficiência no processo de $80 \%$. Uma parada causaria uma diminuição de lucro de $\mathrm{R} \$$ $864,00 / \mathrm{h}$, sendo a parada estimada em $150 \mathrm{~h}$ a perda na parada seria algo em torno de $R \$ 129.600,00$. Com duas paradas anuais seriam $R \$ 260.000,00$ de perdas, com meia parada anual $\mathrm{R} \$ 65.000,00$. Portanto a opção de uma parada anual resulta em uma diminuição das perdas em $\mathrm{R} \$ 195.000,00$.

A economia total anual seria de cerca de $R \$ 227.000,00$, o que justifica plenamente investimentos em melhores materiais, permitindo uso de plásticos de engenharia como resinas e fibras caras como aramidas e fibra carbono. Os fabricantes hoje timidamente começam a disponibilizar melhores materiais.

A alternativa a materiais melhores é a utilização de um melhor dimensionamento da embreagem para se obter resultados econômicos semelhantes aos mostrados acima. Uma menor pressão de contato e uma maior área de contato podem 
aumentar significativamente a vida da embreagem ou do freio, com apenas um pequeno acréscimo no custo inicial.

Em vários pontos desse trabalho utilizam-se dados, imagens e gráficos de relatórios de projeto e manutenção de divulgação restrita listados abaixo:

BUIJK, A., PRITZELWITZ, P. V. Forging of part G-661, with pre form optimization. Simufact Americas LLC. 2008. (Relatório Iperfor).

PRITZELWITZ, P. V. Prensas conceitos básicos: curso treinamento. Hortolândia, Bosch Continental, 2008.

PRITZELWITZ, P. V. Projeto PCP2-600 (prensa mecânica para repuxo de 600 t), São Paulo. Prensas Gutmann, 1998.

PRITZELWITZ, P. V. Manutenção embreagem UC 1000 (prensa mecânica forja de 1000 t). São Paulo, Prensas Luxor, 2008.

PRITZELWITZ, P. V. Projeto Futura 65, 85 e 130 (prensas mecânicas tipo C de 65, 85 e 140 t). São Paulo, Prensas Luxor, 2007.

PRITZELWITZ, P. V. Projeto HB 40 (prensa mecânica rápida de 40 t). São Paulo, Prensas Luxor, 2003.

PRITZELWITZ, P. V. Projeto PTFE-95 (prensa mecânica tipo C de 95 t). São Paulo, Prensas Gutmann, 1999.

PRITZELWITZ, P. V. Projeto SC1 400 (prensa mecânica para corte de 400 t). São Paulo, Prensas Luxor, 1998.

PRITZELWITZ, P. V. Projeto UC 1000 (prensa mecânica de forja de 1000 t). São Paulo, Prensas Luxor, 2006.

PRITZELWITZ, P. V. Projeto UC 1600 (prensa mecânica de forja de 1600 t). São Paulo, Prensas Luxor, 2008. 


\section{2- REVISÃO BIBLIOGRÁFICA}

\section{1- PRENSAS.}

A utilização de prensas é ampla no mundo atual, desde pequenas prensas de uso doméstico até prensas de porte gigantesco como na figura 2.1, a prensa Mesta de $50.000 \mathrm{t}$ (ASME, 1961)

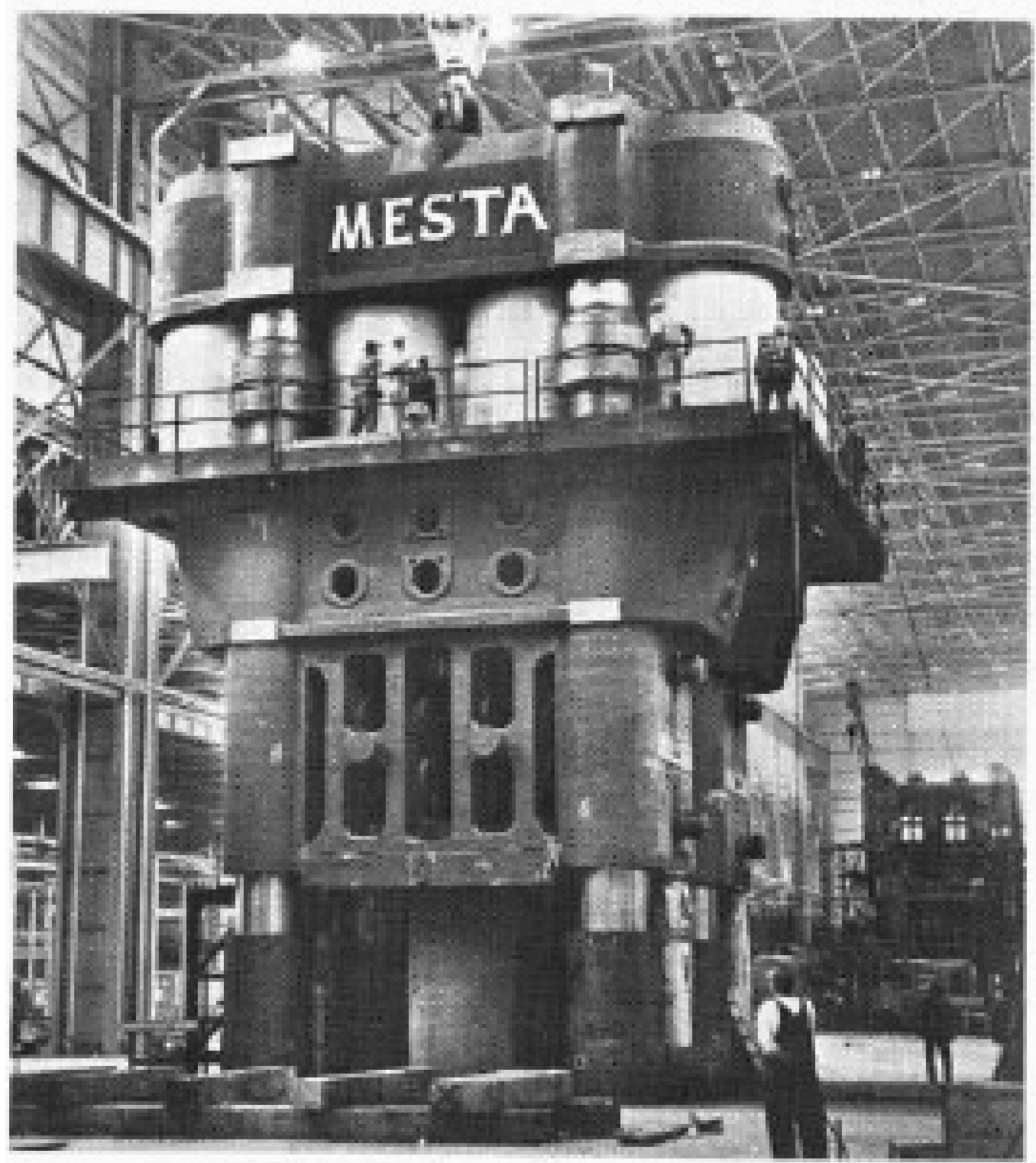

Figura 2.1: Prensa Mesta de 50.000 t (ASME, 1961).

Prensas são utilizadas para os mais diversos fins: corte, dobra, repuxo, extrusão, calibragem, forjamento, vulcanização, cura de polímeros, sinterização, etc. 
Podem ser divididas em dois grandes grupos: mecânicas e hidráulicas (apesar de que em alguns casos existam soluções combinadas, prensas para sinterização e corte fino, por exemplo).

As prensas mecânicas são classificadas quanto à sua cinemática: excêntricas, de joelho, de joelho com dupla ação e freio fricção (Makelt 1968, Schuler 1998, Schuler 1966). As mais comuns são as excêntricas.

A prensa mecânica pode trabalhar de duas maneiras: regime contínuo e regime intermitente. O regime contínuo se dá em prensas com sistemas automáticos de alimentação, onde a cinemática é engatada juntamente com o sistema de alimentação, permanecendo um longo período engatado. O regime intermitente se dá quando a máquina é parada para alimentação e descarga, engata-se a máquina, faz-se a operação, freia-se a máquina e assim por diante. O processo de alimentação pode ser manual ou robotizado. Um dos mais severos regimes é o das prensas de forja, a quente, em matriz fechada. Essas prensas caracterizam-se por uma alta velocidade de até 120 golpes por minuto, minimizando o tempo de contato peça-matriz e grandes capacidades de 600 t até 8000 t. Outro ponto a ser destacado é o pequeno tempo entre operações, principalmente entre pré-forma e forma. Nessas prensas o projeto do sistema de freio e embreagem é crítico. Na figura 2.2 mostra uma prensa de matriz fechada de $1000 \mathrm{t}$ com um conjunto combinado de freio-fricção no eixo motor e na figura 2.3 (Rovetta-Manzoni) outra prensa de matriz fechada de $2500 \mathrm{t}$ com freio e fricção no eixo excêntrico.

Nas operações de forjamento existem outras máquinas nas quais o sistema de freio e embreagem também é solicitado a extremo; rolos de laminação ("forging rolls") e prensas horizontais ("upsetters").

As principais características de uma prensa excêntrica são: dimensões da mesa, abertura no PMI (ponto morto inferior) e regulagem de altura do martelo quanto à ferramenta a ser usada e peça a ser produzida. De outro lado, são importantes curso, velocidade (GPM), força nominal e altura do PMI. A altura do PMI e a força nominal determinam o trabalho máximo disponível pela prensa. 


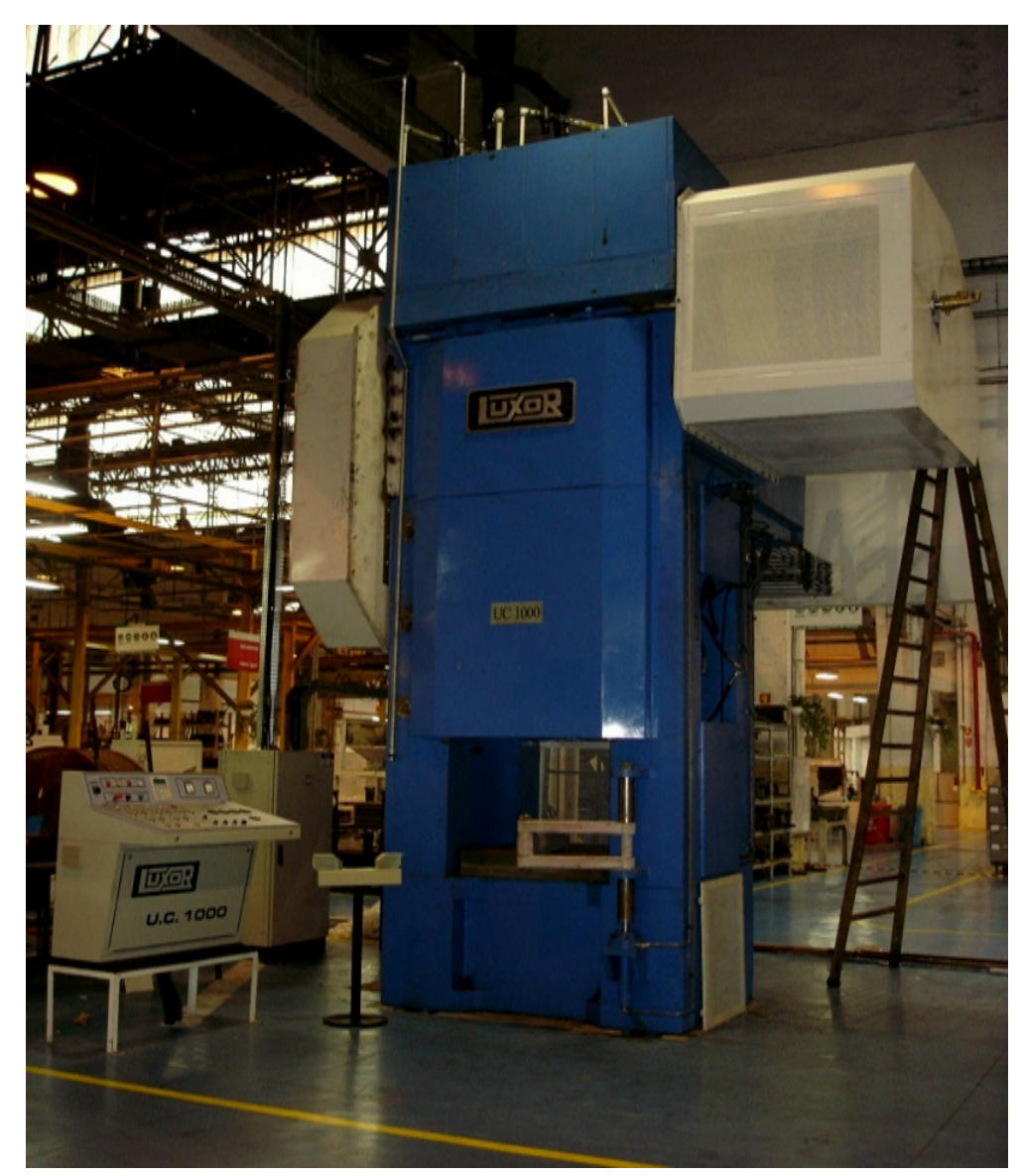

Figura 2.2: Prensa de $1000 \mathrm{t}$ (UC 1000)

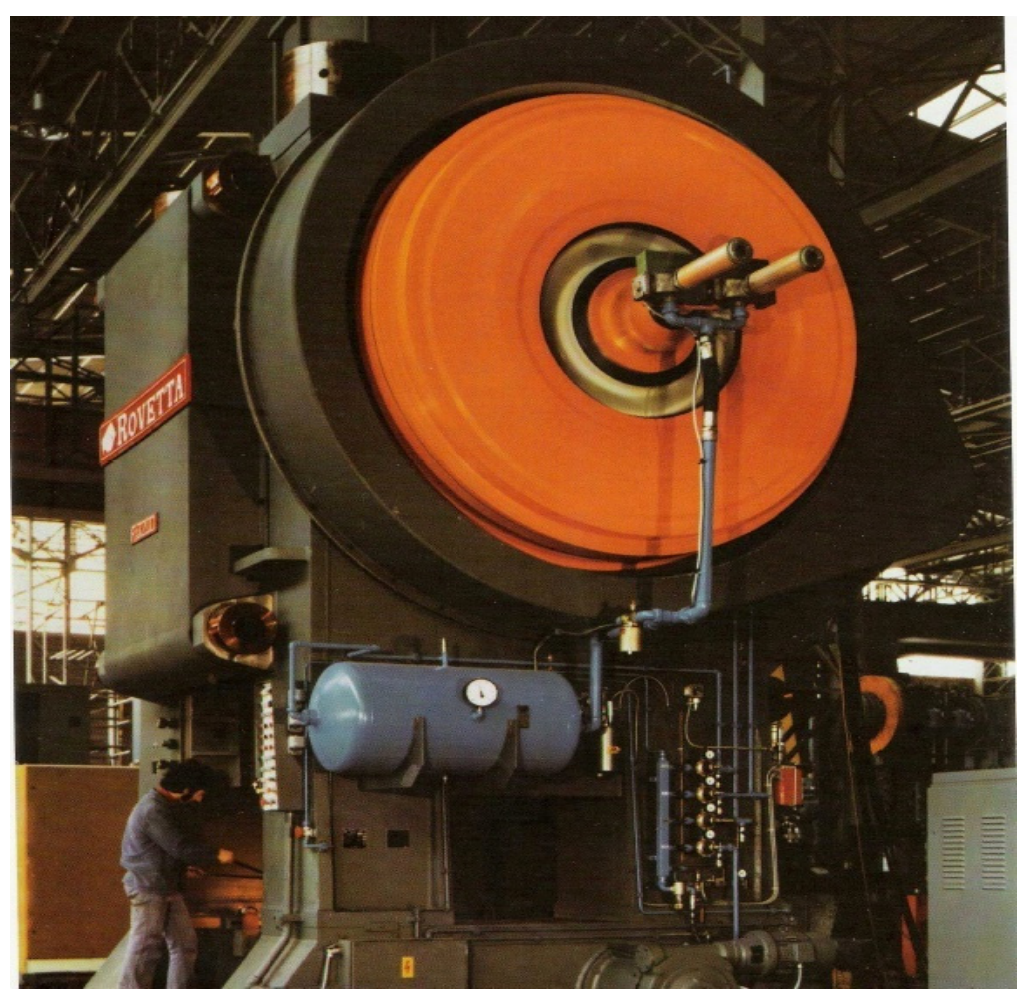

Figura 2.3: Prensa de $2500 \mathrm{t}$ (Rovetta-Manzoni). 
A figura 2.4 mostra a sequência do projeto de onde temos três grandes grupos: o projeto de prensa segundo suas especificações, onde se define a cinemática e os principais torques, a seleção da lona dentro da disponibilidade de materiais comerciais, o processo iterativo do dimensionamento da embreagem que deve atender aos torques requeridos e o que é importante neste tipo de máquina as condições de aquecimento da embreagem.

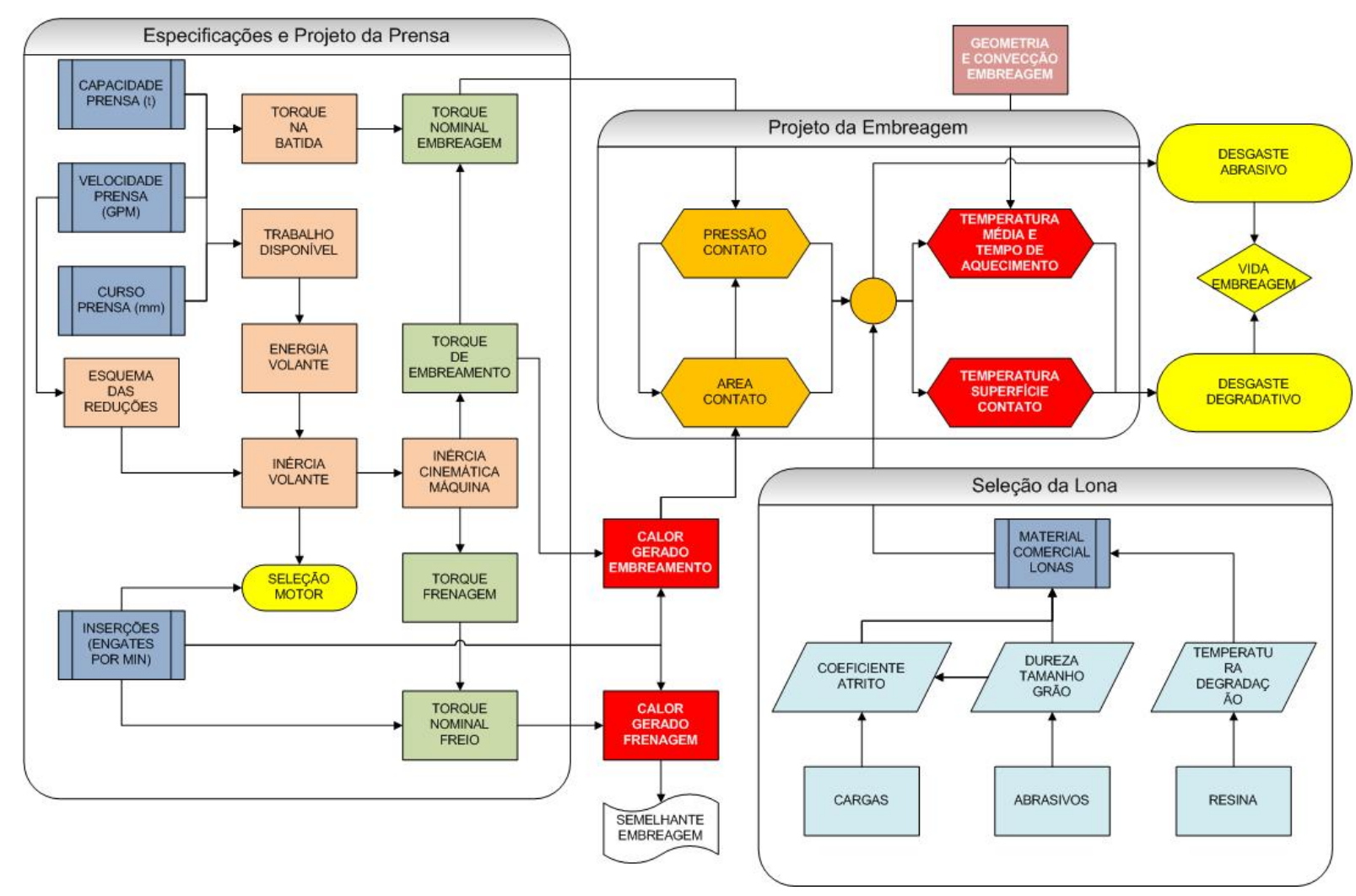

Figura 2.4: Fluxograma de projeto cinemática de prensa mecânica. 


\section{2 - FREIOS E EMBREAGENS EM PRENSAS}

Em prensas mecânicas, como exposto anteriormente, a embreagem é dos seus componentes fundamentais na cinemática da máquina.

O tipo mais usual é o do freio e embreagem combinado. A preferência de sua utilização se dá por ser uma unidade compacta, de fácil instalação e por ter uma pneumática simples (apenas uma válvula de dupla segurança - PPRPS).

As figuras 2.5 e 2.6, (Projeto UC 1000) que mostram uma embreagem combinada para um torque de $150.000 \mathrm{~N}$ x m. São chavetadas ao eixo, normalmente ao eixo de maior rotação ou em alguns casos ao eixo excêntrico. As molas pressionam o atuador contra a pista de frenagem, comprimindo as lonas de freio, mantendo o conjunto freado (isso é um requisito de segurança, a frenagem independe do suprimento de ar). Ao injetar ar na câmara de ar o atuador se move, vencendo a força das molas, em direção à pista de embreamento, comprimindo as lonas de embreamento. As lonas são montadas em suportes bipartidos para facilitar a sua montagem. A fixação das lonas nos suporte pode ser feita por meio de adesivo ou rebites (alguns casos ambos). As carcaças e o atuador são normalmente feitos de ferro fundido nodular, o cubo e guias normalmente em aço. Nessa embreagem as guias são em aço temperado, porém também se usa dentes ("splines") como guia ou sistemas combinados.

O ar da câmara é injetado por furos no eixo que tem em sua ponta uma união rotativa. O sistema pneumático consiste em uma alimentação de ar de 4 a 6,5 bar, tratamento de ar com filtro e válvula redutora de pressão, um pulmão de ar com retenção na entrada, válvula de alívio e pressostato. Na saída do pulmão temos o lubrificador (seu posicionamento após o pulmão visa a evitar o arraste de óleo que pode bloquear a válvula de segurança). Após o pulmão temos a válvula dupla de segurança fig. 2.7 (Ross Controls DM2).

A refrigeração da embreagem, fig. 2.8 (Projeto UC 1000), é feita por ar. Nas carcaças externas existem aletas para facilitar a troca térmica e o atuador trabalha como um ventilador insuflando ar. Como se pode ver na fig. 2.8 a parte mais refrigerada é o lado da embreagem. Por isso, em alguns conjuntos se opta por freio refrigerado a água. 


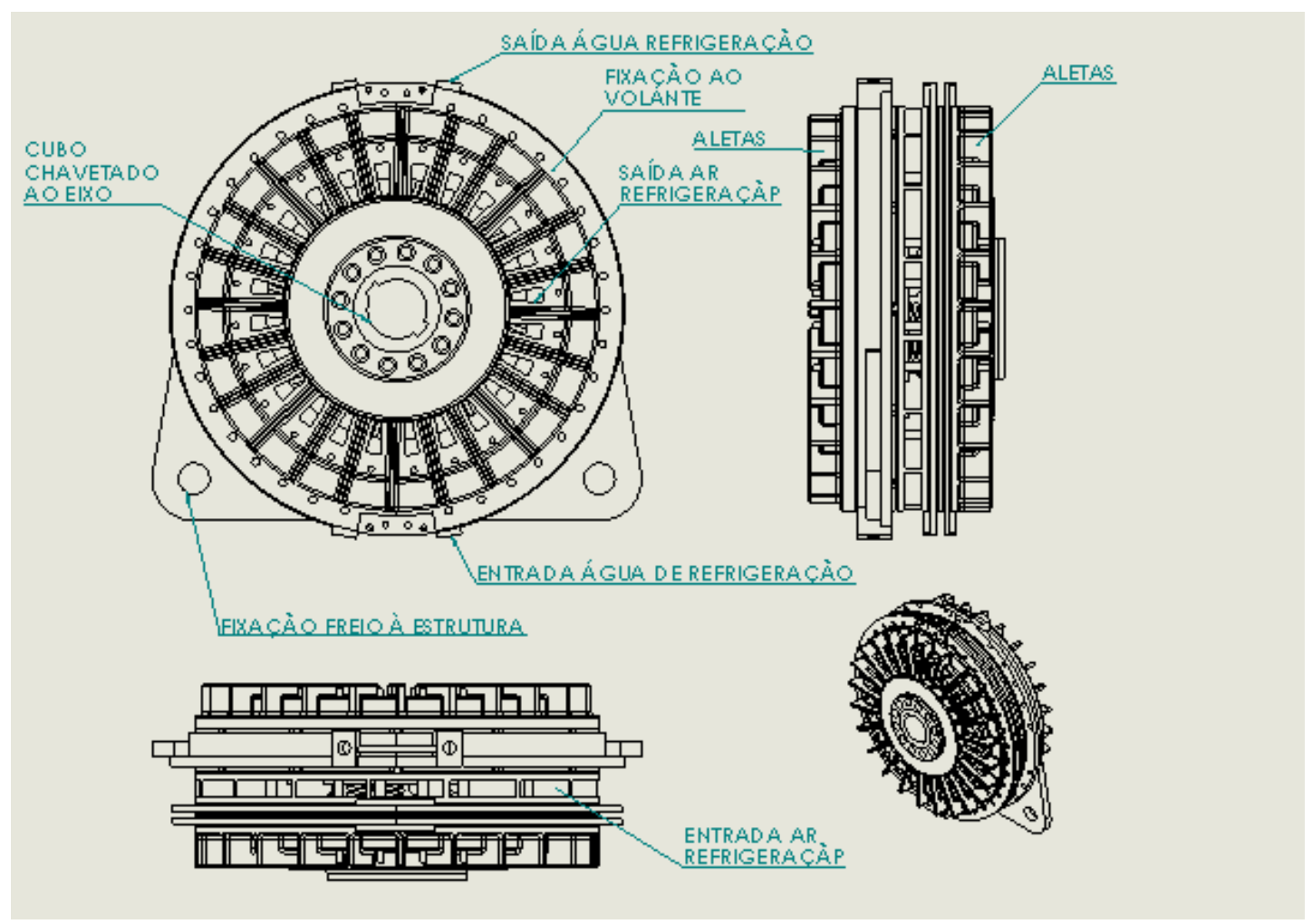

Figura 2.5: Embreagem 150.000 N x m (Projeto UC 1000).

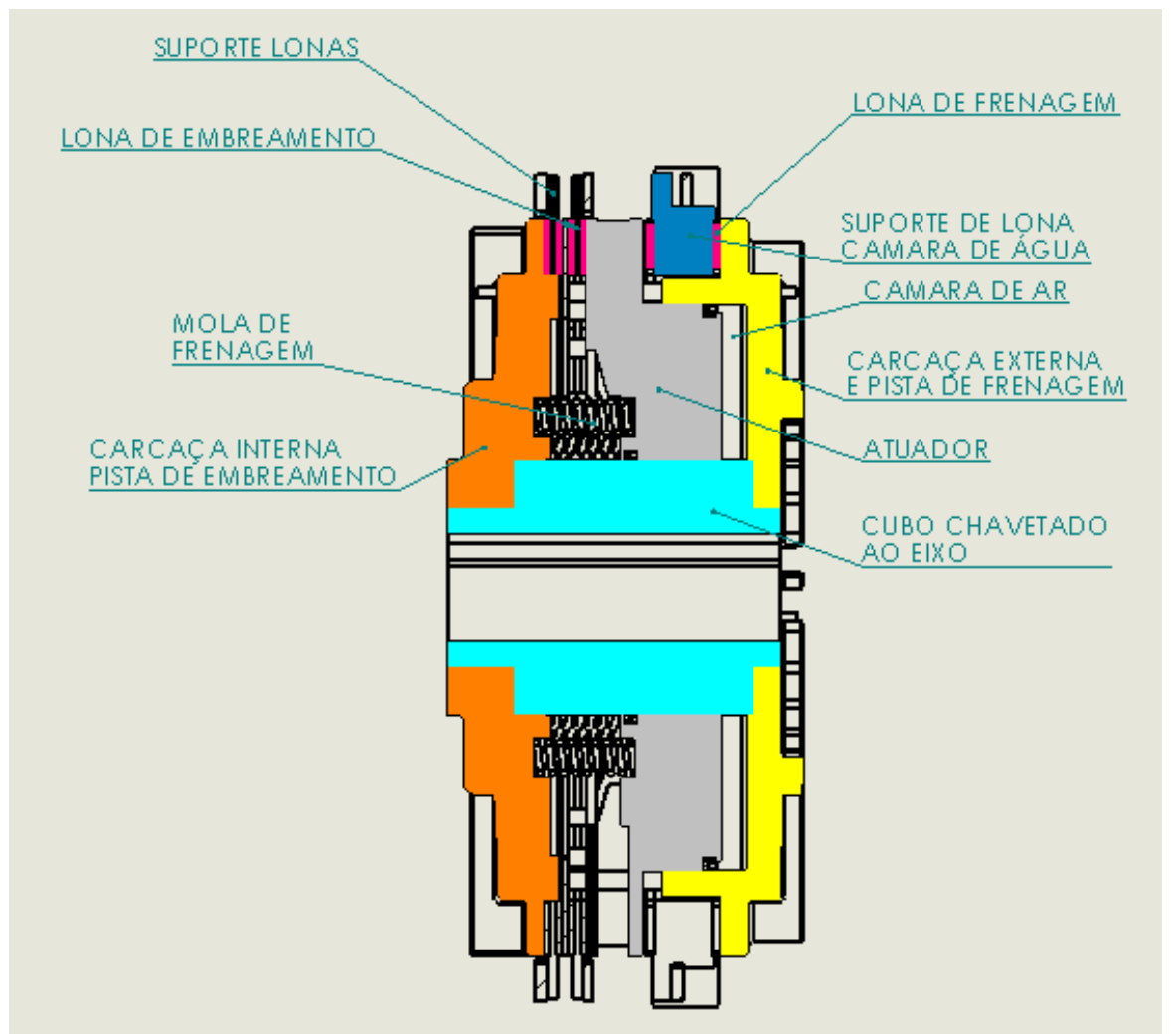

Figura 2.6: Embreagem $150.000 \mathrm{~N}$ x m, corte ilustrativo (Projeto UC 1000). 


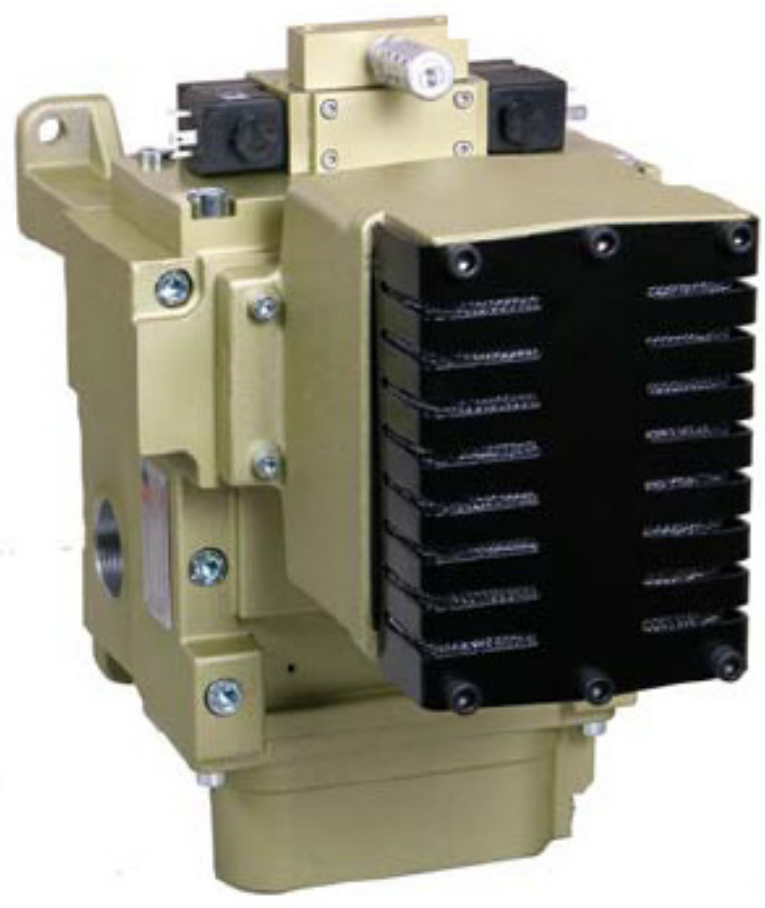

Figura 2.7: Válvula de dupla segurança conforme PPRPS (Ross Controls DM2).

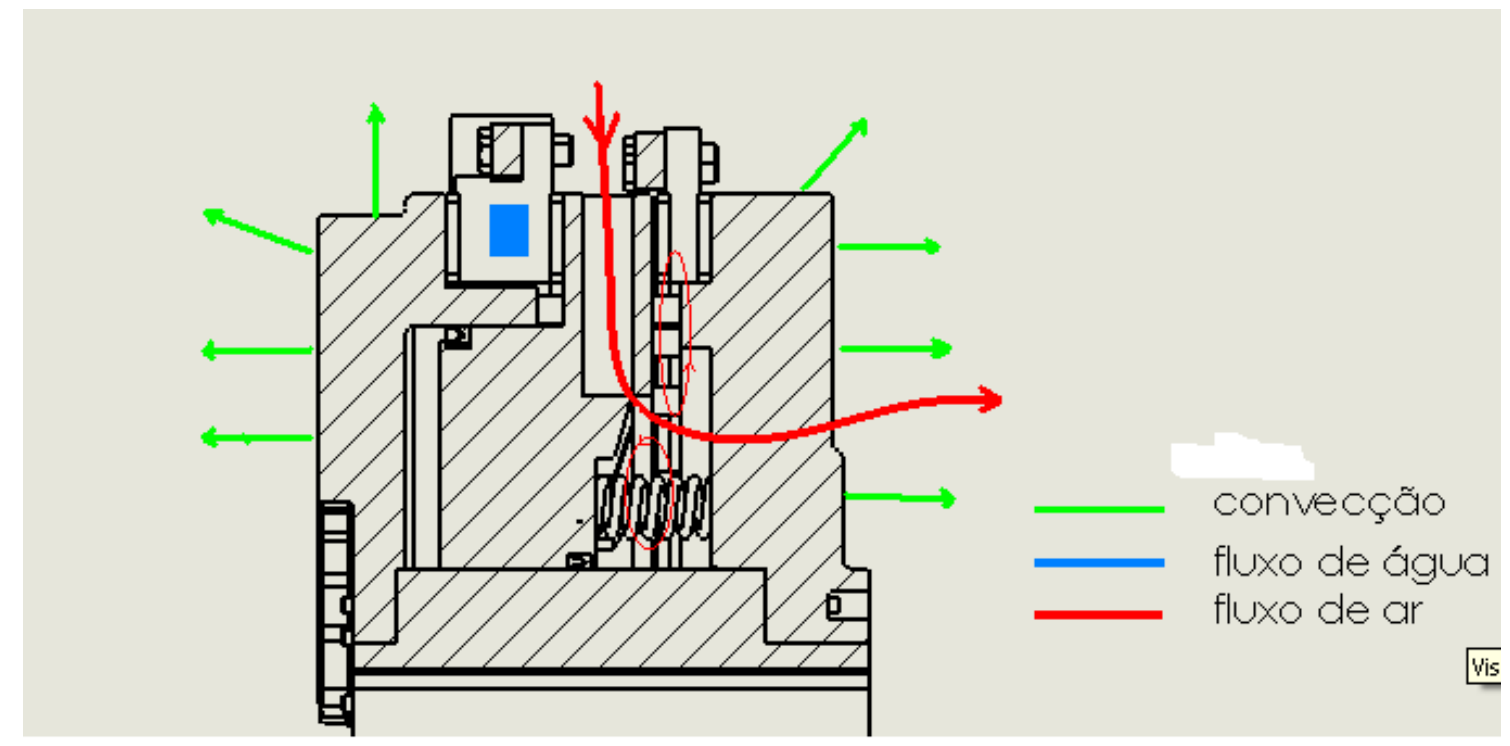

Figura 2.8: Fluxo esquemático troca de calor (Projeto UC 1000).

Em prensas maiores opta-se por freios e embreagens individuais, o que permite uma maior flexibilidade de arranjo. Porém o sistema pneumático mais complexo, por exigir o inter travamento dos dois sistemas pneumáticos. Seu funcionamento é 
similar ao descrito nos conjuntos combinados, e um exemplo está mostrado nas fig. 2.9 e fig. 2.10 (Projeto UC 1600). Em prensas de simples redução a embreagem é normalmente instalada na coroa (que trabalha como volante também) e nas de dupla redução, como o engrenamento é montado internamente ao cabeçote, temos o volante externo à máquina, onde é fixada a embreagem.

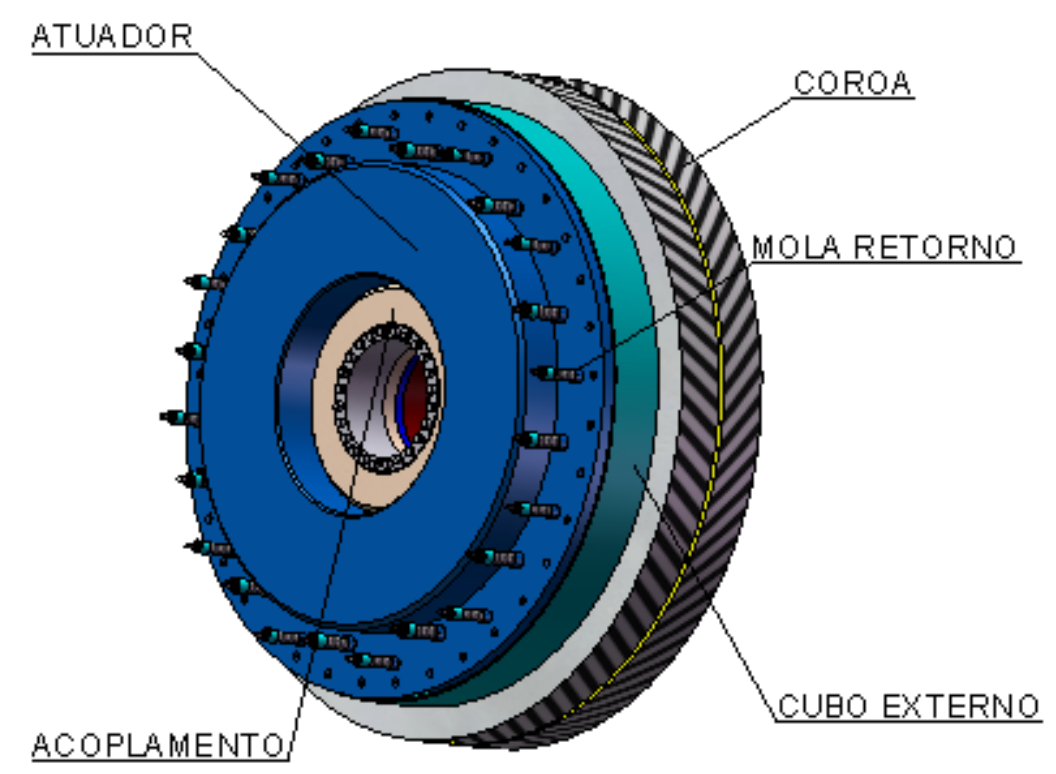

Figura 2.9: Embreagem $980.000 \mathrm{~N} x \mathrm{~m}$ (Projeto UC 1600).

Usam-se também embreagens hidráulicas, que, ao invés de se ter um atuador pneumático tem-se um atuador hidráulico. São normalmente a banho de óleo, que circula sob pressão para a refrigeração da mesma. As mesmas possuem múltiplas lamelas de material sinterizado (como nos conversores de torque). São muito compactas, com grande intervalo de manutenção. Sua grande vantagem é sua pequena inércia que permite acoplamento suave, porém firme. Suas desvantagens são o alto custo inicial, manutenção cara (apesar de remota) e problemas de vedação na união rotativa em função das altas pressões de fluído. 


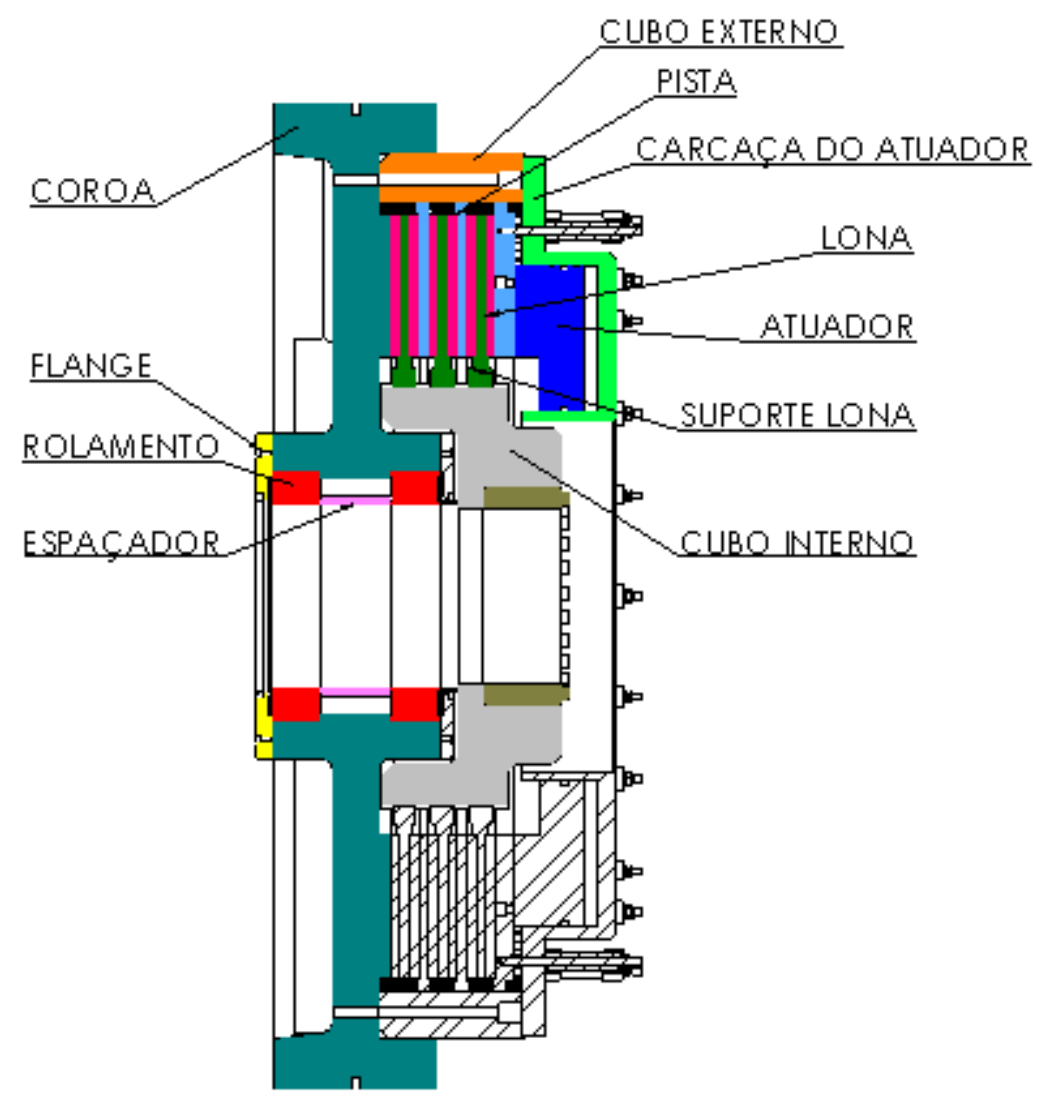

Figura 2.10: Embreagem 980.000 N x m, corte ilustrativo (Projeto UC 1600).

A grande diferença entre freios e embreagens automotivos (ou ferroviários) com os utilizados em prensas se dá em função de seu número de atuações (ou inserções). Um freio automotivo pode sofrer uma grande solicitação, aquecer, porém tem tempo para seu resfriamento. Porém uma embreagem com inserções com intervalos de $2 \mathrm{~s}$ seu tempo de resfriamento é curto, obrigando o polímero da base do compósito trabalhar a altas temperaturas. Na literatura não há de nosso conhecimento nenhum trabalho específico sobre embreagens de prensas mecânicas e nos manuais dos fabricantes de máquinas e embreagens (Ortlinghaus (2006) e Goizper (2006)), há valores práticos e limitações de uso. Existem várias máquinas com problemas de desgaste prematuro, aumentando o problema. A corrida para a produtividade obriga as máquinas a trabalharem com ciclos cada vez menores. Máquinas cujo processo permite baixas velocidades podem trabalhar em contínuo. Porém, com velocidades acima de 30 GPM (golpes por minuto) a operação em contínuo é inviável pelas limitações dos sistemas de transferência ("transfer") quanto à velocidade, obrigando as máquinas a trabalharem no sistema intermitente (embreamento, batida, frenagem e transferência). 
Shigley (1986) define a energia absorvida em cada embreamento como:

$$
E=I_{1} \times I_{2}\left(\omega_{1}-\omega_{2}\right)^{2} /\left(2 \times\left(I_{1}+I_{2}\right)\right)
$$

Onde:

$\mathrm{I}_{1}$ e $\mathrm{I}_{2}$ são as inércias relativas ao eixo de rotação.

$\omega_{1}$ e $\omega_{2}$ são as velocidades angulares antes e depois do acionamento.

O catálogo DESCH (2006) mostra simulações térmicas de suas embreagens. De maneira semelhante foi simulada a troca térmica em uma embreagem Airflex (1997), fig. 2.11 (v. Pritzelwitz 2008). O estudo foi para regime permanente, com inserções a $5 \mathrm{~s}$ cada, onde nota-se as temperaturas acima de $200{ }^{\circ} \mathrm{C}$.

No Projeto UC 1600 foi dimensionada uma embreagem de $980.000 \mathrm{~N} \mathrm{x} \mathrm{m} \mathrm{para} \mathrm{uma}$ prensa de forja de $2000 \mathrm{t}$. As áreas de contato foram sendo gradativamente aumentadas até se conseguir temperaturas abaixo de $200{ }^{\circ} \mathrm{C}$ (fig. 2.12), na área mais quente (lamelas internas); o ciclo de operação era de $2 \mathrm{~s}$. Como se vê existem seis faces em contato (três lamelas). O diâmetro externo é de 2000 mm, com uma área de $11,4 \mathrm{~m}^{2}$ de contato e uma pressão específica de $78 \mathrm{kPa}$. É uma embreagem muito grande e com muito baixa pressão de contato, aumentando a área de contato com intuito de minimizar a temperatura de operação. Na fig. 2.13 temos a curva de aquecimento do conjunto obtida também por análise de elementos finitos.

Os catálogos da Carlslile (2005) e Trimat (2006) apresentam uma redução do coeficiente de atrito em função da temperatura, então para projeto deve-se usar o coeficiente de atrito corrigido.

Outro ponto importante no projeto, principalmente no caso de freios e embreagens combinadas que a força de frenagem e embreamento dependem da compressão das molas. Em freios as molas estão comprimidas para aplicarem uma força normal necessária, com o desgaste essa pré-compressão das molas diminui, e a força normal também. $O$ ponto de projeto será então com o máximo desgaste das lonas e verificando-se se com lonas novas a pressão exercida está dentro do máximo aceitável da lona. Nos conjuntos combinados além desse problema têm se que a força normal de embreamento é a força do atuador menos as das molas, com as lonas de embreamento gastas o curso é maior. Isso implica num dimensionamento correto da área do atuador. 
estudo preliminar freio5-998:: Thermal Time step : 1

Units: Celsius

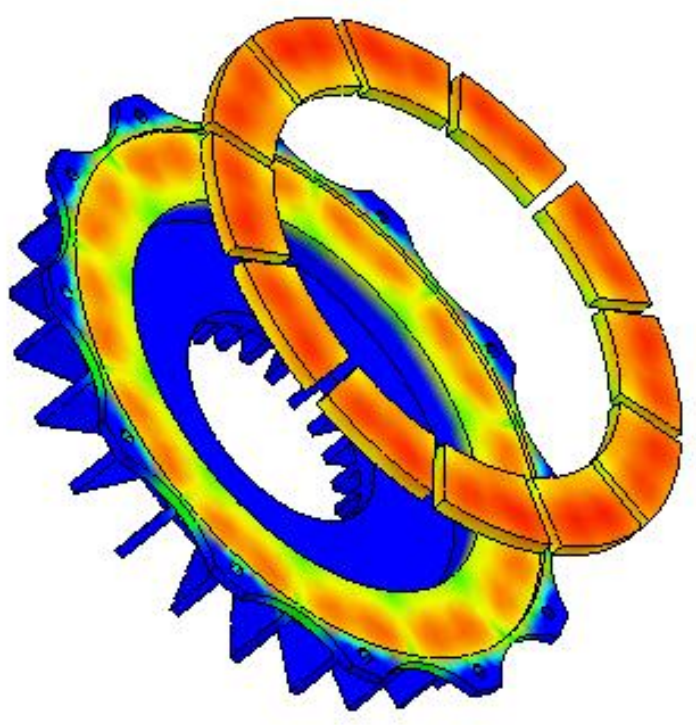

Temp

$2.200 \mathrm{e}+002$

$2.175 \mathrm{e}+002$

$2.150 e+002$

$2.125 \mathrm{e}+002$

$2.100 \mathrm{e}+002$

$2.075 \mathrm{e}+002$

$2.050 \mathrm{e}+002$

$2.025 \mathrm{e}+002$

$2.000 \mathrm{e}+002$

$1.975 e+002$

$1.950 \mathrm{e}+002$

$.925 \mathrm{e}+002$

$1.900 \mathrm{e}+002$

Figura 2.11: Análise térmica embreagem Airflex (v. Pritzelwitz 2008).

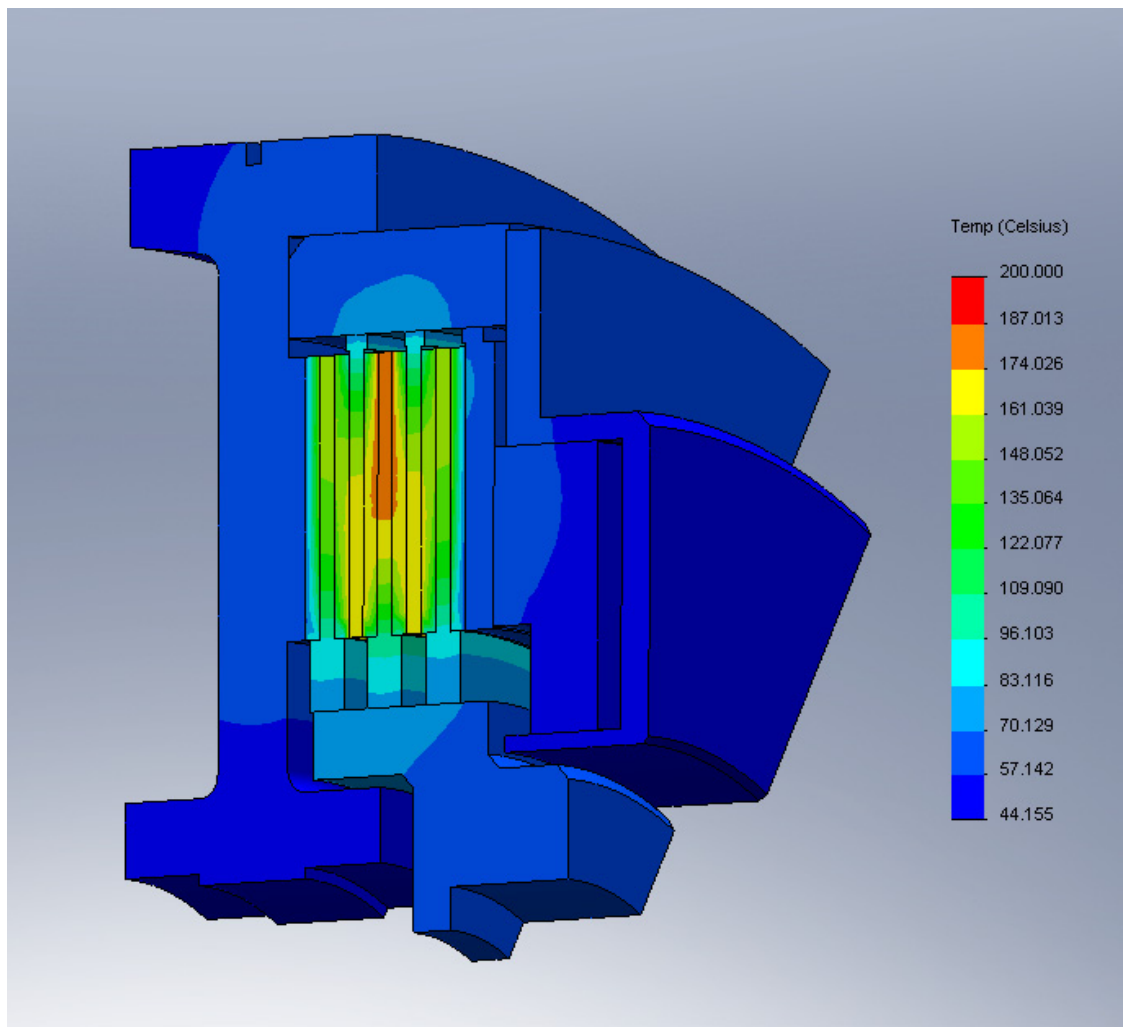

Figura 2.12: Análise térmica embreagem $980.000 \mathrm{~N} \mathrm{x} \mathrm{m} \mathrm{(Projeto} \mathrm{UC} \mathrm{1600).}$ 


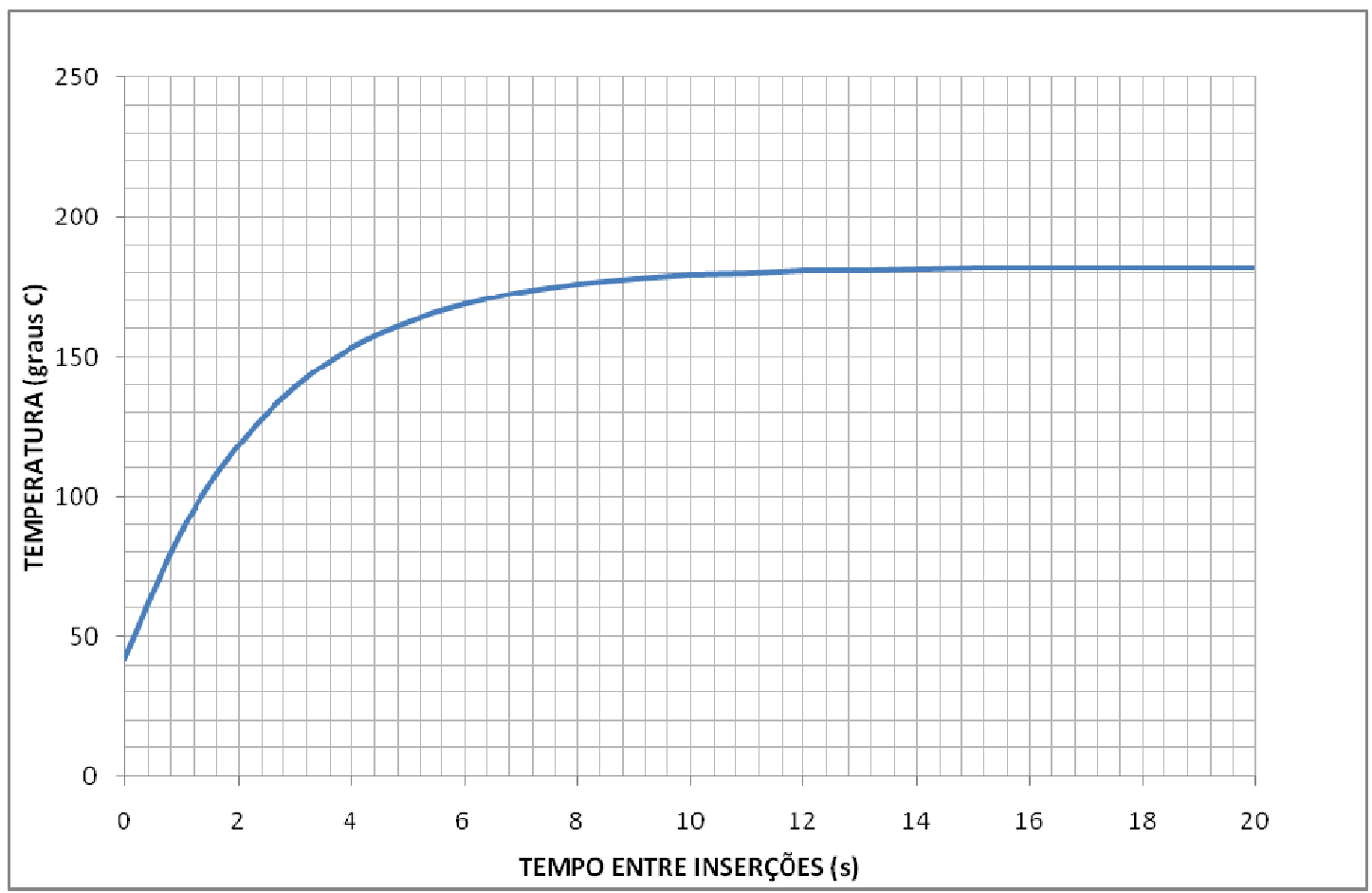

Figura 2.13: Curva de aquecimento da embreagem de $980.000 \mathrm{~N}$ x m (Projeto UC 1600). 


\section{3. - CONSTRUÇÃO DE LONAS E TIPOS DE MATERIAIS}

O contato de freios e embreagens se faz por meio das lonas que são os materiais de atrito.

Blau (2001) apresenta uma cronologia do desenvolvimento de materiais para freios:

a- $\quad$ Até 1870: ferro fundido ou aço, uso ferroviário ou em automotivo.

b- $\quad$ 1897: correias de algodão ou pêlo para freios de automóveis e vagões.

c- $\quad$ 1908: lã de asbestos com latão e outros arames para carros e caminhões

d- 1926: revestimentos moldados de carvão betuminoso com fibras curtas de crisólito (asbestos) e partículas de latão.

e- 1930: materiais moldados para substituíram os blocos de ferro fundido no metro de Londres

f- $\quad$ 1930: resinas flexíveis de maior complexidade em lonas de freios.

g- 1950: revestimentos metálicos em base de resina, uso em aviões e indústrias.

h- 1960: fibra de vidro, metálicas, carbono e sintéticas em substituição ao asbesto e com melhor desempenho, uso veicular.

i- $\quad$ 1980: Materiais livres de asbestos (substituído pela fibra de vidro) em lonas de tambores de freio veiculares.

j- $\quad$ 1991: Sugestão de uso de fibra de carbono em aplicações automotivas.

Nos livros clássicos de Elementos de Máquinas, por exemplo: Carvill (2003), Collins (2006), Faires (1975), Mott (1992), Niemann (1971), Norton (1998), Shigley (1984), Spotts (1998) e Stolarski (2000), pouco se fala do modo construtivo e materiais usados em lonas de freio e embreagem. Esses autores citam basicamente os principais materiais como couro, madeira, moldados, asbestos e sinterizados dando faixas de coeficiente de atrito, temperaturas máximas e pressões máximas. Há alguns anos a utilização de asbesto era comum em lonas de freio e embreagem. Porém, por serem cancerígenos, seu uso foi banido na maioria dos países. Apenas alguns países ainda produzem materiais com asbestos, ex: Índia e Rússia.

Nos trabalhos de Linch (1968), Ganguly (2007), Blau (2001) e Wright (2007) têm se uma idéia geral sobre os asbestos, sua decomposição e seus efeitos à saúde. A exclusão do asbesto viabilizou uma nova gama de materiais em freios e embreagens como as fibras de vidro, fibras celulósicas, aramidas e fibras de carbono. 
Basicamente as lonas são compósitos, com uma matriz polimérica, reforçados com fibras e com adição de abrasivos para melhorar o coeficiente de atrito. Existem materiais sinterizados para utilização a seco e em banho, mas estão fora do escopo do trabalho. A tese de Rodrigues (2007) apresenta a figura 2.14 que mostra a fabricação de lonas de embreagem.

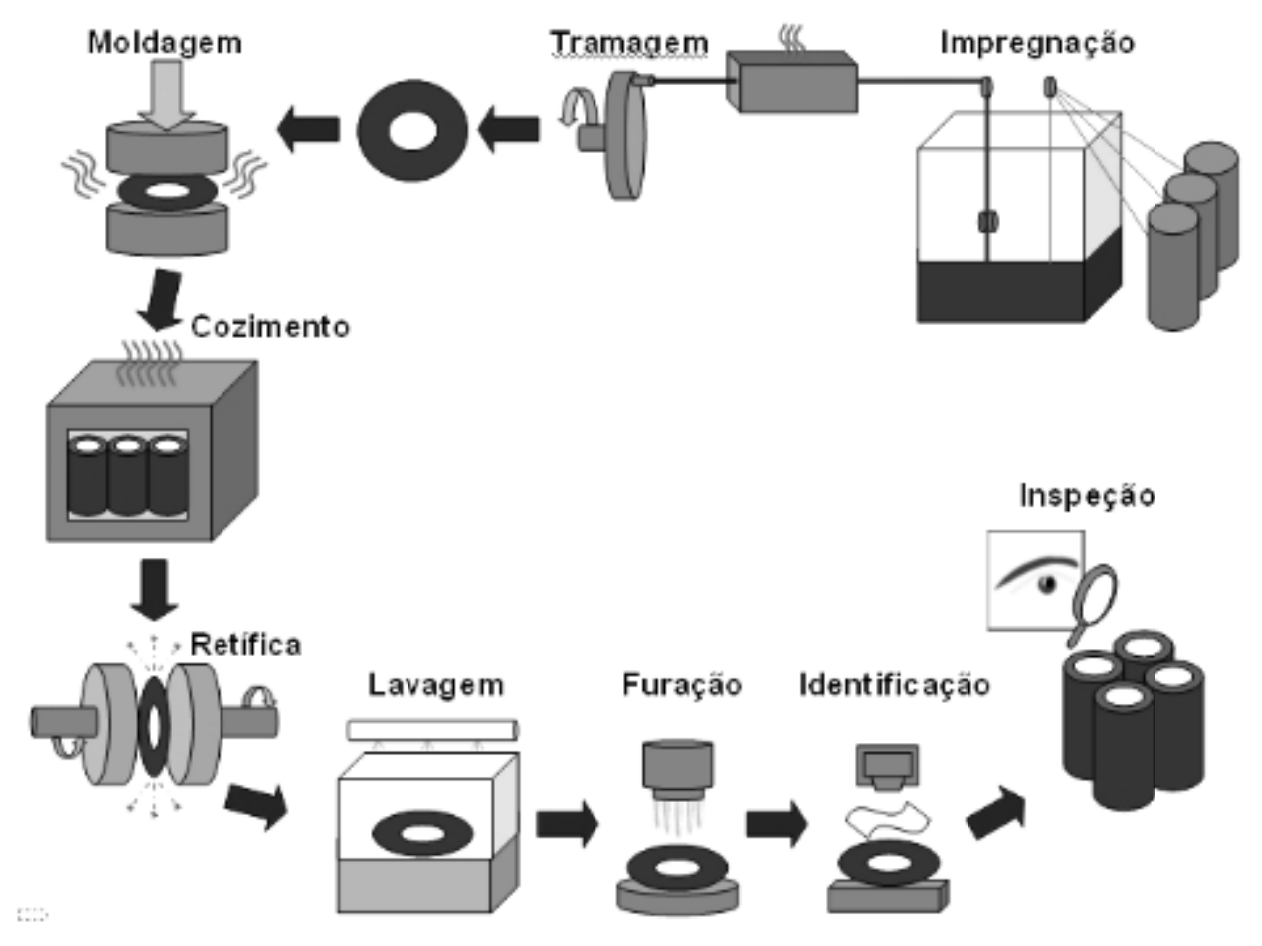

Figura 2.14: Processo produtivo de lonas de embreagem, Rodrigues (2007).

Esse é um processo para indústria automotiva, as lonas industriais são normalmente fornecidas em placas, a moldagem e o cozimento é comumente feito em uma prensa hidráulica com placas aquecidas ("plateaus").

Rodrigues define as matérias primas como matriz, fibras de reforço e carga (abrasivos, lubrificantes, modificadores de atrito e cargas de enchimento).

Pouco se acha na literatura sobre a composição das lonas, pois os mesmos são segredos industriais. Em uma das poucas exceções Stachoviak (2004) cita alguns exemplos donde se têm os seguintes valores: resina de 20 a 40\%, fibras de 10 a $30 \%$, abrasivos de 6 a 10\%. Nessa referência o autor dá como exemplo uma lona, onde temos $20 \%$ de resina fenólica, $10 \%$ de fibra aramida, $10 \%$ fibra de sílica alumina, $15 \%$ fibras de titanato de potássio, $5 \%$ de fibras de cobre, $3 \%$ de grafite, $15 \%$ de pó de caju, $5 \%$ de pó de borracha, $15 \%$ de sulfato de bário e $5 \%$ de zeolite. 


\subsection{1 - COMPÓSITOS}

Tipos de compósitos, processos de fabricação e propriedades mecânicas dos mesmos são assuntos achados amplamente na literatura e não há a necessidade de detalhar tais pontos.

Stachoviak (2000) faz uma interessante abordagem de compósitos e aspectos tribológicos relativos aos mesmos. Sendo importante sua afirmação: o coeficiente de atrito obedece a recíproca das leis das misturas.

$$
1 / \mu=V f / \mu f+V m / \mu m
$$

onde:

$\mu$ é o coeficiente de atrito;

$\checkmark$ é a fração do volume;

$\mathrm{f}, \mathrm{m}$ índices respectivamente relativos à fibra e a matriz.

\subsection{2 - ABRASIVOS}

Como de modo geral os polímeros e as fibras utilizadas também têm baixo coeficiente de atrito há a necessidade da adição de abrasivos ao compósito para aumentar o coeficiente de atrito. Em geral os abrasivos são colocados como carga no polímero.

Um conceito levantado por Spur (1972) é muito importante para o entendimento do problema: " $\mu$ is roughly proportional to Mohs hardness; too much mineral filler tends to wear the counter-face", $\mu$ é aproximadamente proporcional a dureza em Mohs, excesso de carga mineral tende a desgasta a contra face, o que indica que a dureza do abrasivo é que "define" o coeficiente de atrito.

Blau (2001) relaciona os tipos de abrasivos principais utilizados: óxido de alumínio, óxidos de ferro, quartzo $\left(\mathrm{SiO}_{2}\right.$ triturado), sílica (natural ou sintética), silicato de zircônio.

Stachoviak (2004) faz o seguinte comentário: Lonas de freio mostram um decréscimo na variação do coeficiente de atrito com o aumento do conteúdo de lubrificante (adição de grafita ou de sulfetos metálicos como carga). Lonas de freio mostram um acréscimo da variação do coeficiente de atrito com aumento do conteúdo de abrasivo. É importante então se encontrar o ponto de equilíbrio entre a quantidade de lubrificante e a quantidade de abrasivo. 
Nos materiais comerciais predominam os óxidos de ferro, a alumina e barita. Pouco se sabe sobre a composição exata de tais materiais nas lonas por ser um segredo industrial e sua divulgação ser extremamente restrita.

\subsection{3 - MATERIAL BASE - MATRIZ POLIMÉRICA}

Basicamente a matriz é um fenol formol como citado por Rodrigues (2007) e conforme Linch (1968) a sua porcentagem em massa varia de $28 \%$ a $48 \%$ da massa total da lona.

Blau (2001) cita como matrizes o fenol formol e "resinas modificadas" (plásticos de engenharia; PVB (polivinil butiral), PEEK (poliéteretercetona), etc.)

Bahadur (2003) cita também como matriz a resina fenólica.

Stachowiak (2004) cita como matrizes a resina fenólica, COPNA, resina fenólica modificada com silicone, estercianatos, resina fenólica modificada com epóxi e poliimida termoplástica.

Ganguly (2007) tem um estudo sobre a adição de resina de castanha de caju como modificador de atrito e agente melhorador da resistência térmica do fenol formol.

A tabela 2.1 relaciona alguns produtos comerciais e sua matriz polimérica, infelizmente os dados podem ser, mas os fabricantes não fornecem todos os dados também por uma questão de segredo industrial.

A invenção do baquelite em 1909 pelo Dr. Baekeland foi o início do uso de resinas fenólicas na indústria. Obtida pela combinação por polimerização de um fenol e um formaldeído sob calor e pressão. Existem várias indústrias fornecendo resinas fenólicas para diversos usos, entre eles a indústria de lonas para freios e/ou embreagens. A resina fenólica pode ser combinada com borrachas e silicones para uso em lonas.

As resinas fenólicas são complexas e as estruturas presentes vão depender da: razão fenol e formaldeído utilizada, do pH da reação, da temperatura da reação. 
Tabela 2.1: Materiais comerciais: resina e temperaturas de trabalho

\begin{tabular}{|c|c|c|c|c|}
\hline FABRICANTE & PRODUTO & MATRIZ POLIMÉR. & $\begin{array}{l}\text { TEMPERATURA } \\
\text { MAX. (graus C) }\end{array}$ & $\begin{array}{l}\text { TEMPERATURA } \\
\text { TRAB. (graus C) }\end{array}$ \\
\hline \multirow[t]{7}{*}{ Protec } & Thermofiber 1427 & fenólica & 315 & \\
\hline & Thermofiber 1300 & fenólica & 315 & \\
\hline & Thermofiber 2020 & fenólica & 315 & \\
\hline & Thermofiber 2016 & fenólica & 315 & \\
\hline & Thermofiber 2000 & fenólica & 315 & \\
\hline & Thermofiber 1600 & fenólica reticulada & 350 & \\
\hline & Thermofiber 1350 & fenólica reticulada & 370 & \\
\hline \multirow[t]{4}{*}{ Trimat } & $\mathrm{mn} 1050$ & fenólica reticulada & 400 & 300 \\
\hline & $\mathrm{mn} 1070$ & fenólica reticulada & 500 & 350 \\
\hline & $\mathrm{mn} 1080$ & fenólica reticulada & 600 & 350 \\
\hline & & com borracha & & \\
\hline \multirow[t]{8}{*}{ Carlslile } & NF 119 & fenólica & 200 & 150 \\
\hline & NF 336 & fenólica & 315 & 200 \\
\hline & NF 350 & fenólica reticulada & 315 & 260 \\
\hline & NF 507 & fenólica reticulada & 340 & 260 \\
\hline & NF 610 & fenólica & 315 & 200 \\
\hline & NF 612 & fenólica & 315 & 200 \\
\hline & NF 780 & fenólica reticulada & 340 & 260 \\
\hline & NF 782 & fenólica reticulada & 340 & 260 \\
\hline \multirow[t]{2}{*}{ Hindustan } & HCAF 212 & fenólica & 315 & 150 \\
\hline & HCAF 216 & fenólica & & \\
\hline Champion & AFT 100 & fenólica reticulada & 340 & 280 \\
\hline \multirow[t]{2}{*}{ Brunacci } & BR1020 & fenólica & & 200 \\
\hline & BR 2020 & fenólica & & 200 \\
\hline
\end{tabular}

\subsection{4 - FIBRAS}

A utilização de fibras em lonas se dá por dois motivos, o primeiro é a melhora das propriedades mecânicas e a segunda (principalmente quando da utilização de fibras de latão) é melhorar a troca térmica nas lonas. As fibras podem ter posicionamento aleatório (“cloud"), orientadas ou trançadas. Normalmente a disposição trançada é a mais comum.

Stachowiak (2004) cita as principais fibras e suas vantagens e desvantagens (Rodrigues (2007), Bahadur (2003), e Blau (2001) citam o mesmo.

a- $\quad$ Fibra de vidro: boa resiliência térmica, mas quebradiço. 
b- $\quad$ Fibras metálicas (aço ou latão): boa resiliência térmica, mas podem aumentar desgaste do contra corpo e sofrer corrosão.

c- $\quad$ Aramida: boa rigidez em relação ao seu peso, boa resiliência térmica, boa resistência ao desgaste, porém macia tendo que ser usada com outra fibra.

d- Cerâmicas: boa resiliência térmica, mas quebradiças.

A utilização de fibras de carbono só se justifica em casos de alta solicitação como freios de aeronaves e veículos de alto desempenho, devido ao seu alto custo Stachowiak (2004).

Fibras a base de celulose podem ser usadas, como o Technocel 1004-8 da Tecnocel CFF (2006), porém seu uso não é comum. Fibras a base de lã de rocha também podem ser usadas. Na tabela 2.2 estão alguns produtos comerciais e suas fibras.

Tabela 2.2: Materiais comerciais e suas fibras.

\begin{tabular}{|c|c|c|}
\hline FABRICANTE & PRODUTO & FIBRA \\
\hline Frictie & Rockbrake & Lã de Rocha e Fibra orgânica \\
\hline Protec & Thermofiber 1427 & Fibra de Vidro \\
\hline & Thermofiber 1300 & Latão \\
\hline & Thermofiber 2020 & Latão e Aramida \\
\hline & Thermofiber 2016 & Fibra de Vidro e Aramida \\
\hline & Thermofiber 2000 & Fibra de Vidro e Latão \\
\hline & Thermofiber 1600 & Aramida \\
\hline & Thermofiber 1350 & Fibra de Vidro \\
\hline Trimat & mn 1050 & Libra Mineral e Fibra de Vidro \\
\hline & mn 1070 & Aço e Aramida \\
\hline Carlslile & mn 1080 & Latão e Fibra de Vidro \\
\hline & NF 119 & Latão e Fibra de Vidro \\
\hline & NF 336 & Latão e Fibra de Vidro \\
\hline & NF 610 & Latão e Fibra de Vidro \\
\hline & NF 612 & Latão e Fibra de Vidro \\
\hline & NF 780 & Latão e Fibra de Vidro \\
\hline Brunacci & NF 782 & Latão \\
\hline & BR1020 & Latão \\
\hline
\end{tabular}




\section{4 - DESGASTE DAS LONAS DE EMBREAGENS E FREIOS}

\subsection{1- SISTEMA TRIBOLÓGICO}

Para se definir o sistema tribológico a descrição do funcionamento do equipamento e seus movimentos, é importante entender o funcionamento dos sistemas usuais de freio e embreagem. Acionado por ar (caso embreagem) ou por molas (caso freio) o atuador se move pressionando a lamela com os elementos de atrito contra a pista, a fig. 2.15 mostra esquematicamente o sistema. A velocidade relativa máxima se dá no início da operação e decresce até que as velocidades se igualem (zero no caso de freios e velocidade da máquina caso de embreagem).

A velocidade relativa máxima varia conforme a máquina, a tabela 2.3 apresenta alguns exemplos:

Tabela 2.3: Velocidades Típicas em Prensas (dados de projetos próprios)

\begin{tabular}{|c|c|c|c|c|}
\hline Máquina & Diam. Médio & GPM & redução & V max \\
\hline & Embreagem & & & \\
\hline & $\mathrm{mm}$ & $1 / \mathrm{min}$ & & $\mathrm{m} / \mathrm{s}$ \\
\hline Prensa tipo C & 300 & 80 & 6 & 7,54 \\
\hline Prensa Repuxo & 800 & 25 & 9 & 9,42 \\
\hline Prensa Forja 1 & 1100 & 110 & 4 & 25,34 \\
\hline Prensa Forja 2 & 2300 & 100 & 1 & 12,04 \\
\hline
\end{tabular}

A pressão de contato varia de 70 a $340 \mathrm{kPa}$.

$O$ processo se repete (embreamento e frenagem) 5 vezes por minuto em prensas para metais (corte e repuxo). Já para prensas de conformação a frio e a morno de 4 a 12 vezes por minuto, porém o caso mais severo se dá em prensas de forja a quente com até 12 ciclos por minuto, com um intervalo de $2 \mathrm{~s}$ entre a transferência da pré-forma para a forma. 


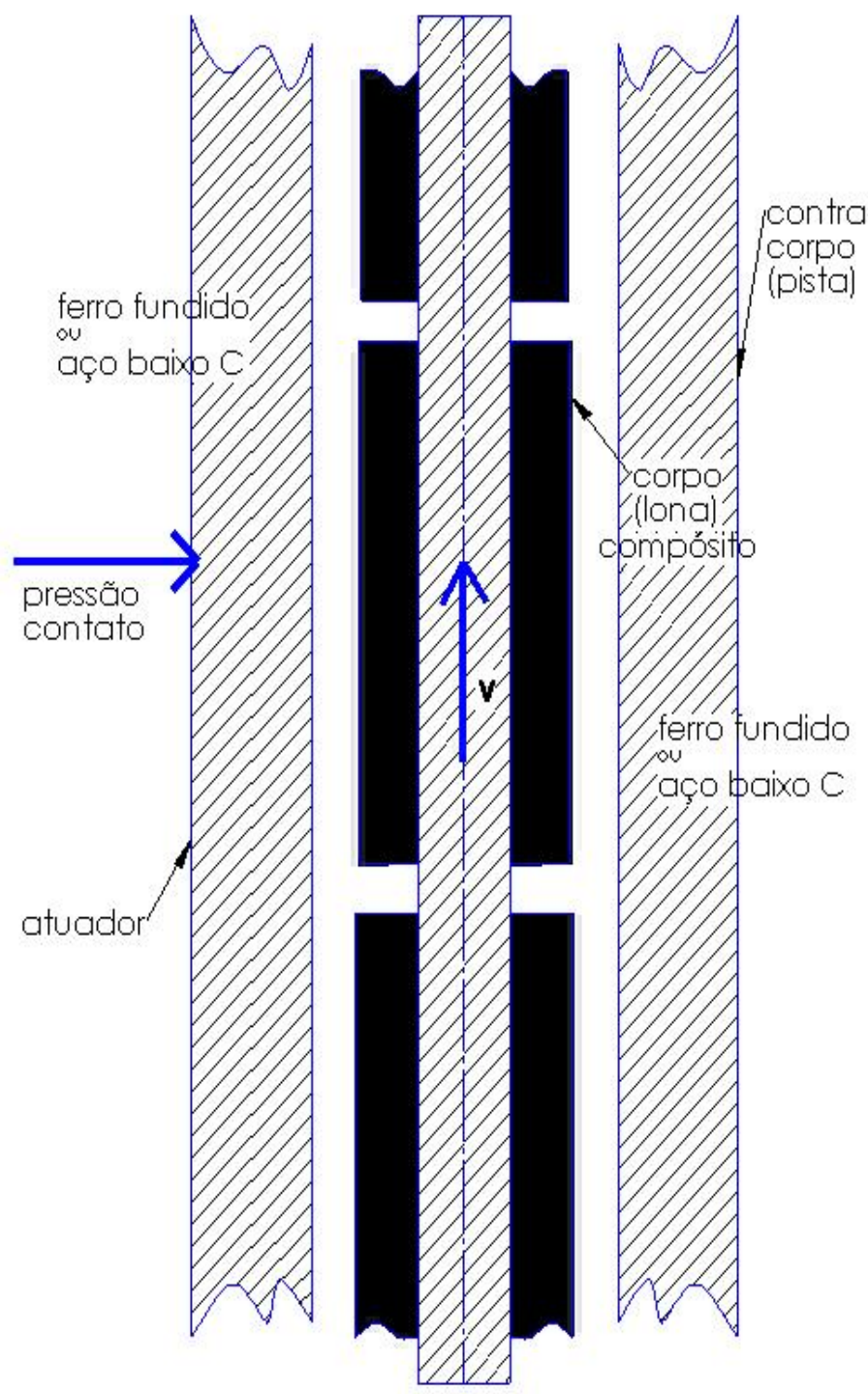

Figura 2.15: Esquema do contato

A fig. 2.16 (Bahadur (2003)) mostra um sistema tribológico, composto pelas variáveis operacionais e a estrutura do tribossistema. Pela interação das mesmas temos as interações tribológicas, que geram as perdas de energia por atrito e as perdas de massa por desgaste. Ao mesmo tempo pode-se mudar as propriedades dos materiais do sistema, retroalimentando a estrutura do mesmo.

A fig. 2.17 (Bahadur (2003)) mostra as interações tribológicas e os mecanismos de desgaste. 


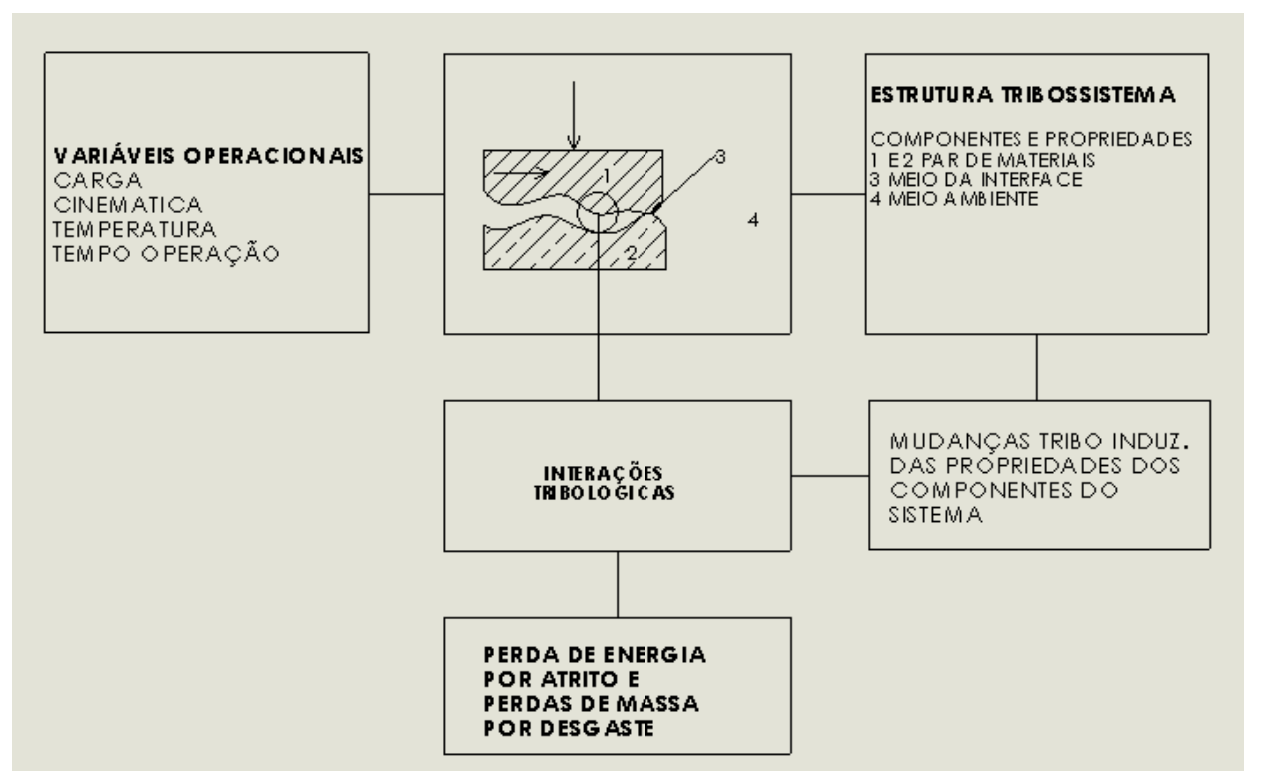

Figura 2.16: Tribossistema (Bahadur (2003)).

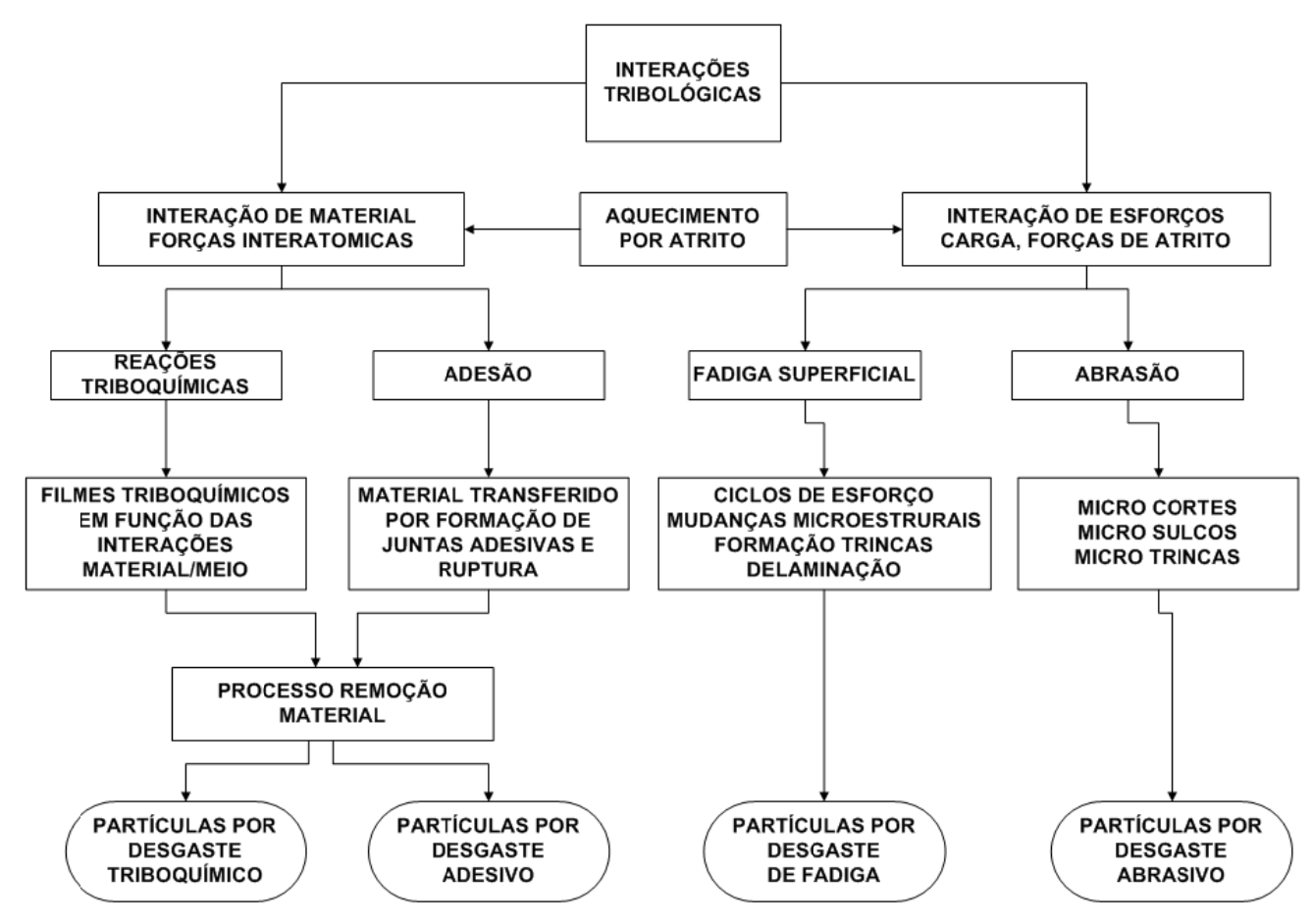

Figura 2.17: Interações Tribológicas e Mecanismos de Desgaste (Bahadur (2003)).

No contato com a carga normal e movimento relativo das superfícies entre um material polímerico e uma superfície rígida com asperezas tem-se normalmente 
força de atrito devido à contribuição da deformação ou histerese e outra devido a adesão, conforme se pode ver na fig. 2.18.

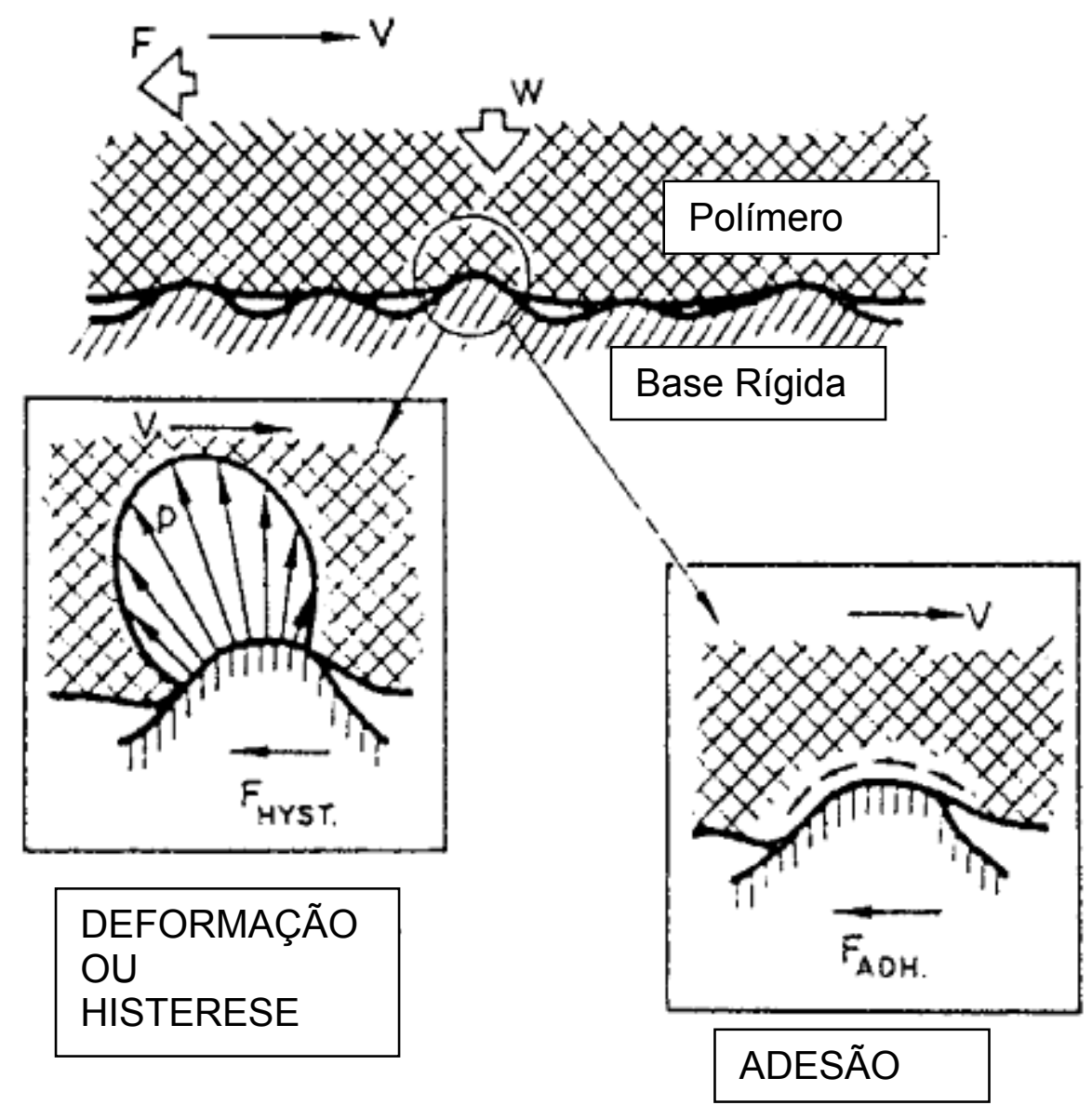

Figura 2.18: Contato entre um polímero com outro rígido com asperezas Bahadur (2003).

Segundo Bahadur: Força de Atrito - temos a contribuição da adesão e da deformação, podemos dizer que:

$$
\mathrm{F}=\mathrm{Fadh}+\mathrm{Fdef}
$$

Onde:

Fadh - força devido a adesão (forças de van der Waals, interações de dipolo, ligações de hidrogênio e cargas elétricas)

Fdef - força devido a deformação (deformação das asperezas dos polímeros, perda de energia por histerese e sulcamento).

Notar que:

A histerese depende da pressão de contato, da deformação e temperatura. 
Efeitos visco-elásticos tornam coeficientes de atrito e temperatura dependentes a eles.

A força de atrito adesiva pode ser expressa como:

$$
\text { Fadh }=\text { A } \times \text { T }
$$

Onde:

A - área real de contato

$\mathrm{T}$ - tensão de cisalhamento das uniões adesivas

A espessura do filme polimérico afetado pelo cisalhamento tem aproximadamente um micrometro de espessura.

\subsection{2 - COEFICIENTE DE ATRITO, TAXA DE DESGASTE E SUAS INFLUÊNCIAS EM FREIOS E EMBREAGENS}

O coeficiente de atrito é um coeficiente adimensional que expressa a oposição das superfícies de dois corpos em contato ao deslizar um em relação ao outro. O valor do coeficiente de atrito é característico de cada par de materiais, e não uma propriedade intrínseca do material. Depende de muitos fatores tais como o acabamento das superfícies em contato, a velocidade relativa entre as superfícies, a temperatura, etc.

O coeficiente de atrito é de importância fundamental. A partir dele se define dimensões da área de contato em função do torque requerido e pressão de contato utilizada, em freios e embreagens.

Taxa de desgaste pode ser definida como a perda de massa dividida pela distância percorrida para parâmetros conhecidos de pressão de contato, velocidade e área de contato.

Ostermayer (2003) apresenta um gráfico relacionando coeficiente de atrito, temperatura (onde $\eta$ é a temperatura média transformada, equação (9) do artigo) e um adimensional nv relativo à pressão e velocidade, figura 2.19.

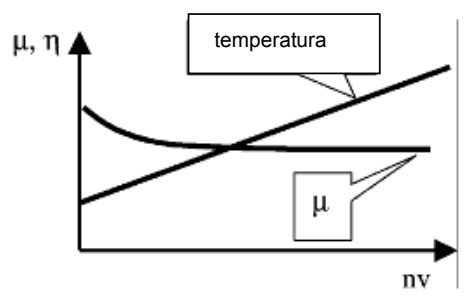

Figura 2.19: $\mu$ e $\eta \times$ nv, Ostermayer (2003). 
Wright (2007) apresenta uma curva relacionando temperatura com coeficiente de atrito e desgaste figura 2.20.

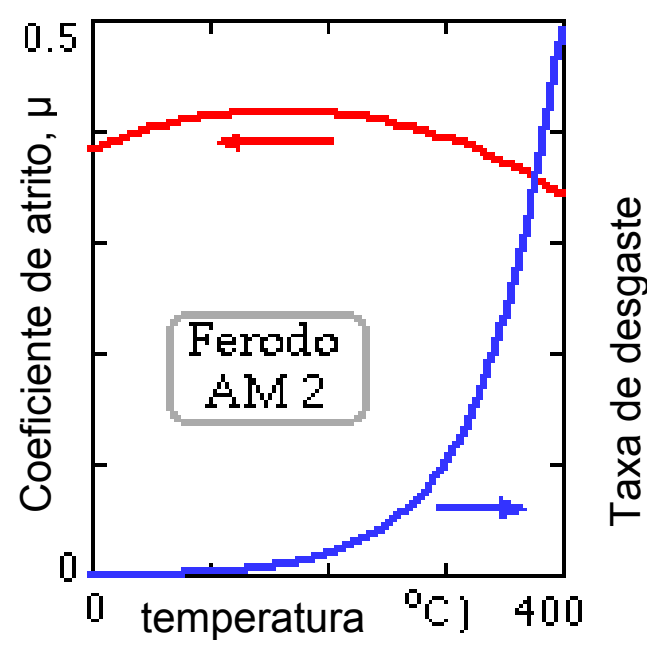

Figura 2.20: Coeficiente de Atrito e Taxa de Desgaste x Temperatura, Wright (2007).

Em projetos de freios e embreagens, parte-se de uma pressão de contato, com a área tem-se a força normal, com coeficiente de atrito temos a força e torque de atrito. Os dados dos fabricantes são restritos, alguns apenas indicam o coeficiente de atrito. Outros seguem os procedimentos da norma SAE J661 e dão valores de coeficiente de atrito a frio e a quente. Outros fornecem a curva em função da temperatura. Curvas de atenuamento ("fade") e recuperação ("recovery") em função da temperatura são fornecidas. Adotam-se sempre procedimentos conservativos na utilização de coeficientes de atrito, muitas vezes super dimensionando o equipamento.

A taxa de desgaste vai definir a espessura das lonas para um determinado intervalo de manutenção. Convém lembrar que o ponto de projeto deverá ser o de máximo desgaste. Assim por exemplo: freios industriais são acionados por mola e soltos por trabalho externo e o mínimo pré-tensionamento da mola se dá com as lonas desgastadas.

Blau (20001) e Bahadur (2003) apresentam a formulação de desgaste abaixo:

$$
A W=\alpha P^{a} V^{b} t^{c}
$$

Onde: $\quad A W-$ Volume perdido por desgaste 


$$
\begin{aligned}
& a, a, b \text { e c valores experimentais para cada par tribológico } \\
& P \text { - pressão normal } \\
& V \text { - velocidade de relativa de deslizamento. } \\
& t \text { - tempo de escorregamento }
\end{aligned}
$$

Marusic (2004) mostra uma série de resultados de ensaios pino sobre disco relacionando a taxa de desgaste com o número total de revoluções.

Os fabricantes fornecem a taxa de desgaste conforme norma SAE J661, que é um valor único. Outra característica importante que muito poucos fabricantes fornecem é a máxima velocidade de atrito ou de contato (rubbing speed).

Rodrigues (2007) também comenta a variação do coeficiente de atrito com a velocidade, mas relativo à matriz polimérica. Neste caso para alguns polímeros ocorre aumento do coeficiente de atrito e para outros a diminuição. Rodrigues (2007) comenta ainda o problema da influencia da temperatura nos resultados.

Finalmente as propriedades mecânicas da lona são importantes como máximas tensões admissíveis de compressão, flexão, cisalhamento e dureza Gogan (medida de dureza conforme norma SAE J379a).

Um valor empírico que chamam de capacidade de dissipação (ou termo análogo) dado em $\mathrm{kcal} / \mathrm{cm}^{2}$, que expressa a área de contato necessária para dissipar uma dada quantidade de calor gerado é encontrado na literatura técnica: Carvill (2003), Collins (2006), Faires (1975), Mott (1992), Nieman (1971), Norton (1998), Shigley (1984), Spotts (1998) e em literatura específica: Goizper (2006), Warner (2006), Wichita (2001), Ortlinghaus (2006), Airflex (1997). A utilização desses valores está restrita a condições de trabalho (temperatura, pressão de contato e velocidades dentro de certas faixas) e com a geometria das superfícies de troca térmica e sua velocidade. Então ao se utilizar tais valores devem-se usar os apropriados para a configuração em projeto.

Wright (2007) é quem melhor expõe os dados da capacidade de dissipação relacionados ao tipo de trabalho, para o caso em estudo: Trabalho pesado e freqüente onde vida é crítico, freqüência de aplicação muito alta para permitir considerável refrigeração entre aplicações, prensas, escavadeiras, martelos de queda. Temos conforme o tipo de freio ou embreagem a máxima capacidade de calor fornecido e a faixa da pressão de contato. 

a- $\quad$ Disco de freios uso ocasional $1200 \mathrm{~kW} / \mathrm{m}^{2}$
$350 / 1750 \mathrm{kPa}$
b- Freios a tambor
$300 \mathrm{~kW} / \mathrm{m}^{2}$
$70 / 350 \mathrm{kPa}$
c- Embreagens Cônicas
$240 \mathrm{~kW} / \mathrm{m}^{2}$
$70 / 350 \mathrm{kPa}$
d- Freios e Embreagens de Disco $120 \mathrm{~kW} / \mathrm{m}^{2}$
$70 / 350 \mathrm{kPa}$

Em negrito o caso estudado, freios e embreagens de prensas.

\section{Variação do desgaste}

Ensaios realizados por Pogosian e Lambarian (1997) são mostrados na figura 2.21 .

Os materiais $A, B, C, D$ e $E$ são materiais de atrito com reforço de fibras de asbestos e com composição em peso variando de: resina de 15 a 27,71\%, cargas de 69,55 a 81,77\%, aceleradores de 0,18 a 1,75\% e borrachas de 0,66 a $6,40 \%$. Superfície de contato em aço. As velocidades variaram de 0,44 a 2,2 $\mathrm{m} / \mathrm{s}$. A carga normal de $61,2 \mathrm{~kg}$. Os resultados mostram o aumento do desgaste com aumento da carga, velocidade ou tempo.

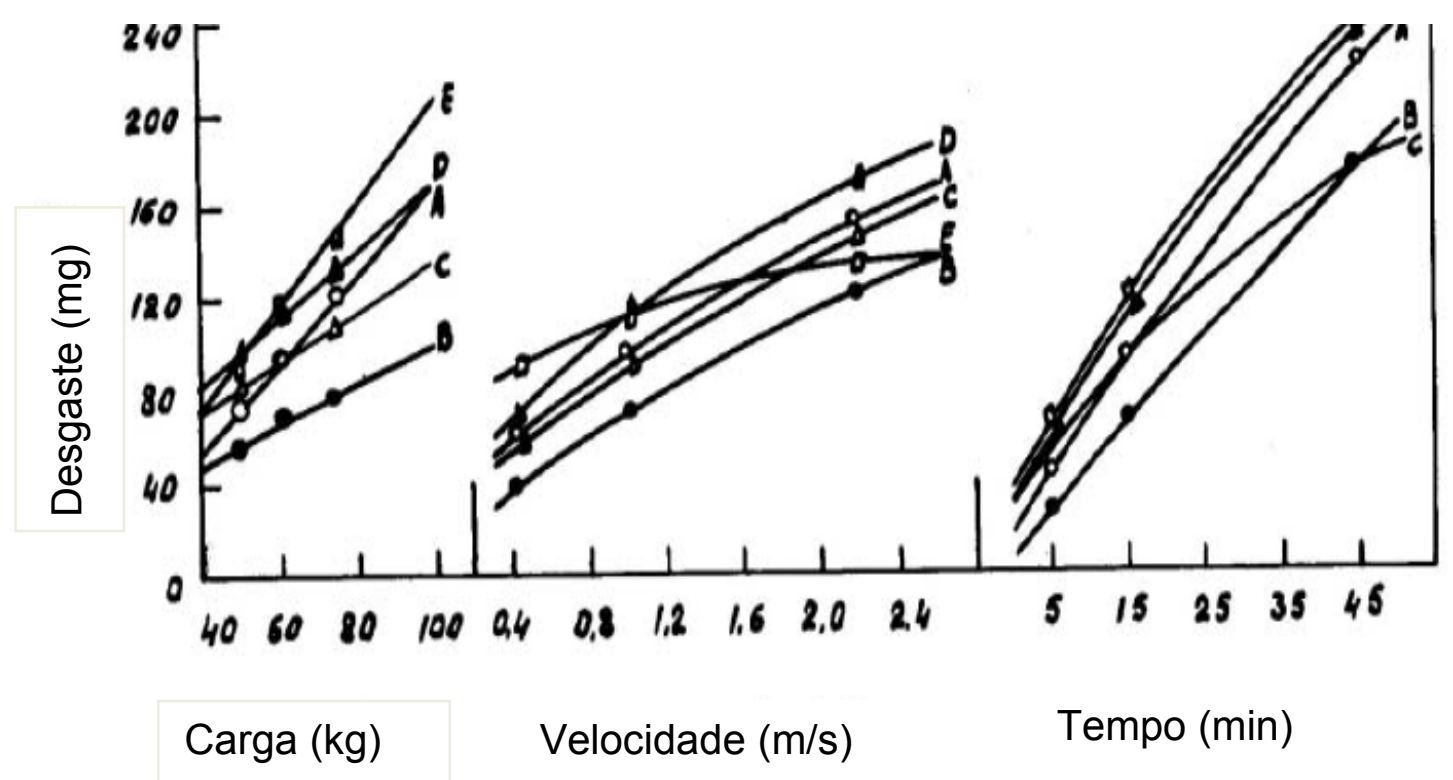

Figura 2.21: Desgaste de materiais de atrito com reforço de asbestos, Pogosian e Lambarian (1997).

Halberstadt, Mansfieldand e Rhee (1977) realizaram ensaios de desgaste em função da temperatura para um material padrão (15\% de resina fenólica, 37,5\% fibra de asbestos, $36,5 \%$ pó de casca de castanha de caju, $11 \%$ de modificador inorgânico) e um material experimental (titianato de potássio + 
fibras de asbestos) contra tambores de ferro fundido. A velocidade de escorregamento era de $7,6 \mathrm{~m} / \mathrm{s}$ e a força ajustada para um torque constante de $40 \mathrm{~N}$ x m. Resultados estão apresentados na fig. 2.22. Na fig. 2.23 apresentase o coeficiente de atrito em função da temperatura para o material padrão e o experimental. Note que o titianato de potássio promove maior coeficiente de atrito a altas temperaturas.

Os autores comentam os mecanismos de desgaste: nas regiões de baixa temperatura há desgaste adesivo e abrasivo, nas regiões de alta temperatura temos um processo termicamente ativado em razão da degradação térmica da resina fenólica que é pirolizada, oxidada e finalmente desgastada em forma de gases e outros produtos de degradação. Oxidação não é um mecanismo de controle, pois a energia de ativação é muito inferior que a de oxidação (30 kcal/ $\mathrm{mol})$.

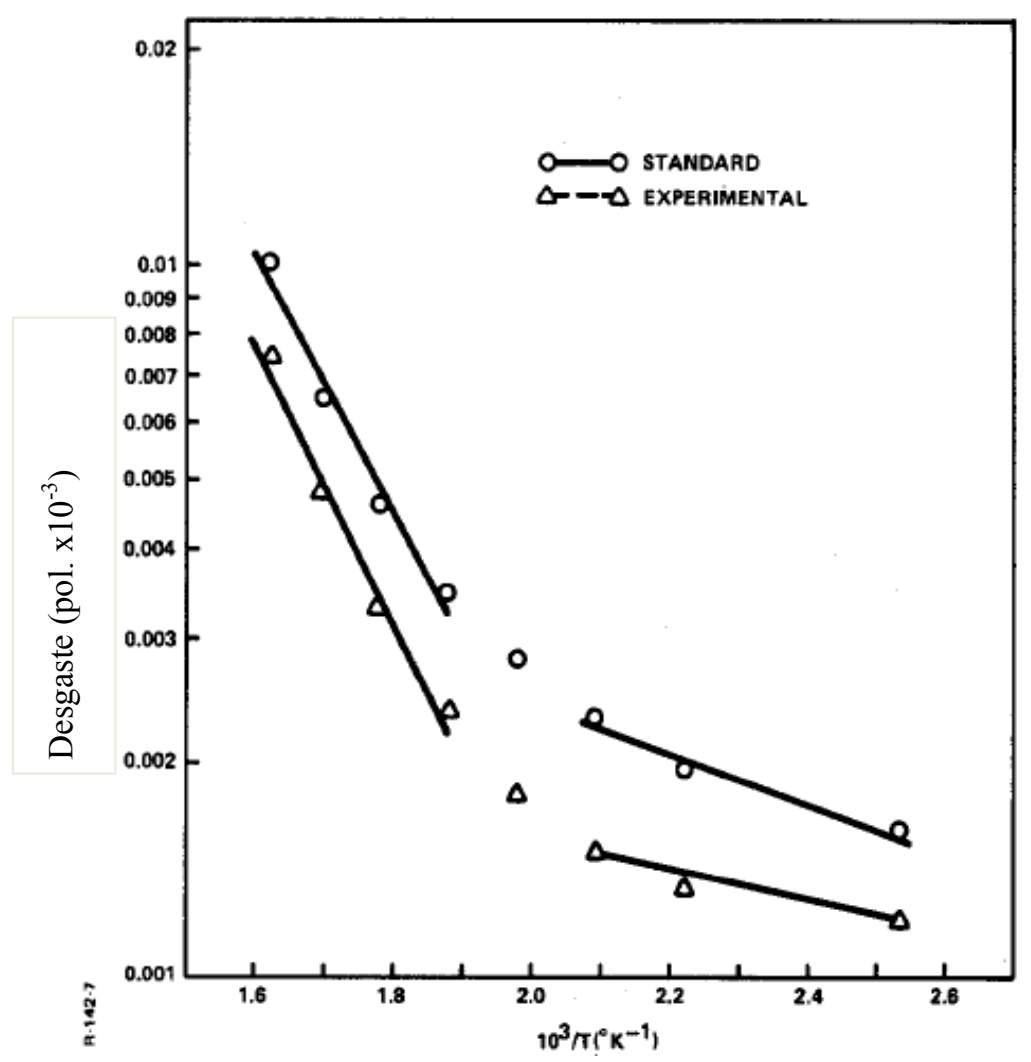

Figura 2.22: Ensaios de desgaste em função da temperatura, Halberstadt, Mansfieldand e Rhee (1977). 


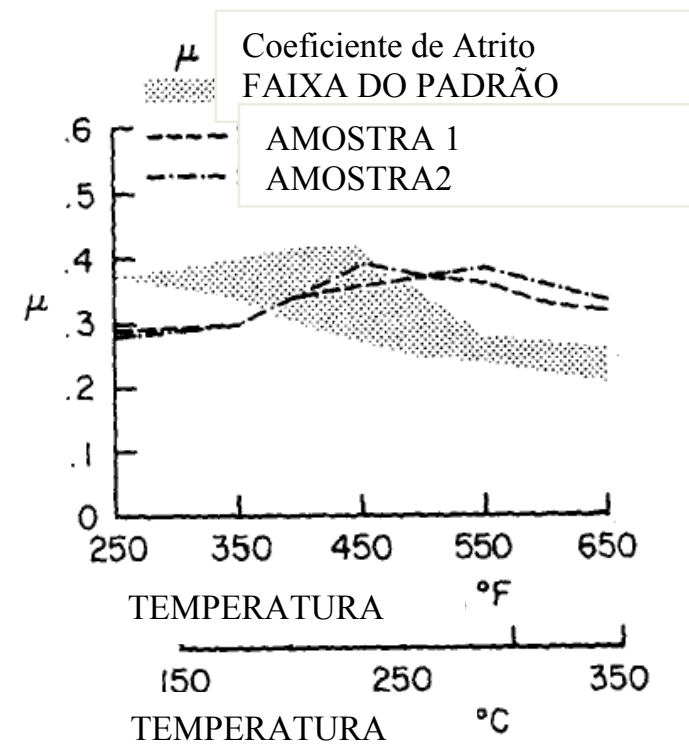

Figura 2.23: Coeficiente de atrito $\mathrm{x}$ temperatura, Halberstadt, Mansfieldand e Rhee (1977).

Gopal (1995) ensaia materiais de atrito reforçados com fibras curtas de vidro e carbono para verificação do fenômeno de atenuamento ("fade") e recuperação ("recovery"). Os materiais analisados tinham a seguinte composição:

Compósitos reforçados com fibra de carbono (CFRFM) em volume: $34,5 \%$ de fibra carbono, 2,3\% de fibra de aço, resina fenólica modificada com caju, partículas fenólicas $21,67 \%$ e $\mathrm{BaSO}_{4} 7,6 \%$

Compósitos reforçados com fibra de vidro (CGRFM) material reforçado com fibra de vidro.

Observou-se dano térmico e "pitting" em altas temperaturas: e em baixas temperaturas e velocidades observou-se afinamento das fibras e seu arrancamento. Os compósitos com fibra de vidro apresentaram menor crescimento da taza de desgaste em função da temperatura. A carga aplicada foi de $669 \mathrm{~N}$ e velocidade de $5,8 \mathrm{~m} / \mathrm{s}$. Resultados na fig. 2.24 .

O comportamento do atrito e desgaste de materiais de freio é bastante complexos em razão da variação de velocidades e cargas, dissipação de energia e aumento de temperatura.

O fenômeno de atenuamento ("fade") e recuperação ("recovery")fazem o atrito variável. 

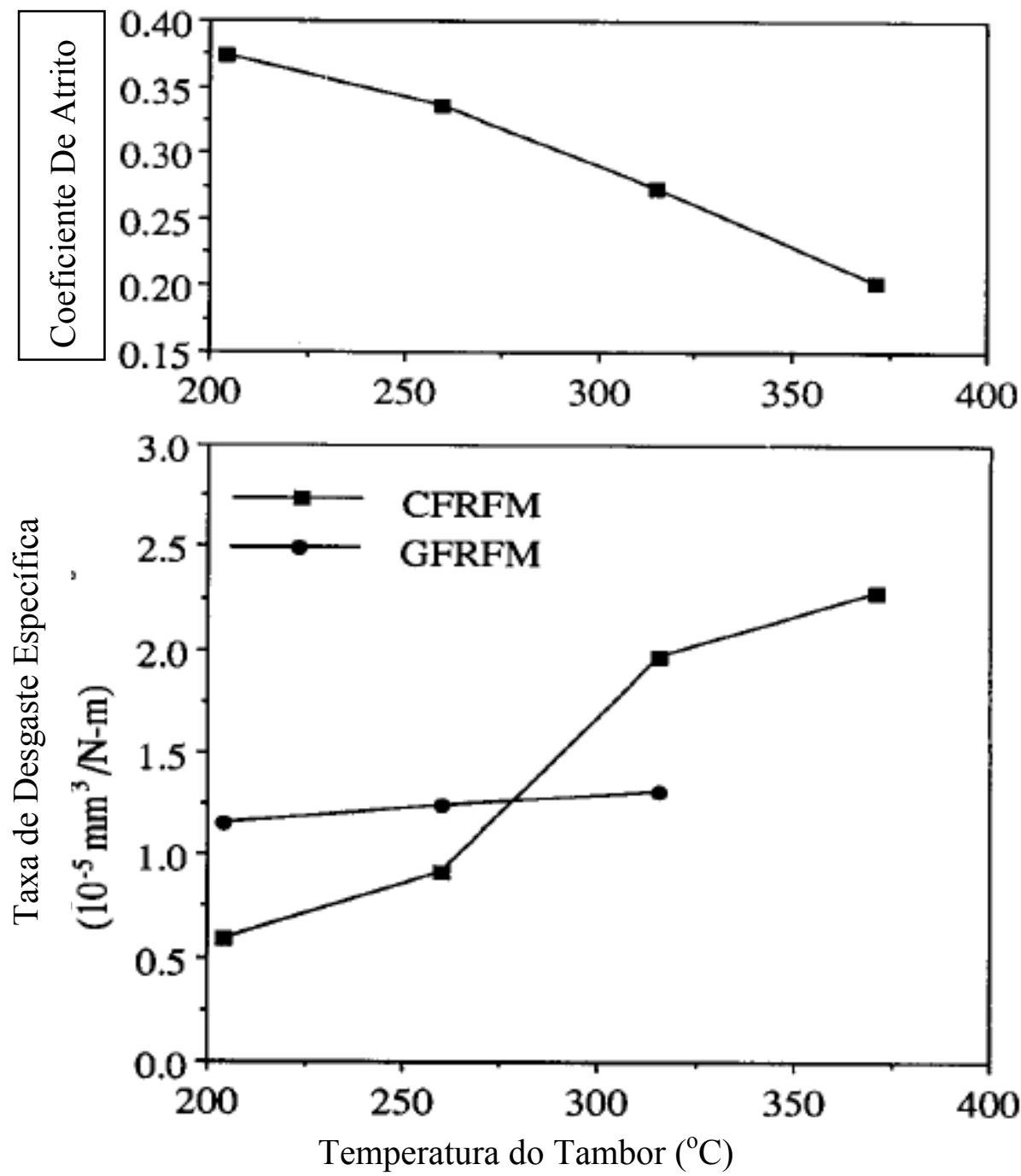

Figura 2.24: Efeito da temperatura na faixa de desgaste, Gopal (1995).

Bahadur (2003) afirma que com tantos constituintes nos materiais de atrito que não se pode prever seu comportamento.

O coeficiente de atrito decresce com o aumento de temperatura: fenômeno de atenuamento ("fade")

Desgaste cresce com o aumento de temperatura para as faixas de operação de freios e embreagens de prensas. 


\section{3- OBJETIVOS DA INVESTIGAÇÃO}

$\mathrm{Na}$ introdução foi mostrado um caso de desgaste de uma embreagem em curto espaço de tempo de uma prensa. Existem outros equipamentos que também apresentam desgaste acentuado da embreagem, por exemplo, os bate-estacas utilizados na construção civil. Uma análise maior da razão da falha (desgaste acentuado) deve ser feita. No caso mostrado foi notado que os resíduos variavam de um avermelhado, áspero ao contato com as mãos a um preto bem mais liso e ficando as mãos sujas de grafite. Isso indicava a possibilidade de haver mais de um fator causando a perda de massa.

Da revisão bibliográfica ressaltam-se alguns pontos relevantes:

1- Ao embrearmos há grande geração de calor. Existe um balanço entre o calor dissipado por convecção e o gerado. Quanto menor for o tempo entre inserções da embreagem maior é o calor inserido no sistema e maior é a temperatura da embreagem.

2- Os compósitos têm uma característica, suas propriedades mecânicas seguem a lei das misturas, e Stachoviak (2000) afirma que o coeficiente de atrito também segue a lei das misturas. Então imaginando que a superfície em contato sejam "duas", uma de polímero outra de abrasivos e o trabalho por atrito (que seria transformado principalmente em calor, no caso analisado) é em cada "superfície" proporcional ao coeficiente de atrito de cada material. O abrasivo tem coeficiente de atrito superior ao do polímero, então o fluxo de calor pelo abrasivo é superior ao fluxo pelo polímero.

3- Os estudos realizados mostram que, o coeficiente de atrito decresce com o aumento da temperatura e a taxa de desgaste cresce com a temperatura.

4- Bahadur (2003) e Halberstadt (1977) comentam que nas regiões de alta temperatura existe um processo termicamente ativado em razão da degradação térmica da resina fenólica que é pirolizada, oxidada e finalmente desgastada em forma de gases e outros produtos de degradação.

O exposto acima leva a criação da seguinte hipótese:

As figuras 1.1 e 1.2 mostram duas colorações dos resíduos ("debris") indicando a possibilidade da ocorrência de desgaste em dois regimes (moderado e severo) e isto esteja relacionado com o regime de trabalho da máquina e o 
aquecimento das superfícies de atrito. Máquinas com tempo entre inserções menores apresentam mais resíduos escuros e as com maior tempo apresentam mais "debris" avermelhados.

As temperaturas de riscamento ("flash temperatures") são as temperaturas do contato abrasivo contra corpo, são altas aquecendo o abrasivo, que por sua vez aquece ao polímero, o mesmo se degrada ao redor do abrasivo e se destaca. Em algumas embreagens nota-se na troca das "lonas" uma superfície áspera cheia de pequenos furos. Supõe-se que a cor avermelhada se dá pelo fato do abrasivo mais comum ser a base de ferro, oxidando-se no processo e o óxido de ferro dá a cor avermelhada aos resíduos, fig. 3.1

\section{PERFIL DE IEMPERATURAS - APROXIMADO}

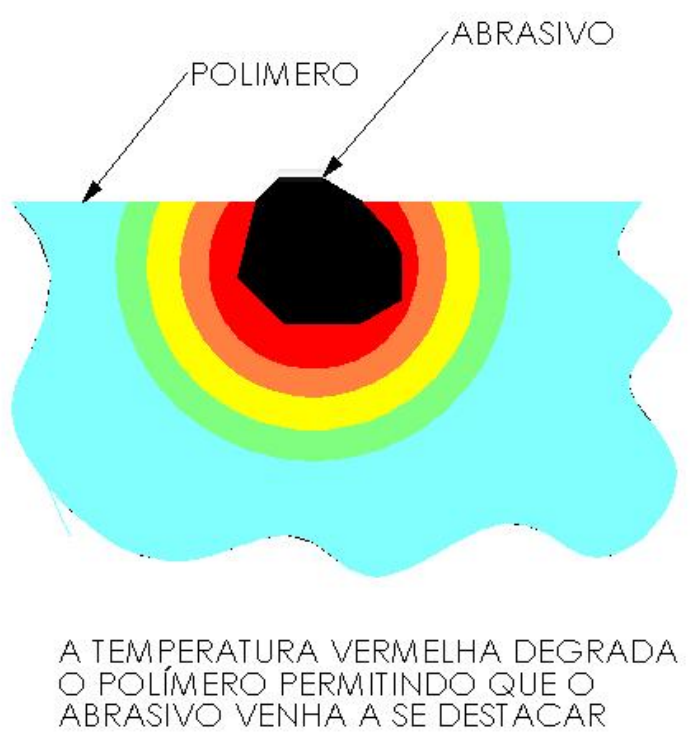

Figura 3.1: Resíduos avermelhados

Com o aumento da severidade do uso aumenta a temperatura do compósito, existe um crescimento da área com temperatura acima da temperatura limite para uso da resina e maior parte da perda de massa é devida a degradação da base polimérica, fig. 3.2 . 


\section{PERFIL DE TEMPERATURAS - APROXIMADO}

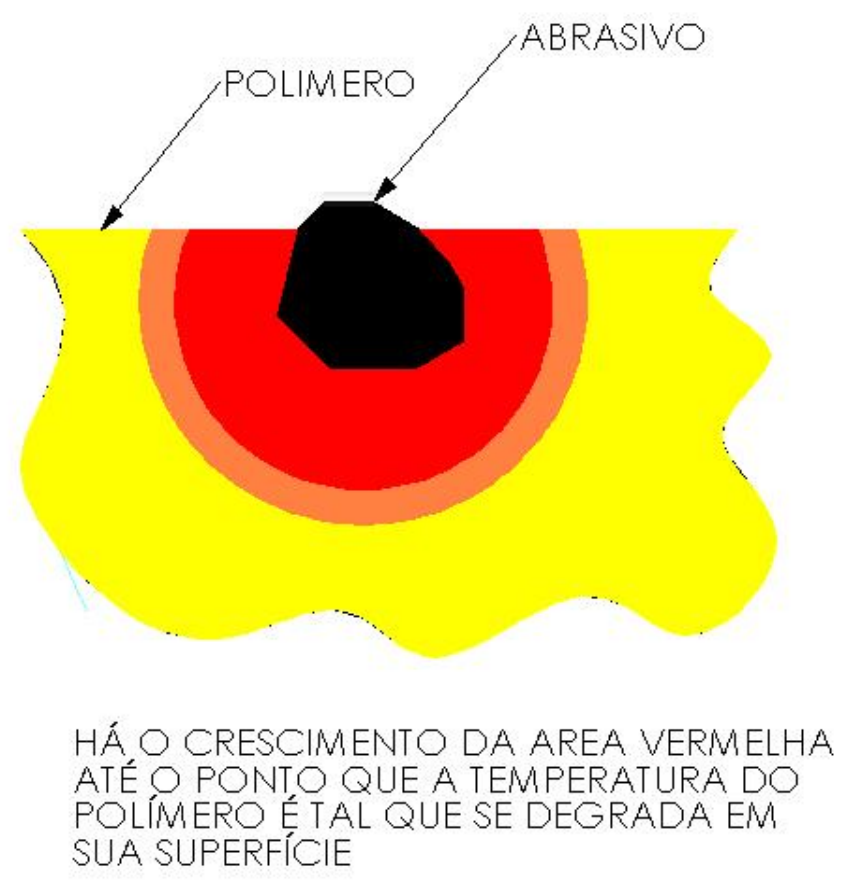

Figura 3.2: Resíduos pretos

A hipótese está baseada no aquecimento do abrasivo no contato e a degradação do polímero que é seu engastamento. Perdendo-se material com isso. Claro que o polímero ao atritar-se na pista se aquece e degrada um filme do mesmo. O aquecimento do abrasivo é então função do que se vê no diagrama de Ashby modificado fig. 3.3, da temperatura de riscamento. Condições de desgaste moderado (trocas anuais de lonas) encontram-se resíduos avermelhados e poucos resíduos pretos. Quando se aumenta a severidade do desgaste, a ocorrência de resíduos pretos cresce até o ponto de só se encontrar resíduos preto. Resíduos avermelhados caracterizam um desgaste moderado. Resíduos pretos caracterizam um desgaste severo.

A área azul clara de baixo desgaste não ocorre em freios e embreagens. As áreas coloridas de verde a vermelho são onde existe a perda de material abrasivo, conforme segue-se para a direita no gráfico esse fenômeno se acentua. Como dito anteriormente as temperaturas de riscamento influenciam diretamente na degradação do polímero no entorno do abrasivo. A área vermelha é onde se tem a degradação acentuada do polímero (debris preto). 


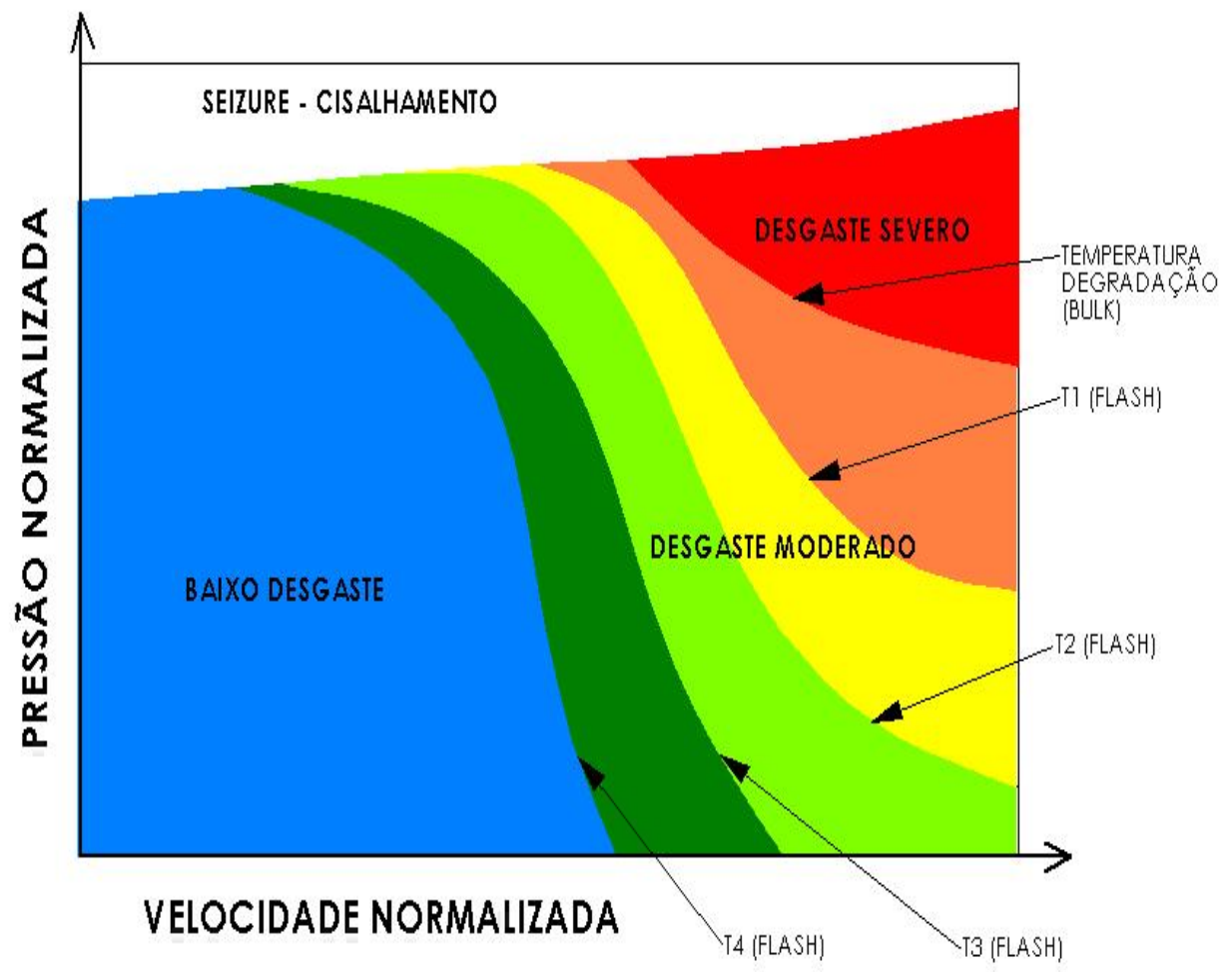

Figura 3.3: Diagrama de Ashby modificado, Ashby (1992).

O objetivo deste trabalho é verificar a validade da proposta da perda de massa por degradação do polímero. Para tal serão utilizados simulações numéricas e ensaios. Finalmente se tentará associar as diversas variáveis e sua influência no dimensionamento de embreagens.

Importante notar, que a hipótese só é válida, para abrasivos bons condutores de calor, como o usado na lona da fig. 1.1. 


\section{4- MATERIAIS E MÉTODOS}

\section{1- ESCOLHA DE UMA LONA PARA ENSAIOS}

Este trabalho não tem o objetivo de comparar diversos materiais de lonas entre si, mas estudar o comportamento de um material comum em lonas na aplicação em freios e embreagens de prensas com grande número de inserções por minuto. Utilizou-se um material disponível no mercado e utilizado por muitas prensas. Uma lona em resina fenólica com fibras de latão é o usual e existem vários fornecedores nacionais ou estrangeiros desse tipo de material. Existem opções de materiais com maior tecnologia, que são usados apenas em alguns casos em virtude de seu elevado custo. Entretanto, a não utilização dos mesmos não quer dizer que não sejam a melhor escolha ou que não seja o futuro para essa aplicação.

Esses materiais se caracterizam por uma superfície grosseira em termos de acabamento (tendo tempos de adaptação ou "running in" bastante elevados) e uma distribuição aleatória de fibras e abrasivos. Esta aleatoriedade mostra ser um problema nos ensaios, já que corpo-de-prova da mesma lona apresenta variações consideráveis de coeficiente de atrito local. Porém seu valor médio confere com os da especificação do fabricante.

A lona utilizada é mostrada nas figuras 4.1 a 4.4. Onde nota-se em amarelo as fibras de latão e algumas fibras de aço distribuídas aleatoriamente, apesar das lonas serem usinadas as lonas existem ainda vazios bastante significativos na superfície, riscos provavelmente da ferramenta de usinagem. Existem algumas manchas mais escuras (pretas) possivelmente grãos de coque (utilizado também como abrasivo).

\subsubsection{DESCITIVO DE SUA COMPOSIÇÃO}

A lona estudada é uma lona rígida moldada em resina fenólica, isenta de amianto, com fibras de latão, coeficiente de atrito típico de 0,45 e para trabalho entre $100^{\circ} \mathrm{C}$ e $200^{\circ} \mathrm{C}$ (dados do fabricante). 


\subsubsection{DETERMINAÇÃO DA PERDA DE MASSA EM FUNÇÃO DA}

TEMPERATURA

O procedimento para determinação da perda de massa em função da temperatura foi feita por um ensaio simples, uma amostra de peso conferido da Iona é colocada em forno, aquecida a uma determinada temperatura e mantida por 15 minutos à temperatura especificada. Após isso é pesada e verificada sua perda de massa. Esse ensaio tem por objetivo verificar a perda de massa e em qual temperatura há um crescimento significativo da mesma, indicando o processo de degradação da base polimérica (fenol-formol).

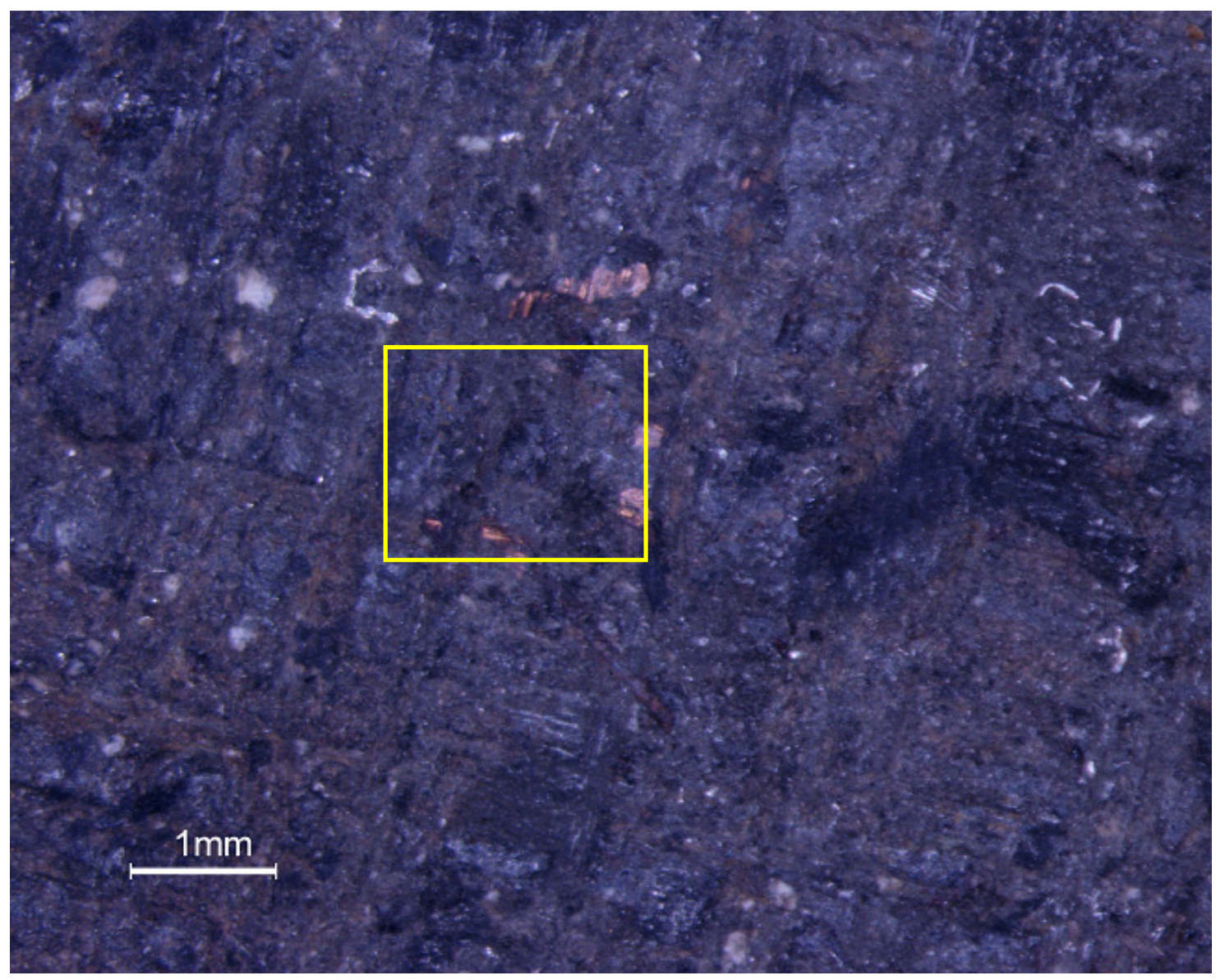

Figura 4.1: Lona utilizada, aumento $10 \mathrm{x}$. 


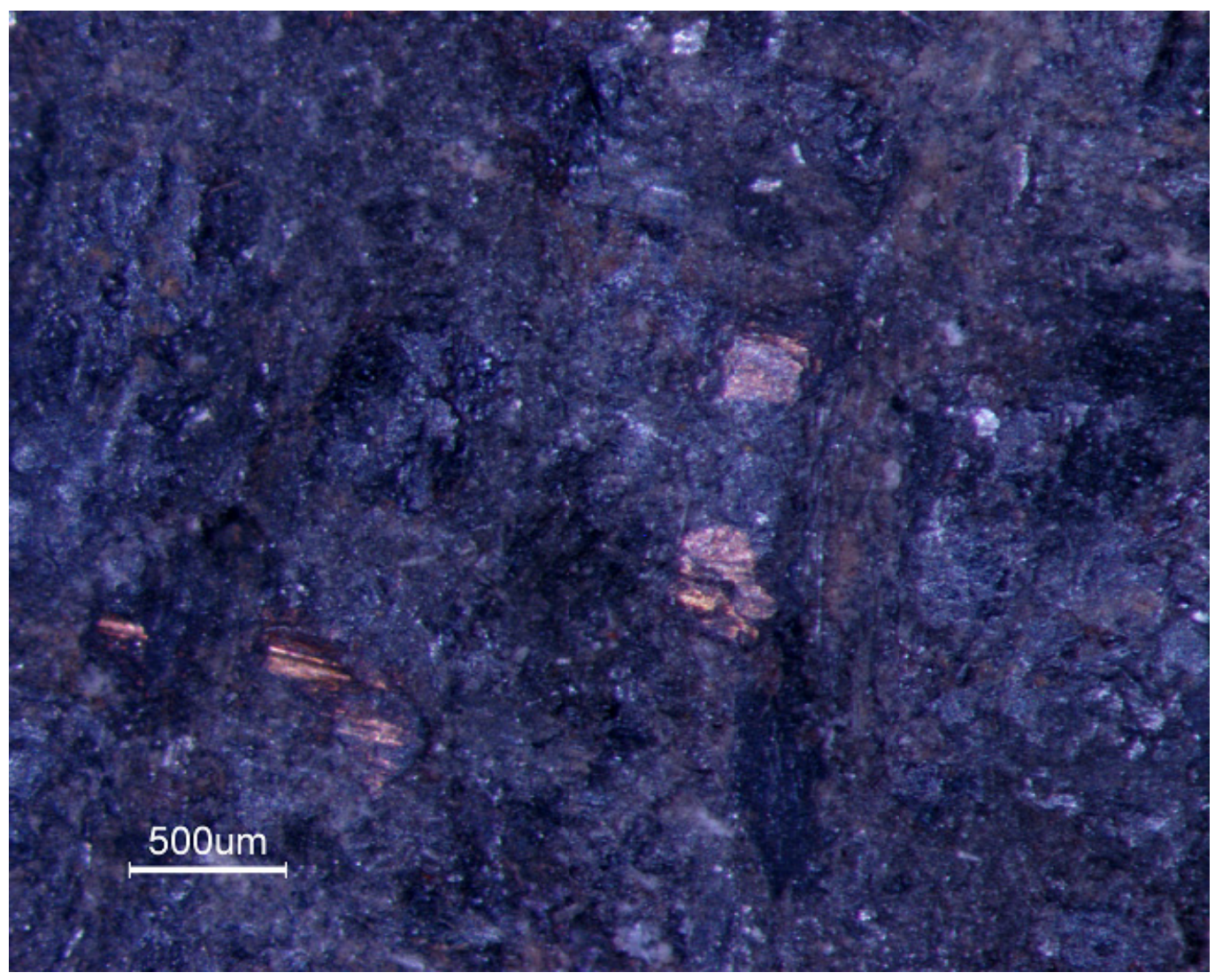

Figura 4.2: Detalhe da figura 4.1 (ampliação 20 x)

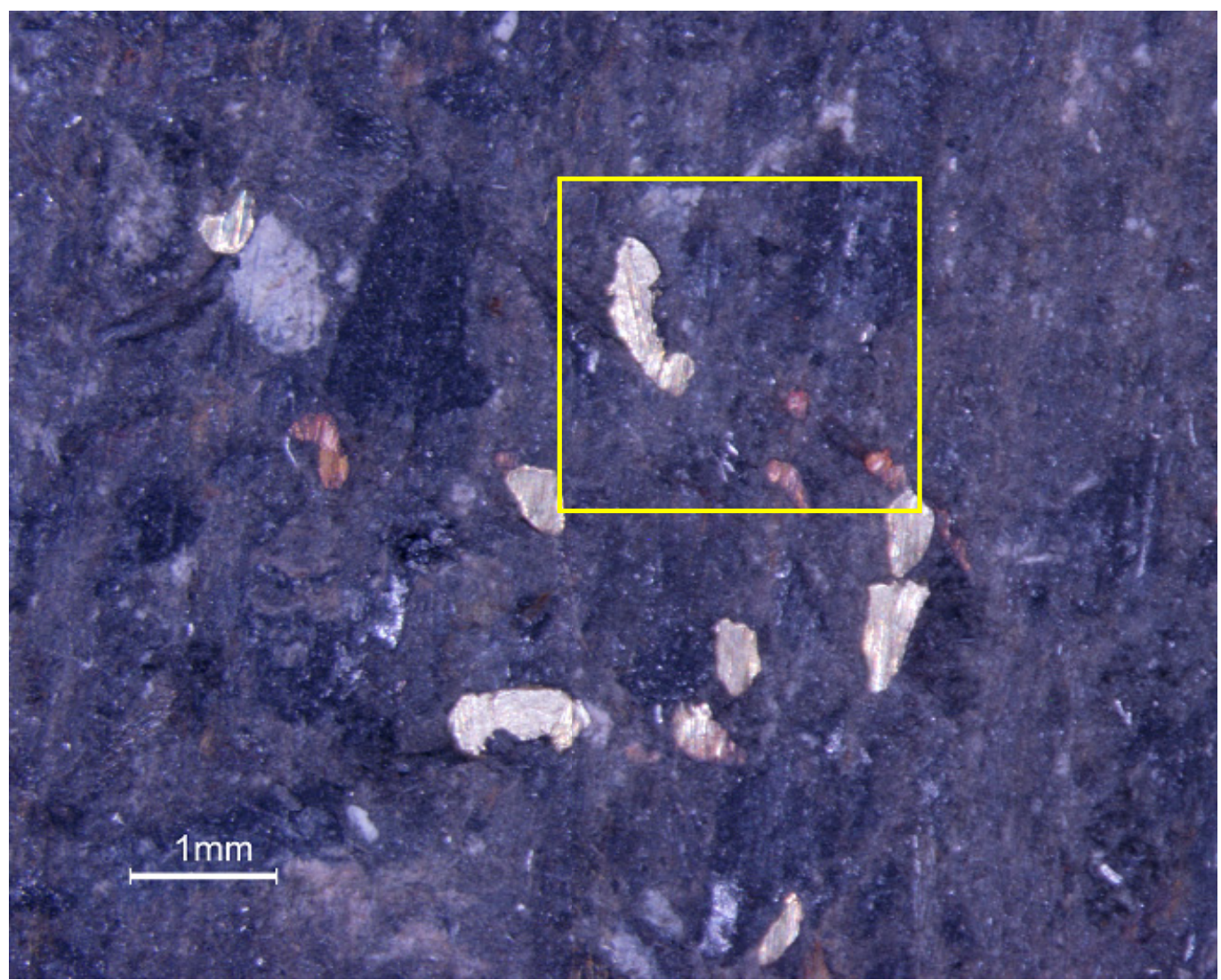

Figura 4.3: Lona utilizada, aumento $10 \mathrm{x}$. 


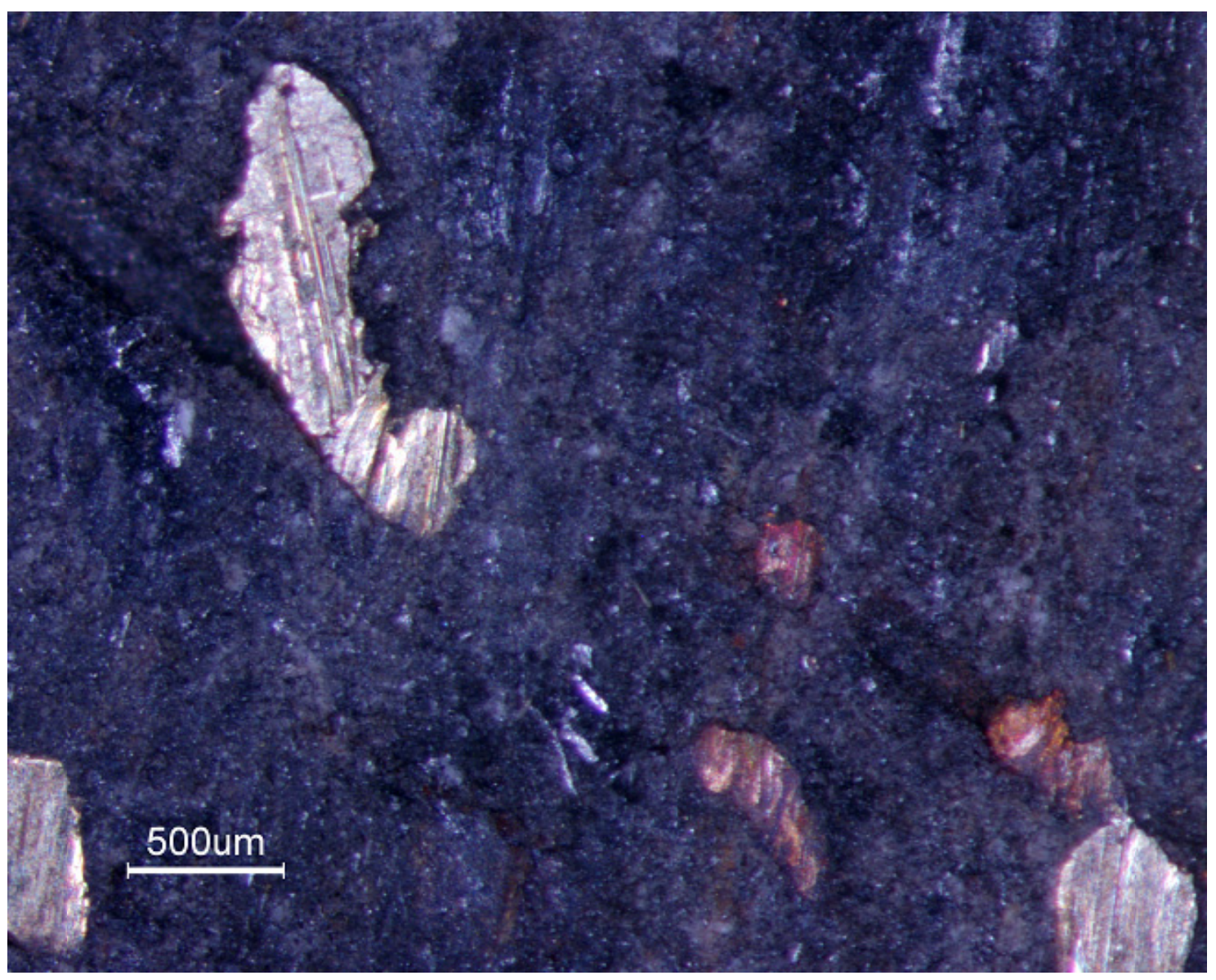

Figura 4.4: Detalhe da figura 4.3 (ampliação $20 \mathrm{x}$ )_. 


\section{2 - ENSAIOS PINO SOBRE DISCO}

Os ensaios de pino sobre disco foram realizados no Laboratório de Fenômenos de Superfície da Universidade de São Paulo, em equipamento Plint TE 67.

A Plint TE 67, \# 8556 é uma máquina de ensaio tipo pino-disco, fabricada pela Plint \& Partners Ltd., fig. 4.5 e fig. 4.6

As características principais da máquina são:

Velocidade de escorregamento:

Até $4 \mathrm{~m} / \mathrm{s}$ a 1000 RPM com $40 \mathrm{~mm}$ de raio

Até $8 \mathrm{~m} / \mathrm{s}$ a 2000 RPM com $40 \mathrm{~mm}$ de raio

Carga de Contato

De 50 a $1000 \mathrm{~N}$ (carregamento pneumático)

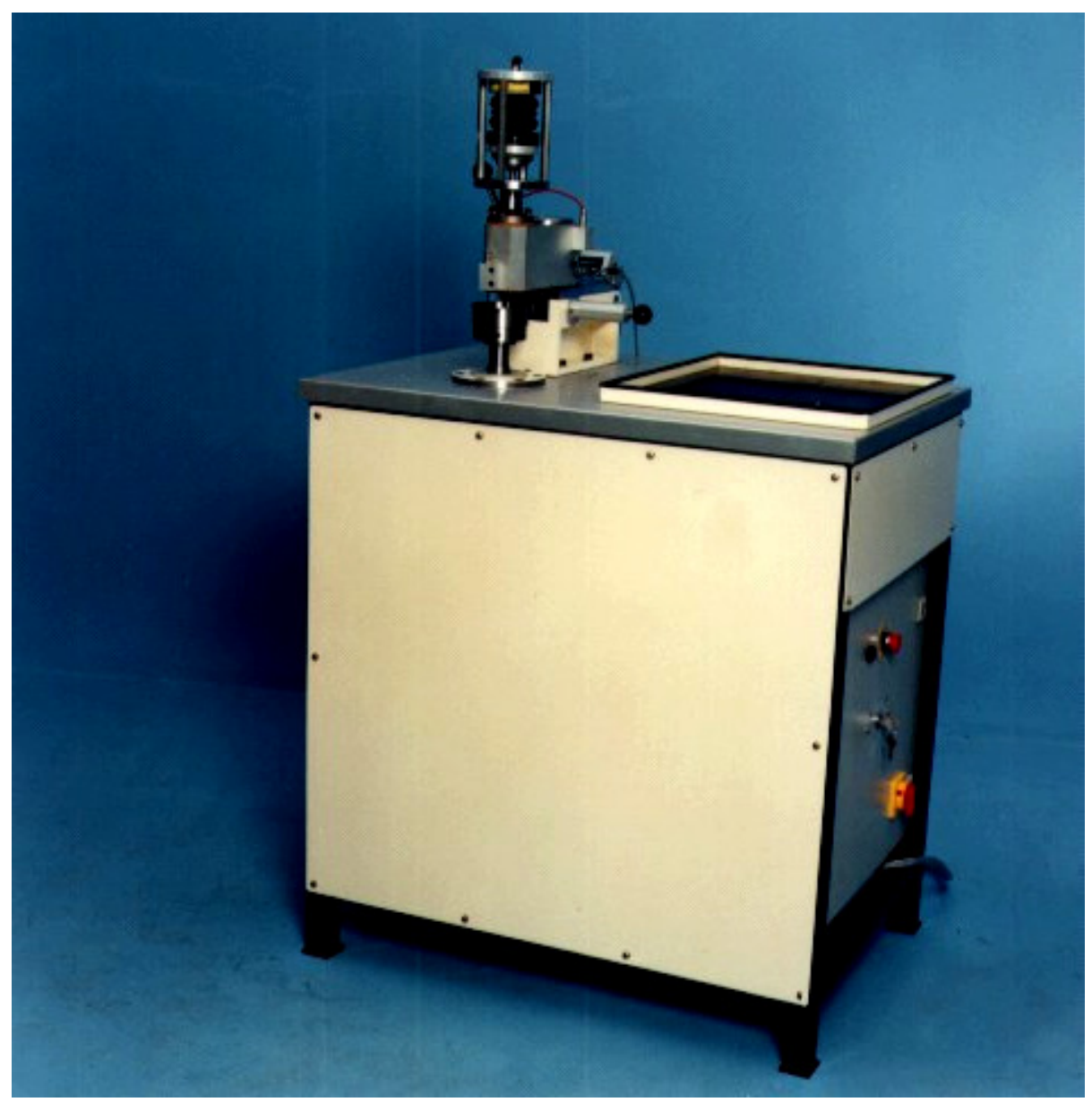

Figura 4.5: Plint TE 67 


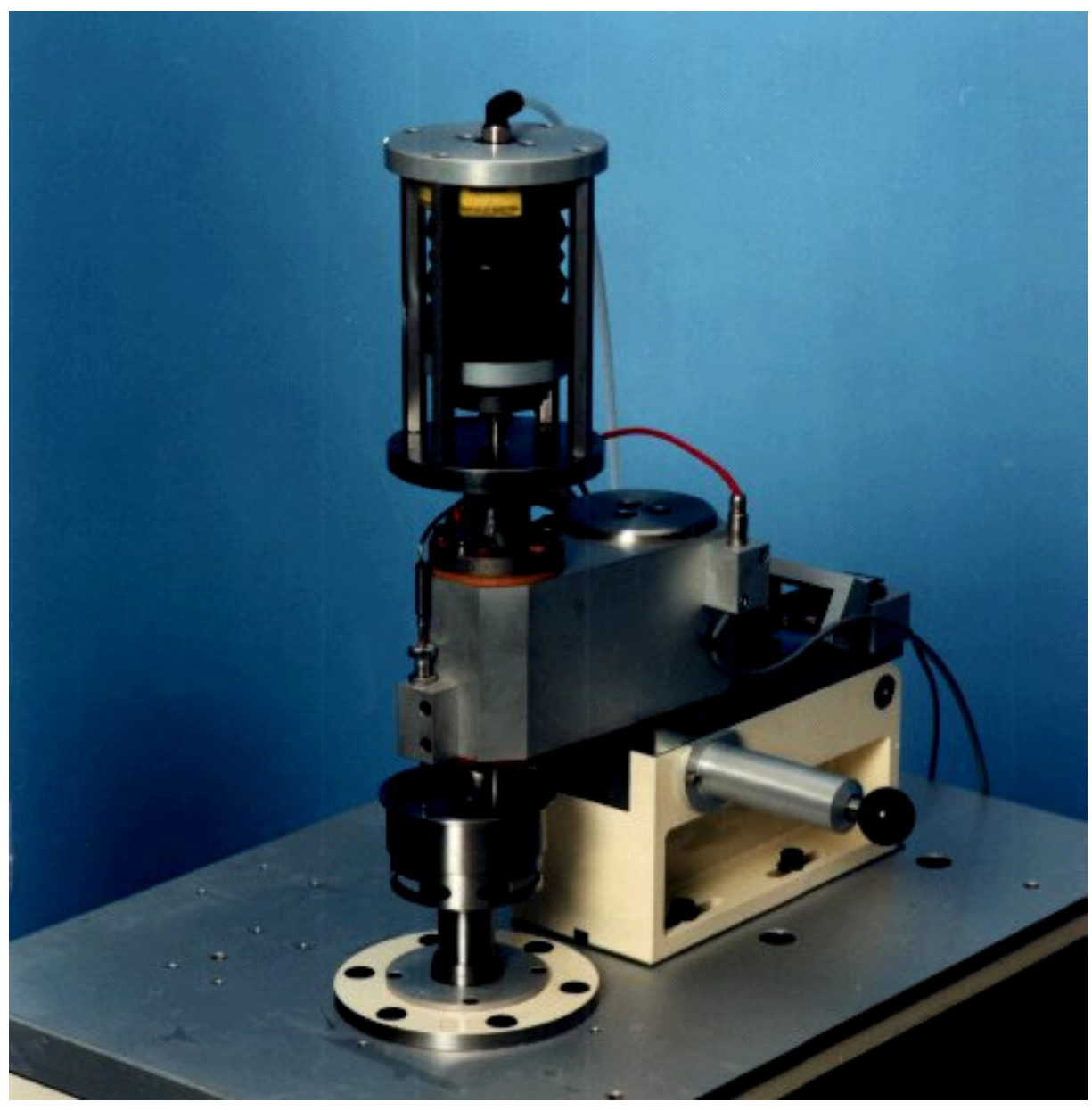

Figura 4.6: Detalhe do cabeçote da máquina

Os corpos-de-prova, material de atrito Brunacci BR2020, foram preparados pelo fornecedor a partir de lonas de $4,8 \mathrm{~mm}$ de espessura, tendo uma face usinada para atingir-se a espessura de $3 \mathrm{~mm}$. A usinagem da face foi para diminuir o efeito de amaciamento ("running in"), ficando o material pronto com um a rugosidade $\mathrm{Ra}$ entre 6 e $12 \mu \mathrm{m}$ (mesmo assim, os tempos de amaciamento foram bastante altos).

As dimensões dos corpos-de-prova são mostradas na fig. 4.7.

Para a primeira bateria de testes foram os mesmos colados com "Araldite" a chapas de aço, que por sua vez são roscadas em pinos conforme o padrão da máquina, fig. 4.8 e 4.9. O adesivo "Araldite" é usado em colagens a frio de lonas. Para uma maior durabilidade e confiabilidade da colagem em serviços pesados se recomenda o adesivo "3M 1099", com cura a quente em estufa. O adesivo não curado em estufa apresentou problemas de descolar nos testes e 
na segunda fase dos testes (alta velocidade) foram montados de maneira diferente.

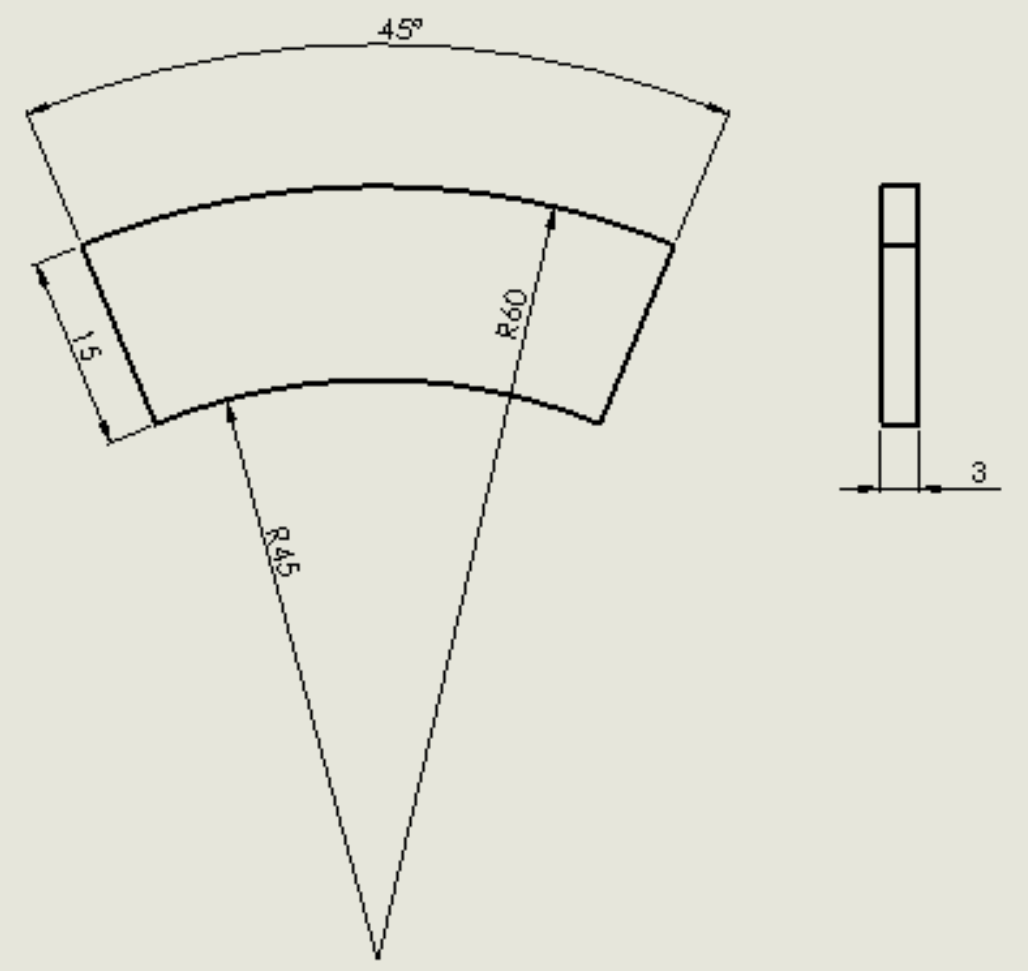

Figura 4.7: Corpo de prova - Iona
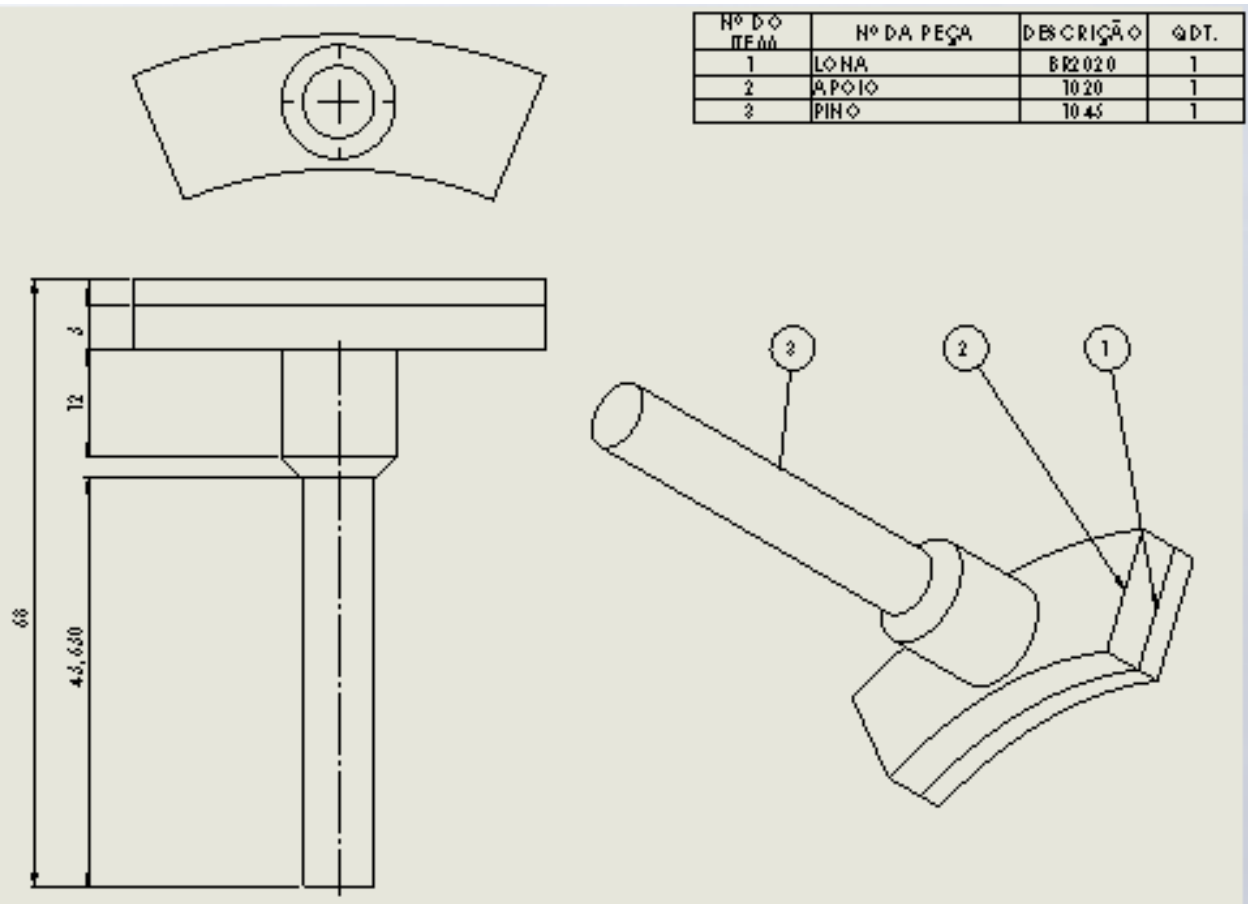

Figura 4.8: Montagem corpo de prova. 


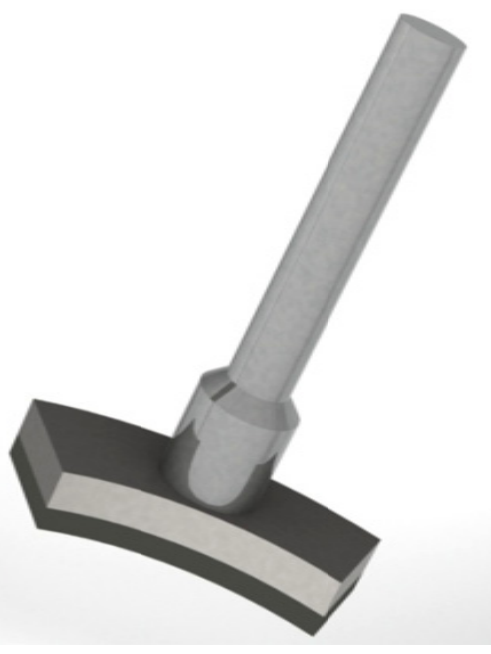

Figura 4.9: Montagem do corpo de prova colado.

Para as outras baterias de testes, optou-se por outro suporte do corpo de prova como mostrado na figura 4.10 , onde se encaixa a lona a ser ensaiada.

Essa nova montagem mostrada na figura 4.11 evita os problemas de descolamento da lona, que muitas vezes interrompiam os ensaios prematuramente, e permite a rápida remoção da lona para sua pesagem, permitindo a avaliação da taxa de desgaste.
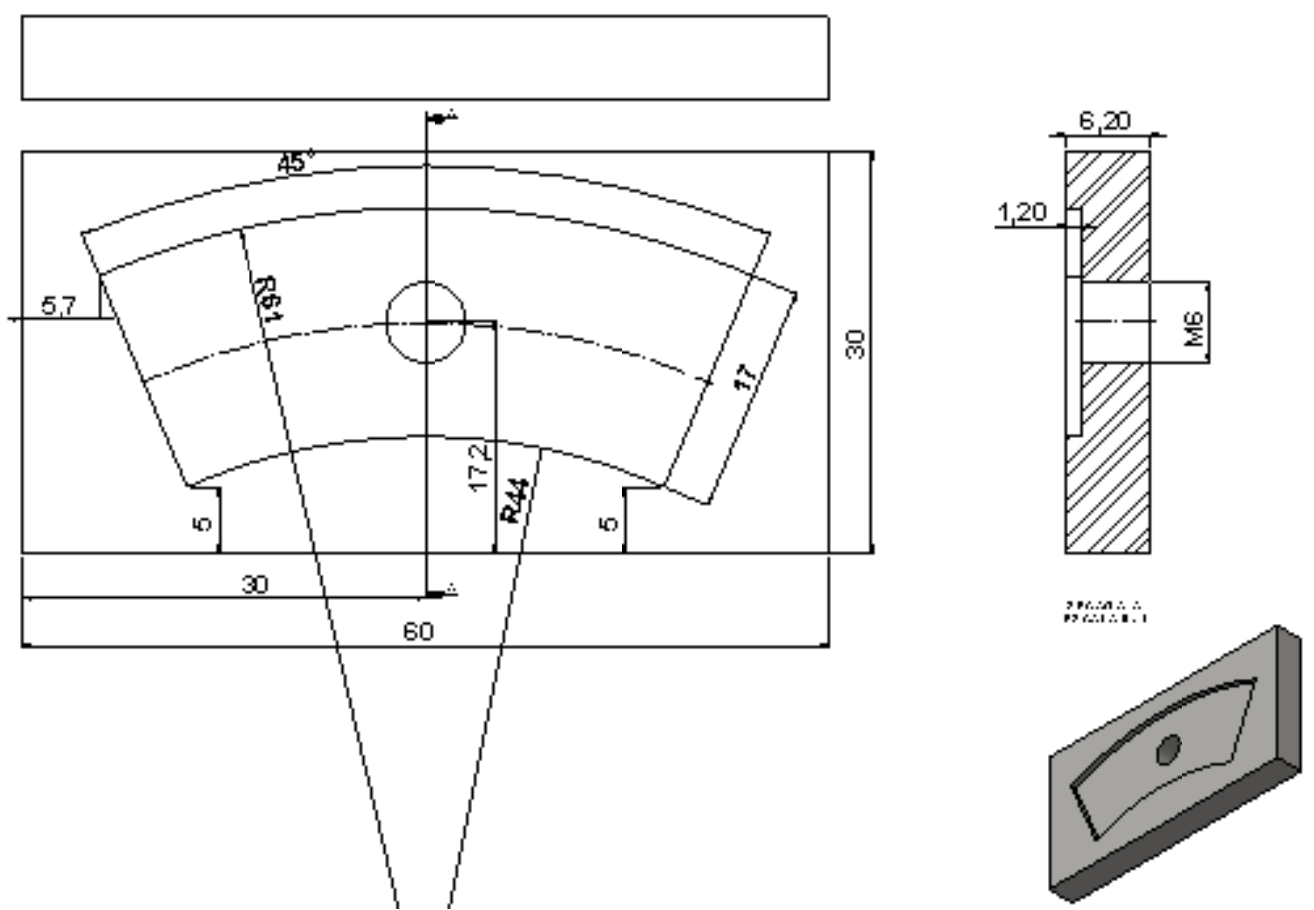

Figura 4.10: Suporte para encaixe da lona. 


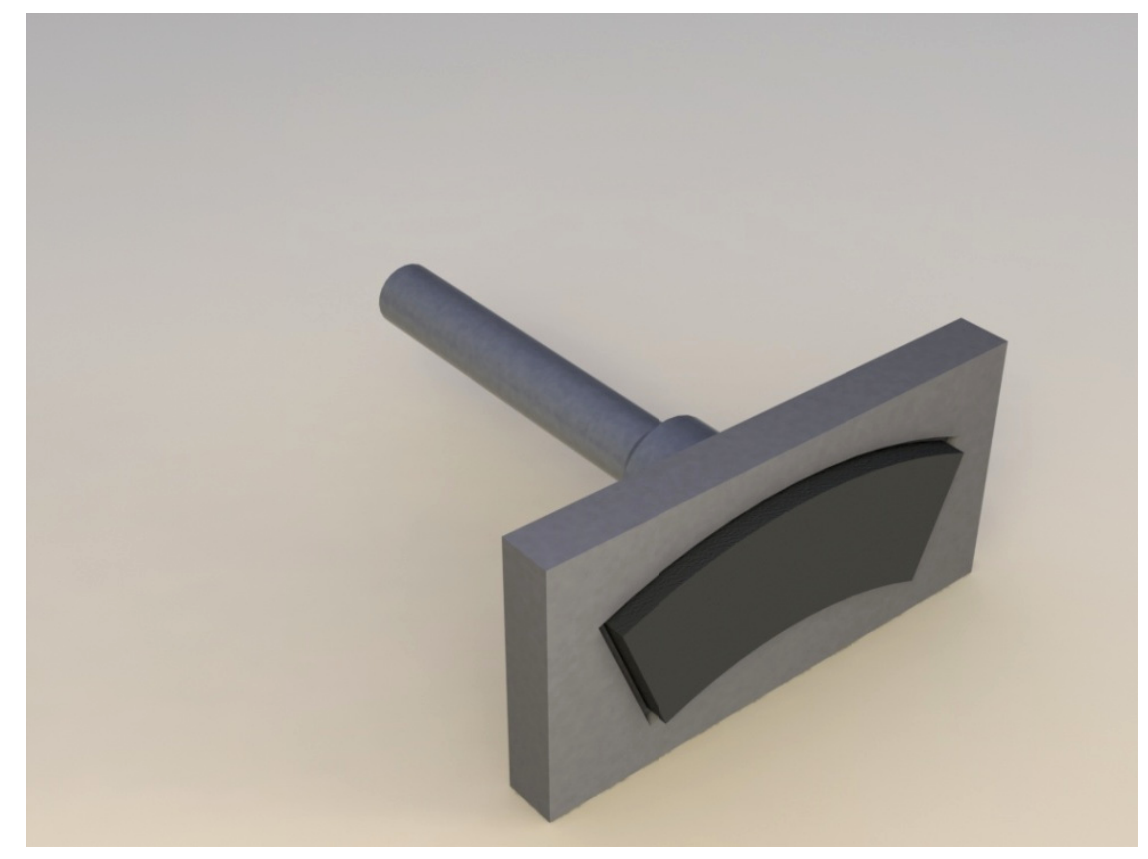

Figura 4.11: Nova montagem do corpo de prova.

Os contra-corpos em ferro fundido cinzento FC300 comercial foram usinados nas medidas apresentadas na fig. 4.12.

Suas características principais são:

Conforme norma ABNT NBR 6589 FC300

densidade

$7200 \mathrm{~kg} / \mathrm{m}^{3}$,

dureza

197 a $269 \mathrm{HB}$

resistência a tração

$230 \mathrm{MPa}(\mathrm{min}$.

O acabamento superficial dos contra-corpos procurou simular o encontrado nos equipamentos. Após a usinagem de acabamento os discos foram lixados em duas etapas. Após cada ensaio o contra-corpo foi novamente lixado para atingir essa rugosidade e retirar qualquer filme de transferência que se tenha formado. As figuras 4.13 e 4.14 apresentam a microestrutura de dois contra-corpos em diferentes estágios de usinagem. O contra-corpo da fig. 4.13 é apenas usinado e o da fig. 4.14 é com o acabamento final. A figura 4.15 é a ampliação da fig. 4.14 e a figura 4.16 é a micrografia do contra corpo da fig. 4.13. 


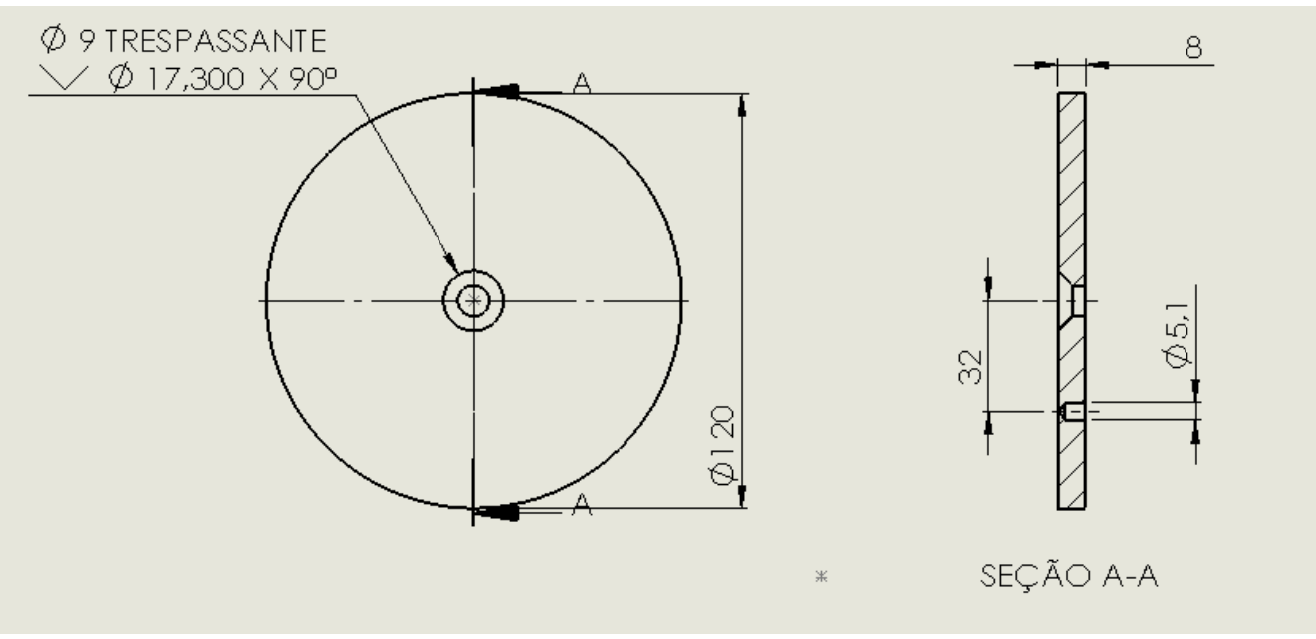

Figura 4.12: Contra corpo

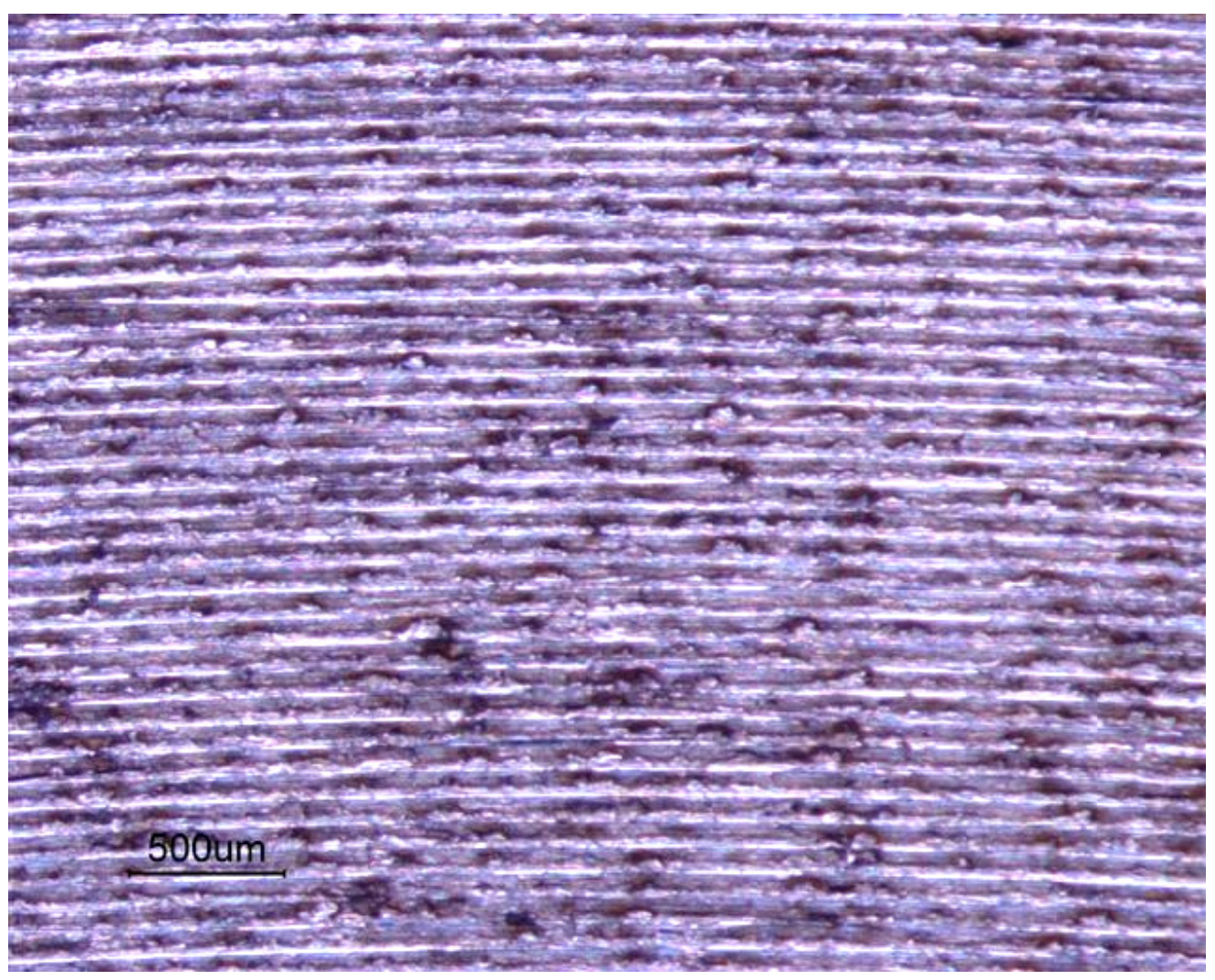

Figura 4.13: Foto de um contra-corpo (sem acabamento) 


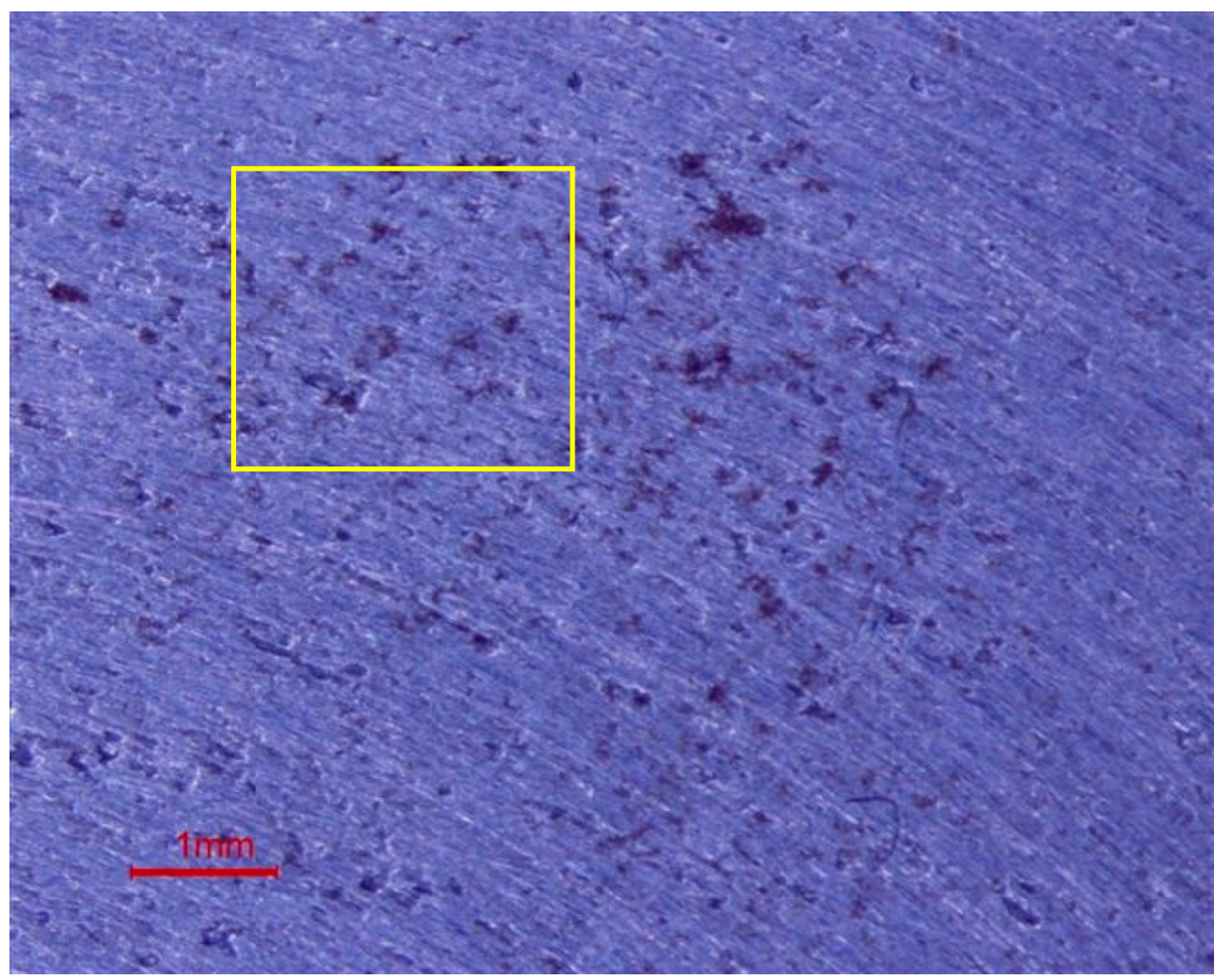

Figura 4.14: Foto de um contra-corpo

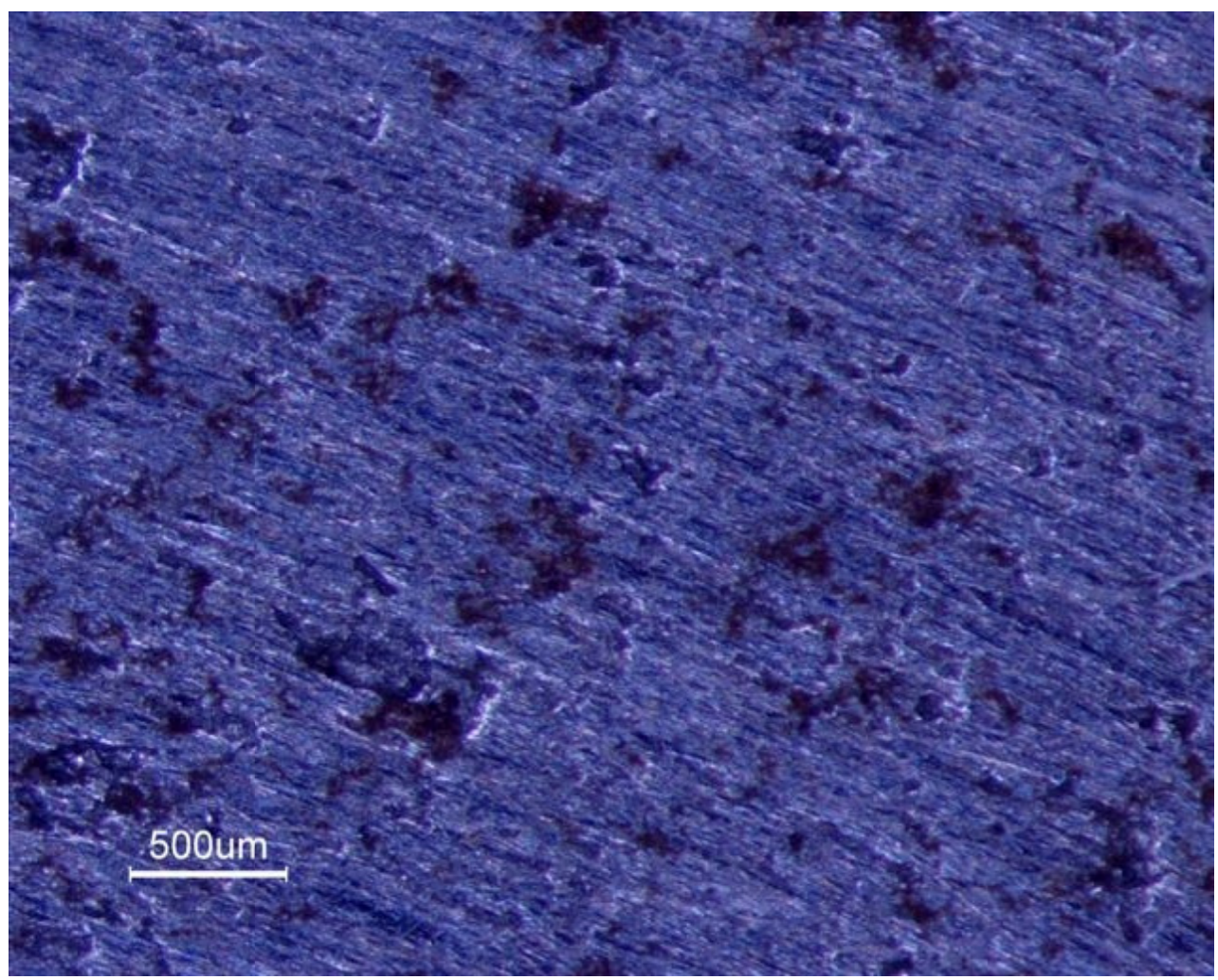

Figura 4.15: Ampliação da fig. 4.14 


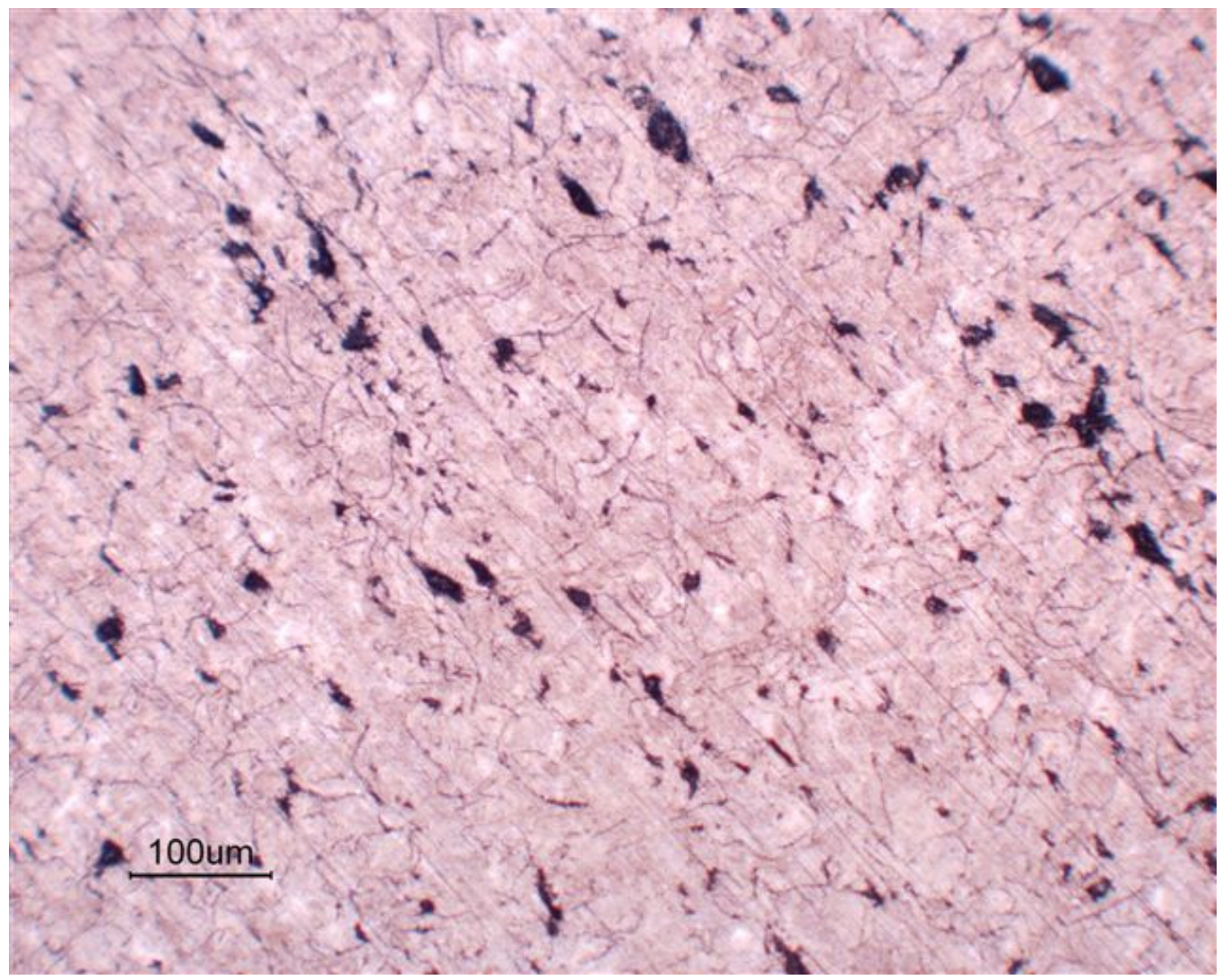

Figura 4.16: Micrografia do contra-corpo fig. 4.13

\subsection{1- ENSAIO DE CONTATO CONSTANTE:}

Esses ensaios têm como objetivo levantar a curva coeficiente de atrito versus distância para pares de velocidade e pressão usualmente encontrados em freios e embreagens de prensas.

Basicamente o pino é baixado a uma força normal constante e o contra corpo gira a uma velocidade constante. O equipamento mede o torque necessário de contra corpo, de onde se obtêm o coeficiente de atrito.

Com base nas limitações do equipamento e nas condições de operação de prensas se definem as condições de ensaio constantes na tabela 4.1 para os a primeira bateria de ensaios (menos de 1000 RPM).

Tabela 4.1: Condições da primeira bateria de ensaios.

\begin{tabular}{|l|c|c|c|c|c|c|c|}
\hline FORÇA APLICADA (N) & 100 & 200 & 100 & 200 & 250 & 100 & 100 \\
\hline ROTAÇÃO (rpm) & 100 & 100 & 500 & 500 & 500 & 750 & 1500 \\
\hline PRESSÃO DE CONTATO (bar) & 1,650 & 3,300 & 1,650 & 3,300 & 4,125 & 1,650 & 1,650 \\
\hline VELOCIDADE MÉDIA (m/s) & 0,17 & 0,17 & 0,85 & 0,85 & 0,85 & 1,28 & 2,55 \\
\hline
\end{tabular}


Para a segunda bateria de ensaios, podemos ter as seguintes condições de ensaio, sendo bem próximas às condições (pressão de contato e velocidade média) de operação de prensas mecânicas (Tabela 4.2).

Tabela 4.2: Condições de ensaio da segunda bateria.

\begin{tabular}{|l|c|c|c|}
\hline FORÇA APLICADA (N) & 60 & 180 & 240 \\
\hline PRESSÃO CONTATO (bar) & 0,990 & 2,970 & 3,960 \\
\hline ROTAÇÃO (rpm) & 1000 & 1000 & 1000 \\
\hline VELOCIDADE MÉDIA (m/s) & 1,70 & 1,70 & 1,70 \\
\hline
\end{tabular}

A aquisição de dados foi feita pelo próprio equipamento de ensaio. A aquisição das temperaturas, medidas por um termopar montado no suporte do corpo de prova, também foi feita pelo equipamento de ensaio. 


\section{5- RESULTADOS EXPERIMENTAIS E DISCUSSÕES}

\section{1 - PERDAS DE MASSA POR DEGRADAÇÃO}

As lonas comerciais apresentam na maioria dos casos limites de temperatura de trabalho entre $200{ }^{\circ} \mathrm{C}$ e $250{ }^{\circ} \mathrm{C}$ e temperaturas máximas um pouco acima de $300{ }^{\circ} \mathrm{C}$. Esses limites estão relacionados com a degradação da base polimérica do compósito que a lona é fabricada. Para comprovar esse fato foram feitos ensaios simples das lonas usadas na embreagem da fig. 1.1. Os resultados obtidos são mostrados na fig. 5.1.

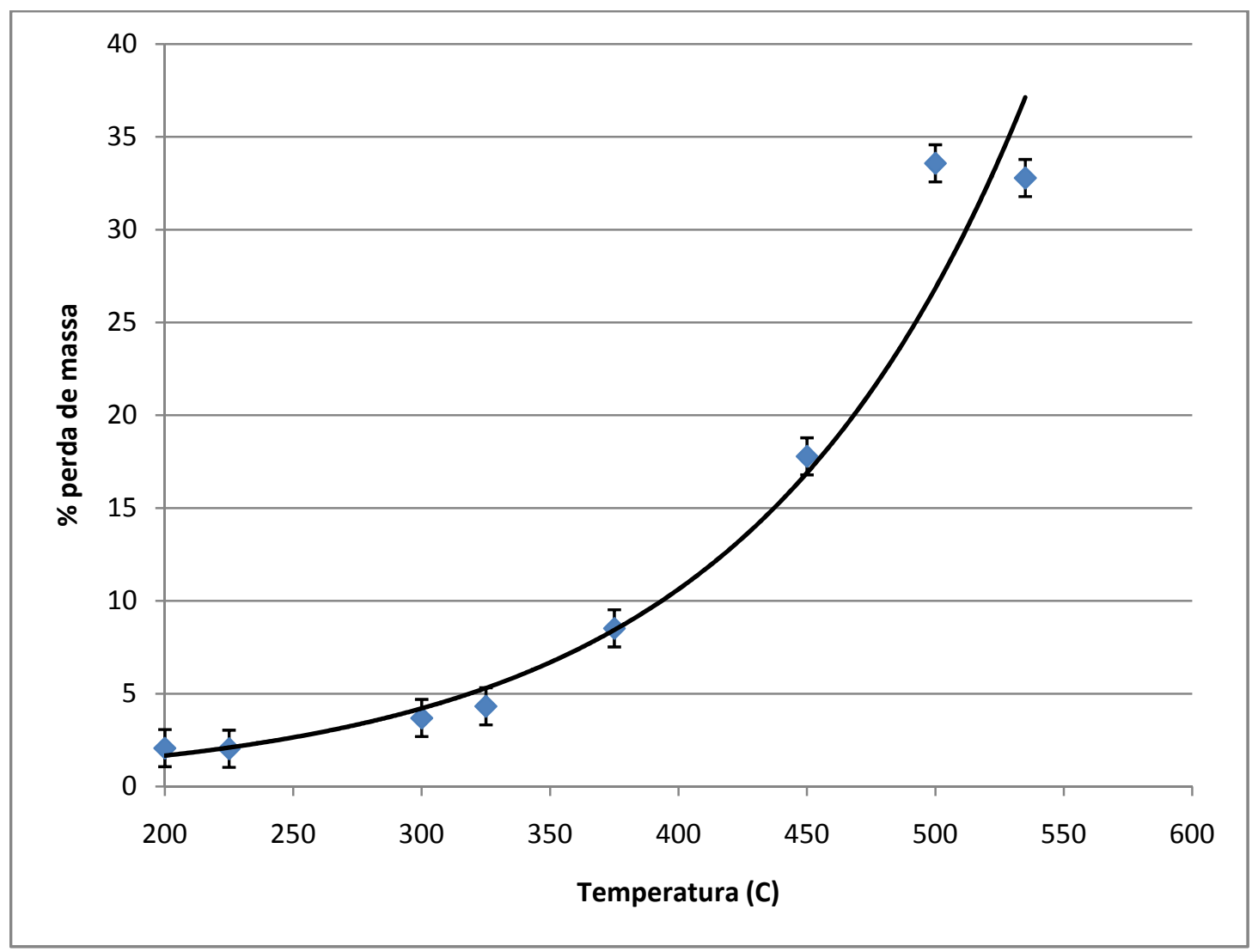

Fig. 5.1: Perda de massa nos ensaios de forno

Esses resultados de perda de massa comprovam a relação dos limites de temperatura encontrados em catálogos comerciais, com a degradação da matriz fenólica (normalmente entre 200 e 300 graus, conforme a resina). 


\section{2- PRÉ-ANÁLISE DO PROBLEMA POR SIMULAÇÃO}

Para uma previsão preliminar das temperaturas na face da lona foram feitos dois compósitos imaginários e se simularam algumas análises térmicas. Foi um modelo para uma avaliação qualitativa. A razão dessa análise qualitativa é ter uma idéia de como poderão se comportar os materiais nos ensaios e quais fatores ligados à temperatura possam ser significativos. O modelo simples de simulação empregado não irá prever o desgaste ou degradação, porém as temperaturas calculadas indicam as regiões onde teremos perda de massa por degradação.

Para o primeiro modelo usou-se uma matriz polimérica e abrasivos de $1 \mathrm{~mm}$ de diâmetro. O compósito está apoiado em uma placa de aço, de maneira semelhante à montagem usual, fig. 5.2.

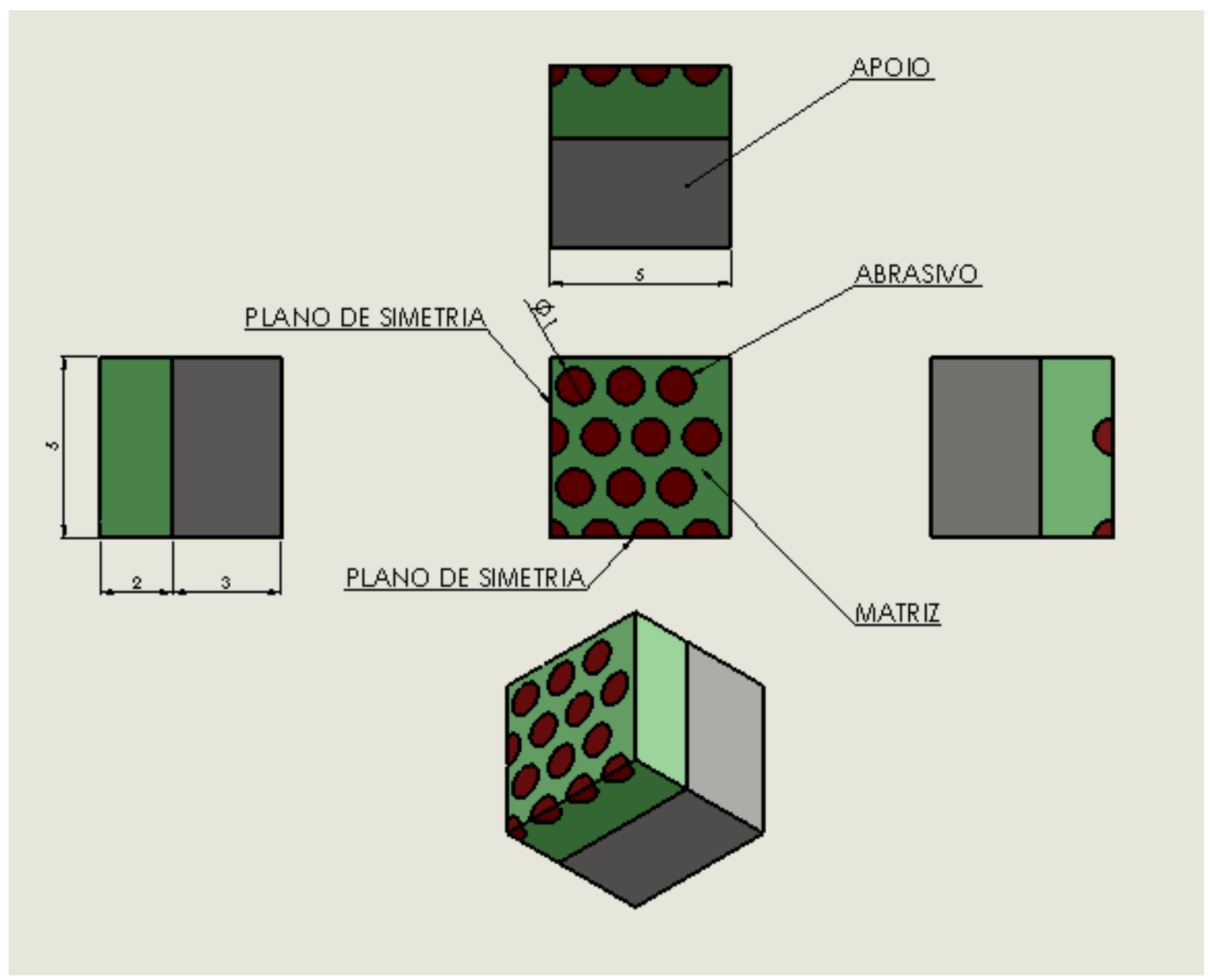

Figura 5.2: Modelo de compósito 
Foram aplicadas cargas térmicas de convecção a de $24 \mathrm{~W} /\left(\mathrm{m}^{2} \mathrm{x}{ }^{0} \mathrm{~K}\right)$ a uma temperatura de referência de $300{ }^{\circ} \mathrm{K}$ (que foram as mesmas aplicadas no Projeto da UC 1600), fig. 5.3. Sua localização procura imitar as trocas existentes nos equipamentos, o apoio troca na sua parte superior e em uma face lateral (que seria a face externa da lamela). A lona troca em duas laterais (duas são de simetria) imitando a troca com a face externa e a face entre lonas. Para se estimar o calor adicionado ao sistema utilizou-se o trabalho realizado por forças de atrito geradas por pressões de contato de 2,3 e $4 \mathrm{kgf} / \mathrm{mm}^{2}$, distância de escorregamento de $200 \mathrm{~mm}$ e coeficiente de atrito utilizado foi de 0,40 (usual entre lonas).

No modelo feito têm-se uma área de contato total de $25 \mathrm{~mm}^{2}$, sendo $19,5 \mathrm{~mm}^{2}$ de polímero e $5,5 \mathrm{~mm}^{2}$ de abrasivo, procurando ter uma composição volumétrica dentro das faixas usuais.

Foram usadas duas placas de apoio com espessuras diferentes ( $3 \mathrm{~mm}$ e 1,5 $\mathrm{mm}$ ) para uma avaliação da influência da troca térmica do suporte na temperatura máxima do compósito.

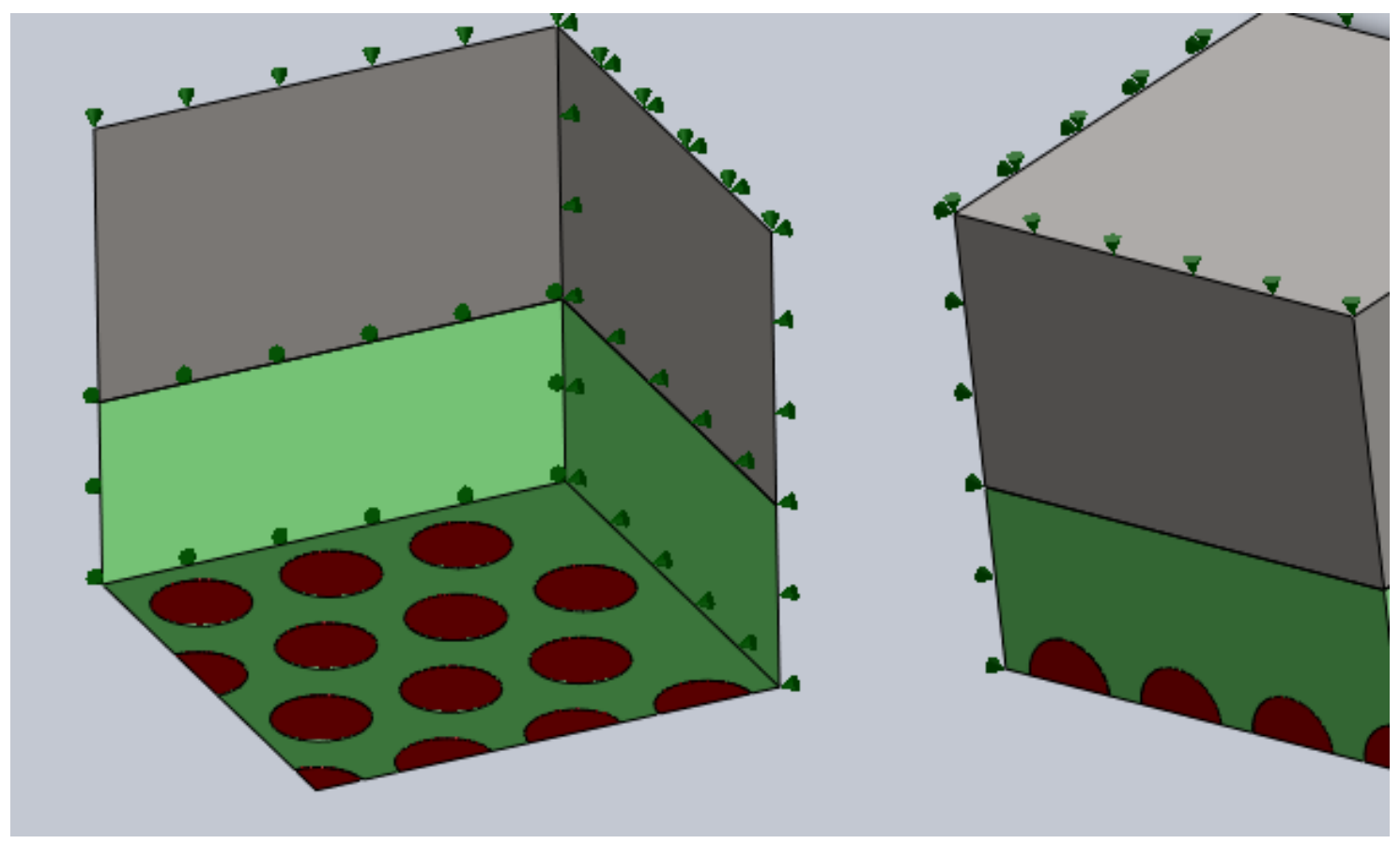

Figura 5.3: Cargas de convecção

Simulou-se com tempos de inserção de 20, 10, 6, 4 e 2 s. Então com pressão e área obtêm-se a força normal e com $\mu$, obtêm-se a força de atrito. Com a 
distância obtêm-se o trabalho de atrito e o calor gerado por cada inserção. Com a quantidade de inserções define-se o fluxo médio de calor aplicado ao compósito, aplicado proporcionalmente, ao coeficiente de atrito de polímero e abrasivo, define-se o fluxo de calor por elemento.

O segundo compósito tem as mesmas dimensões que o primeiro, o calor adicionado ao sistema é idêntico ao primeiro, a área de abrasivos na face das lonas são idênticas. Para se manter essa relação usou-se um diâmetro de $0,414 \mathrm{~mm}$ para o abrasivo e uma distribuição de abrasivos semelhante ao primeiro, apenas com maior número de abrasivos.

Como exemplo os resultados da simulação para 10 inserções por minuto com 2 $\mathrm{kgf} / \mathrm{cm}^{2}$ de pressão estão mostrados na fig. 5.4 para o caso de abrasivos maiores e na fig. 5.5 para o caso de abrasivos menores.

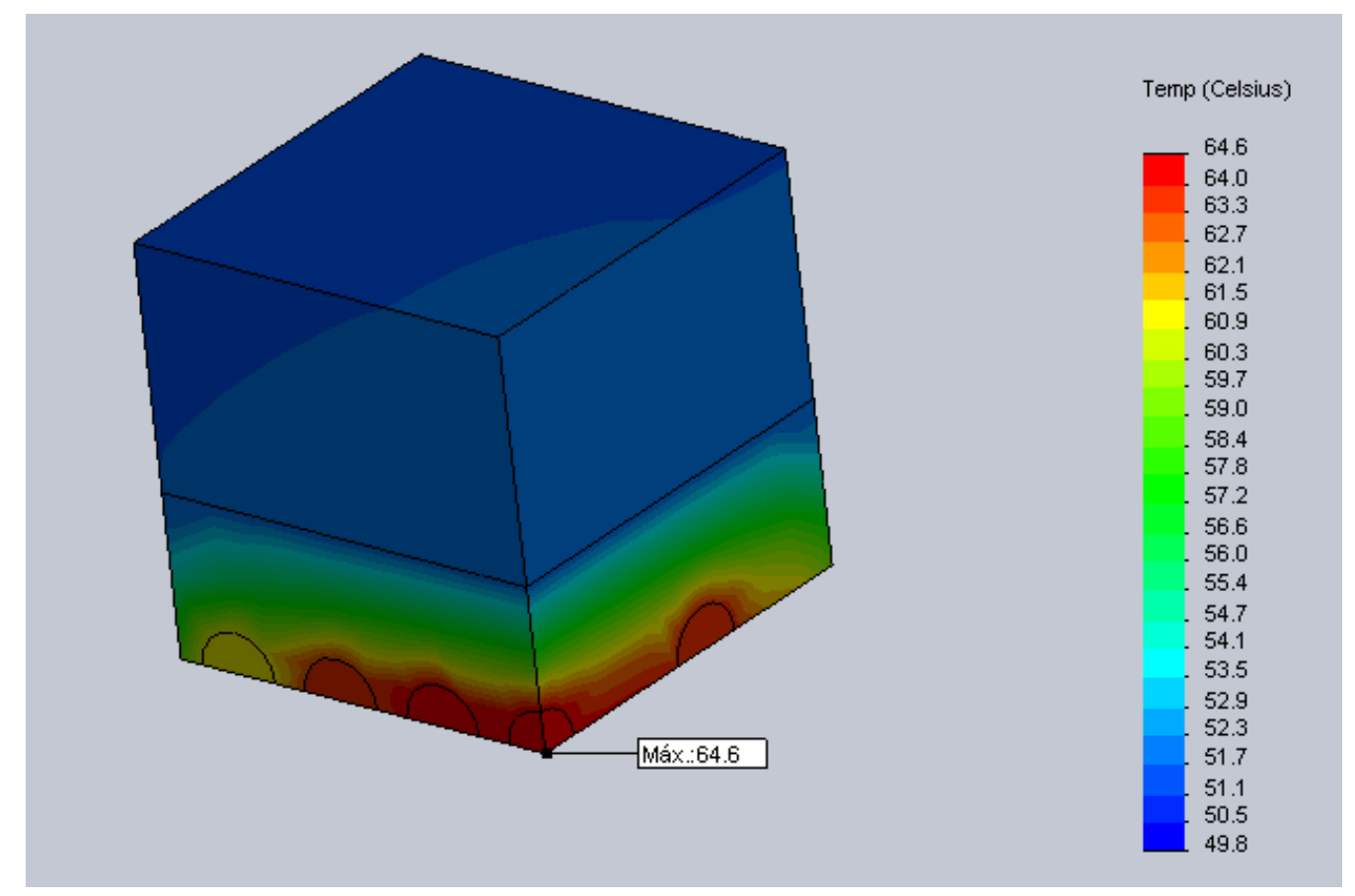

Figura 5.4: Análise térmica para inserções espaçadas em $10 \mathrm{~s}$ e $200 \mathrm{kPa}$, modelo com abrasivos maiores.

As fig. 5.6 e fig. 5.7 mostram em detalhe a região de contato e o aquecimento em torno dos abrasivos, para ambos os casos, é um regime de baixa solicitação da embreagem e as temperaturas se mantêm baixas. Existe gradiente de temperatura do centro para a periferia em função da troca térmica. Em outro modelo notou-se que fibras condutoras de calor (latão) tendem a 
diminuir o gradiente de temperatura, mostrando a razão da aplicação de fibras de latão na maioria das embreagens industriais.
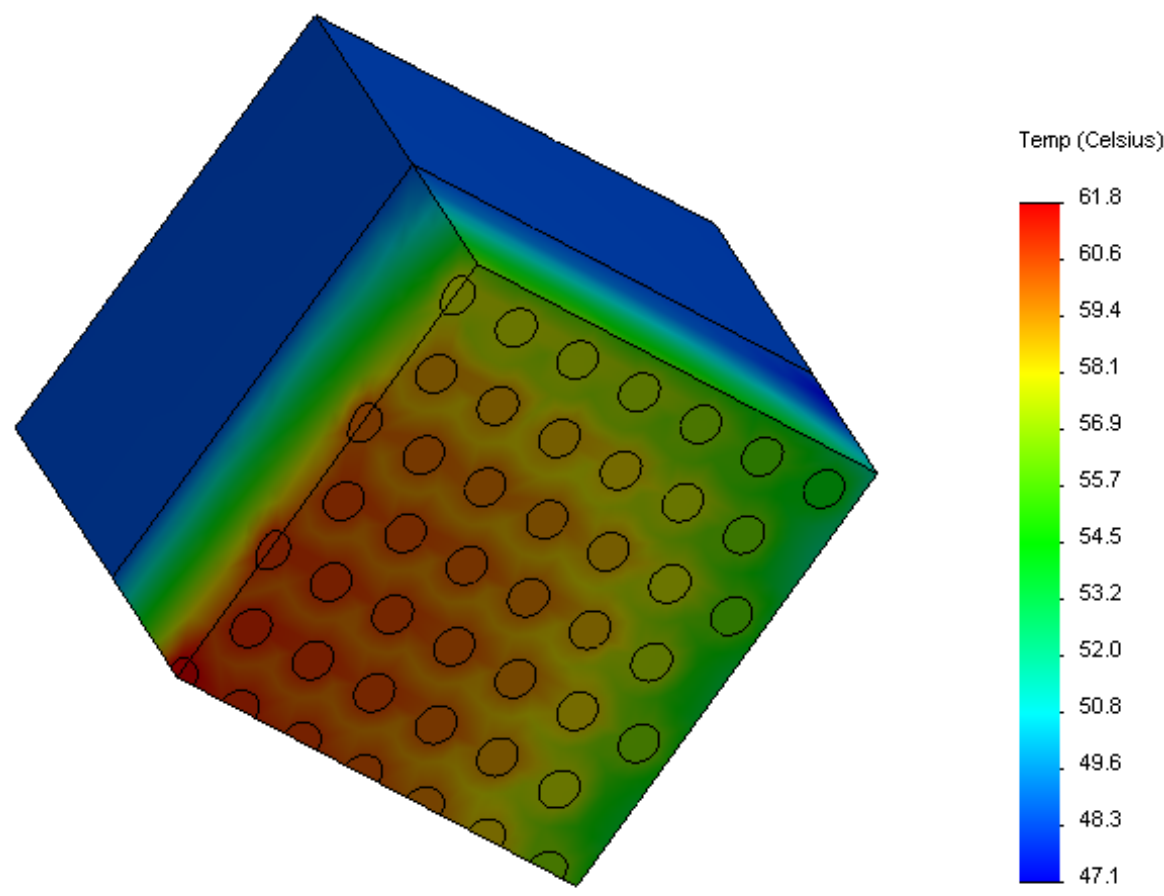

Figura 5.5: Análise térmica para inserções espaçadas em 10 s e 200 kPa, modelo com abrasivos menores.

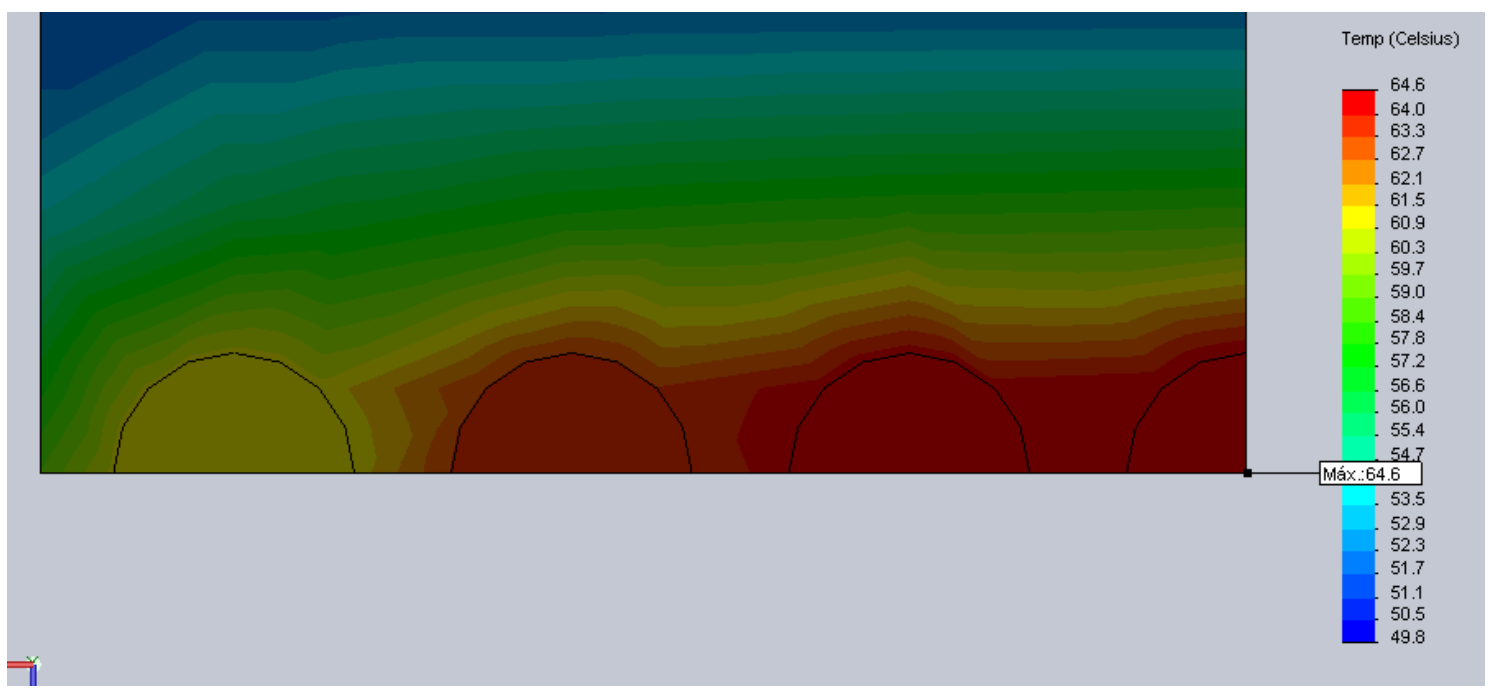

Figura 5.6: Detalhe da figura 5.4. 


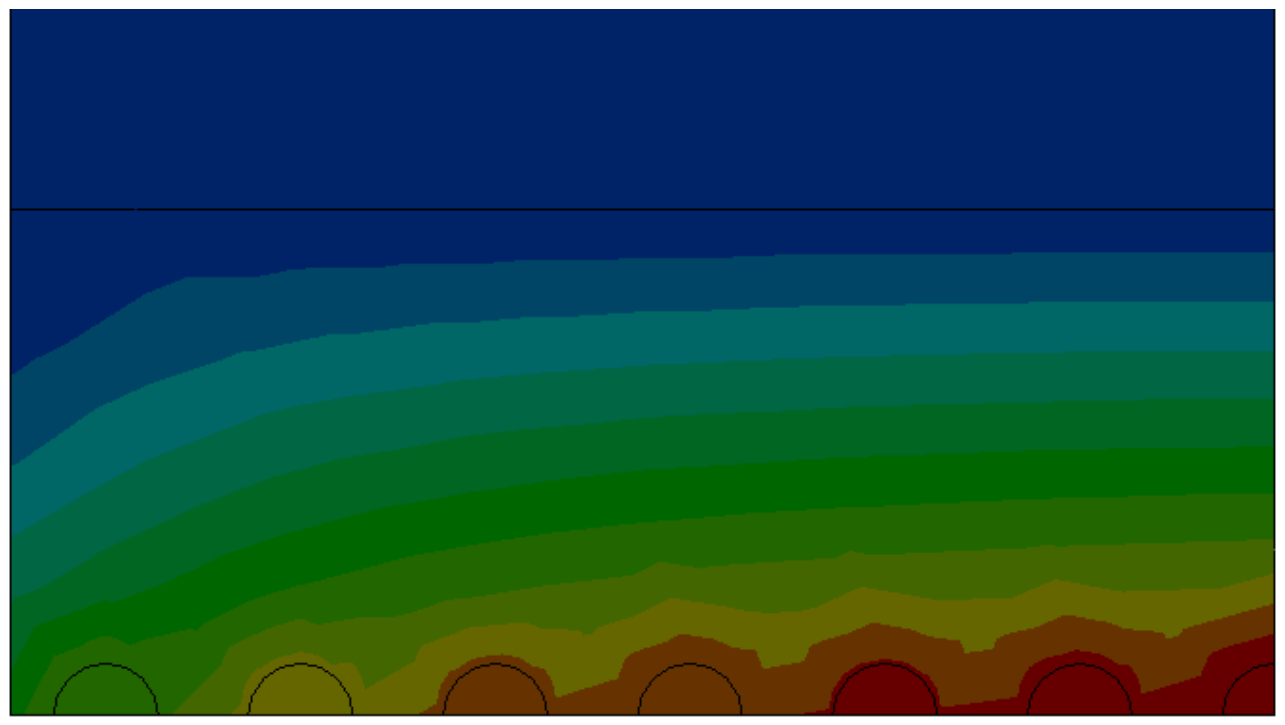

Figura 5.7: Detalhe da figura 5.5.

Outro exemplo: os resultados da simulação para 4 inserções por minuto com $400 \mathrm{kPa}$, são mostrados na fig. 5.8, notar a escala diferente de temperaturas (aproximadamente 4 vezes maiores).

$\mathrm{Na}$ fig. 5.9 pode-se observar o aquecimento próximo ao abrasivo e diminuindo conforme se afasta. Em estudos de transitório pode se acompanhar a evolução desse fenômeno.

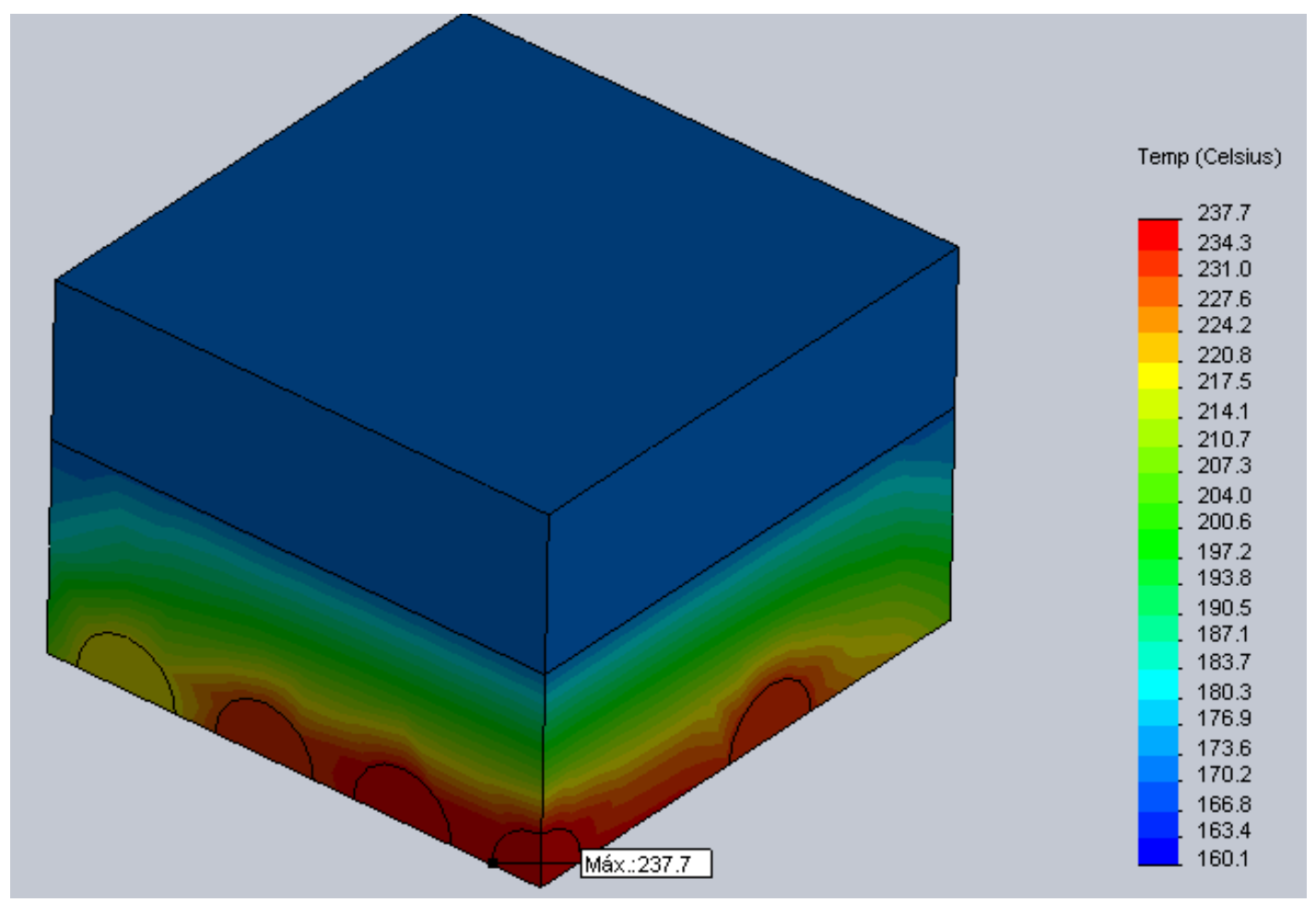

Figura 5.8: Análise térmica para 4 inserções $/$ min e 400 kPa. 


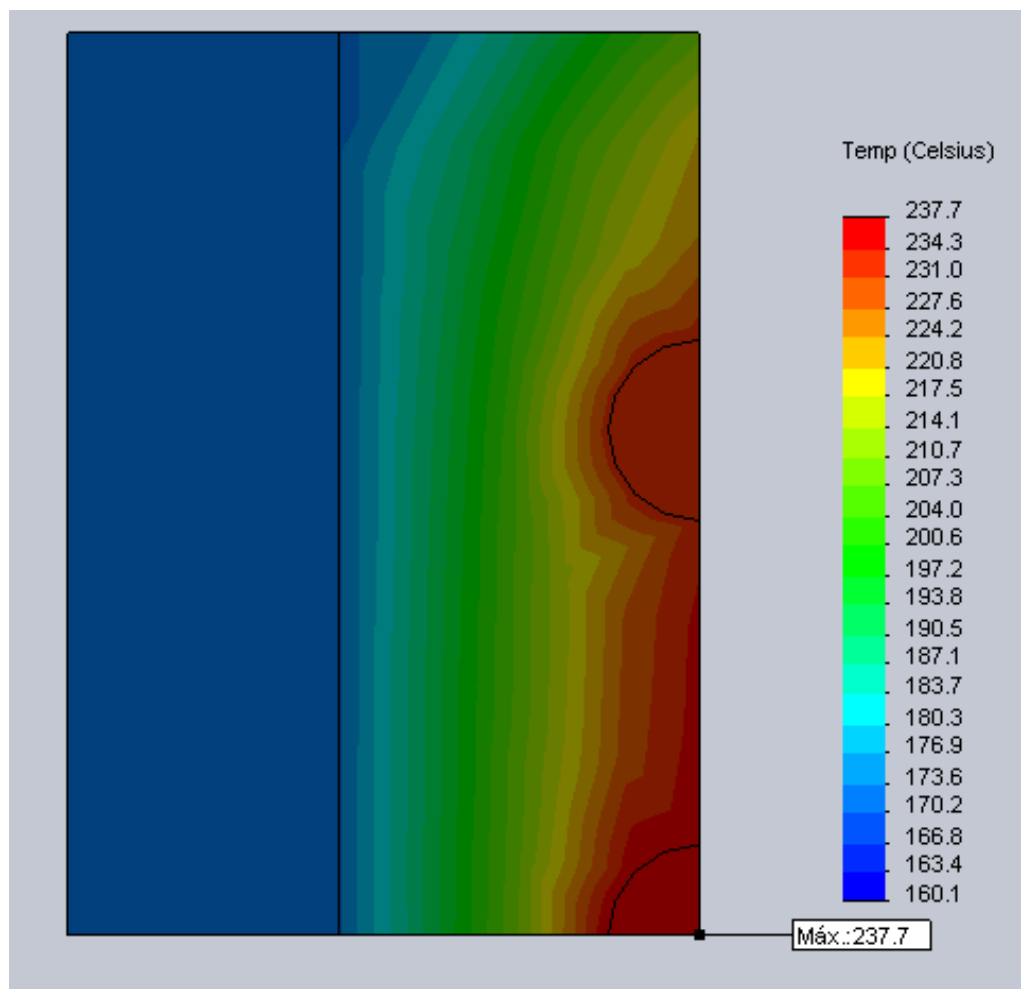

Figura 5.9: Detalhe da figura anterior

Os resultados de temperatura máxima em função do tempo entre inserções para $200 \mathrm{kPa}$ de pressão de contato estão na figura 5.10 , onde a curva azul é com a chapa de apoio maior e a curva vermelha é com a chapa de apoio menor (espessura da chapa de apoio). Nota-se que as curvas apresentam um a pouca influência da espessura do apoio.

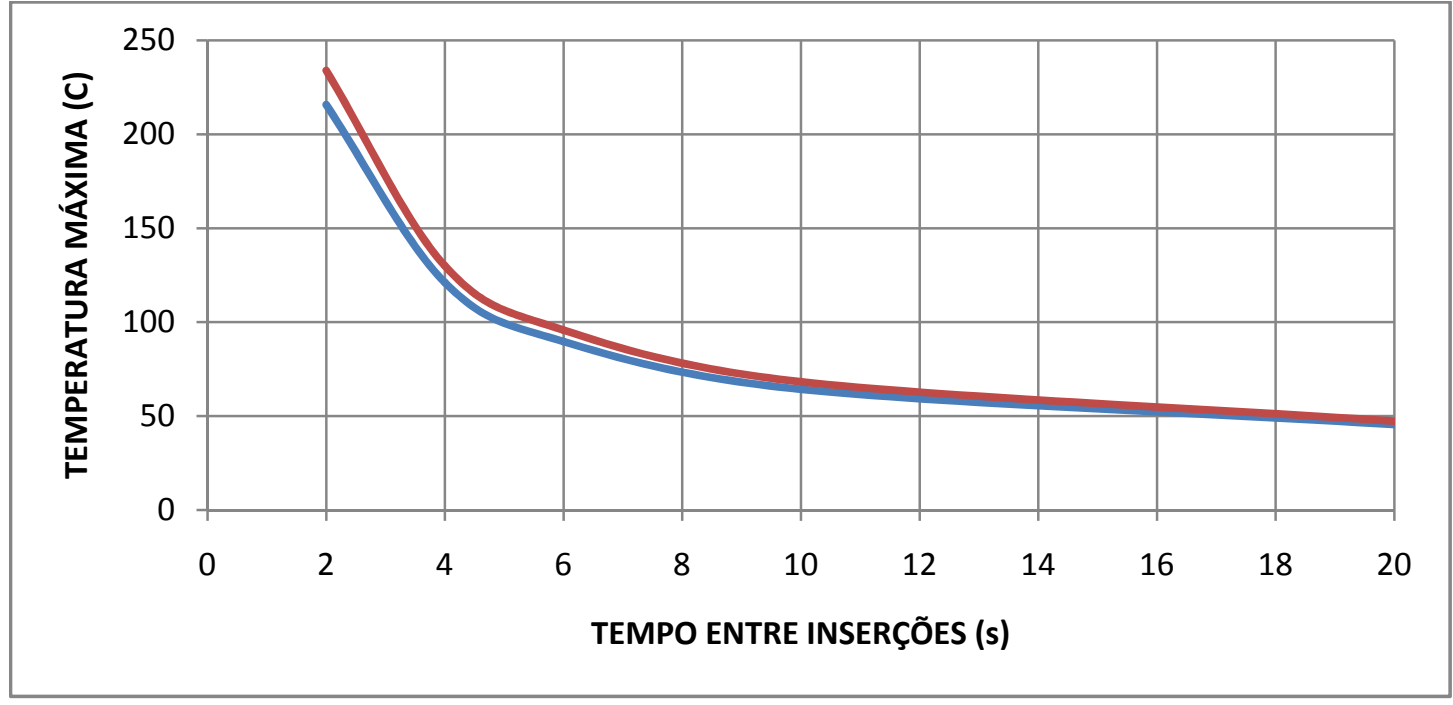

Figura 5.10: Resultados simulações para 200 kPa de pressão de contato. 
A comparação dos resultados da temperatura média da face da lona e da temperatura máxima, do Projeto da UC 1600 - Embreagem, fig. $5.11 \mathrm{com}$ os resultados para os compósitos virtuais fig. 5.12 e fig. 5.13 mostram que a temperatura média da face é igual para o compósito de abrasivo menor. As simulações foram executadas com cargas térmicas equivalentes.

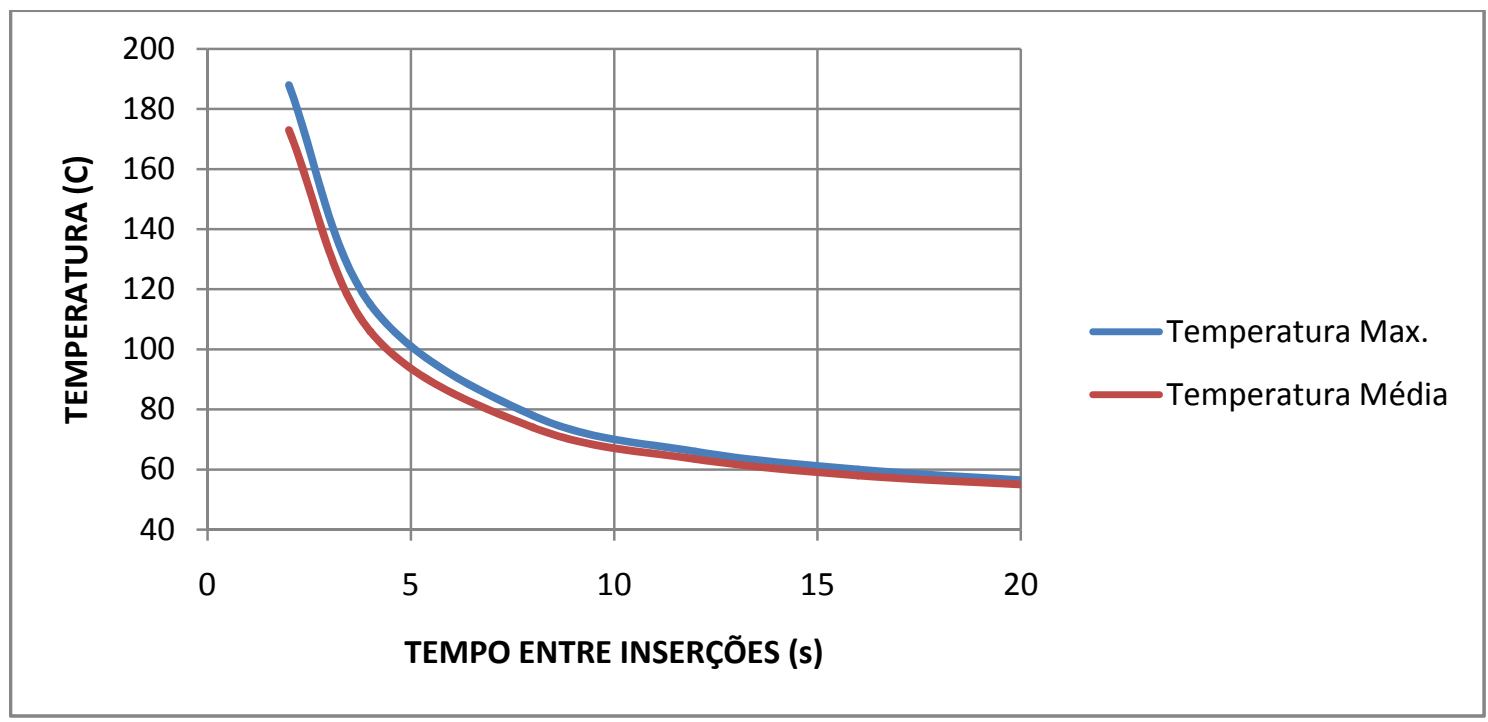

Fig. 5.11: Temperaturas máximas e médias na face da lona central da embreagem da UC 1600.

Porém se analisar as temperaturas máximas nota-se que o modelo de compósito apresenta temperaturas máximas superiores $\left(225^{\circ} \mathrm{C}\right)$ em relação à lona da embreagem $\left(190{ }^{\circ} \mathrm{C}\right)$. Tal fato e a distribuição de temperaturas apresentadas nas figuras 5.11, 5.12 e 5.13 vem a confirmar preliminarmente a hipótese apresentada.

Interessante notar, que nos três casos há um aumento significativo da temperatura a partir tempos menores que $5 \mathrm{~s}$ entre inserções. Isso se deve ao fato que o aumento do calor inserido ao sistema pelo trabalho realizado pela força de atrito suplanta o valor retirado, elevando a temperatura da embreagem até se obter o equilíbrio.

$\mathrm{Na}$ fig. 5.14 e 5.15 mostra-se o aumento da temperatura máxima para o aumento da pressão de contato em dois casos críticos (inserções a $2 \mathrm{~s}$ e a $4 \mathrm{~s}$ ). Este resultado mostra que o aumento da pressão de contato influencia diretamente as temperaturas médias e como consequência estar trabalhando 
em uma temperatura onde a perda de massa por degradação pode ser alta (como visto em 5.1), reduzindo em muito a vida das lonas.

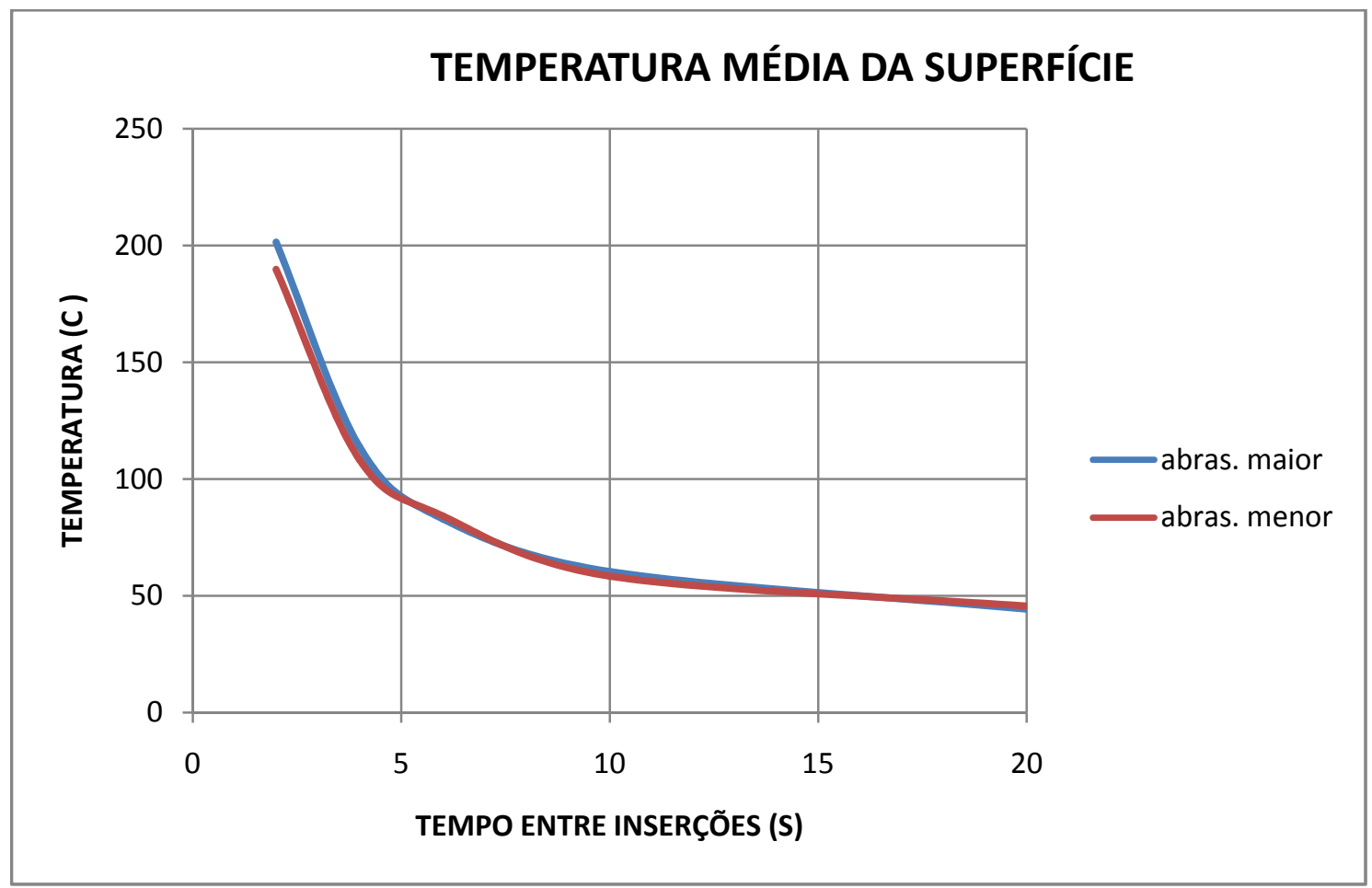

Fig. 5.12: Temperatura média na face dos compósitos virtuais.

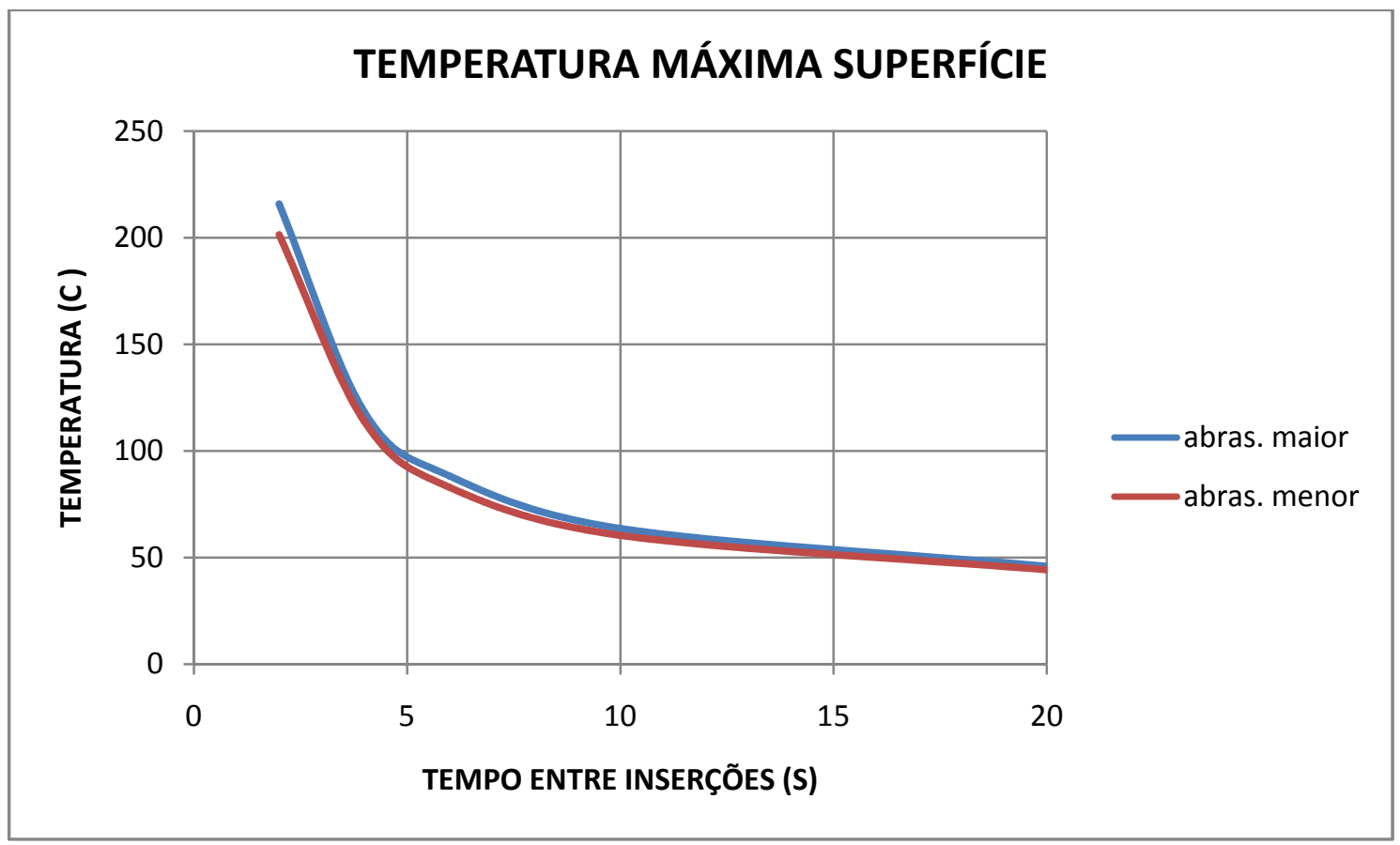

Fig. 5.13: Temperatura máxima na face dos compósitos virtuais. 


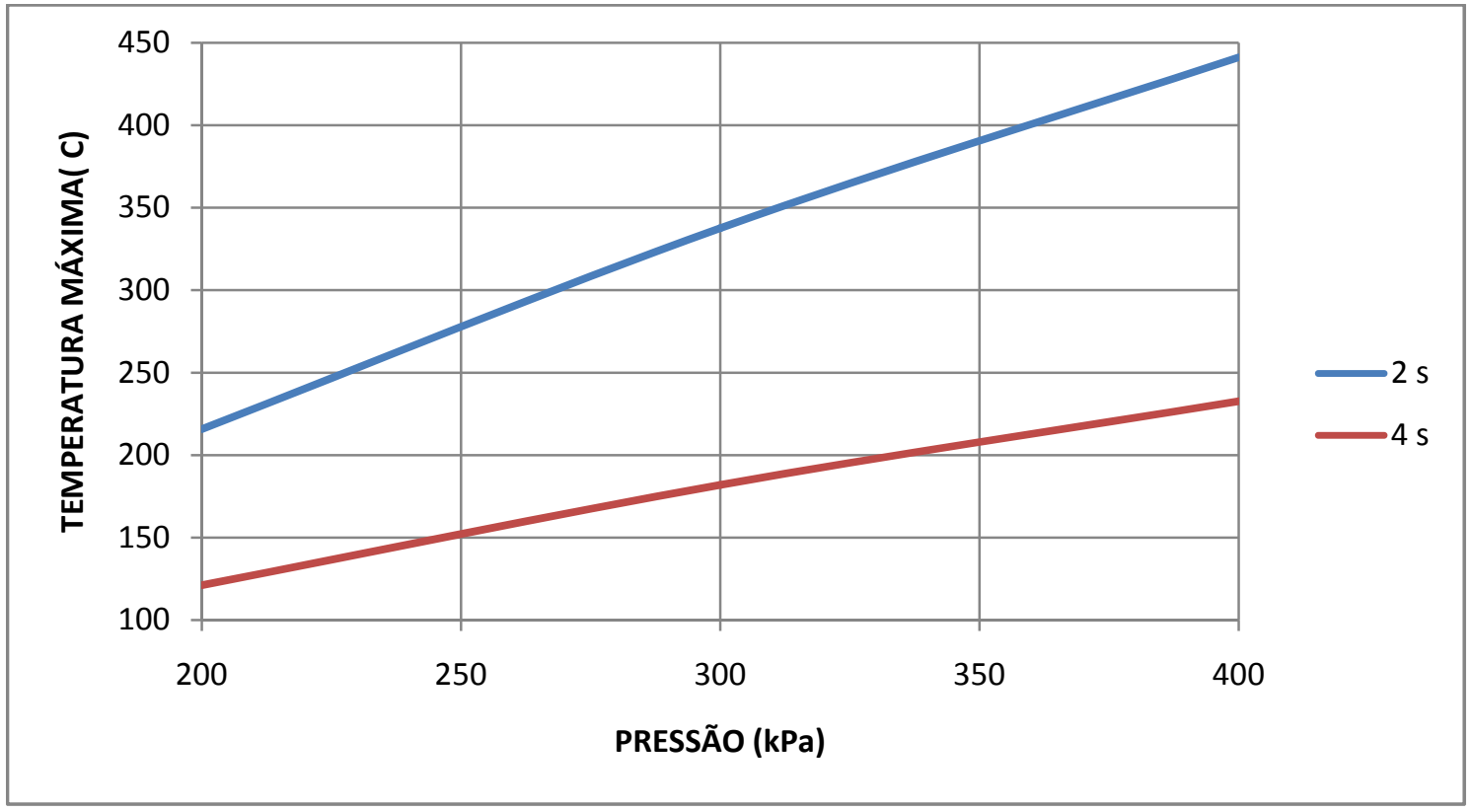

Figura 5.14: Resultados das simulações para o compósito com abrasivos maiores e tempo entre inserções de $2 \mathrm{~s}$ e $4 \mathrm{~s}$.

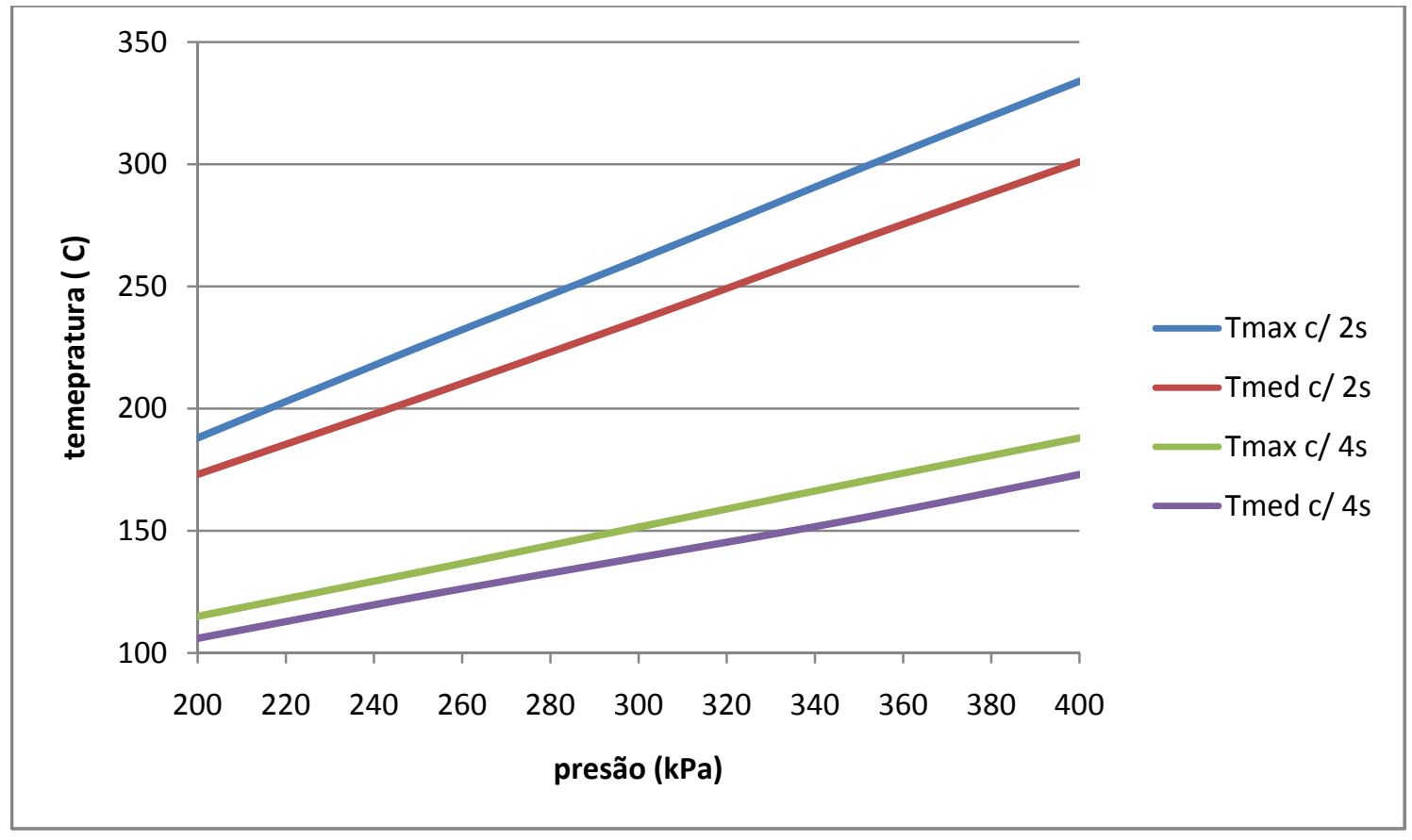

Figura 5.15: Resultados das simulações para a UC 1600 com tempo entre inserções de 2 s e $4 \mathrm{~s}$.

Enfatizando, a análise de uma lona não pode ser feita como um único corpo, mas como um conjunto de corpos unidos por um polímero (compósito). Existem 
temperaturas locais elevadas (nos abrasivos). Existe um aumento da temperatura média da lona com seu uso, implicando em redução das propriedades mecânicas do polímero. $\mathrm{O}$ desgaste não é basicamente abrasivo, há outro fator ligado a temperatura: a degradação do polímero. Para pequenos aquecimentos o entorno do abrasivo atinge temperaturas que o polímero degrada liberando-os, em aplicações mais severas o calor se transfere a uma camada superficial da lona degradando todo o polímero nessa região. As simulações por elementos finitos comprovam a existência desse gradiente no entorno do abrasivo como se pode ver nas figuras 5.4 a 5.9 de maneira semelhante à hipótese levantada, figuras 3.1 e 3.2. 


\section{3- RASGOS DE PÓ e REFRIGERAÇÃO}

Em equipamentos como conversores de torque, embreagens e freios a óleo os elementos de atrito são dotados de rasgos de refrigeração. Os rasgos de refrigeração não são encontrados em materiais não sinterizados (banho de óleo), normalmente as lonas têm faces lisas. Uma exceção conhecida são lonas utilizadas em tratores pesados onde existem rasgos na face, conhecidos como rasgos de pó.

Ortlinghaus (2006) indica valor empírico que chama de capacidade de dissipação, com os valores de 1 a $2 \mathrm{kcal} / \mathrm{cm}^{2} / \mathrm{h}$ para embreagens monodisco e 0,2 a $0,3 \mathrm{kcal} / \mathrm{cm}^{2} / \mathrm{h}$ para embreagens multidisco. Basicamente, a capacidade de dissipação é a quantidade de calor que pode ser gerada por unidade de área e tempo. Usando a faixa de valores acima foram feitas diversas simulações usando o corpo-de-prova, sem rasgos, fornecendo resultados como na fig. 5.16 e as temperaturas máximas obtidas na fig. 5.17. O que se pode ver é o cuidado que se deve ter em projeto ao utilizar valores tabelados, pois se pode chegar a temperaturas muito acima das admissíveis para o material.

Realizaram-se duas simulações com rasgos diferentes, baseadas no estudo de $0,8 \mathrm{kcal} / \mathrm{m}^{2} / \mathrm{h}$. A carga térmica por área foi aumentada de modo que a carga total seja equivalente nos três modelos, fig. 5.16, fig. 5.18 e fig. 5.19 .

No modelo com rasgos radiais a temperatura máxima diminui em $4 \%$ e no modelo com rasgos em " $X$ " diminuiu em $5 \%$. A utilização de rasgos não apresenta vantagem em relação à troca térmica, podendo apresentar vantagens em relação à retirada de resíduos.

A utilização de lonas com rasgos pode ser uma escolha viável em embreagens onde a remoção de resíduos seja problemática. No caso comum de aplicações em prensas não é o caso, já que pela montagem vertical e velocidade tangencial ocorre boa retirada de resíduos. 

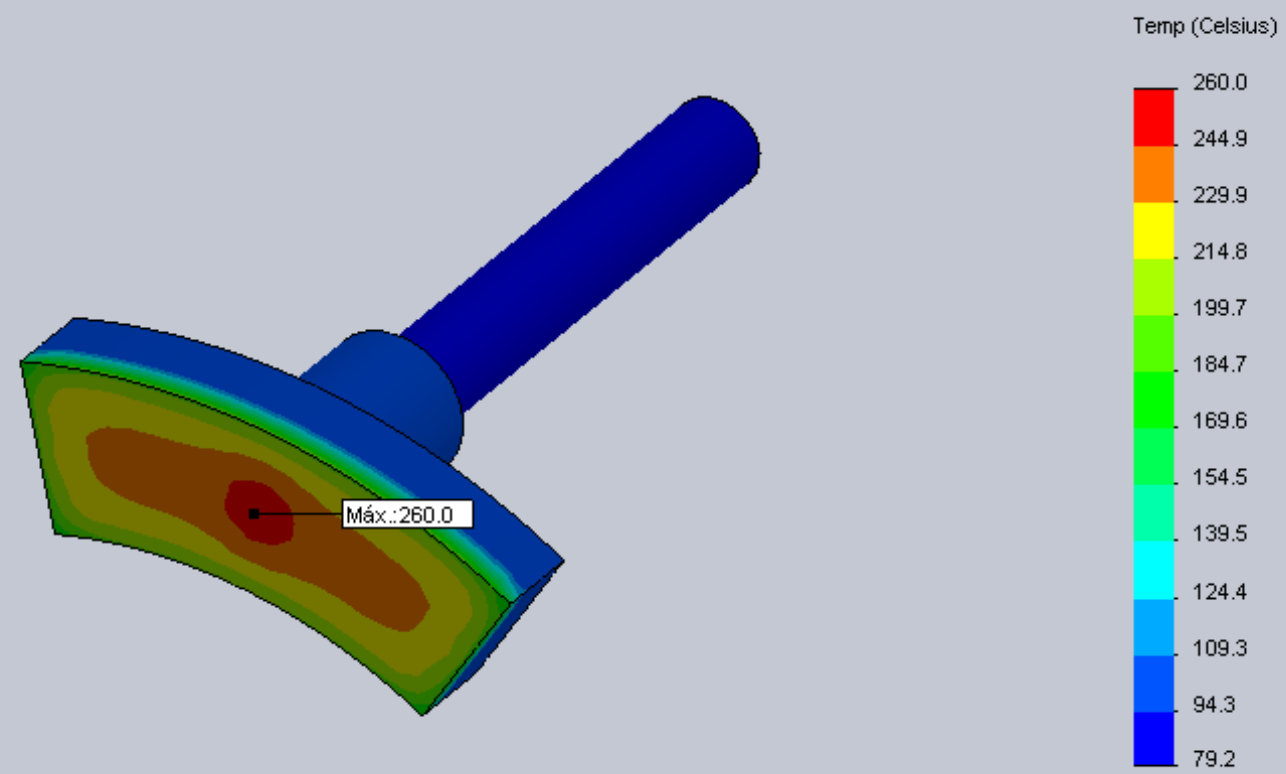

Figura 5.16: Distribuição de temperaturas para $0,8 \mathrm{kcal} / \mathrm{cm}^{2} / \mathrm{h}$, modelo sem rasgos

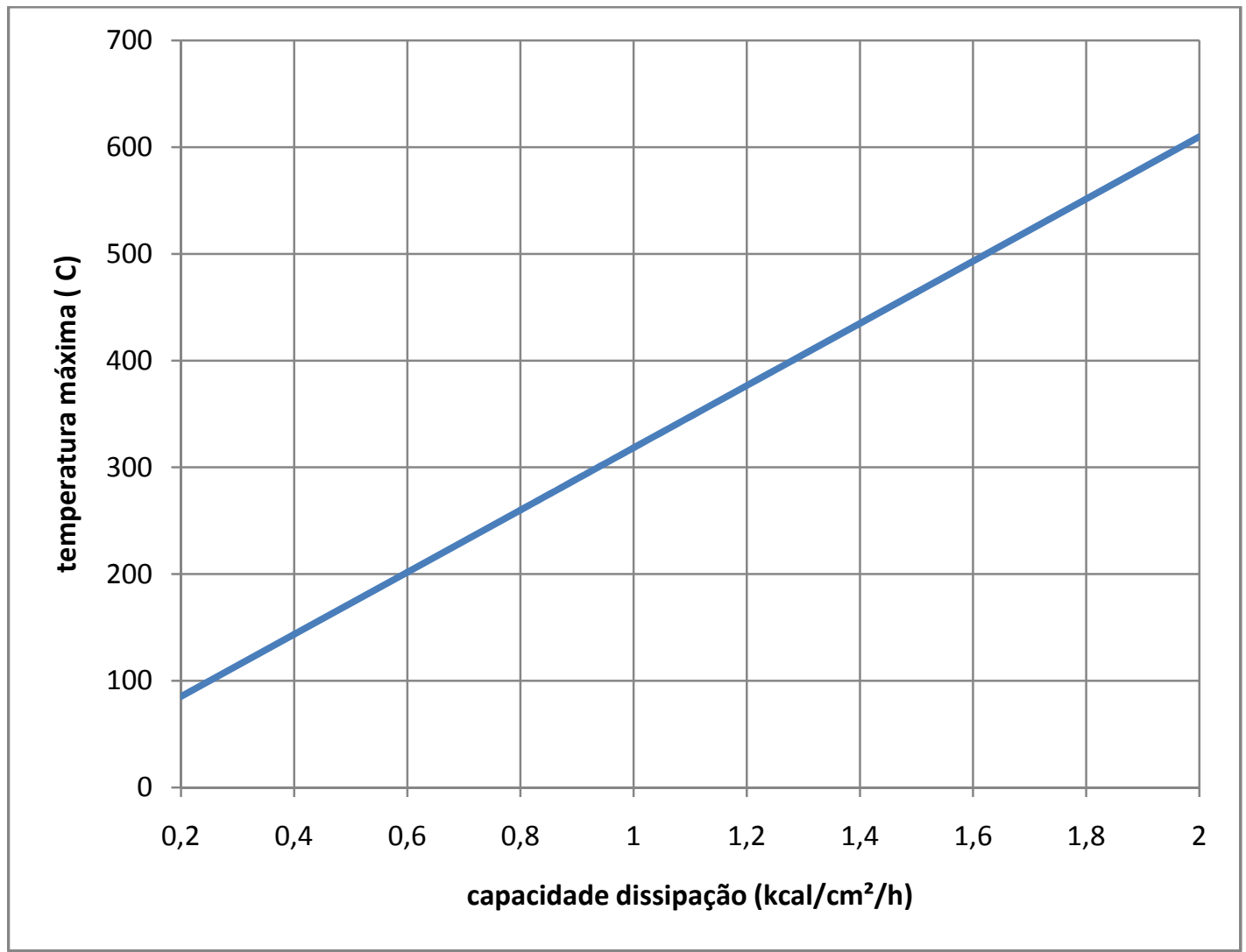

Figura 5.17: Temperatura máxima x capacidade de dissipação no modelo sem rasgos. 


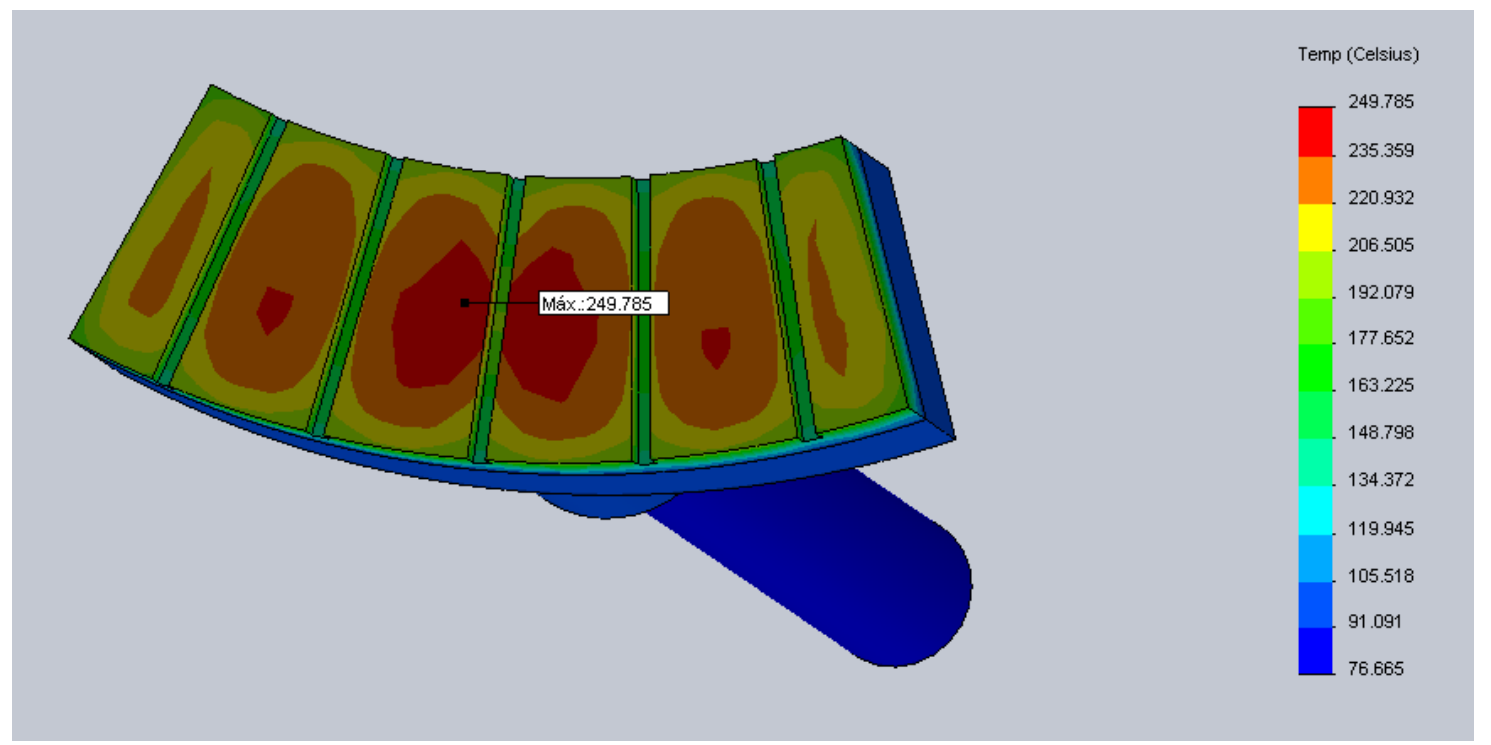

Figura 5.18: Distribuição de temperaturas para $0,8 \mathrm{kcal} / \mathrm{cm}^{2} / \mathrm{h}$, modelo com rasgos radiais

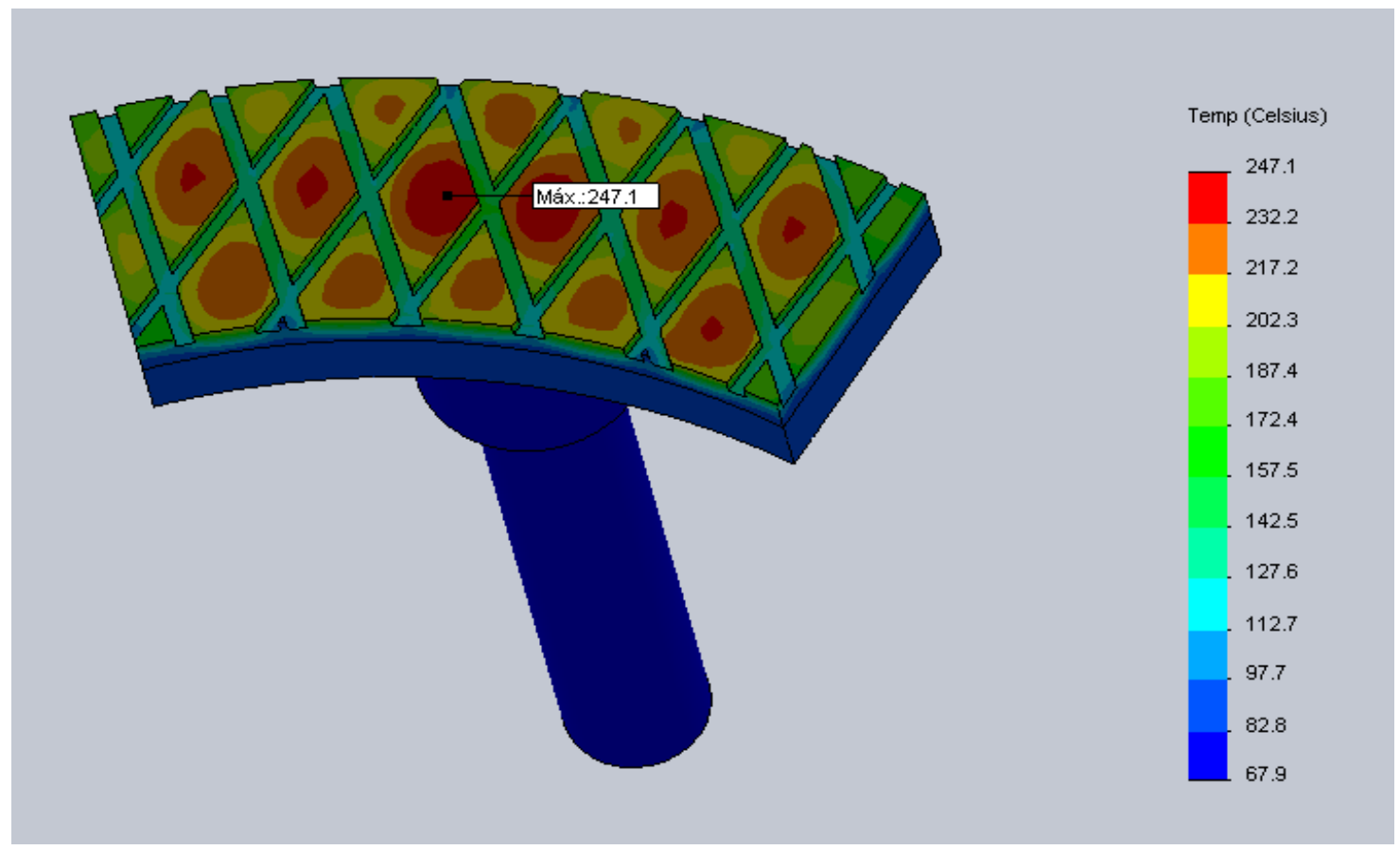

Figura 5.19: Distribuição de temperaturas para $0,8 \mathrm{kcal} / \mathrm{cm}^{2} / \mathrm{h}$, modelo com rasgos em " $X$ " 


\section{4- PRIMEIRA BATERIA DE TESTES PINO SOBRE DISCO}

Esses testes foram realizados para ajustes que se fizessem necessários à segunda fase de testes. Alguns pontos ficaram evidenciados nestes ensaios que facilitam a compreensão do processo de desgaste das lonas e comprovam algumas suposições mostradas anteriormente.

A figura 5.20 mostra a evolução do coeficiente de atrito durante um ensaio a $100 \mathrm{~N}$ e a $100 \mathrm{rpm}$. O final ensaio se deu pelo descolamento da lona de seu suporte.

Notamos até os $2100 \mathrm{~s}$ um crescimento do coeficiente de atrito, indicando um período longo de acomodação ("running in") em função da característica superficial da lona e após $1300 \mathrm{~s}$ há também adesão do polímero ao contracorpo, em função dos altos coeficientes de atrito medidos.

Observa-se em 700 s, 1500 s e 2100 s uma redução brusca do coeficiente de atrito, o que corresponde aos instantes nos quais a trilha foi limpa de resíduos e provavelmente houve uma diminuição de terceiros corpos no contato lona e contra-corpo. Isso indica que a presença de terceiros corpos no contato, que neste caso implica em um crescimento do coeficiente de atrito, Oestermayer (2003).

A partir da última limpeza da trilha aos 2100 s, após a diminuição brusca do coeficiente de atrito há uma diminuição lenta do mesmo. Pode-se associar esse fato ao aquecimento da lona. O crescimento do coeficiente de atrito pelo aumento da relação área real de contato / área aparente de contato é suplantado pela diminuição do mesmo pelo efeito térmico no polímero, reduzindo as propriedades mecânicas do polímero e da união entre abrasivo polímero. Isso vem a confirmar o que temos nas especificações de diversas lonas: coeficiente de atrito a frio e coeficiente de atrito a quente. Isso é coerente com a revisão bibliográfica que mostra a diminuição do coeficiente de atrito com o aumento da temperatura. Nas informações técnicas de fornecedores de lona é informado o coeficiente de atrito a quente, que seria o valor do coeficiente de atrito para a condição limite da temperatura de trabalho (ou valor próximo a ela). 


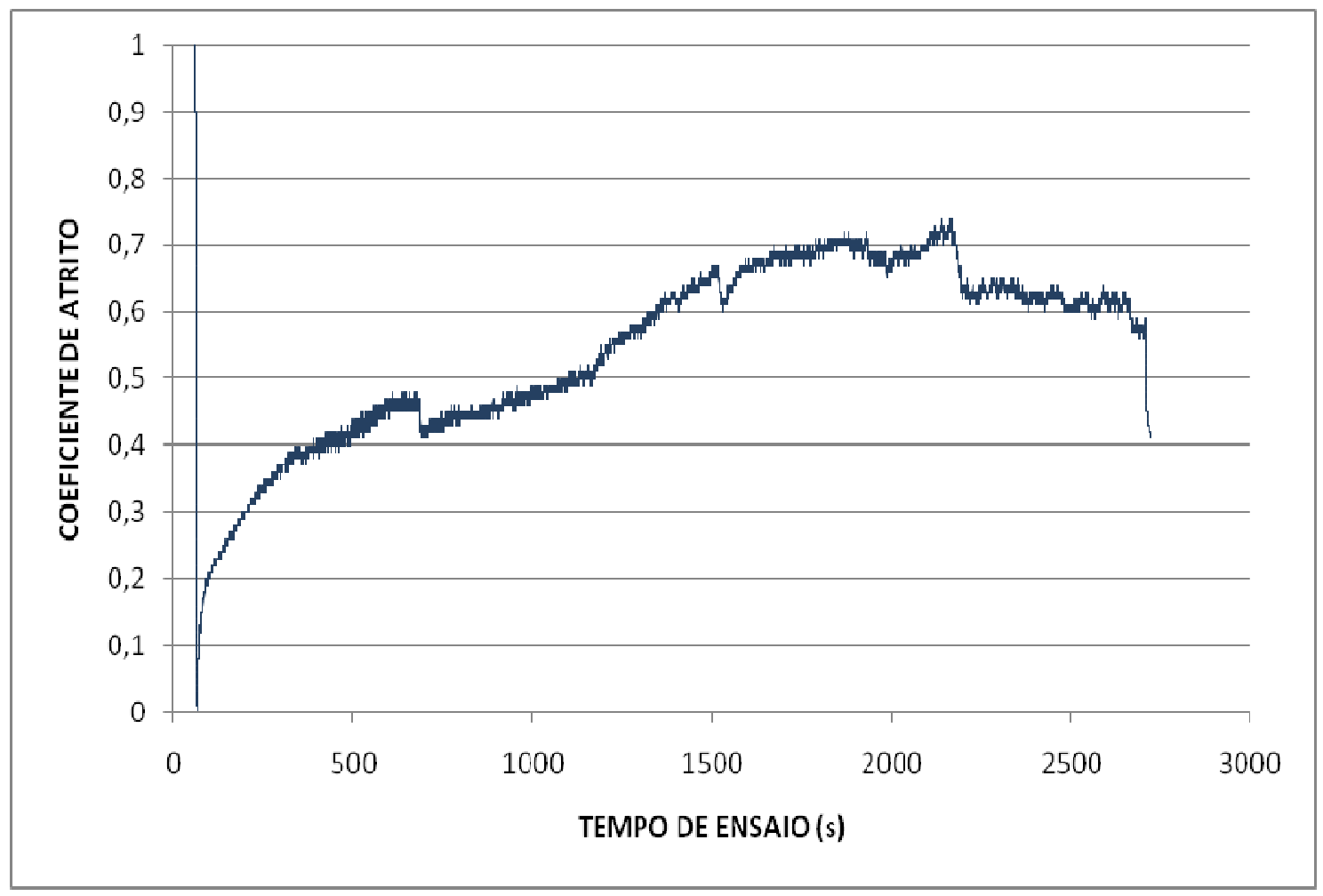

Figura 5.20: Coeficiente de atrito ensaio de $100 \mathrm{~N}$ a 100 rpm.

A figura 5.21 mostra duas séries de ensaios, na série 1 foi ensaiada uma lona nova a $200 \mathrm{~N}$ e a $100 \mathrm{rpm}$ até o descolamento do suporte. Essa mesma lona após seu resfriamento foi novamente colada ao suporte e ensaiada até seu descolamento. A série 1 mostra claramente a evolução do coeficiente de atrito durante o "running in". Não houve quedas bruscas de coeficiente de atrito como na figura 5.20, pois não se efetuou nenhuma limpeza de trilha. A série 2 mostra um "running in" bem curto, mais uma adaptação da nova colagem. A partir dos 1500 s o coeficiente de atrito começa a cair em função do aquecimento da Iona.

Todos os corpos-de-prova foram retirados de uma mesma placa e como visto em 4.1 existem grandes diferenças locais quanto ao material. Isso ocorreu nos ensaios mostrados na figura 5.22, confirmando o dito em 4.1. Esses ensaios foram realizados a $500 \mathrm{rpm}$ com carga de $100 \mathrm{~N}$.

Houve limpeza de resíduos na trilha em ambos os testes, causando uma queda abrupta e momentânea do coeficiente de atrito.

A série 1 apresentou um maior coeficiente de atrito, menor tempo de "running in". Foi utilizada uma lona já usada anteriormente, explicando tal fato. 


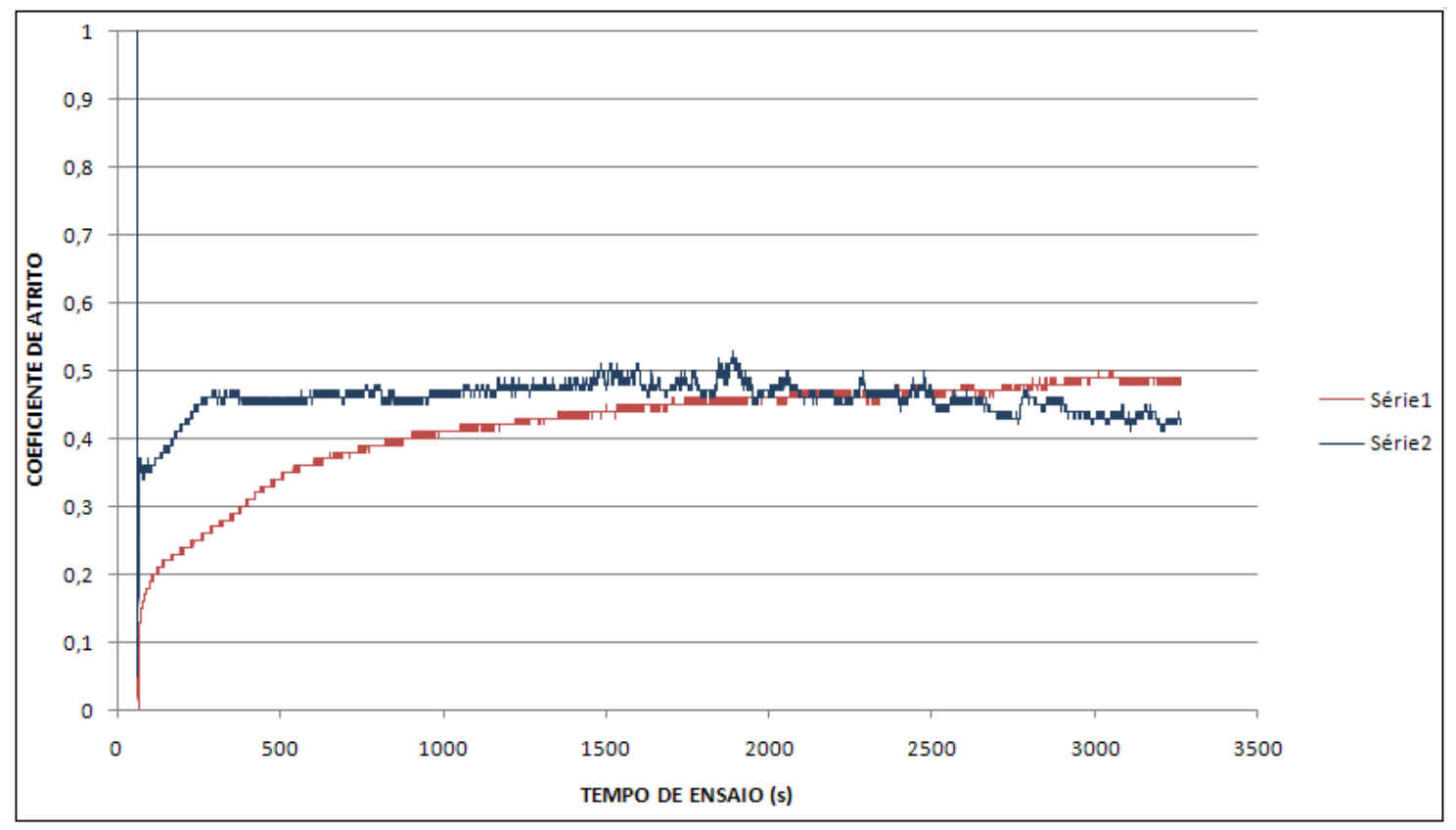

Figura 5.21: Coeficiente de atrito ensaio de $200 \mathrm{~N}$ a 100 rpm.

Há em ambas as séries, uma diferença na razão de crescimento do coeficiente de atrito durante o "running in". Essa razão de crescimento diminui com o tempo, pode-se associar esse fato a existencia de dois processos acontecendo ao mesmo tempo, um crescimento da área real de contato que implica no aumento do coeficiente de atrito, ao mesmo tempo, que com o aumento da temperatura a resistência mecânica do polímero cai, diminuindo a força de engastamento dos abrasivos, diminuindo o coeficiente de atrito.

A figura 5.23, ensaio a $200 \mathrm{~N}$ e $500 \mathrm{rpm}$ mostra a variação do coeficiente de atrito nas três amostras, confirmando o que foi dito em 4.1.

A figura 5.24 refere-se a um ensaio a $250 \mathrm{~N}$ e 500 rpm, utilizando um corpo-deprova do ensaio anterior (fig. 4.19) onde a camada degradada foi retirada por uma lixa fina e novamente colado ao suporte. Nota-se um curto "running in", seguido por uma queda do coeficiente de atrito.

A figura 5.25 mostra um ensaio com $100 \mathrm{~N}$ e 750 rpm quanto à variação do coeficiente de atrito nas três amostras, confirmando dito em 4.1.

A figura 5.26 mostra um ensaio com 100 N e 1500 rpm. Esse ensaio preliminar foi feito apenas para teste dos futuros ensaios a maior velocidade.

Essa primeira bateria de testes, inclusive com alguns testes sem repetições foi um treinamento para a segunda bateria de testes, porém alguns testes 
apresentaram resultados interessantes, mostrando alguns pontos comentados anteriormente, daí a razão de sua apresentação.

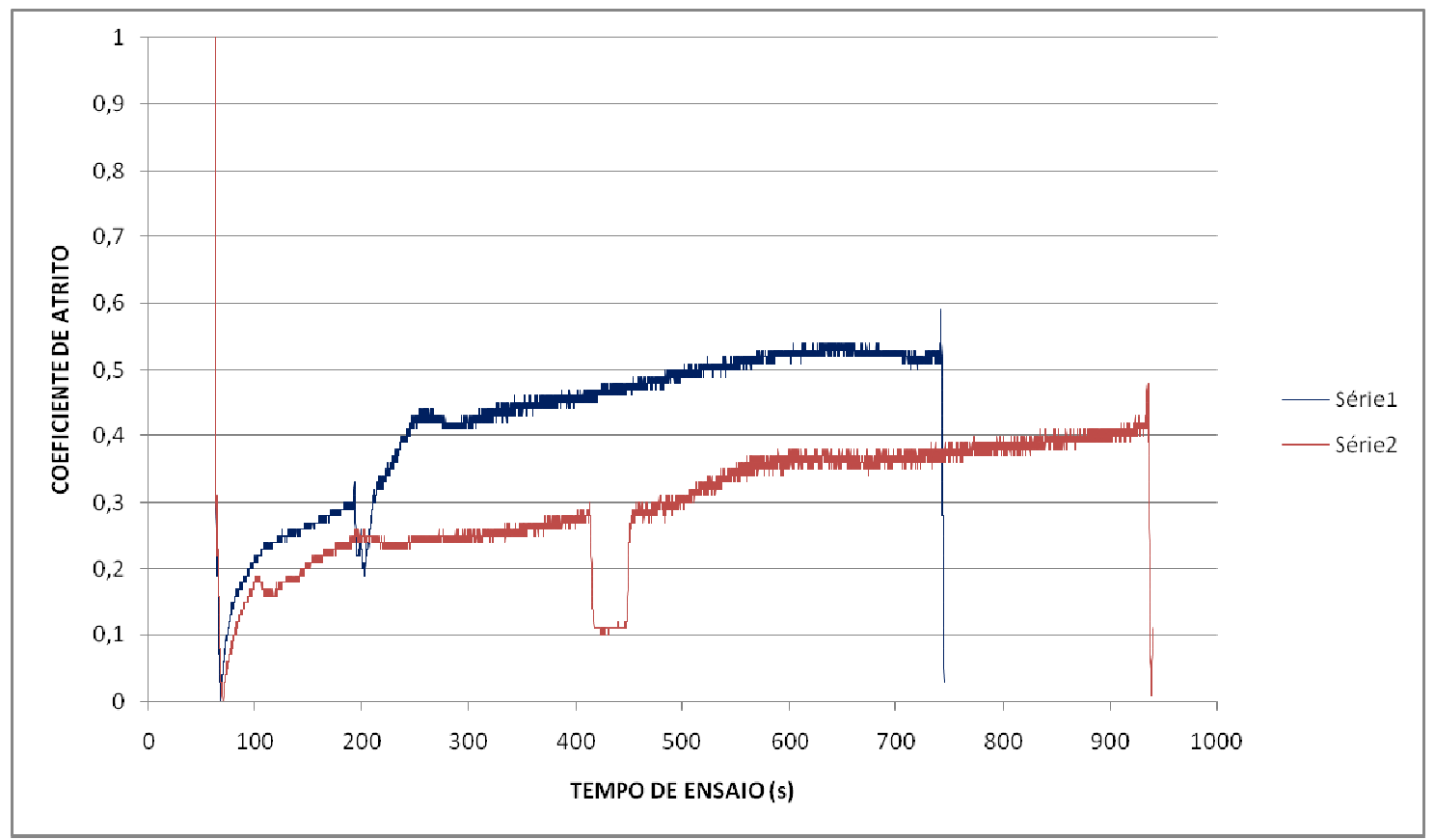

Figura 5.22: Coeficiente de atrito ensaio de $100 \mathrm{~N}$ a $500 \mathrm{rpm}$.

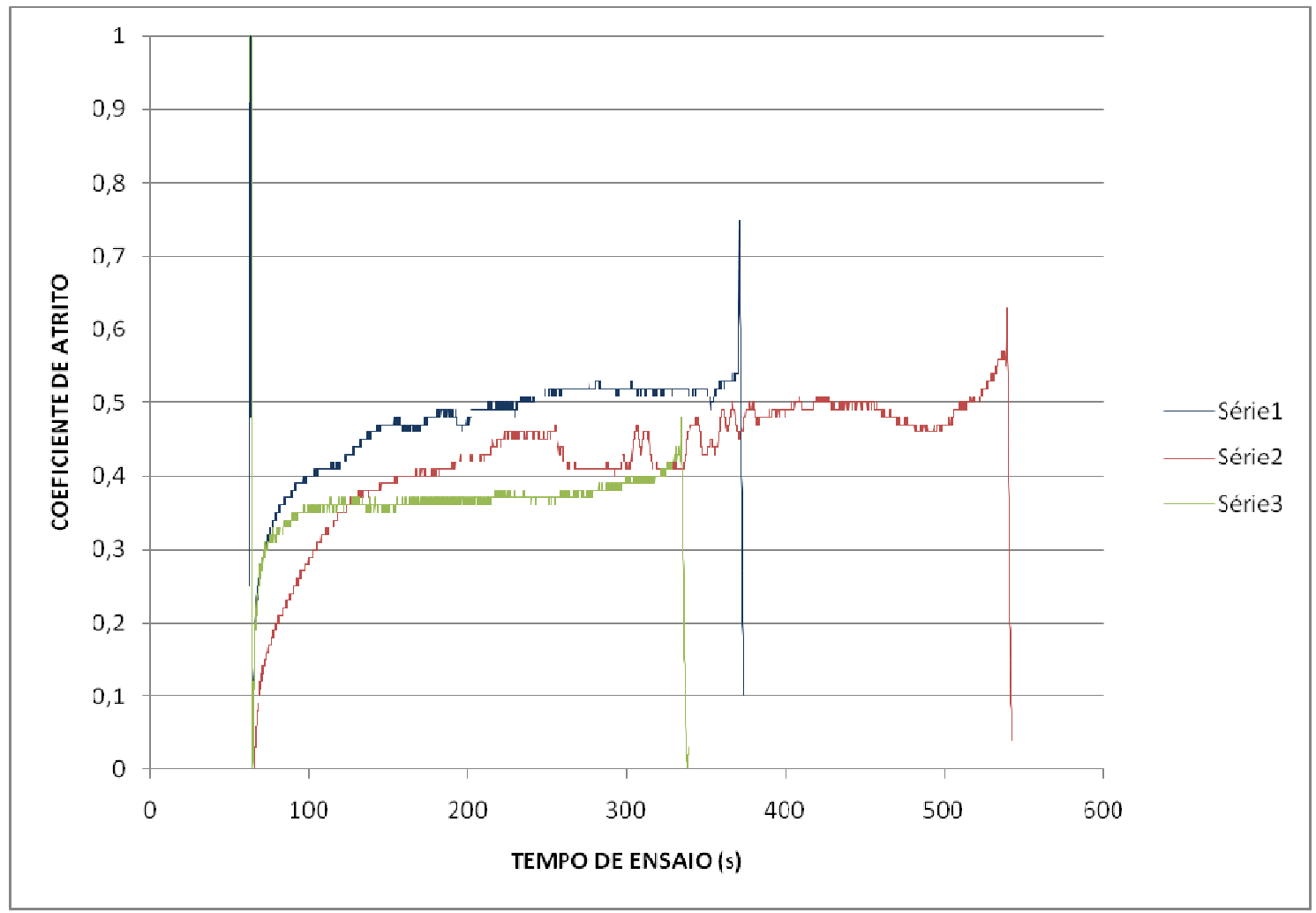

Figura 5.23: Coeficiente de atrito ensaio de $200 \mathrm{~N}$ a 500 rpm. 


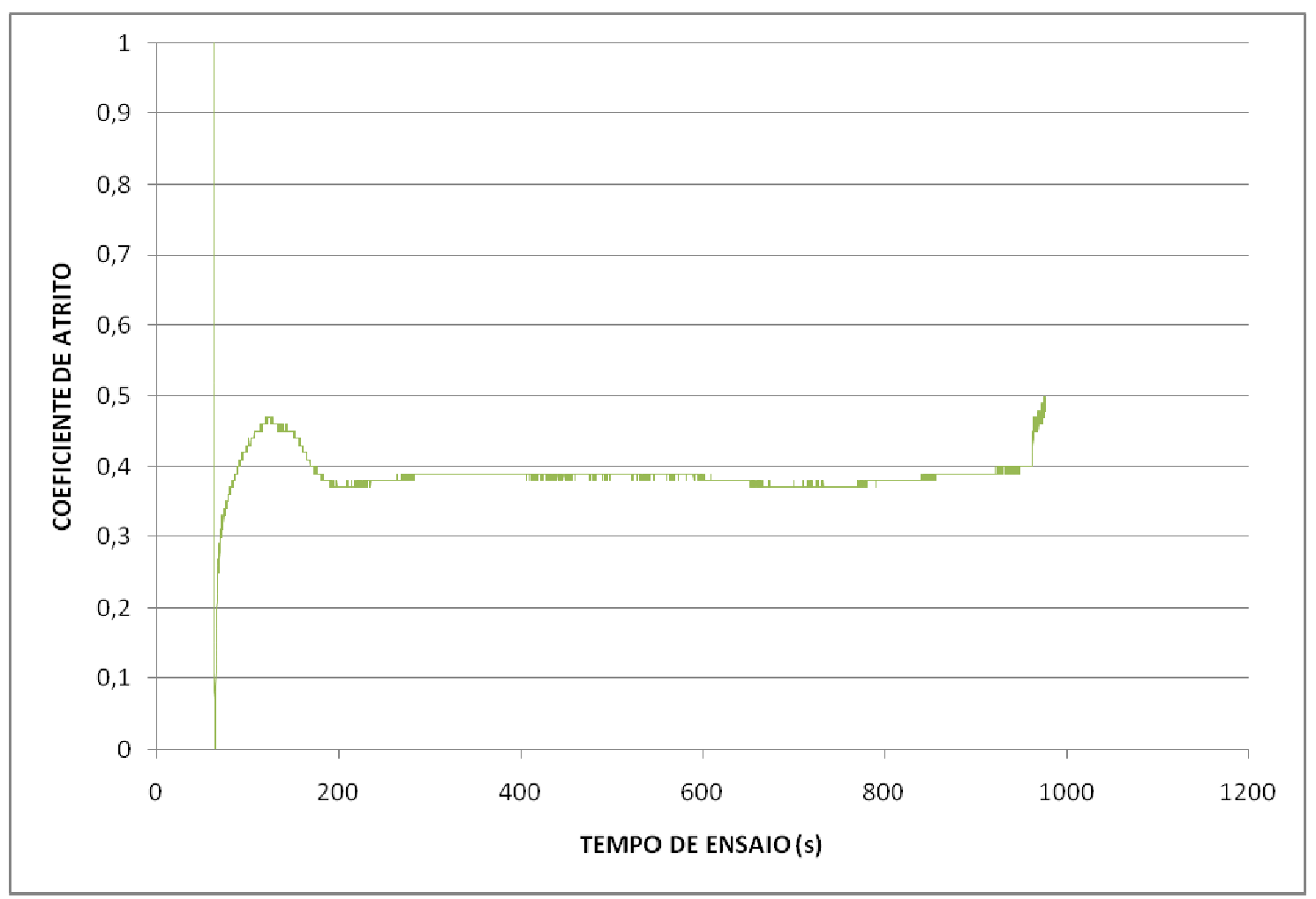

Figura 5.24: Coeficiente de atrito ensaio de $250 \mathrm{~N}$ a $500 \mathrm{rpm}$.

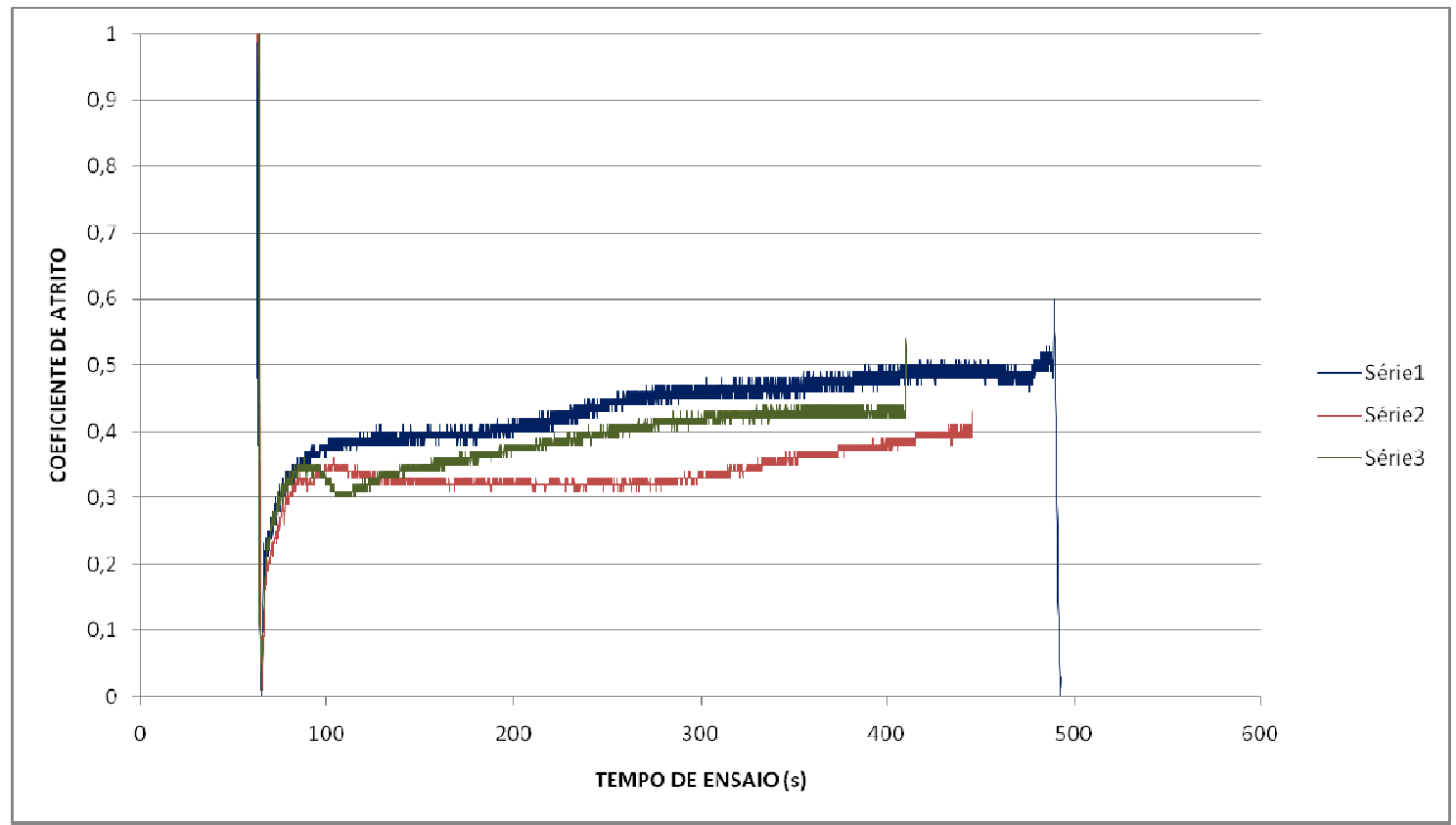

Figura 5.25: Coeficiente de atrito ensaio de $100 \mathrm{~N}$ a $750 \mathrm{rpm}$. 


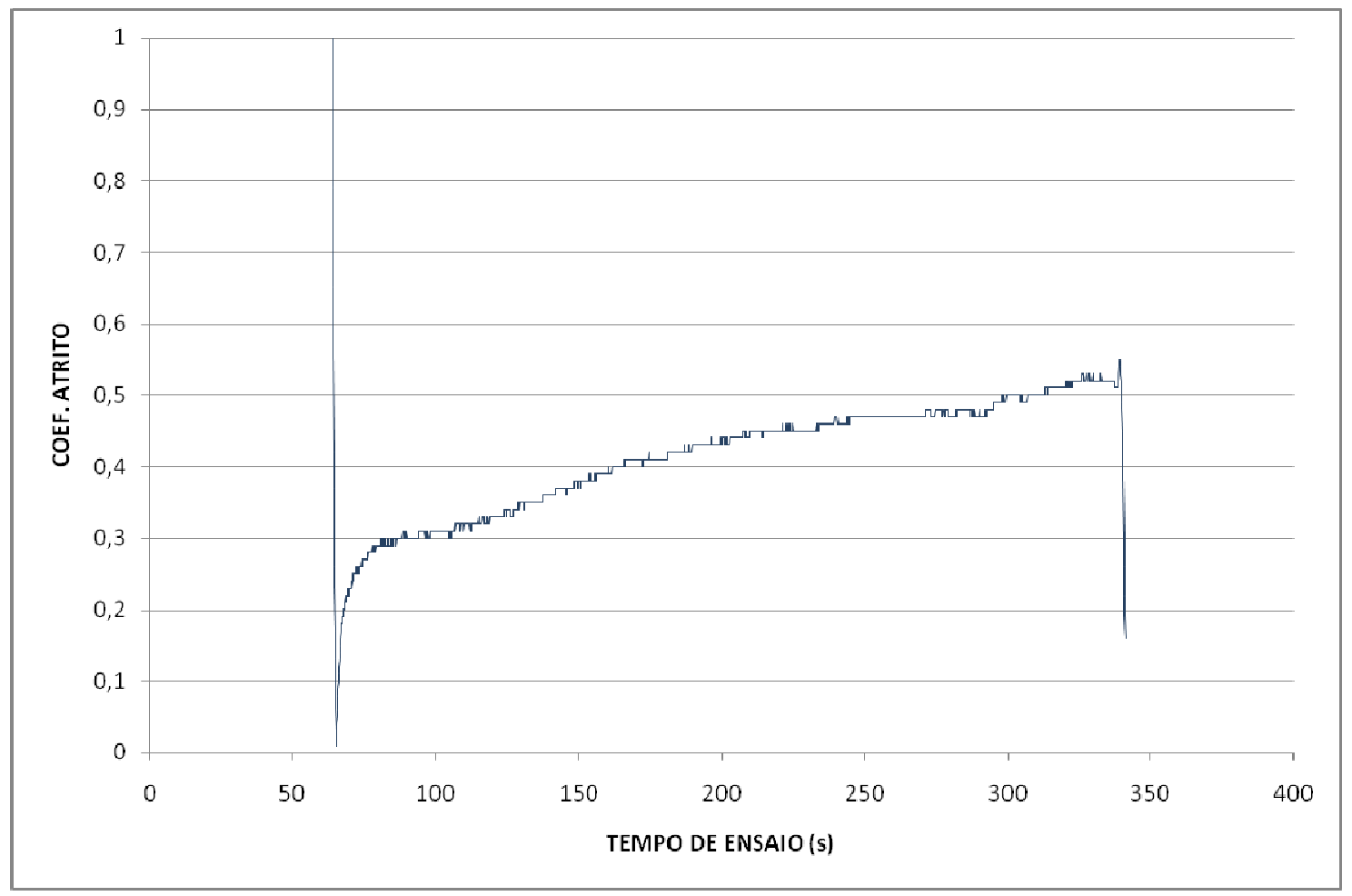

Figura 5.26: Coeficiente de atrito ensaio de $100 \mathrm{~N}$ a 1500 rpm.. 


\section{5- SEGUNDA BATERIA DE TESTES PINO SOBRE DISCO}

Os testes da segunda bateria foram executados depois que cada lona foi submetida a uma carga e rotação até a estabilização do coeficiente de atrito (tentativa de minimizar o "running in" no ensaio). Após seu resfriamento, cada lona foi pesada e após o ensaio foi novamente pesada, os resultados são apresentados na tabela 5.1.

Tabela 5.1: Perda de massa nos ensaios pino sobre disco.

\begin{tabular}{|c|c|c|c|c|c|c|c|}
\hline & VELOC. & DIAM. & TEMPO & DISTANC. & PESO 1 & PESO 2 & PERDA \\
\hline & $\mathbf{r p m}$ & $\mathbf{m m}$ & $\mathbf{( s )}$ & $\mathbf{( m )}$ & $\mathbf{~ m g}$ & $\mathbf{~ m g}$ & MASSA \\
\hline AMOSTRA 1 & 1000 & 80 & 1200 & 5026,56 & 3467,9 & 3458,6 & 9,3 \\
\hline AMOSTRA 2 & 1000 & 80 & 1200 & 5026,56 & 3443,2 & 3426,9 & 16,3 \\
\hline AMOSTRA 3 & 1000 & 80 & 800 & 3351,04 & 3527,7 & 3521,7 & 6 \\
\hline AMOSTRA 4 & 1000 & 80 & 800 & 3351,04 & 3272,6 & 3209,3 & 63,3 \\
\hline AMOSTRA 5 & 1000 & 80 & 800 & 3351,04 & 3595,6 & 3531,8 & 63,8 \\
\hline AMOSTRA 6 & 1000 & 80 & 800 & 3351,04 & 3513,1 & 3430,8 & 82,3 \\
\hline AMOSTRA 7 & 1000 & 80 & 800 & 3351,04 & 3432,8 & 3344,7 & 88,1 \\
\hline
\end{tabular}

\begin{tabular}{|l|c|c|c|c|c|c|}
\hline & PERDA & CARGA & DESGAST. & & T. DESG & \\
\hline & MÉDIA & $(\mathbf{N})$ & $\mu \mathrm{g} / \mathbf{m}$ & & $(\mu \mathrm{g} / \mathbf{m} / \mathbf{N})$ & \\
\hline AMOSTRA 1 & & 60 & 1,8502 & & 0,0308 & \\
\hline AMOSTRA 2 & & 60 & 3,2428 & & 0,0540 & \\
\hline AMOSTRA 3 & 10,53 & 60 & 1,7905 & & 0,0298 & $\mathbf{0 , 0 3 8 2}$ \\
\hline AMOSTRA 4 & & 180 & 18,8897 & & 0,1049 & \\
\hline AMOSTRA 5 & 63,55 & 180 & 19,0389 & 18,9643 & 0,1058 & $\mathbf{0 , 1 0 5 4}$ \\
\hline AMOSTRA 6 & & 240 & 24,5595 & & 0,1023 & \\
\hline AMOSTRA 7 & 85,20 & 240 & 26,2903 & 25,4249 & 0,1095 & $\mathbf{0 , 1 0 5 9}$ \\
\hline
\end{tabular}

Nota-se uma grande diferença na perda de massa nas três primeiras amostras com as restantes. Se definir o "desgaste" ser definido com base na perda de massa por distância percorrida tem-se: $2,3 \mu \mathrm{g} / \mathrm{m}$ para a carga de $60 \mathrm{~N}, 19 \mu \mathrm{g} / \mathrm{m}$ para a carga de $180 \mathrm{~N}$ e $25,4 \mu \mathrm{g} / \mathrm{m}$ para a carga de $240 \mathrm{~N}$. Calculando-se a taxa de desgaste (normalizando o desgaste em relação à carga) tem-se: 0,038 $\mu \mathrm{g} /(\mathrm{mxN})$ para a carga de $60 \mathrm{~N}, 0,1054 \mu \mathrm{g} /(\mathrm{mxN})$ para a carga de $180 \mathrm{~N} \mathrm{e}$ $0,1059 \mu \mathrm{g} /(\mathrm{mxN})$ para a carga de $240 \mathrm{~N}$. Isso mostra que o regime de desgaste para baixas cargas é menos severo que para cargas mais altas. Esse fato está associado à temperatura que as lonas estão operando e ainda mais, essa diferença de mais de três vezes não pode ser explicada apenas pela redução das propriedades mecânicas do polímero base, mas sim pela sua degradação. 
As cores dos contra-corpos após os ensaios mostram claramente o nível das temperaturas atingido nos ensaios. Nos ensaios com baixa carga não houve mudança significativa da cor do contra corpo e nos outros com carga alta apresentou a cor amarelo palha no geral e os tons azulados na pista, indicando que se atingiu temperaturas acima da temperatura de degradação da base polimérica, como mostram as figuras 5.27 e 5.28 .

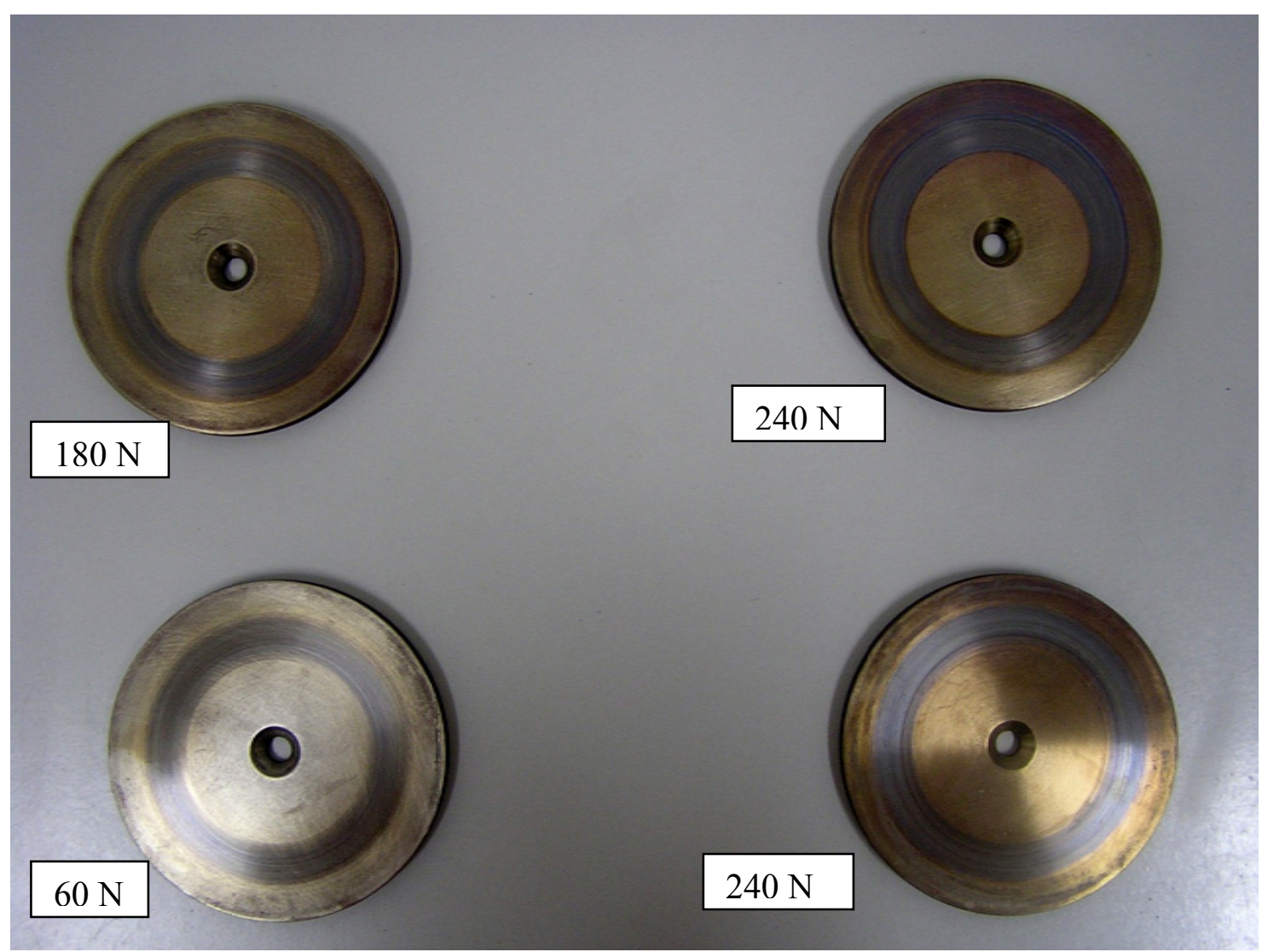

Figura 5.27 - Contra corpos após ensaios pino sobre disco

As curvas do coeficiente de atrito obtidas nos ensaios são mostradas nas figuras $5.29,5.30$ e 5.31 .

A figura 5.29 mostra que os valores de coeficiente de atrito se mantêm dentro dos valores nominais de catálogo. Existe um pequeno "running in" na curva vermelha, na curva azul e na vermelha. No final do ensaio temos um aumento do coeficiente de atrito provavelmente por grudamento ("sticking").

A figura 5.30 mostra um "running in", posteriormente uma queda no coeficiente de atrito (coeficiente de atrito a quente). 
A figura 5.31 mostra algo importante, após uma queda no coeficiente de atrito (coeficiente de atrito a quente) existe uma segunda queda abrupta do mesmo. A primeira queda pode ser explicada pelo aumento da temperatura e redução das propriedades mecânicas do polímero base influenciando no engastamento dos abrasivos. A segunda queda pode ser explicada por a lona estar se degradando aceleradamente e a quantidade de grafite aumentar muito. $O$ crescimento do coeficiente de atrito no final do ensaio pode ter alguma relação com filmes formados pelas altas temperaturas, mas o mais provável é que com a degradação da base polimérica e a alta temperatura da parte não degradada ainda exista um acúmulo de abrasivos na interface aumentando o coeficiente de atrito. Em 5.7 discute-se mais essa figura.

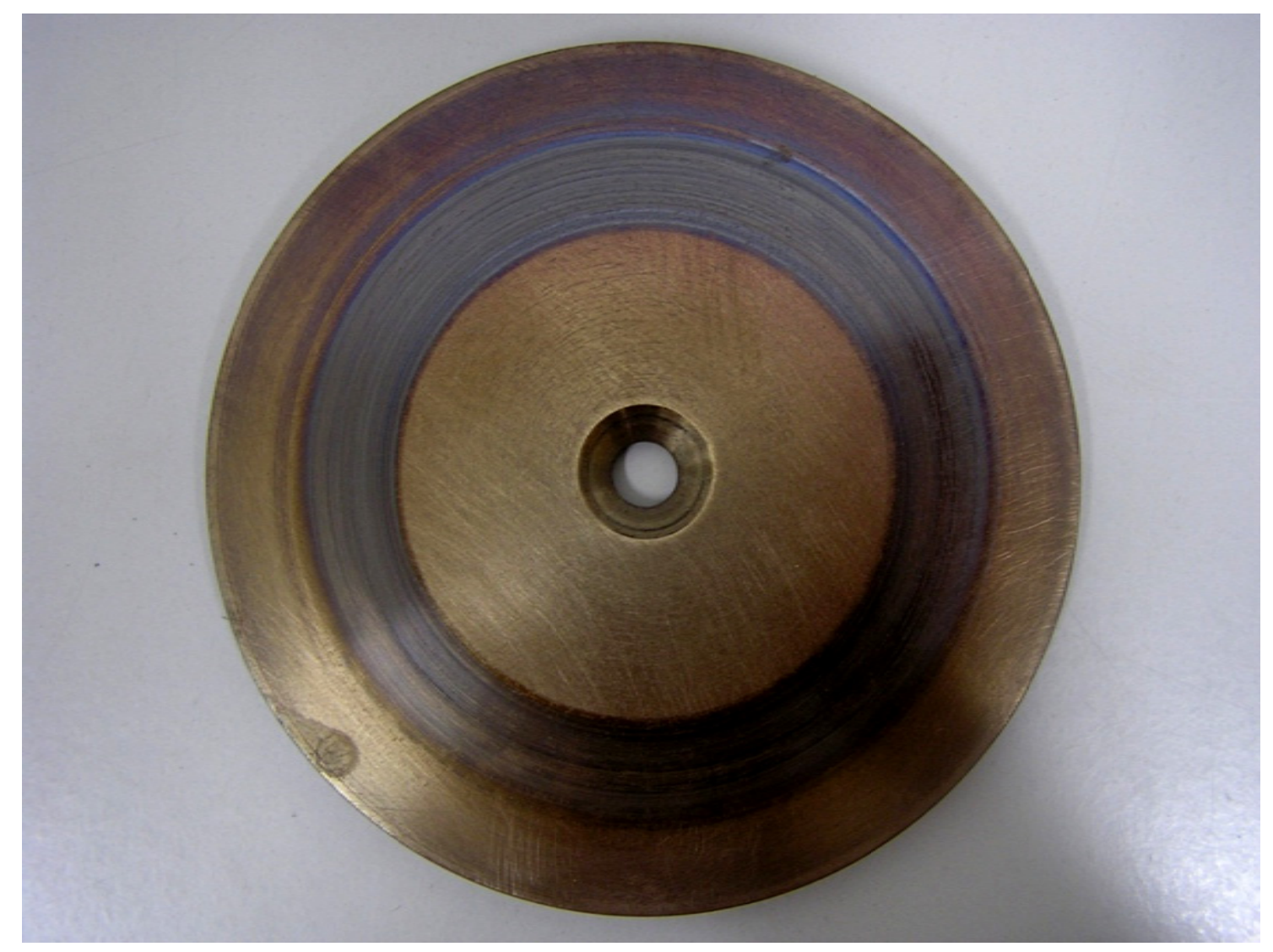

Figura 5.28 - Contra corpo após ensaio pino sobre disco com 240 N 


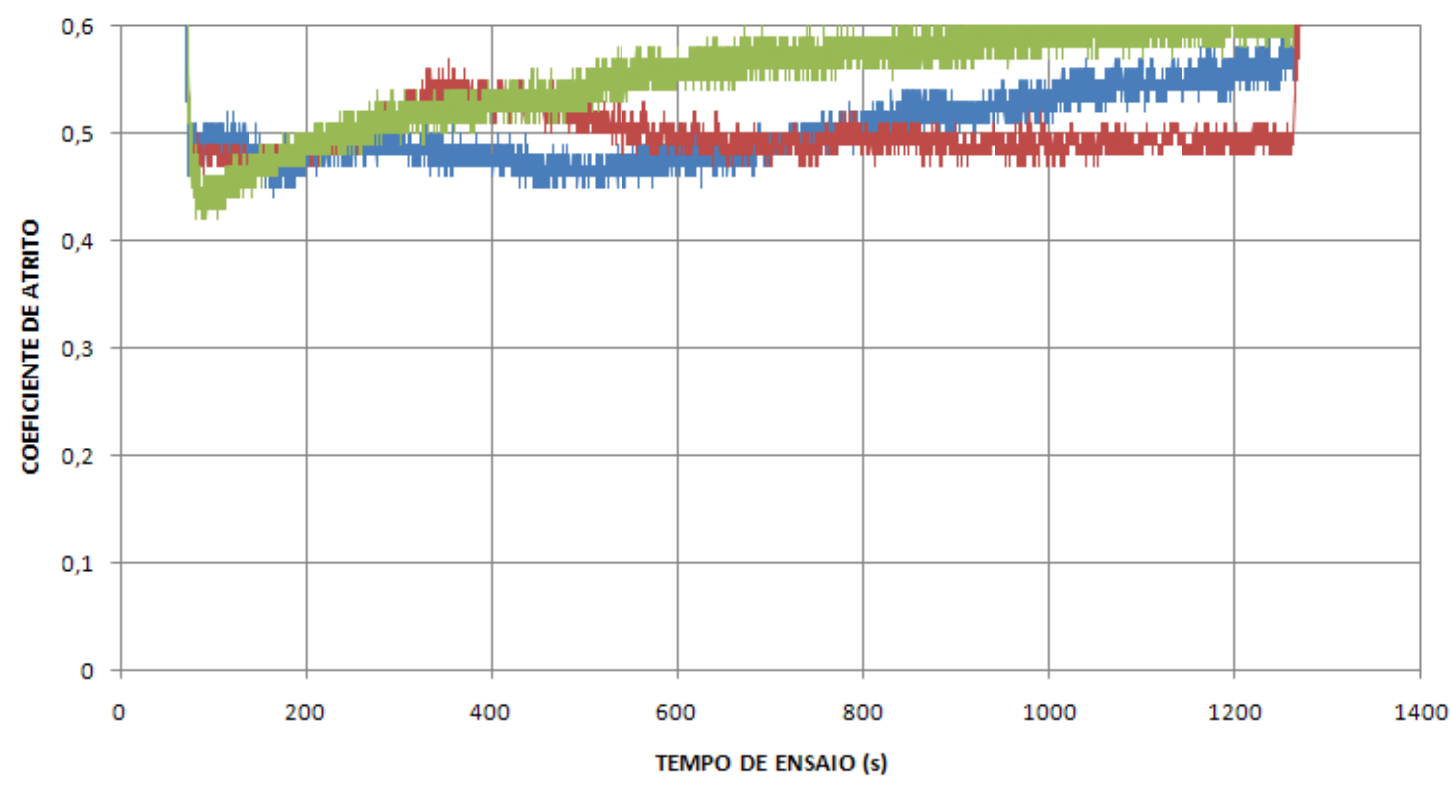

Figura 5.29: Coeficiente de atrito no ensaio com carga de $60 \mathrm{~N}$.

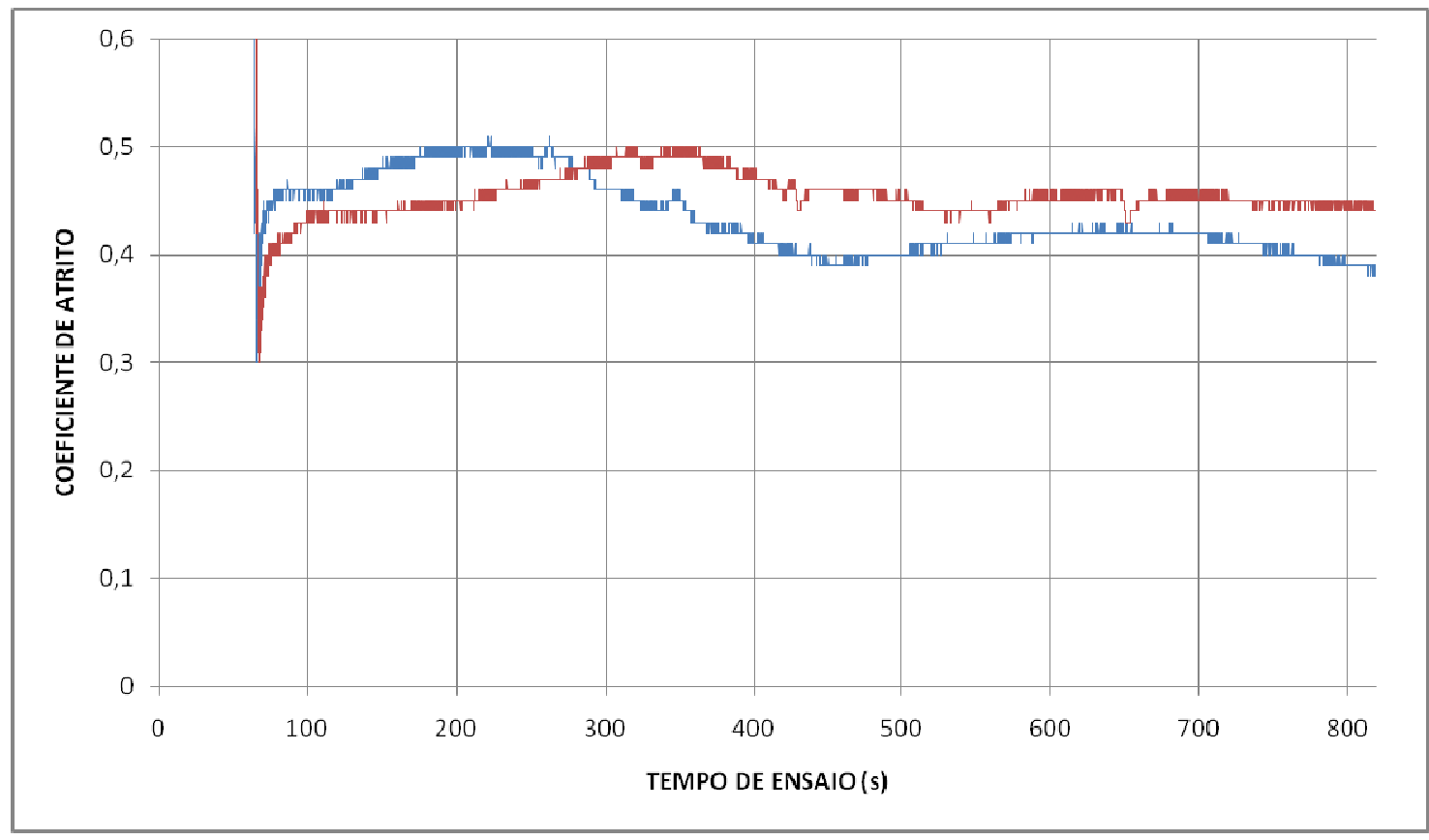

Figura 5.30: Coeficiente de atrito no ensaio com carga de $180 \mathrm{~N}$. 


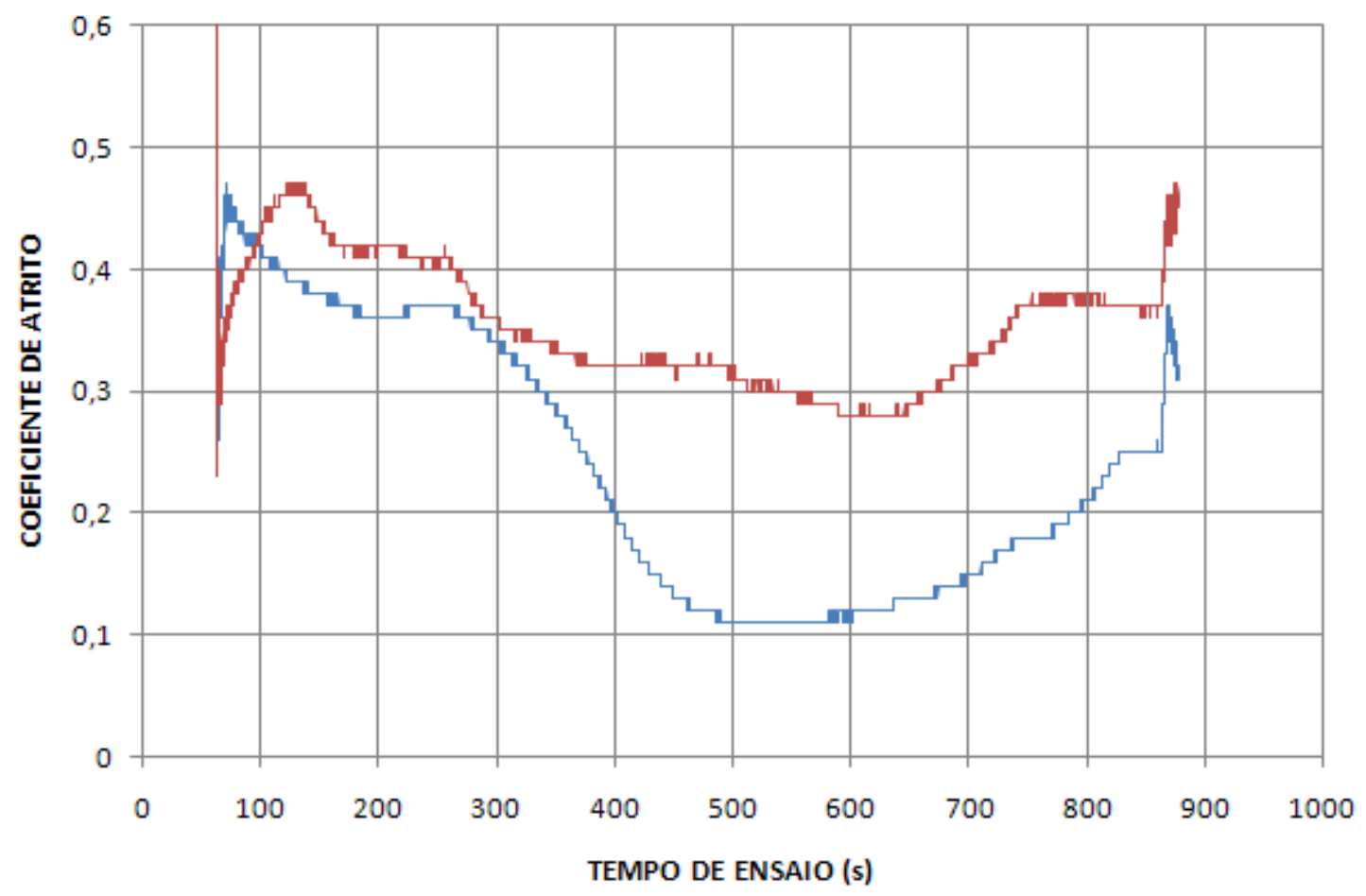

Figura 5.31: Coeficiente de atrito no ensaio com carga de $240 \mathrm{~N}$. 


\section{5-6 ESTIMATIVA DAS TEMPERATURAS NA FACE}

A temperatura da face dos corpos de prova durante o ensaio é um desafio quanto à utilização de termopares. Foram feitos testes com termopares no suporte do corpo de prova e as medidas não foram significativas. Em virtude da limitação de recursos foi utilizada uma alternativa mais econômica, que a obtenção das temperaturas da face de contato por medida direta, obtenção dos valores por meio de simulação numérica. Valores reais de coeficiente de película para a convecção é algo discutível, nas simulações executadas usouse os mesmos valores empregados no projeto da UC 1000 e da UC 1600, que mostraram estar bem próximos da realidade.

As simulações foram feitas conforme as condições de ensaio, tabela 5.2.

Tabela 5.2: Condições usadas nas simulações

\begin{tabular}{|c|c|c|c|c|c|c|c|c|c|c|}
\hline area lona & 618 & $\mathrm{~mm}^{2}$ & & & & & & & & \\
\hline pressão & força & força norm & raio & perímetro & $\begin{array}{l}\text { energia } \\
\text { por volta }\end{array}$ & rotação & $\begin{array}{l}\text { tempo } \\
\text { volta }\end{array}$ & potencia & $\begin{array}{c}\text { densidade } \\
\text { potencia }\end{array}$ & \\
\hline & $\mathrm{N}$ & $\mathrm{N}$ & $\mathrm{m}$ & $\mathrm{m}$ & $\mathrm{J}$ & rpm & $\mathrm{s}$ & W & $\mathrm{W} / \mathrm{cm}^{2}$ & $\mathrm{~kW} / \mathrm{m}^{2}$ \\
\hline 99 & 60 & 24 & 0,04 & 0,126 & 3,016 & 1000 & 0,06 & 50,27 & 8,13 & 81,3 \\
\hline 165 & 100 & 40 & 0,04 & 0,126 & 5,027 & 1000 & 0,06 & 83,78 & 13,55 & 135,5 \\
\hline 198 & 120 & 48 & 0,04 & 0,126 & 6,032 & 1000 & 0,06 & 100,53 & 16,25 & 162,5 \\
\hline 297 & 180 & 72 & 0,04 & 0,126 & 9,048 & 1000 & 0,06 & 150,80 & 24,38 & 243,8 \\
\hline 396 & 240 & 96 & 0,04 & 0,126 & 12,064 & 1000 & 0,06 & 201,06 & 32,51 & 325,1 \\
\hline
\end{tabular}

Os resultados das simulações são apresentados nas figuras 5.32 a 5.36.

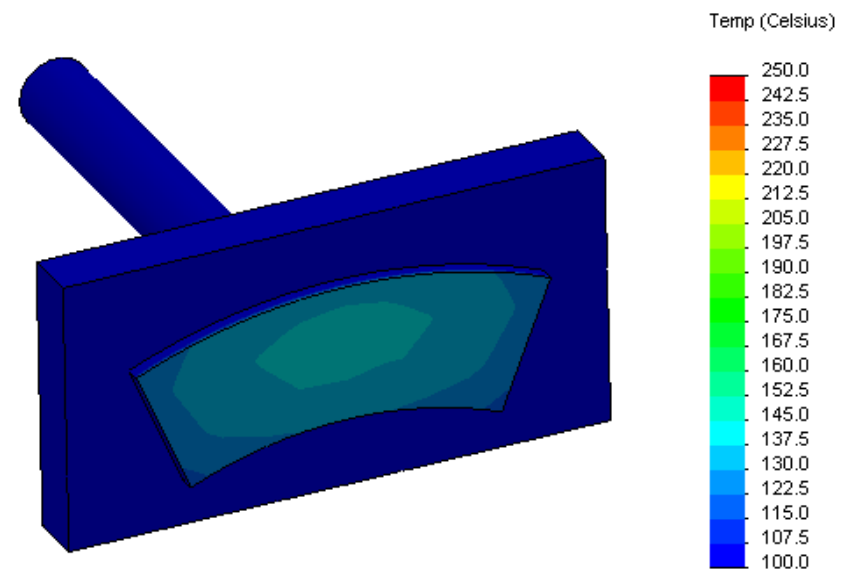

Figura 5.32: Temperaturas com carga de $60 \mathrm{~N}$. 


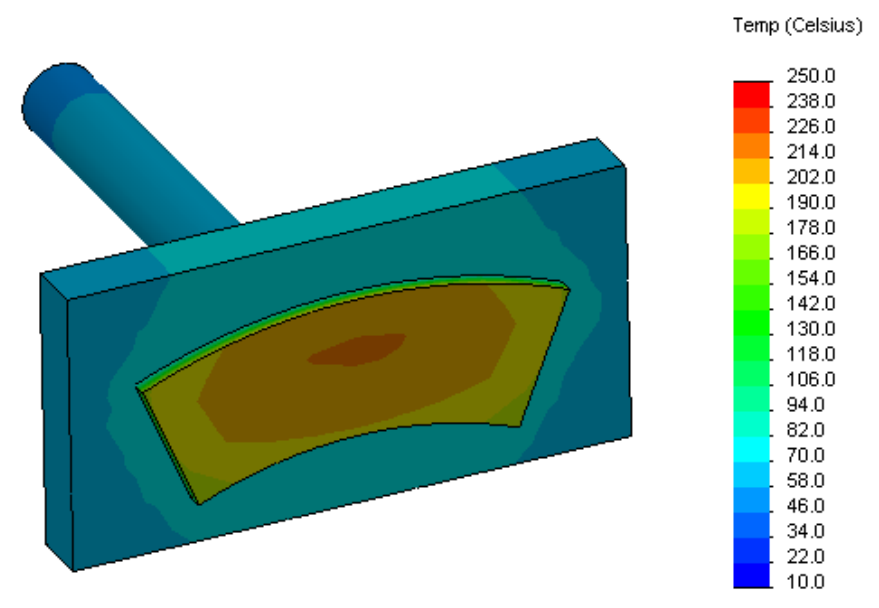

Figura 5.33: Temperaturas com carga de 100N.

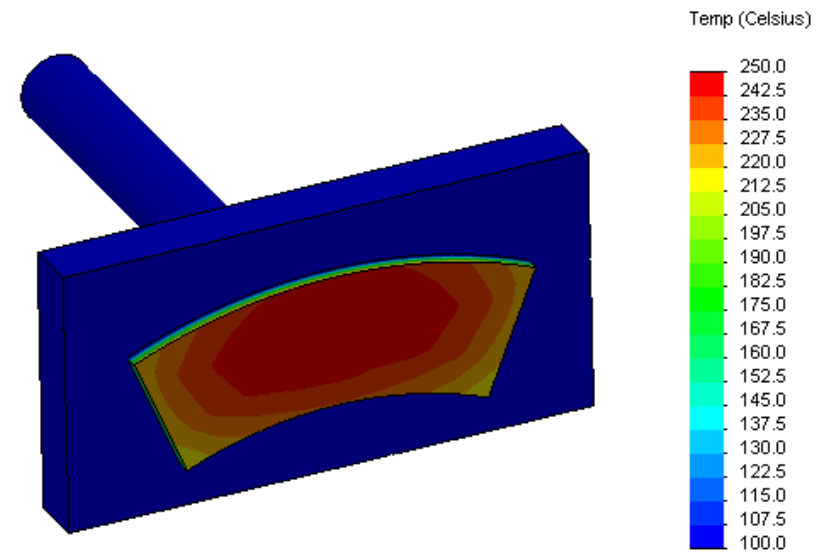

Figura 5.34: Temperaturas com carga de $120 \mathrm{~N}$.

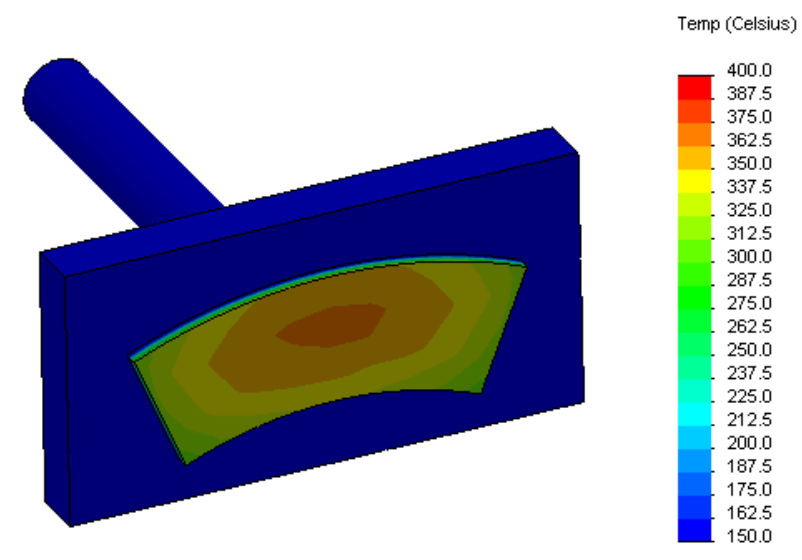

Figura 5.35: Temperaturas com carga de 180N. 


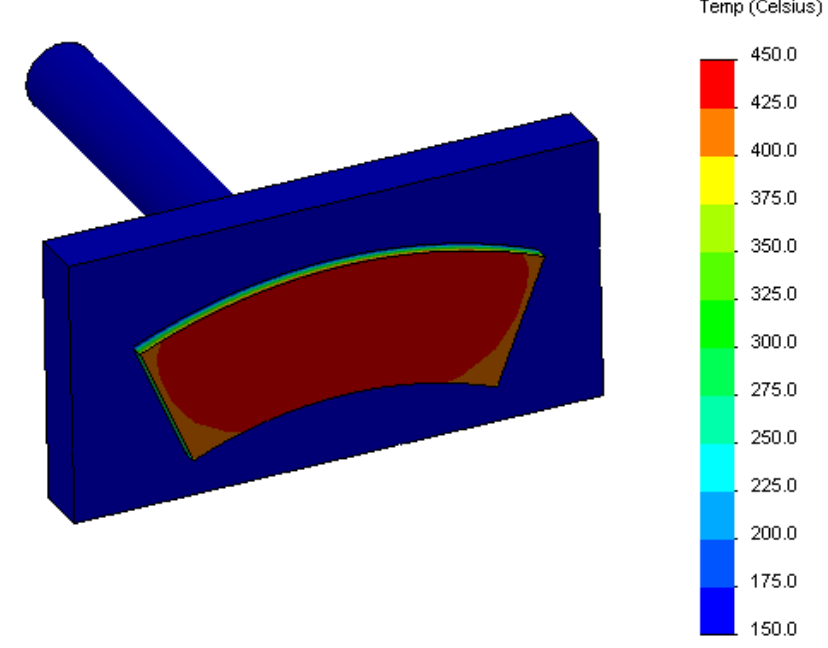

Figura 5.36: Temperaturas com carga de $240 \mathrm{~N}$.

A dificuldade da medição da temperatura na interface pode ser compreendida pelo corte da figura 5.34, onde se vê a fina camada aquecida e gradiente de temperaturas, fig. 5.37 .
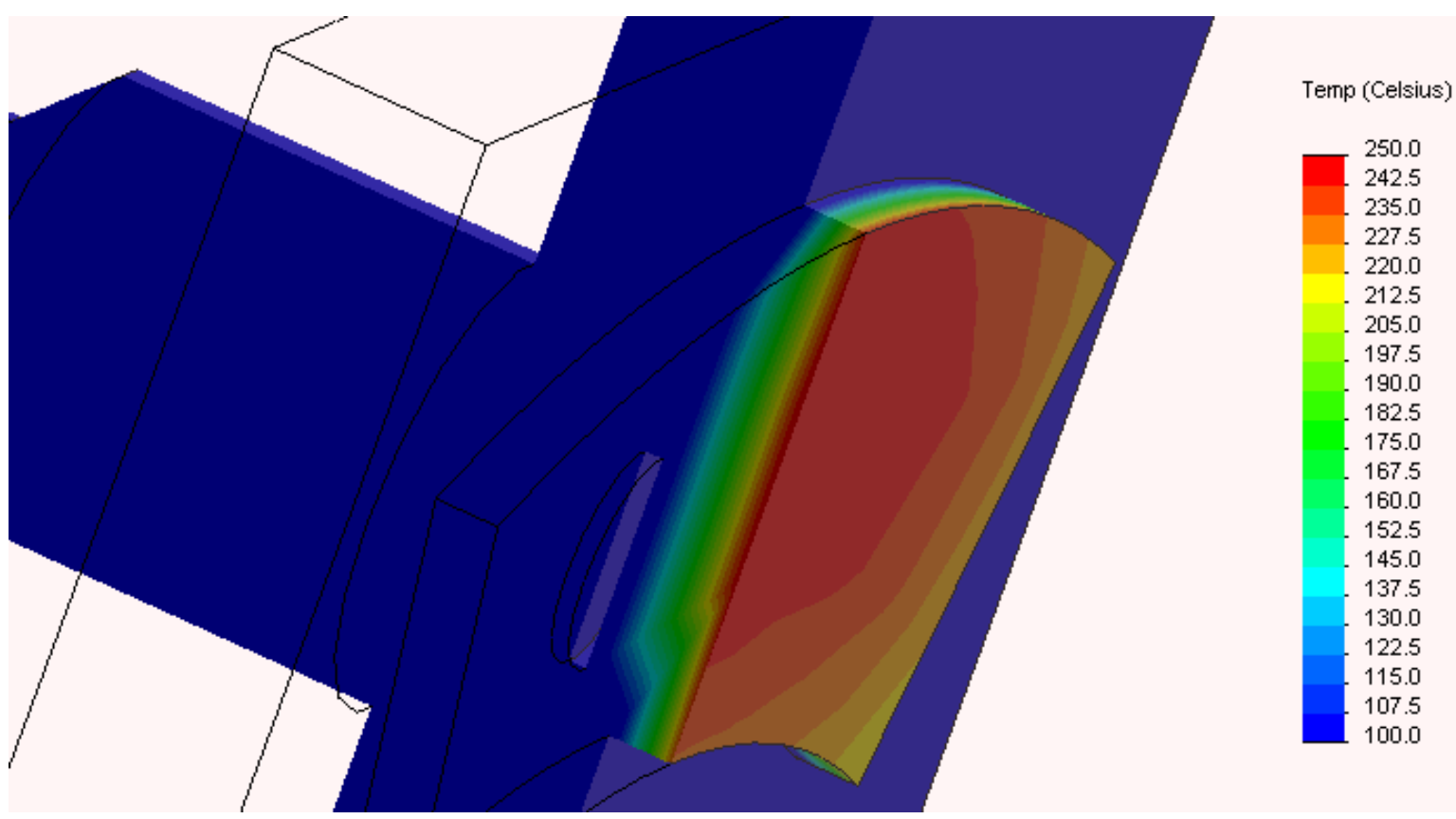

Figura 5.37: Corte da figura 5.34

A figura 5.38 mostra as temperaturas em função da pressão de contato e a figura 5.39 mostra as temperaturas em função do fluxo de calor (potência térmica por área). 


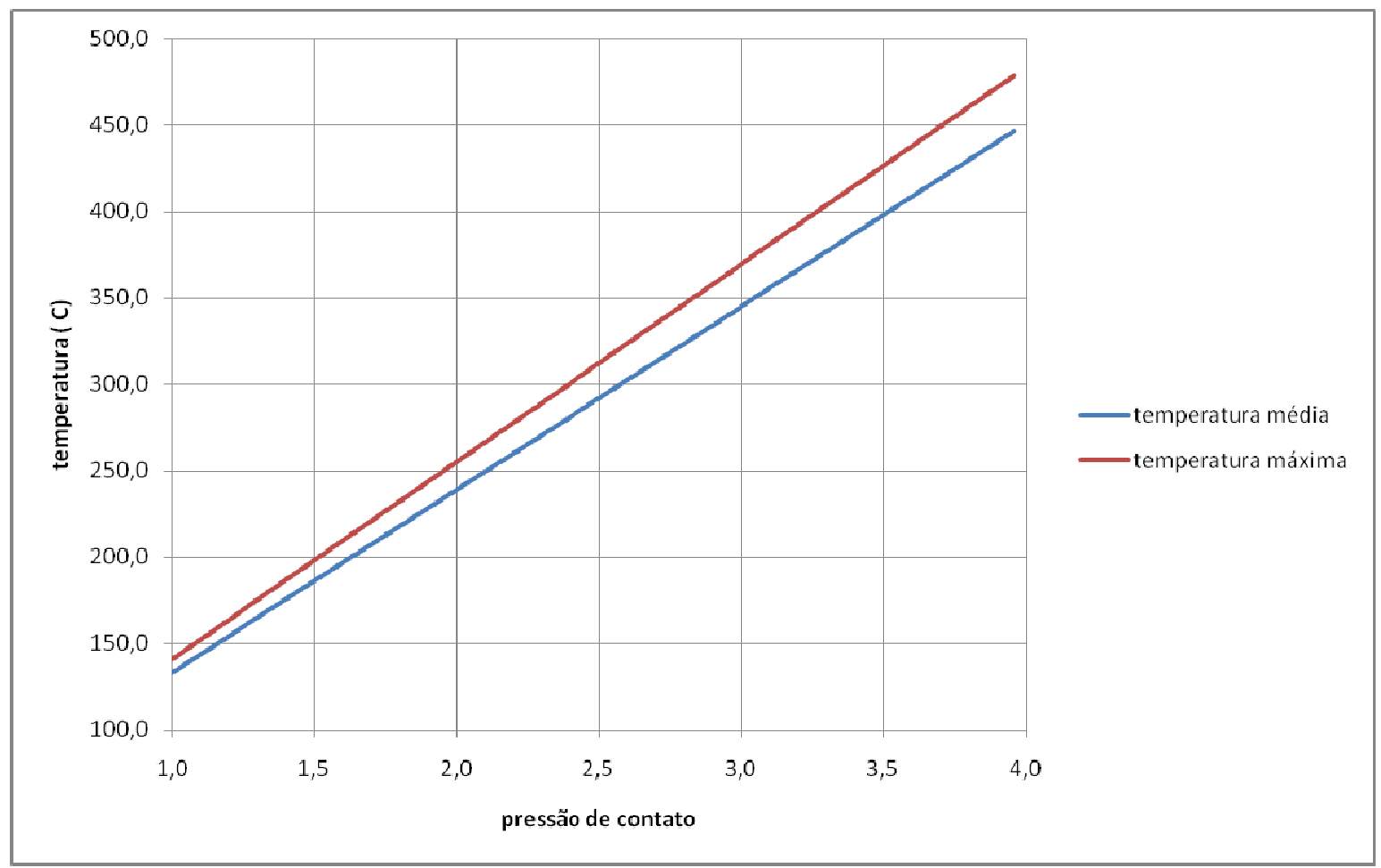

Figura 5.38: temperatura $\mathrm{x}$ pressão de contato

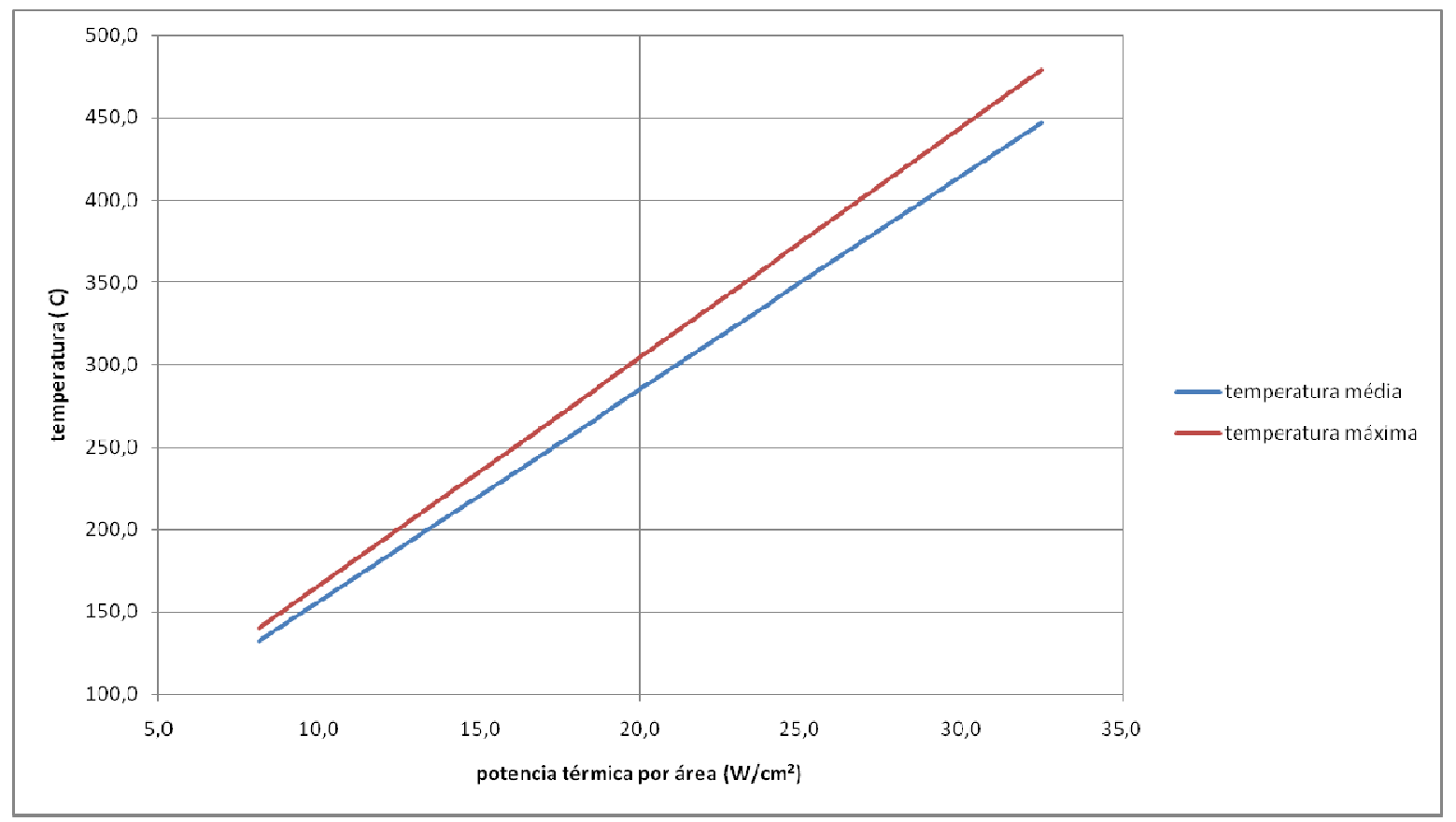

Figura 5.39: temperatura x potencia térmica por área. 


\section{7- AVALIAÇÃO DOS COEFICIENTES DE ATRITO OBTIDOS NOS ENSAIOS}

Os resultados obtidos em ensaios apresentam-se satisfatórios, correspondendo aos dados do fabricante, quanto aos valores de coeficiente de atrito a frio como se pode ver na tabela 5.3, coincidindo com os valores fornecidos pelo fabricante $(\mu=0,44)$. O mesmo ocorre com o coeficiente de atrito a quente como se pode ver na tabela 5.4, coincidindo com os valores fornecidos pelo fabricante $(\mu=0,40)$.

Outro ponto a ser ressaltado é a influência de terceiros corpos no processo, como Ostermeyer (2003) explica. Para baixas velocidades e baixas cargas aparece outro fenômeno, que se supõe ser o agarramento ("sticking") da lona ao contra corpo. Esses fenômenos implicam em aumentos do coeficiente de atrito medido nos ensaios e são apresentados na tabela 5.6, onde:

a- Amarelo e preto - provável aumento do coeficiente por terceiro corpo

b- Vermelho - agarramento ("sticking"), só ocorre a baixas cargas e baixas velocidades

c- Amarelo e vermelho - idem a "a" mas talvez com um pouco de agarramento

A embreagem citada na introdução apesar de seu desgaste acentuado não apresentava diminuição de seu torque nominal ao operar nessas condições. Têm se a idéia generalizada que nos casos de desgaste acentuado a embreagem deveria "patinar", o que não é verdade. No início do desgaste acentuado o coeficiente de atrito se mantém nos valores de atrito a quente, ao se aumentar ainda mais o regime de desgaste ele começa a diminuir.

Nos ensaios a $180 \mathrm{~N}$ e a $240 \mathrm{~N}$, a 1000 RPM, temos temperaturas superficiais altas, conforme fig. 5.35 e 5.36 . Pelas altas temperaturas superficiais sabemos que temos uma elevada perda de massa por degradação da base polimérica, fig. 5.1. A redução da eficiência da embreagem dentro do regime severo de desgaste (isto é altas pressões de contato) se dá pela queda do coeficiente de atrito. No ensaio de $180 \mathrm{~N}$ o coeficiente de atrito se mantém constante, porém no ensaio de $240 \mathrm{~N}$ após um determinado tempo há uma queda abrupta do coeficiente de atrito, fig. 5.40. Essa redução do coeficiente de atrito reduz o 
torque de embreamento ou frenagem. A razão da queda do coeficiente de atrito no regime severo de desgaste deve estar relacionada com a diminuição das propriedades mecânicas da base polimérica em razão do aumento da profundidade do aquecimento da base polimérica, caracterizando um atenuamento ("fade").

Tabela 5.3: Coeficientes de atrito a frio obtidos nos ensaios

\begin{tabular}{|c|c|c|c|c|c|c|}
\hline & $100 \mathrm{rpm}$ & $500 \mathrm{rpm}$ & 750 rpm & $1000 \mathrm{rpm}$ & $1500 \mathrm{rpm}$ & média força \\
\hline \multirow[t]{3}{*}{$60 \mathrm{~N}$} & $\mathrm{x}$ & $\mathrm{x}$ & $\mathrm{x}$ & 0,49 & $\mathrm{x}$ & 0,48 \\
\hline & $x$ & $x$ & $x$ & 0,47 & $x$ & \\
\hline & $x$ & $x$ & $x$ & 0,47 & $x$ & \\
\hline \multirow[t]{2}{*}{$100 \mathrm{~N}$} & 0,45 & 0,45 & 0,4 & $x$ & 0,47 & 0,44 \\
\hline & $x$ & 0,42 & 0,42 & $x$ & $x$ & \\
\hline \multirow[t]{2}{*}{$180 \mathrm{~N}$} & $x$ & $x$ & $x$ & 0,5 & $x$ & 0,50 \\
\hline & $x$ & $x$ & $x$ & 0,5 & $x$ & \\
\hline \multirow[t]{3}{*}{$200 \mathrm{~N}$} & 0,47 & 0,47 & 0,45 & $x$ & $x$ & 0,46 \\
\hline & 0,45 & 0,46 & $x$ & $x$ & $x$ & \\
\hline & $x$ & 0,43 & $x$ & $x$ & $x$ & \\
\hline \multirow[t]{2}{*}{$240 \mathrm{~N}$} & $x$ & $x$ & $x$ & 0,47 & $x$ & 0,48 \\
\hline & $x$ & $x$ & $x$ & 0,48 & $x$ & \\
\hline $250 \mathrm{~N}$ & $x$ & 0,47 & $x$ & $x$ & $x$ & 0,47 \\
\hline média rpm & 0,46 & 0,45 & 0,42 & 0,48 & 0,47 & 0,46 \\
\hline
\end{tabular}

Tabela 5.4: Coeficientes de atrito a quente obtidos nos ensaios.

\begin{tabular}{|l|c|c|c|c|c|c|}
\hline & $\mathbf{1 0 0} \mathbf{~ r p m}$ & $\mathbf{5 0 0} \mathbf{~ r p m}$ & $\mathbf{7 5 0} \mathbf{~ r p m}$ & $\mathbf{1 0 0 0} \mathbf{~ r p m}$ & $\mathbf{1 5 0 0} \mathbf{~ r p m}$ & \\
\hline $\mathbf{6 0} \mathbf{N}$ & & & & 0,45 & & 0,43 \\
\hline & & & & 0,42 & & \\
\hline & & & & NA & & \\
\hline $\mathbf{1 0 0} \mathbf{N}$ & NA & NA & 0,4 & & NA & 0,40 \\
\hline & & NA & NA & & & \\
\hline $\mathbf{1 8 0} \mathbf{~ N}$ & & & & 0,45 & & 0,44 \\
\hline & & & & 0,42 & & \\
\hline $\mathbf{2 0 0} \mathbf{N}$ & 0,42 & NA & 0,42 & & & 0,42 \\
\hline & NA & 0,42 & & & & \\
\hline & & NA & & & & \\
\hline $\mathbf{2 4 0} \mathbf{N}$ & & & & 0,42 & & 0,40 \\
\hline & & & & 0,38 & & \\
\hline $\mathbf{2 5 0} \mathbf{N}$ & & 0,4 & & & & 0,40 \\
\hline & $\mathbf{0 , 4 2}$ & $\mathbf{0 , 4 1}$ & $\mathbf{0 , 4 1}$ & $\mathbf{0 , 4 2}$ & & $\mathbf{0 , 4 2}$ \\
\hline
\end{tabular}


Tabela 5.5: Coeficientes de atrito acima do esperado.

\begin{tabular}{|c|c|c|c|c|c|}
\hline & $100 \mathrm{rpm}$ & $500 \mathrm{rpm}$ & $750 \mathrm{rpm}$ & $1000 \mathrm{rpm}$ & $1500 \mathrm{rpm}$ \\
\hline $60 \mathrm{~N}$ & & & & 0,57 & \\
\hline & & & & 0,6 & \\
\hline & & & & 0,57 & \\
\hline $100 \mathrm{~N}$ & 0,7 & 0,52 & 0,52 & & 0,52 \\
\hline & & $\mathrm{NA}$ & $\mathrm{NA}$ & & \\
\hline $180 \mathrm{~N}$ & & & & $\mathrm{X}$ & \\
\hline & & & & $\mathrm{X}$ & \\
\hline $200 \mathrm{~N}$ & $\mathrm{NA}$ & 0,52 & $\mathrm{NA}$ & & \\
\hline & 0,49 & 0,57 & & & \\
\hline & & $\mathrm{NA}$ & & & \\
\hline & & & & & \\
\hline $240 \mathrm{~N}$ & & & & $X$ & \\
\hline & & & & $X$ & \\
\hline $250 \mathrm{~N}$ & & $\mathrm{NA}$ & & & \\
\hline
\end{tabular}

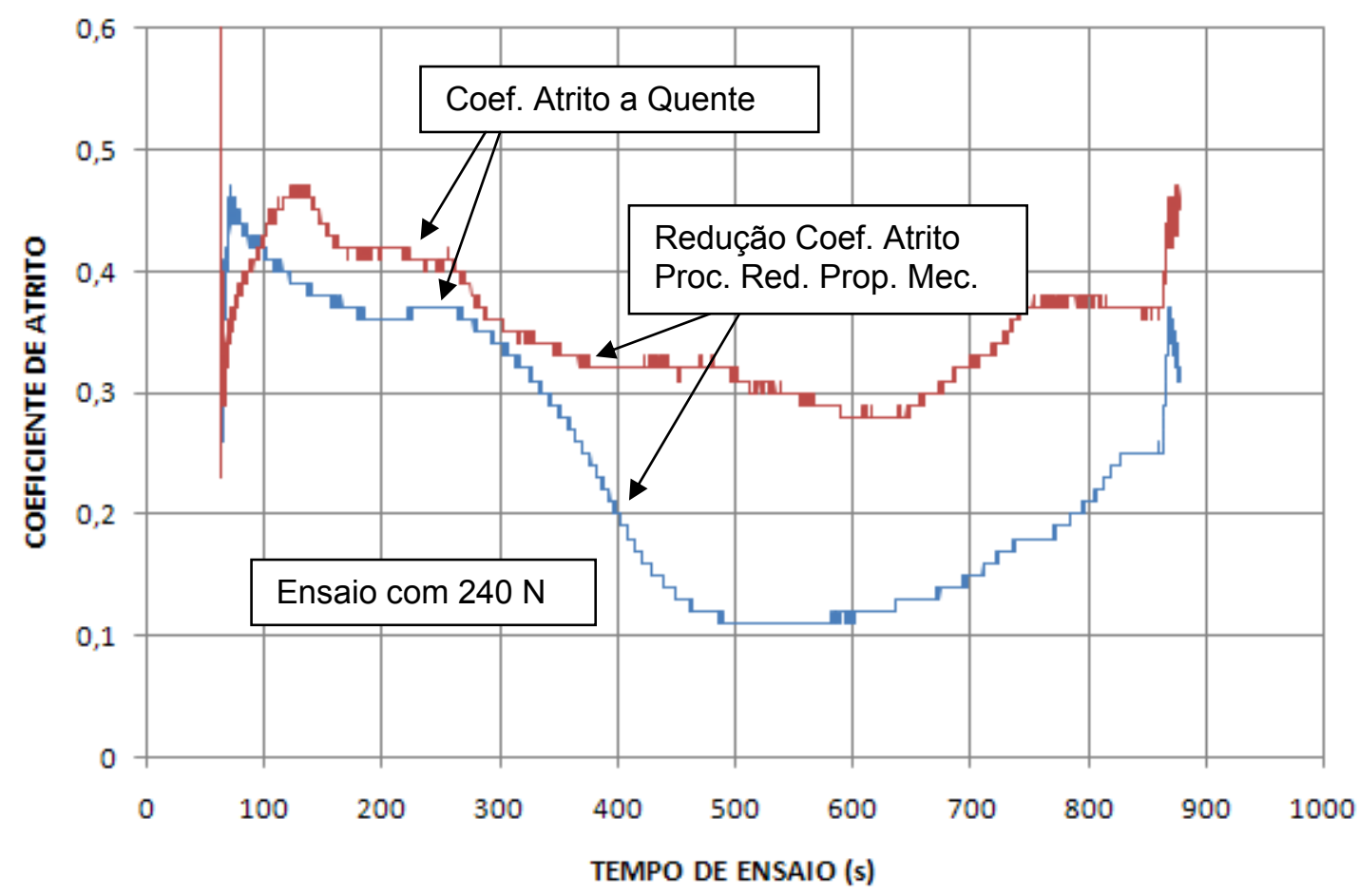

Figura 5.40: Variação do coeficiente de atrito em ensaios. 


\section{8 - EXTRAPOLAÇÃO RESULTADOS ENSAIOS PINO-DISCO}

Os resultados apresentados em 5.1, 5.2, 5.5 e 5.6 podem ser combinados, como é apresentada em forma de gráfico na fig. 5.41 .

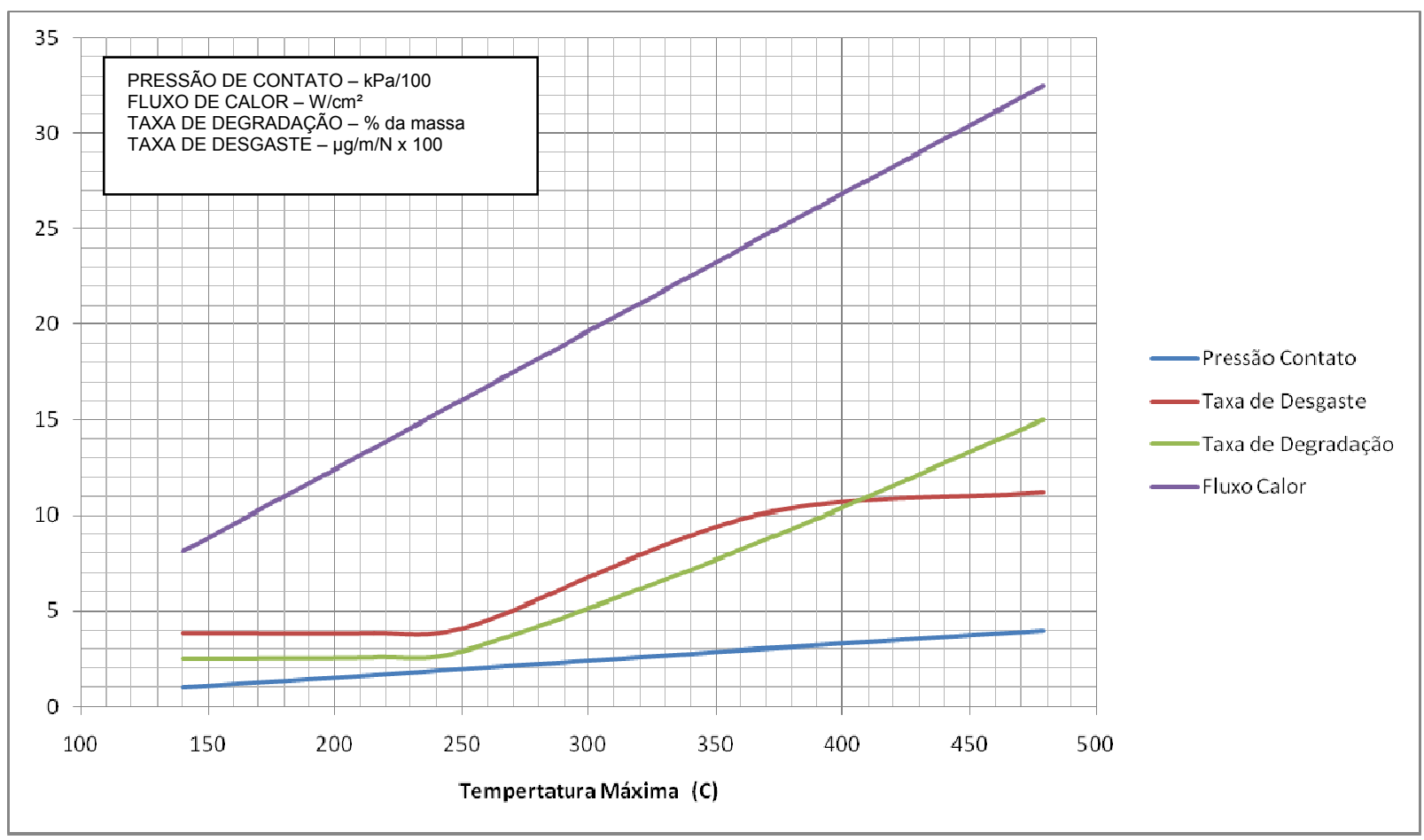

Figura 5.41: Resultados consolidados de simulações e ensaios.

Notamos o crescimento da curva da taxa de desgaste semelhante à curva da taxa de degradação. A ocorrência desse fato se dá a $235{ }^{\circ} \mathrm{C}$, o limite para uso fornecido pelo fabricante é de $200{ }^{\circ} \mathrm{C}$, estão mostrando a coerência entre os resultados, já que sempre os limites de catálogo são abaixo dos reais.

Como dito anteriormente a pressão de contato influencia diretamente na temperatura, e na taxa de desgaste. Porém não é exato extrapolar diretamente os resultados, sugere-se que a extrapolação seja feita pelo fluxo de calor. Dentro das limitações do equipamento utilizado para ensaios a velocidade do raio médio do corpo de prova deve ser o mais próximo da velocidade do raio médio da lona na embreagem. O ângulo do corpo-de-prova deve ser próximo ao ângulo de escorregamento da embreagem quando do engate. Do gráfico semelhante ao mostrado na figura 5.54, levantado para a aplicação em estudo escolhe-se o fluxo térmico máximo para projeto. Dos gráficos de coeficiente de atrito obtidos nos ensaios utiliza-se o coeficiente de atrito a quente obtido para 
a pressão de contato do corpo-de-prova (conforme 5.5). Sabendo-se o torque nominal da embreagem, inércias, etc. pode-se simular a embreagem de modo que se escolha o par ótimo de área de contato e pressão de contato para o projeto.

Normalmente os valores do fluxo de calor para esse tipo de aplicação com alto número de inserções por minuto são $10 \%$ a $30 \%$ inferiores aos sugeridos por Wright (2007). 


\section{6-CONCLUSÂO}

A hipótese levantada no capítulo 3 foi confirmada de diversas formas no capítulo 5. A importância do ensaio pino-disco foi mostrada também no capítulo 5. Em 5.8 foi analisado como transferir resultados destes ensaios para a aplicação prática em engenharia, que seria a definição da pressão de contato limite e a estimativa do desgaste da lona.

Para as fotos da UC 1000 das fig. 1.1 e 1.2, a pressão de contato é de 350 $\mathrm{kPa}, 50 \%$ do máximo recomendado por Spotts que é de 100 psi ou $700 \mathrm{kPa}$. A máquina foi projetada para intervalo entre inserções de $6 \mathrm{~s}$ e seu uso foi com intervalo de $3 \mathrm{~s}$ entre inserções. A fig. 6.1 mostra o ponto de projetos das duas prensas e ponto de operação da UC 1000, baseados no fluxo térmico (a pressão de contato do gráfico é válida apenas para o corpo-de-prova).

Interessante notar, no caso da UC 1000, que com o dobro de inserções por minuto, dobra-se o fluxo de calor, com isso a taxa específica de desgaste triplica. A manutenção foi executada após cinco meses de uso, caso estivesse operando nas condições de projeto a vida seria bem superior.

Uma das diferenças que existem em lonas de uso automotivo e lonas para o caso específico é o número de inserções e o tempo entre inserções. No embreamento ou frenagem existe um significativo calor gerado no escorregamento, elevando as temperaturas das lonas. Porém no caso automotivo existe um intervalo entre cada aplicação que permite o resfriamento da lona e no caso de prensas esse intervalo é muito curto e a lona aquece gradativamente até se atingir um regime permanente. Esse fenômeno é dependente da força aplicada à embreagem, tempo entre inserções e troca térmica efetiva.

Para projeto de embreagens os números existentes na literatura não se aplicam indistintamente, é necessária uma avaliação da temperatura final de operação da embreagem e a área de contato deve ser aumentada de modo a permitir a dissipação do calor gerado na operação.

Em embreagens com problemas atualmente existe a opção da inclusão de uma ou mais lamelas para o aumento da área de contato e redução da temperatura. 
É recomendável para a escolha da lona, seu ensaio de modo a se levantar sua taxa de desgaste para diversas cargas.

Em prensas devem-se dimensionar as espessuras das lonas para uma vida útil superior a um ano. Conforme o desgaste ocorre, as molas são mais pressionadas no caso de embreagens e menos pressionadas no caso de freios e o projeto deve levar em conta essas variações.

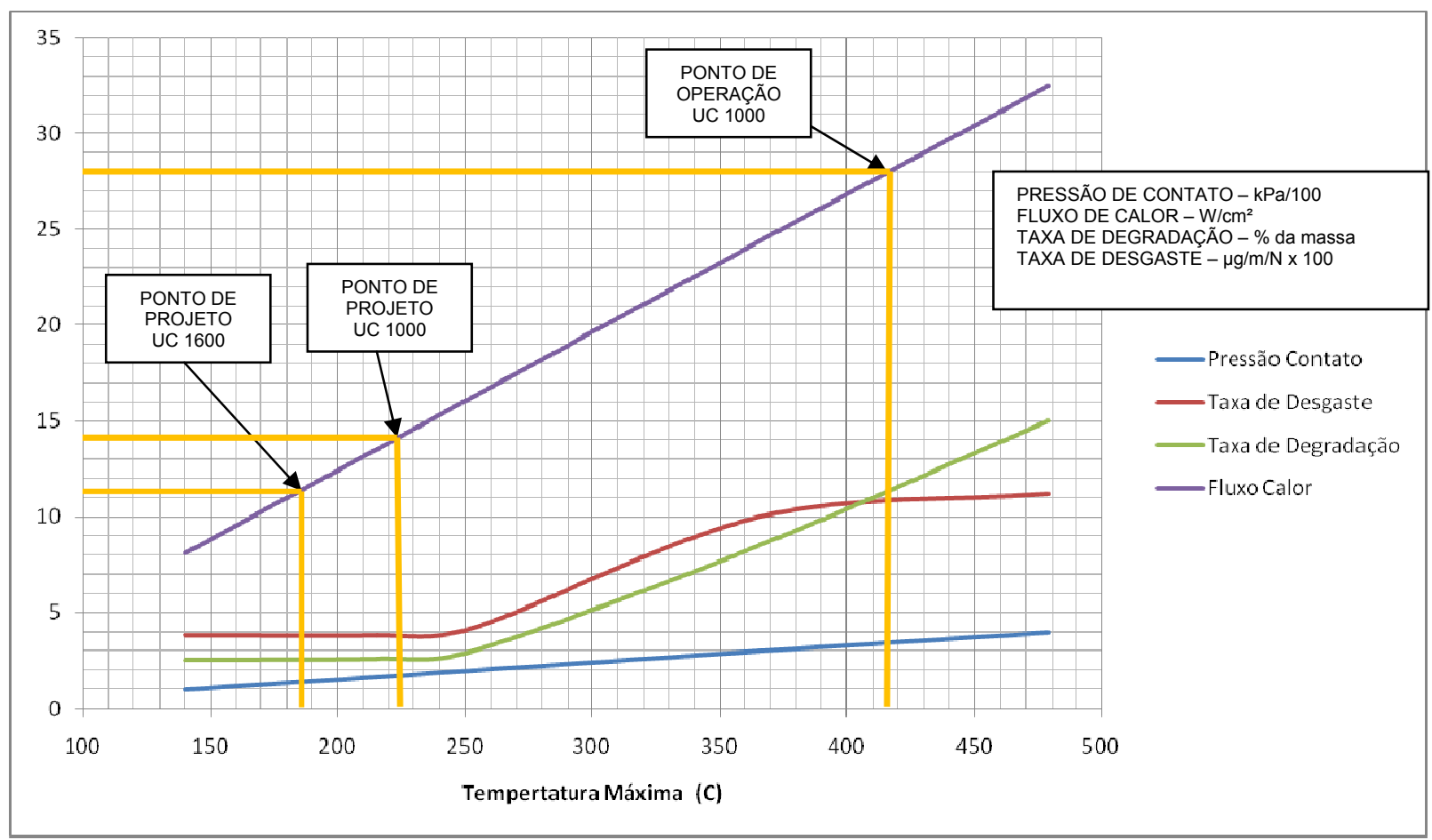

Figura 6.1: Pontos de projeto e operação da UC1000 e UC 1600.

A utilização prática desse trabalho pode ser feita pelo ensaio em pino sobre disco da lona a ser utilizada no projeto de uma nova embreagem. De maneira semelhante quando em manutenção houver a necessidade do uso de lona outro fornecedor. Ensaia-se a lona com velocidades o mais próximo possível das de operação (normalmente próximas a máxima do equipamento). Caso utilize corpos-de-prova com as dimensões apresentadas neste trabalho, recomenda-se variar a carga no intervalo de 60 a 240 N. Dos ensaios se obtêm os coeficientes de atrito e mede-se perda de massa do corpo-de-prova. Para a transformação dos resultados em um gráfico similar ao mostrado na fig. 6.1 é necessário obter-se as temperaturas da face da lona. Recomenda-se a utilização de uma simulação como feito no item 5.6. É interessante a medida da temperatura em um ou mais pontos durante os ensaios em pontos do suporte 
do corpo-de-prova para a calibração do modelo de elementos finitos (verificar o coeficiente de película utilizado). Medidas próximas a interface podem ser obtidas, ao invés de se utilizar as obtidas por simulação, mas alerta-se que por ser este um processo com grande geração de calor, o posicionamento do termopar é muito importante. Na fig. 5.50, afastando-se da superfície a temperatura cai bruscamente, então o afastamento do termopar da superfície pode indicar temperaturas muito inferiores. A utilização de temperaturas inferiores às reais, por erros de medida, pode levar ao deslocamento da curva de desgaste específico (fig.6.1) para a direita.

Convém notar que esse trabalho se baseia em lonas utilizadas para embreagens de prensas. Pode ser utilizado para outros casos, porém o que é importante ressaltar, para tipos semelhantes de lonas. Na hipótese o abrasivo se aquece mais que a base polimérica, isso é válido para abrasivos que sejam bons condutores de calor, absorvendo junto com o contra-corpo o calor gerado na interface. Para abrasivos que sejam maus condutores de calor essa hipótese não é válida, pois o calor gerado na interface abrasivo/contra-corpo é absorvido em maior parte pelo contra-corpo e daí sendo transmitido a base polimérica e trocado por convecção com o meio, veja fig. 2.7 para as trocas por convecção. 


\section{7- REFERÊNCIAS}

1- AFT CHAMPION TECHNOLOGIES. Brake and clutch composite: catálogo. Eugene, 2005.

2- AIRFLEX EATON. Power presses, brakes \& shears: catálogo. Cleveland, 1997.

3- AJAX FORGING PRESSES. Bulletin 79-1: catálogo. Cleveland, 2005.

4- ASHBY, M. Processing and design engineering materials, an introduction to microstructures. Londres, Pergamon Press, 1992.

5- ASME. National historic mechanical engineering landmark - 50.000 t closed die forging press. Nova lorque, ASME, 1981.

6- BAHADUR, S. Fundamentals of friction and wear of automobile brake materials: "tutorial SAE". Warrendale, SAE, 2003.

7- BLAU, P. J. Compositions, functions, and testing of friction brake materials and their additives. Oak Ridge National Laboratory. 2001. ORNL/TM-2001-64.

8- BRUNACCI. Freios: catálogo. São Paulo, 2005.

9- BRYDSON, J. A. Plastic materials an introduction to Materials engineering and science. Londres, Elsevier, 1999.

10-CARLSLILE INDUSTRIAL BRAKE \& FRICTION. Tech Data: catálogo. Bloomington, 2005.

11-CARVILL, J. Mechanical engineers data handbook. Oxford, Butterworth \& Heinemann, 2003.

12-COLLINS, J. Projeto mecânico de elementos de máquinas. Rio de Janeiro, LTC, 2006.

13-DESCH LUTEX KUPLUNGS. Desch drive technology: catálogo. Hannover, 2006.

14-FAIRES, V. M. Elementos orgânicos de máquinas. Rio de Janeiro, Livro Técnico e Científico Editora, 1975.

15-FRITEX. Asbestos moulded clutch facings: catálogo. Yaroslavi, 2005.

16-FRITEX, Non asbestos moulded clutch facings: catálogo. Yaroslavi, 2005.

17-GANGULY, A. Asbestos free friction composition for brake linings. MSRIT

POST, p. 560, M.S. Ramaiah Institute of Technology, Bangalore, 2007.

18-GOIZPER. Clutches \& Brakes: catálogo. Antzuola, 2006. 
19-GOPAL, L. Glass and carbon short fiber reinforcerd friction materials. Wear, 181-183, p. 913-921, 1995.

20-HALBERSTADT, L. E MANSFIELD J. A. An improved automotive brake lining using potassium titianate. Wear of materials, p. $560-568$, ASME, Nova lorque, 1977.

21-HOERBIGER. HC 150, Material Specification: catálogo. Peiting, 2006.

22-HOSFORD, W. Metal forming mechanics and metallurgy. Londres, Prentice Hall, 1983.

23-HUTCHINGS, I. M. Tribology friction and wear of engineering materials. Londres, Edward Arnold, 1992.

24-KEVLAR DUPONT. Aramid Fiber - Technical Guide: catálogo. Richmond, 2006.

25-KURIMOTO. C2F Features: catálogo. Osaka, 2009.

26-LINCH, J. Brake Linings Decomposition Products SCF-FORD-0600. Detroit, Ford, 1968.

27-LIU, J. study of transfer films and wear rates in friction materials. Wear of Materials, p. 595-600, ASME, Nova lorque, 1979.

28-LUDEMA, K. C., MENG, H. C. Wear Models and Predictive Equations: Their Form and Content. Wear 181-183, p. 443-457, 1995.

29-MAKELT, H. Mechanical presses. Norwich, Edward Arnold Publishers Ltd., 1968.

30-MARUSIC, V., VITEZ, I. Tribological properties of brake shoes. Metalurgija, v. 43, p. 323-327, 2004.

31-MOTT, R. L. Machine elements in mechanical design, New Jersey, Prentice Hall 1992.

32-NIEMANN, G. Elementos de máquinas. São Paulo, Edgard Blücher, 1971.

33-NORTON, R. L. Machine design. New Jersey, Prentice Hall, 1998.

34-ORTLINGHAUS GMBH. Pneumatic actuated clutch and brakes: catálogo. Wermelskirchen, 2006.

35-OSTERMAYER, G. P. On the dynamics of the friction coefficient. Wear, v. 254, p.852-858, 2003.

36-POGOSIAN, N., LAMBARIAN, A. Wear and thermal processes in asbestos reinforced friction materials. Wear of Materials, v- 101, p. 547-551, ASME, 1977. 
37-SOMAN, R. Preventive press maintenance. Metal Stamping, 1984.

38-PRITZELWITZ, P. V. Características especiais em prensas de forjar excêntricas. Porto Alegre, $28^{\circ}$ Senafor e $12^{\text {a }}$ Conferência Internacional de Forjamento, 2008.

39-RHEE, S.K. Wear equations of polymers sliding against metal surfaces. Wear, v. 16, p. 431-445, 1970.

40-RODRIGUES, A. A. R. Investigação das características tribológicas e ambientais de termoplásticos de engenharia especiais para uso em materiais de atrito. Tese (Doutorado) - Escola Politécnica da USP, 2007.

41-ROSS CONTROLS. DM2 Serpar, Bulletin 505: catálogo. Troy, 2006.

42-ROVETTA MANZONI GROUP. Presse Serie F: catálogo. Brescia, 1995.

43-SCHAEFFER, L. Conformação mecânica. Porto Alegre, Imprensa Livre, 1999.

44-SCHAEFFER, L. Forjamento introdução ao processo. Porto Alegre, Imprensa Livre, 2006.

45-SCHULER GMBH. Metal forming handbook. Brighton, The Machinery Publishing Company, 1966.

46-SCHULER GMBH. Metal forming handbook. Nova lorque, Springer Verlag, 1998.

47-SCHUMANN, M. Winner $\mathrm{H}$. Analysis method for assessing irregular brake disk wears on motor vehicle disk brakes. XXVIth International $\mu$ Symposium, p. 181215, Darmstadt Technical University, 2006.

48-SHIGLEY, J. E. Elementos de Máquinas. Rio de Janeiro, LTC, 1984.

49-SHIGLEY, J. E. Mechanical engineering design. New York, McGraw Hill, 1986.

50-SMERAL. Press type LMZ 1600: manual técnico. Brno, 1986.

51-SPOTTS, M.F. E SHOUP, T. E. Design of machine elements. New Jersey, Prentice Hall, 1998.

52-SPUR, R.T. Fillers in friction material. Wear, vol. 22, p. 367-409, 1972.

53-STACHOVIAK, G. Engineering tribology. Oxford, Butterworth \& Heinemann, 2000.

54-STACHOVIAK, G. W., CHAN D. Review of automotive brake friction materials.

Procedures Institute of Mechanical Engineers, v. 218, p. 953-966, 2004.

55-STOLARSKI, T. A. Tribology in machine design. Oxford, Butterworth \& Heinemann, 2000.

56-TECHNOCEL CFF. Native cellulose fibers: catálogo. Amstädter, 2006. 
57-TECHNORA TEIJIN. The power of aramides: catálogo. Westevoorsedijk, 2006. 58-THERMOFIBER. Protec friction supply: catálogo. Mount Kisco, 2006.

59-TRIMAT. Friction solutions: catálogo. Brierley Hill, 2006.

60-WARNER ELECTRIC. Basic design clutches/brakes: catálogo. South Beloit, 2006.

61-WICHITA DANA. Clutches \& brakes: catálogo técnico. Wichita falls, 2001.

62-WRIGHT, D. Brakes: overview, dynamics, materials. University Western Australia 2007.

63-www.dcita.gov.au/cca - NICNAS chrisolite asbestos full public report.

64-www.matweb.com - Hexion EP 8412 epoxi resin.

65-www.matweb.com - Mitsui Milex RS 2210MB silicon rubber modified phenolic resin.

66-www.matweb.com - Mitsui Milex RS 2410MB acrylic rubber modified phenolic resin.

67-www.matweb.com - Mitsui Milex RN 2830MB acrylic rubber modified phenolic resin.

68-www.matweb.com - Mitsui Milex RN 2830MR acrylic rubber modified phenolic resin.

69-www.matweb.com - Mitsui Milex RX 2325RC low silicone rubber modified phenolic resin.

70-www.matweb.com - Mitsui Milex straight novolak phenolic resin.

71-www.matweb.com - Tipco Tipcolite TPF 1115 thermoset phenolic resin. 


\section{ANEXO A - FOTOS DAS LONAS \\ PRIMEIRA BATERIA DE ENSAIOS}

Nas figuras 1.1 e 1.2 mostram uma coloração diferente dos resíduos. Sua coloração é associada ao regime de desgaste e a degradação da base polimérica. No capítulo 3 esse fato é comentado e apresenta-se uma teoria associando-a a um mapa de desgaste fig. 3.3. As figuras A.1 a A.5 mostram as fotos de lonas após ensaios.

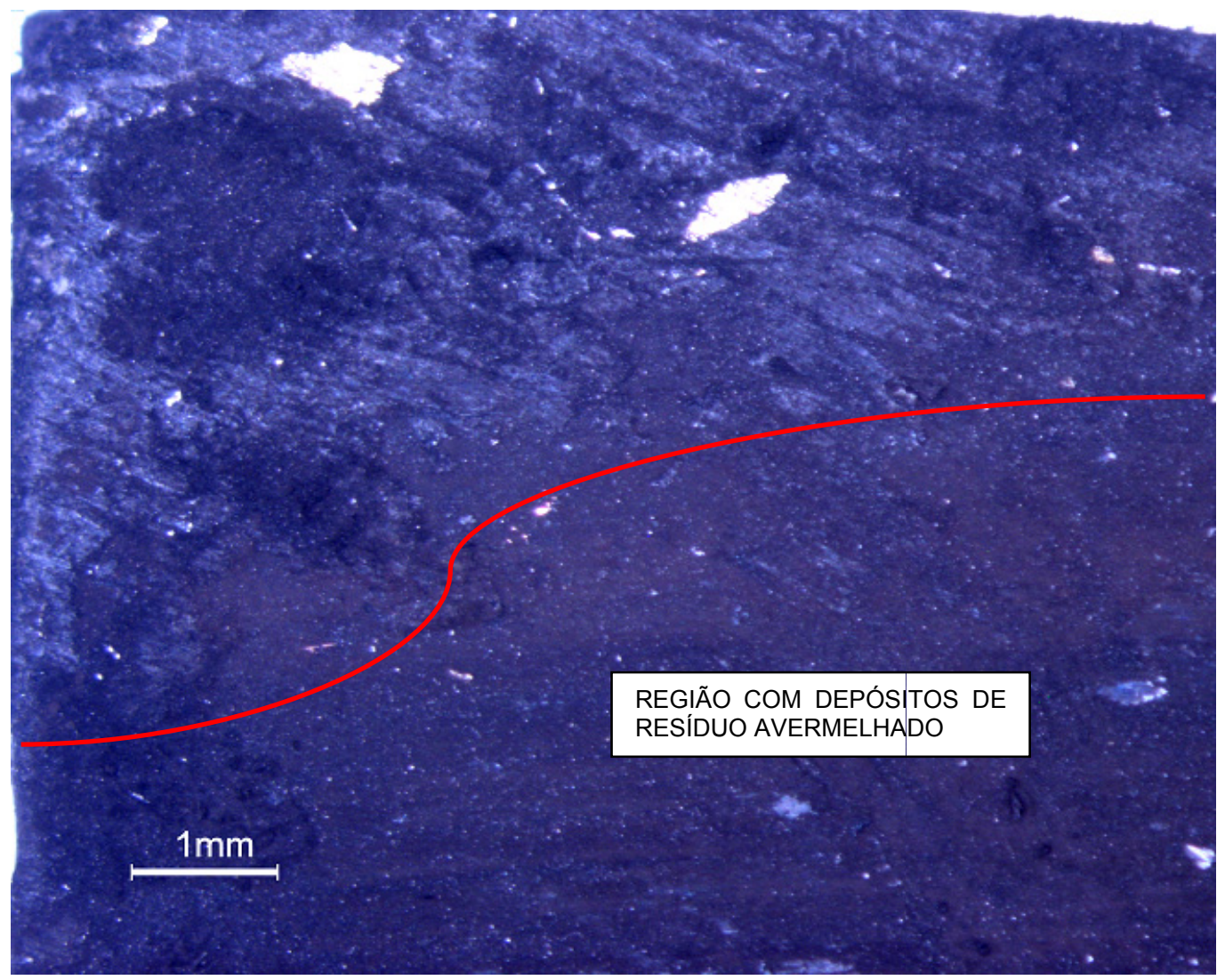

Figura A.1: Lona após ensaio a $100 \mathrm{~N}$ e 100 rpm, aumento $10 \mathrm{x}$. 


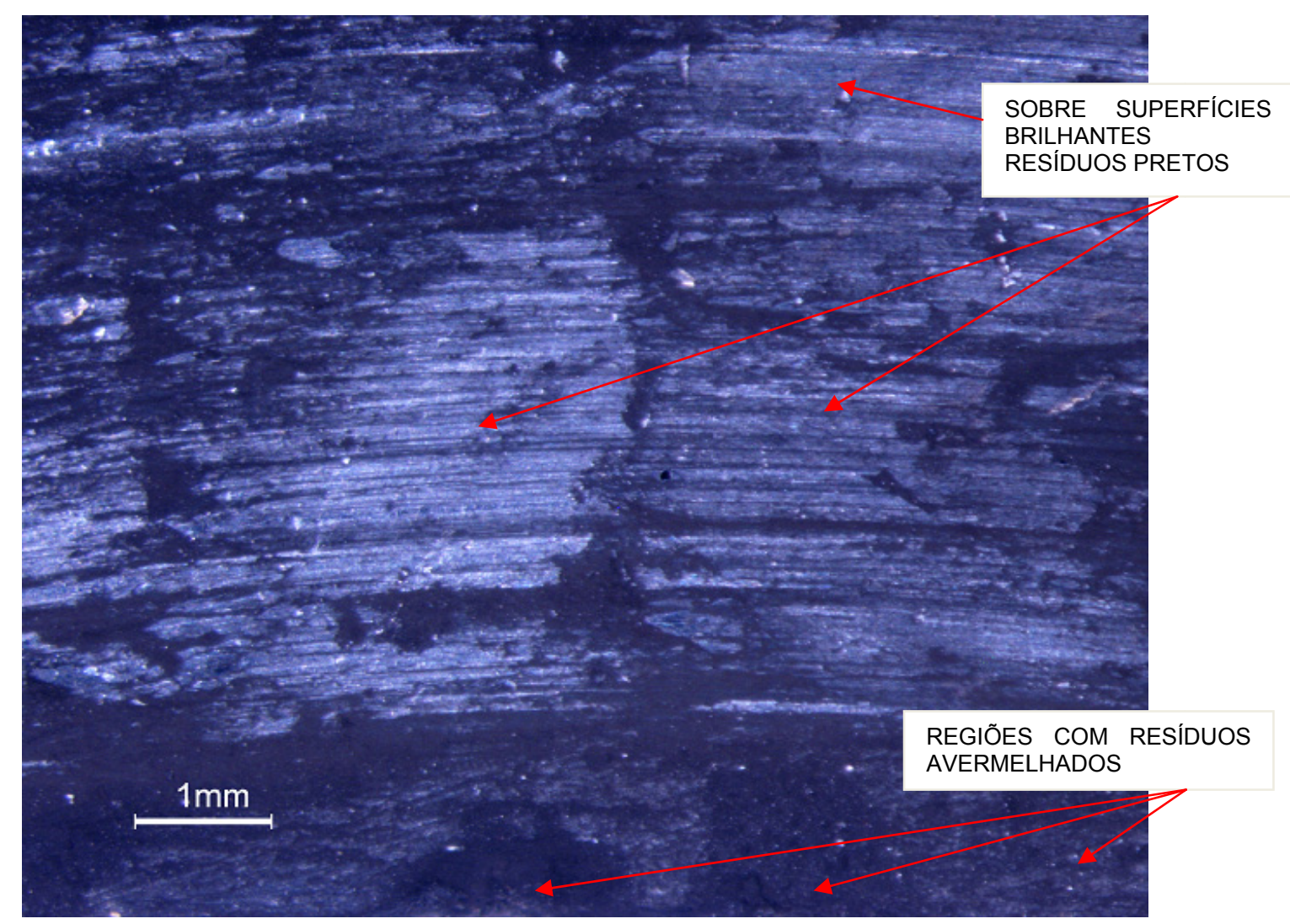

Figura A.2: Lona após ensaio a $100 \mathrm{~N}$ e 100 rpm, aumento $10 \mathrm{x}$.

$\mathrm{Na}$ lona da figura A.1 teve a formação dos resíduos avermelhados em parte da superfície, indicando algo semelhante ao mostrado nas figuras 1.1 e 1.2, infelizmente não está claro na foto.

$\mathrm{Na}$ lona da figura A.2 na parte inferior a formação de resíduos avermelhados e na parte superior formação de resíduos pretos, pela superfície não totalmente lisa, os pontos mais elevados sofrem maiores cargas, conseqüentemente maiores temperaturas na região e inicia-se um processo de degradação da base polimérica.

Em um ensaio a $1500 \mathrm{rpm}$ e a $200 \mathrm{~N}$, uma condição bem mais severa que o anterior, com maior aquecimento do contra corpo e das fotos da lona, figuras A.3, A.4, A.5 e A.6. 


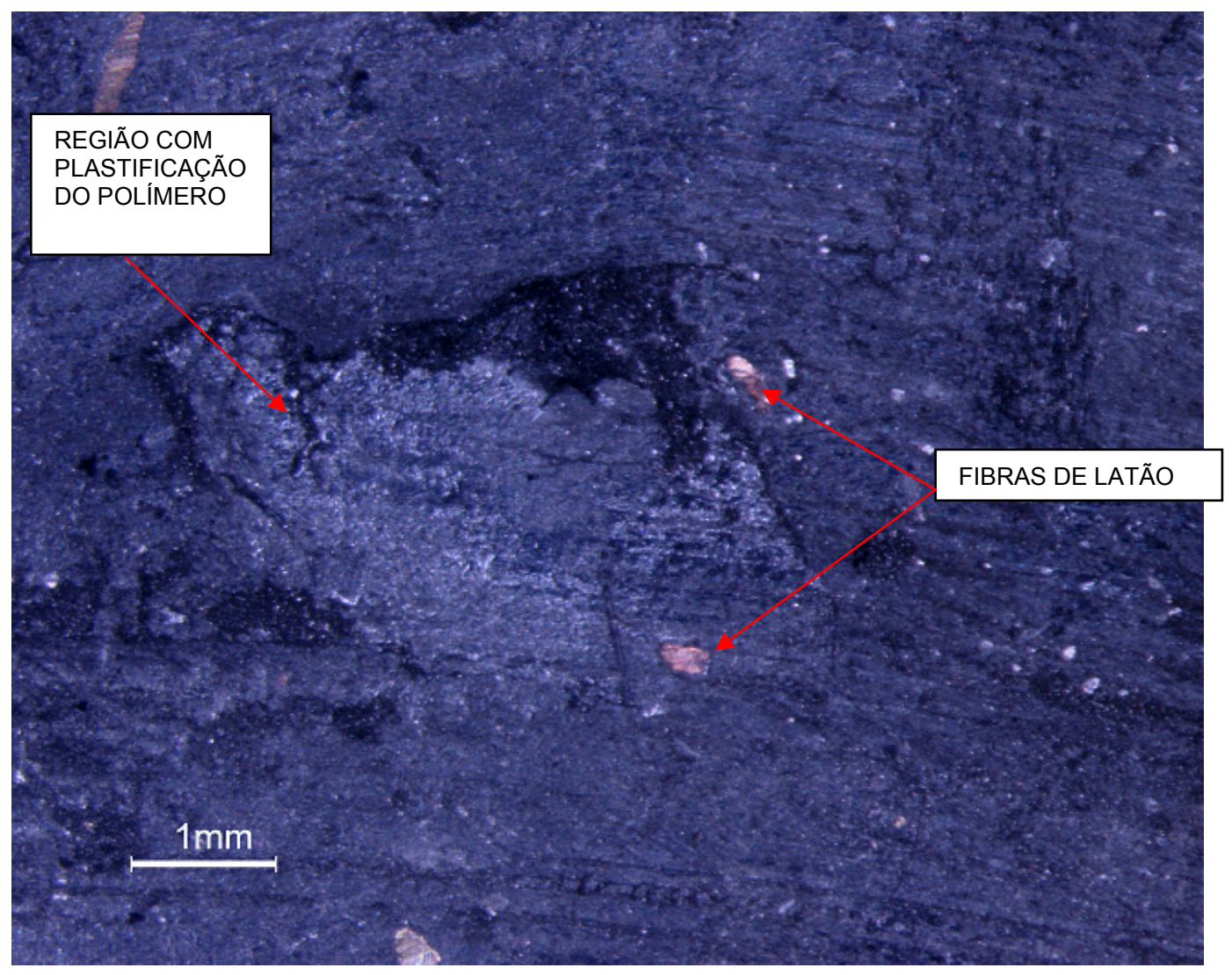

Figura A.3: Lona ensaio severo

Nas lonas das figuras A.3, A.4 e A.5 ocorreram apenas resíduos pretos, o material tem sua superfície bem lisa, parece haver derretido fechando quase que totalmente os vazios encontram em lonas novas (figuras 4.1 e 4.2).

Nas lonas das figuras A.4 e A.5 vemos partes das fibras recobertas pelo que parece base polimérica.

A região da figura A.6 é uma região com menos fibras e nota-se um desgaste mais homogêneo da superfície, sem tantos pontos discretos metálicos, como nas anteriores, apesar de ser a mesma lona, houve menos pontos concentrados de alta temperatura, diminuindo o desgaste por degradação da base polimérica. 


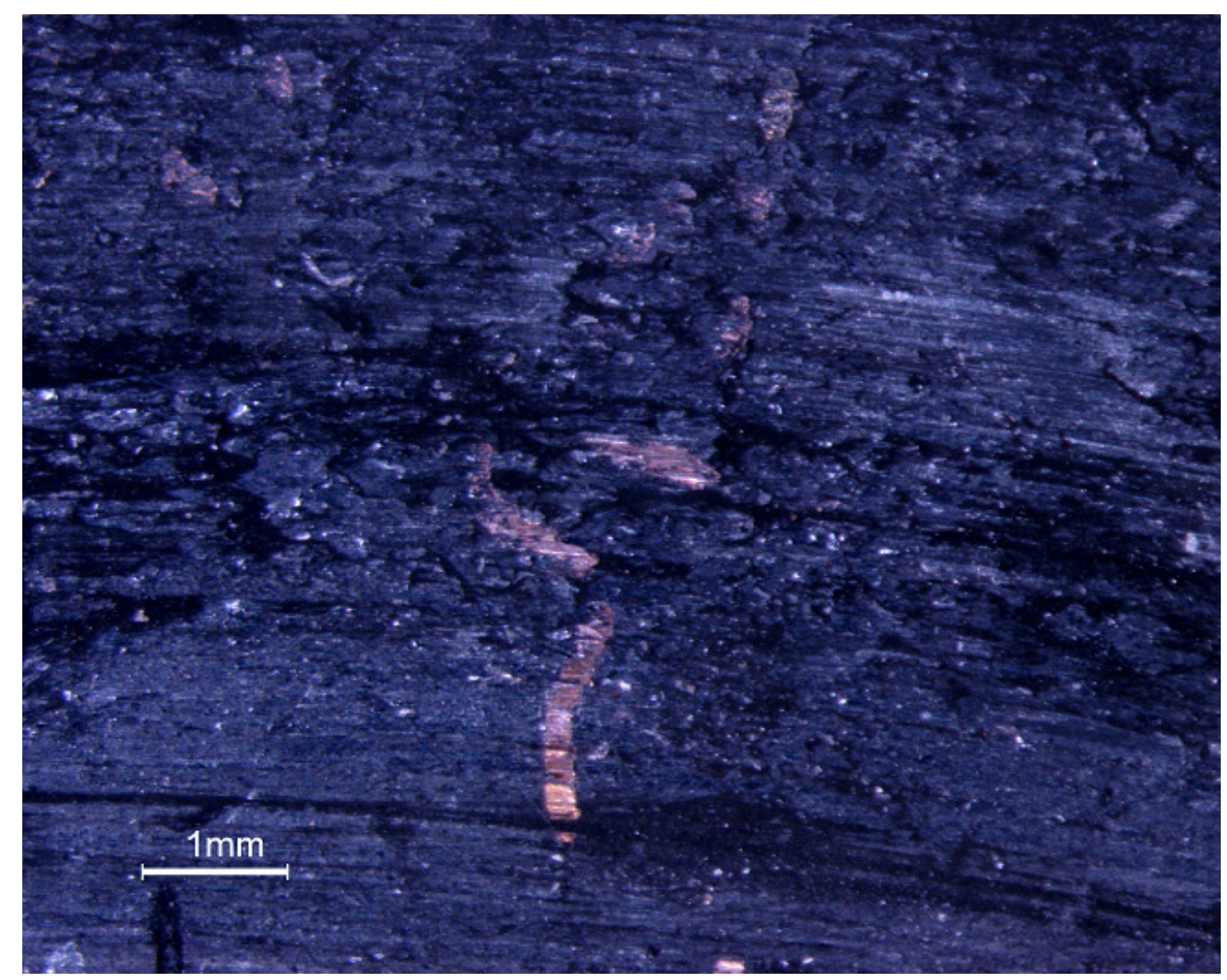

Figura A.4: Lona ensaio severo

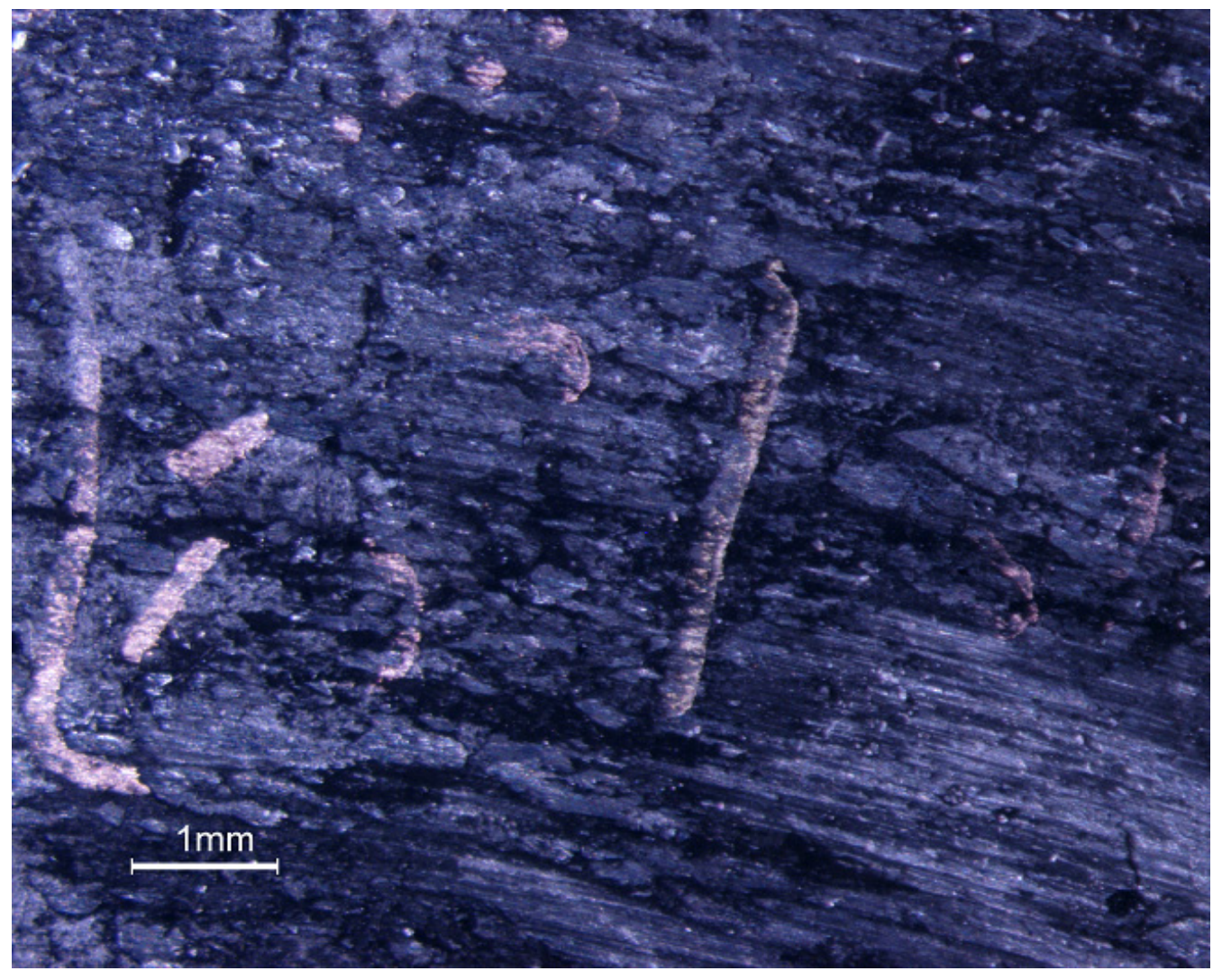

Figura A.5: Lona ensaio severo 


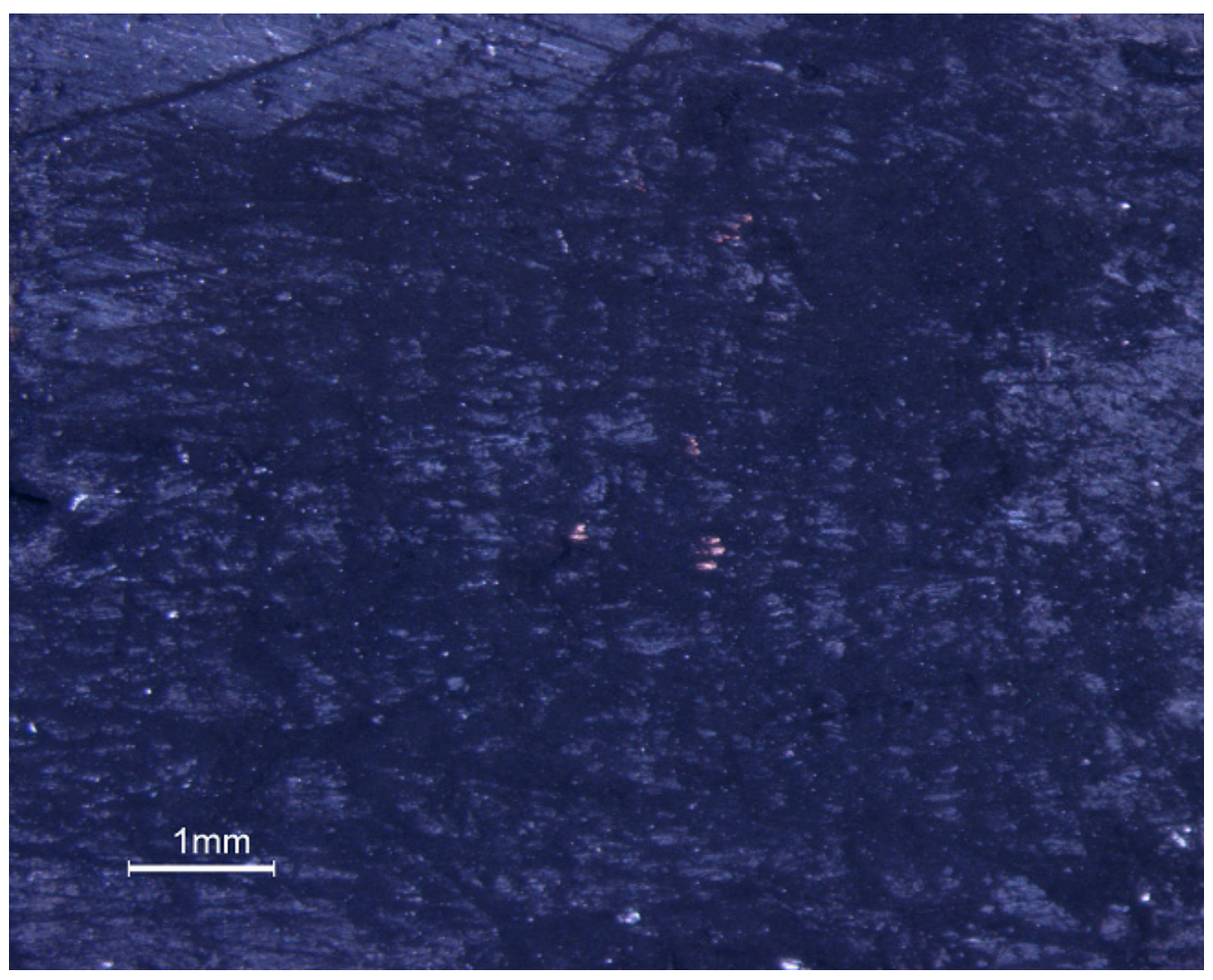

Figura A.6: Lona ensaio severo 


\section{ANEXO B - FOTOS DOS CONTRA-CORPOS}

PRIMEIRA BATERIA DE ENSAIOS

A trilha de contato dos contra-corpos é mostrada nas figuras B.1 a B.7.

Nas figuras B.1, B.2 e B.3 do mesmo disco (ensaio pouco severo) a coloração da trilha não se diferencia do material virgem a olho nu, porém nos riscamentos, há mudanças de coloração do violeta ao azul claro, pelas cores de revenimento, indicando temperaturas de riscamento ("flash temperatures") de $300^{\circ} \mathrm{C}$ ou superiores. Os riscos em diagonal são do lixamento da superfície. $\mathrm{Na}$ figura B.6 e B.7 do mesmo disco (ensaio severo) a coloração da trilha se diferencia do material virgem a olho nu, nos riscamentos há mudança de coloração do azul claro ao azul acinzentado, pelas cores de revenimento, indicando temperaturas de riscamento (flash temperatures) bem superiores à $300^{\circ} \mathrm{C}$.

Não existem mais os riscos em diagonal do lixamento da superfície.

A superfície tem uma aparência de "retificada".

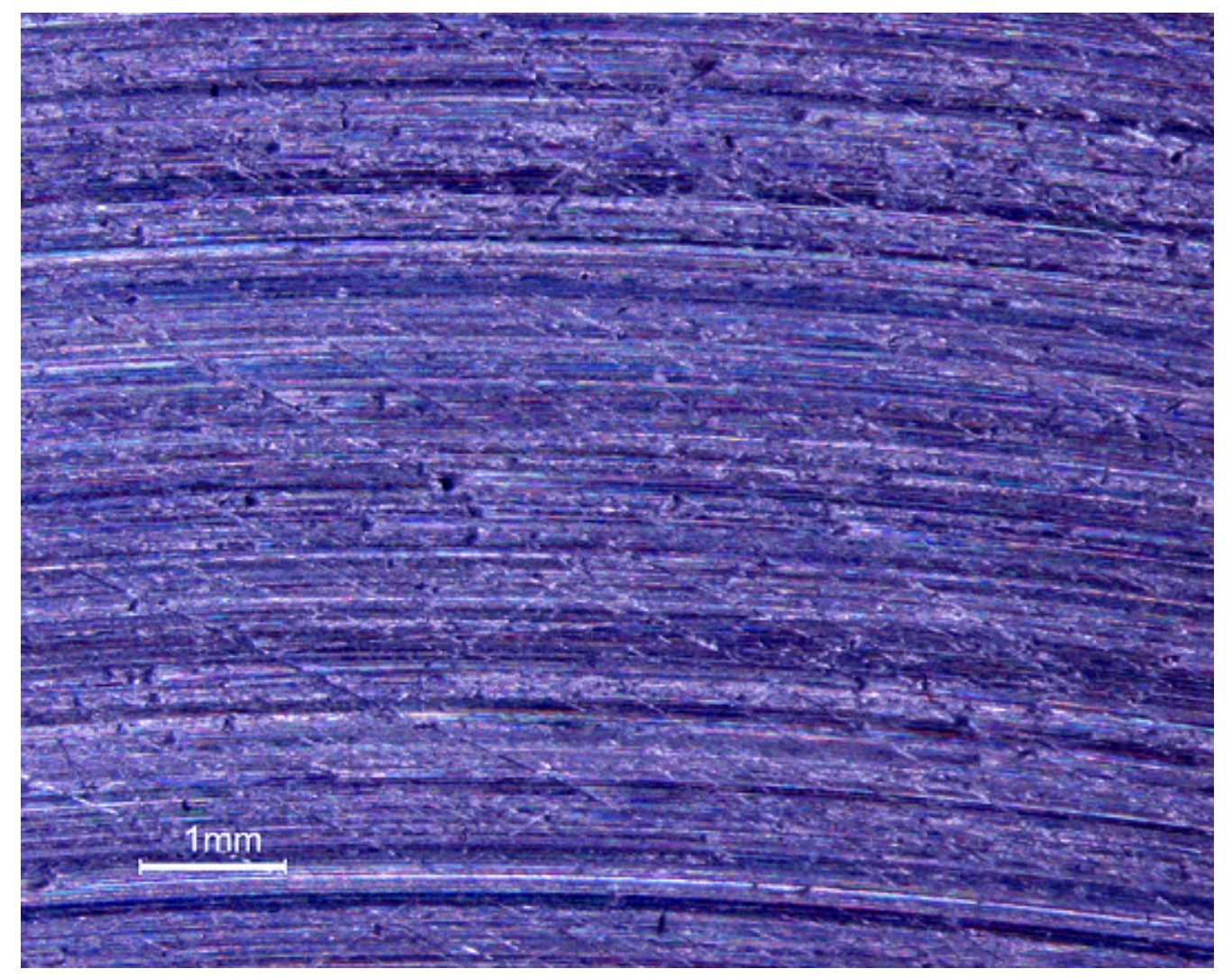

Figura B.1: Disco após ensaio a 100 N e 100 RPM, aumento 10 x. 


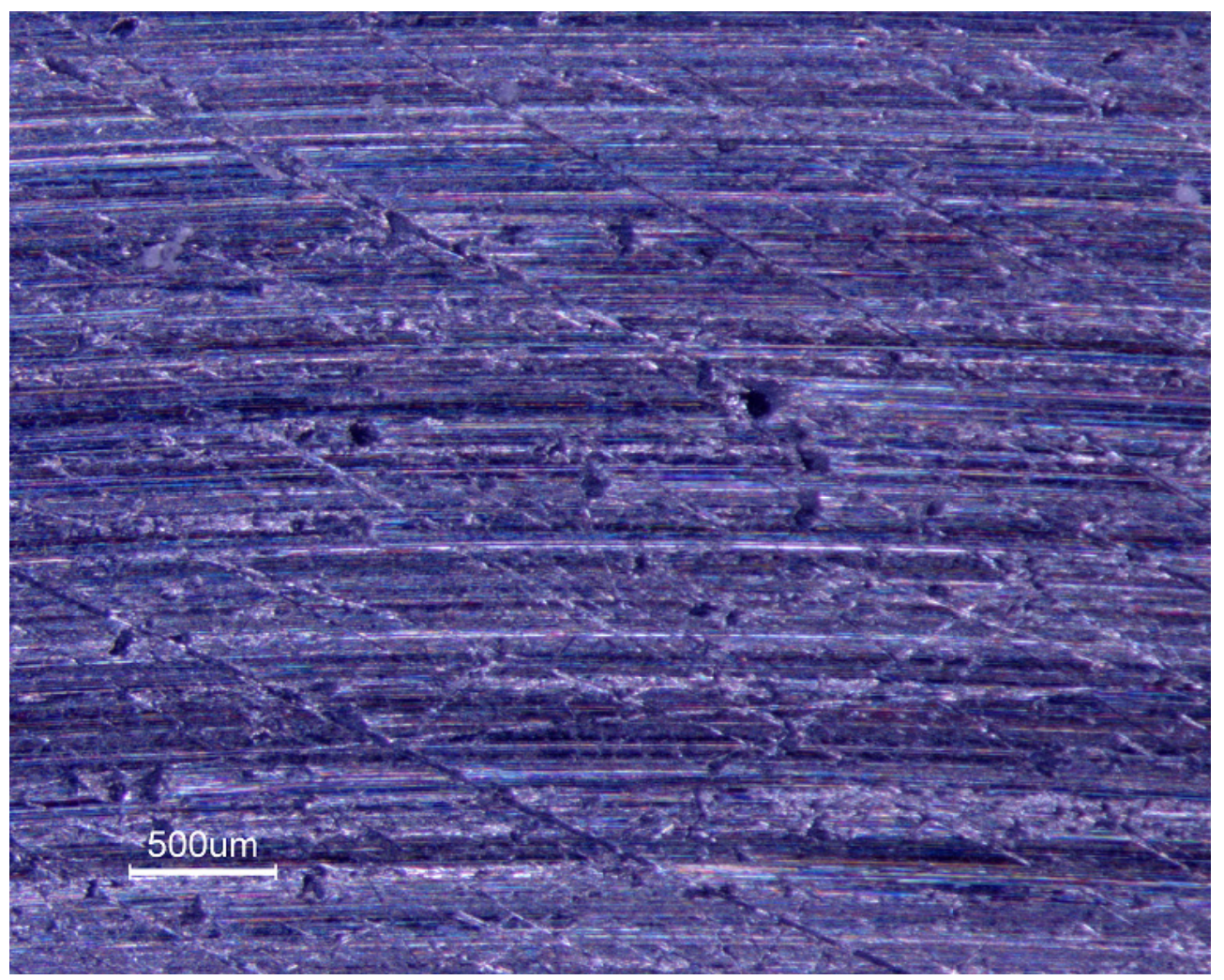

Figura B.2: Disco após ensaio a 100 N e 100 RPM, aumento 20 x.

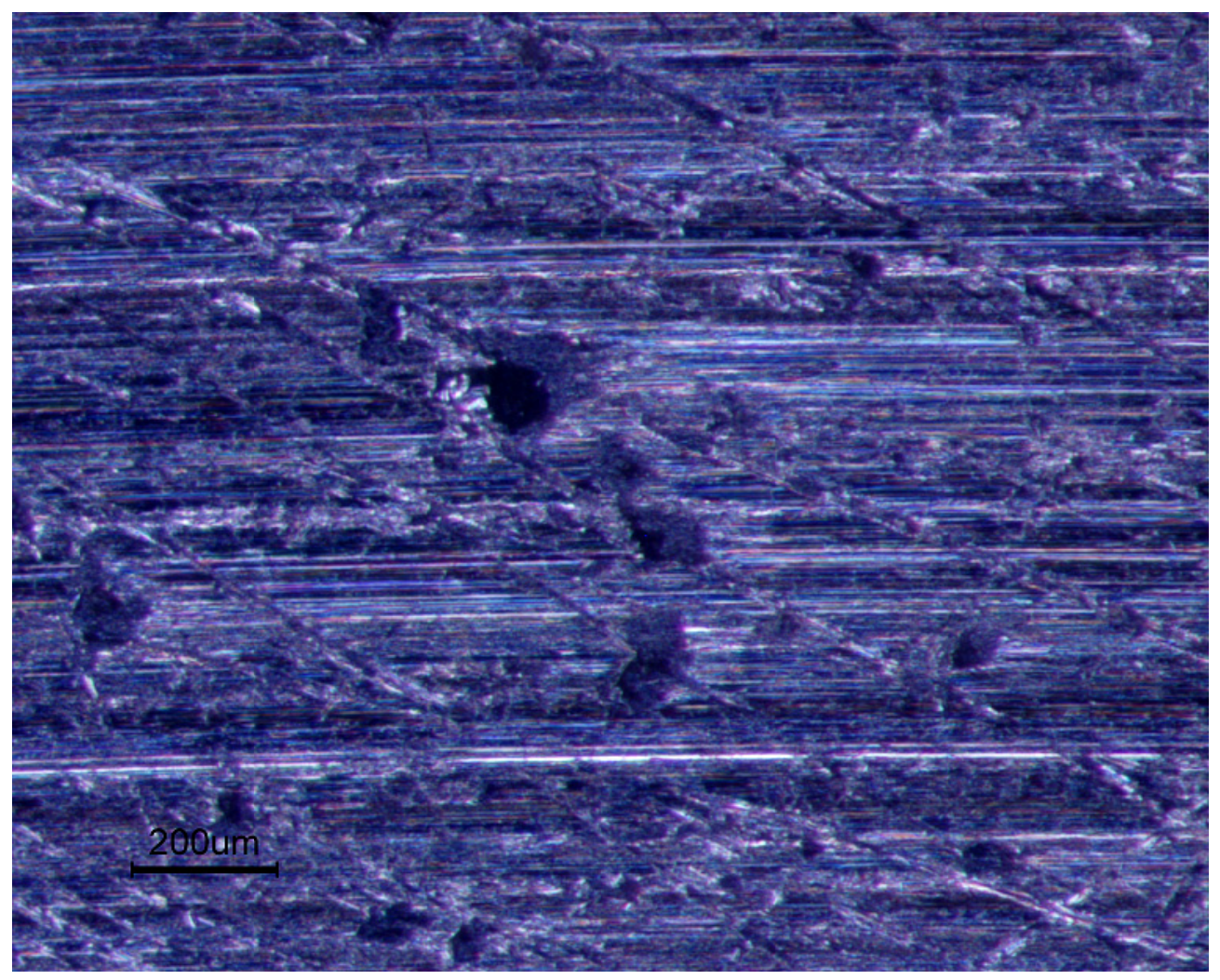

Figura B.3: Mesmo disco após ensaio a 100 N e 100 RPM, aumento 50 x. 


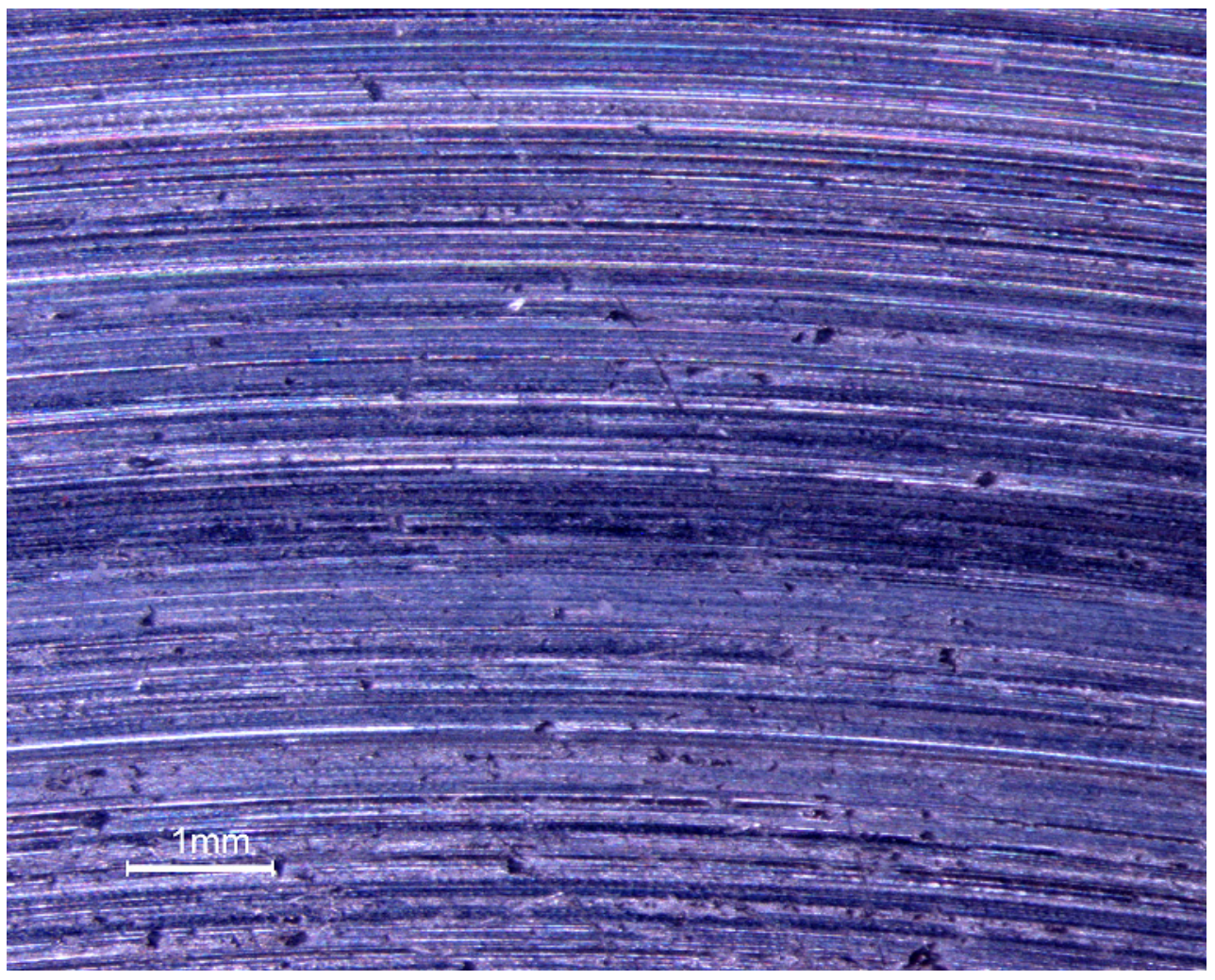

Figura B.4: Disco após ensaio a $100 \mathrm{~N}$ e 100 RPM, aumento 10 x.

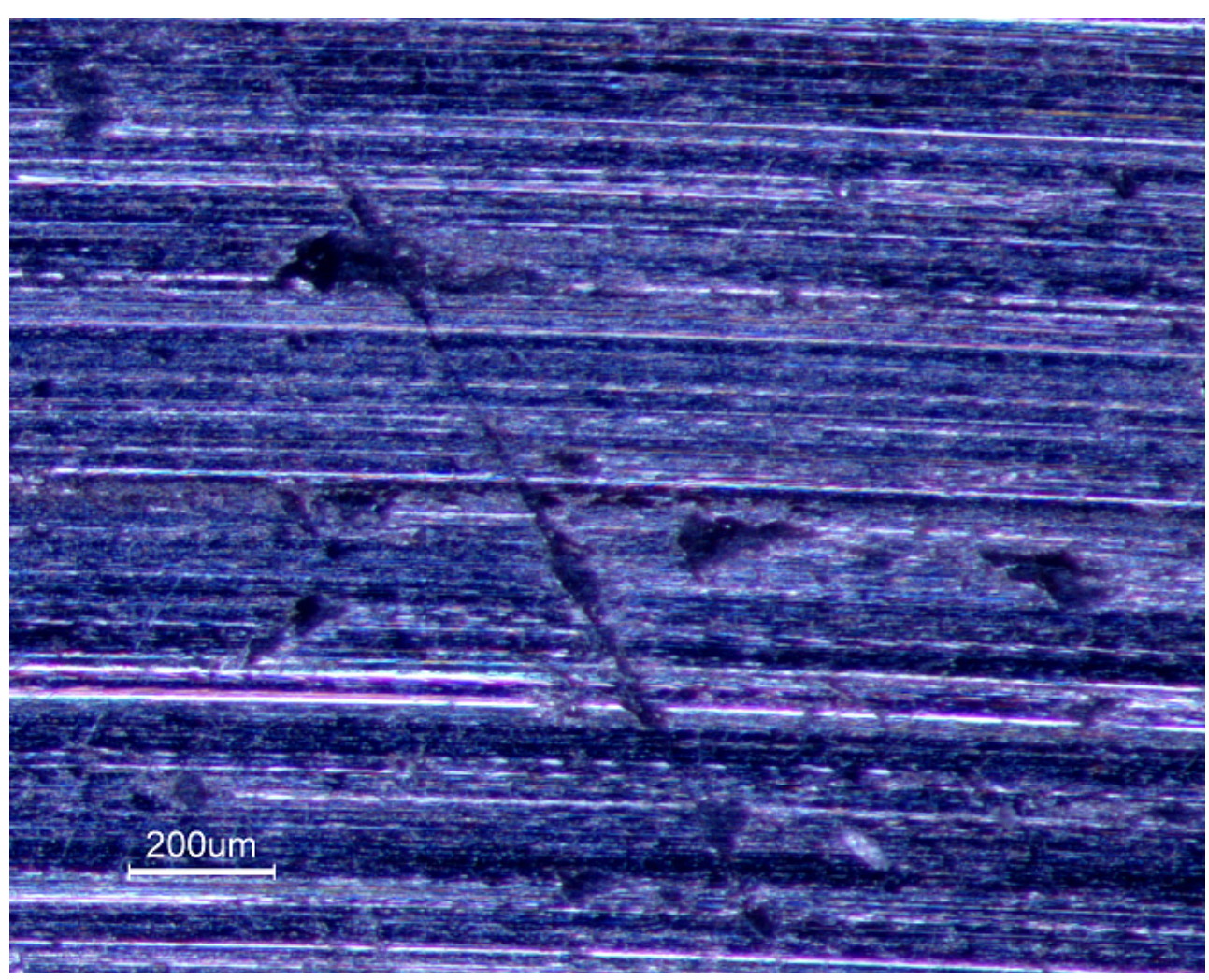

Figura B.5: Mesmo disco após ensaio a 100 N e 100 RPM, aumento 50 x. 


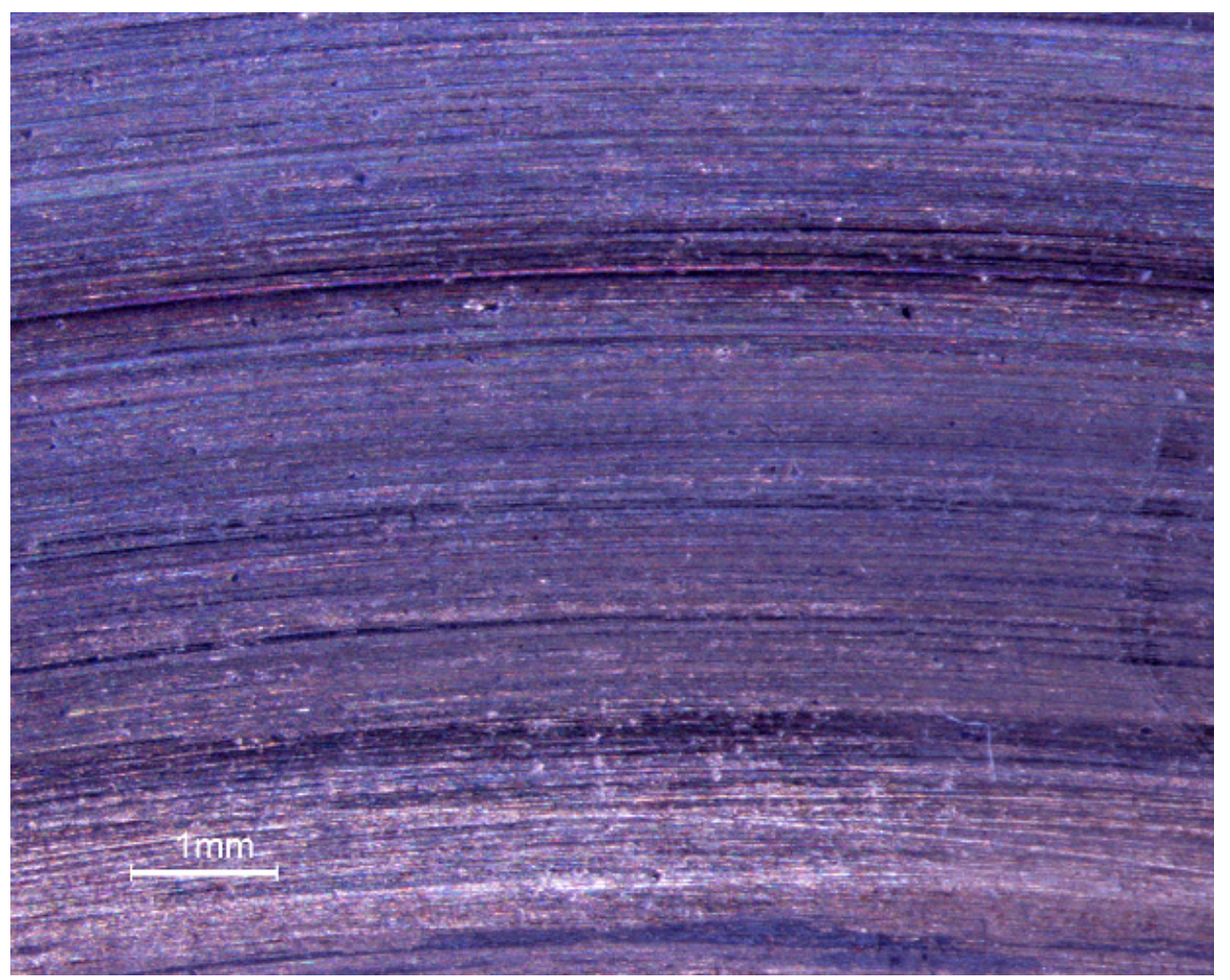

Figura B.6: Disco após ensaio a 200 N e 1500 RPM, aumento 10 x.

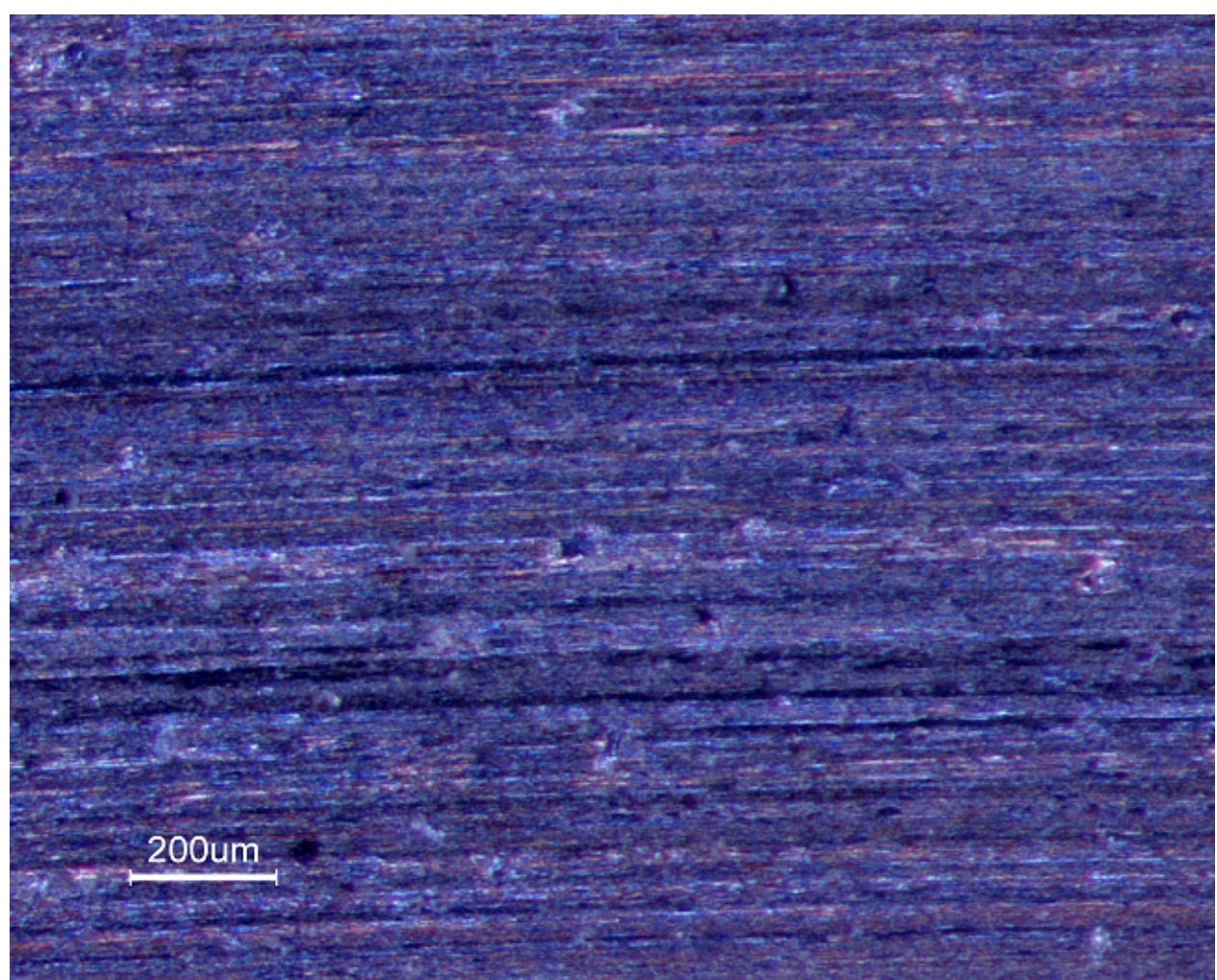

Figura B.7: Mesmo disco após ensaio a 200 N e 1500 RPM, aumento 50 x. 


\section{ANEXO C - FOTOS DOS CORPOS-DE-PROVA SEGUNDA BATERIA DE ENSAIOS}

- Ensaios com $60 \mathrm{~N}$ de carga e $1000 \mathrm{RPM}$

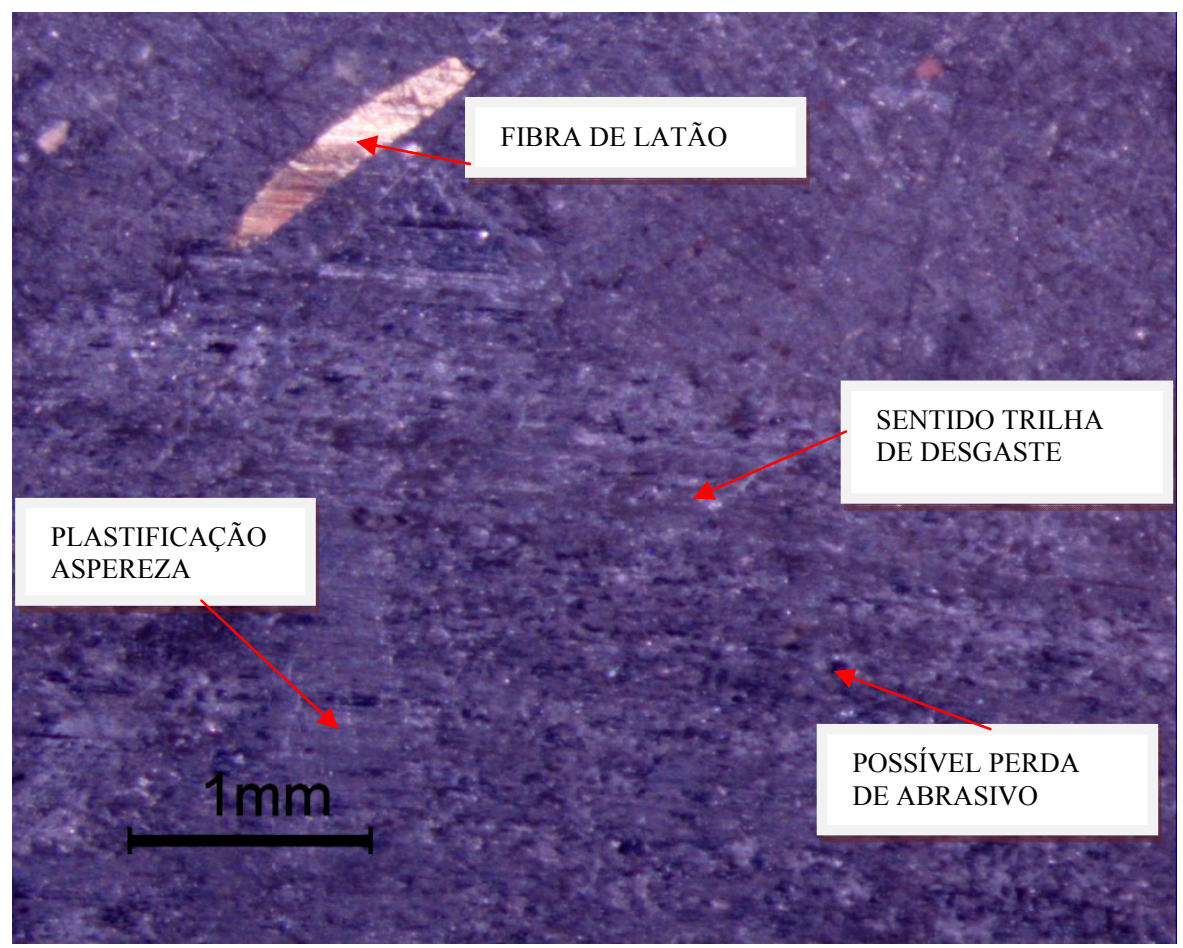

Figura C.1: CP 1 (ensaio $60 \mathrm{~N}$ de carga e $1000 \mathrm{RPM}$ ), foto 1.

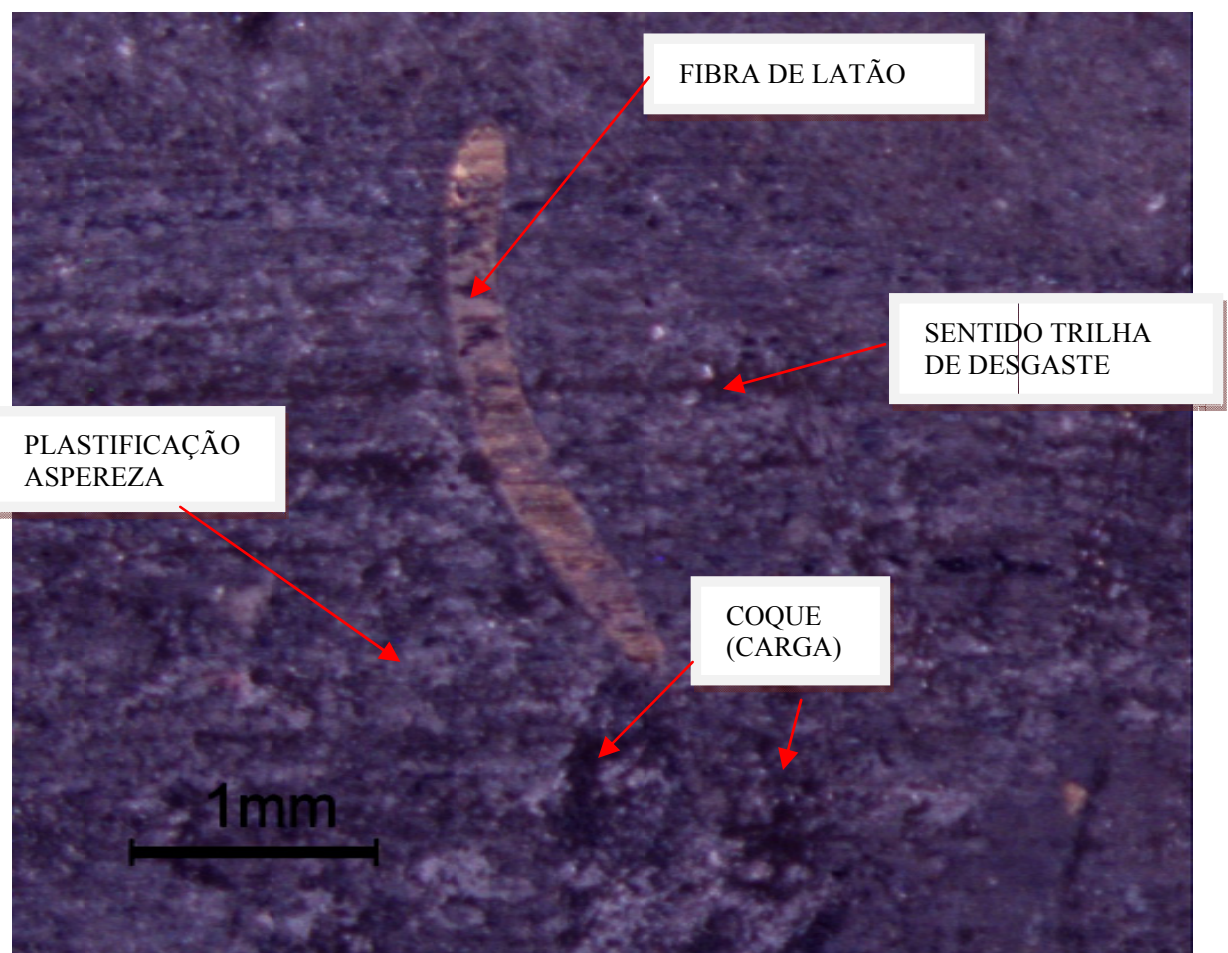

Figura C.2: CP 1 (ensaio $60 \mathrm{~N}$ de carga e $1000 \mathrm{RPM}$ ), foto 2 


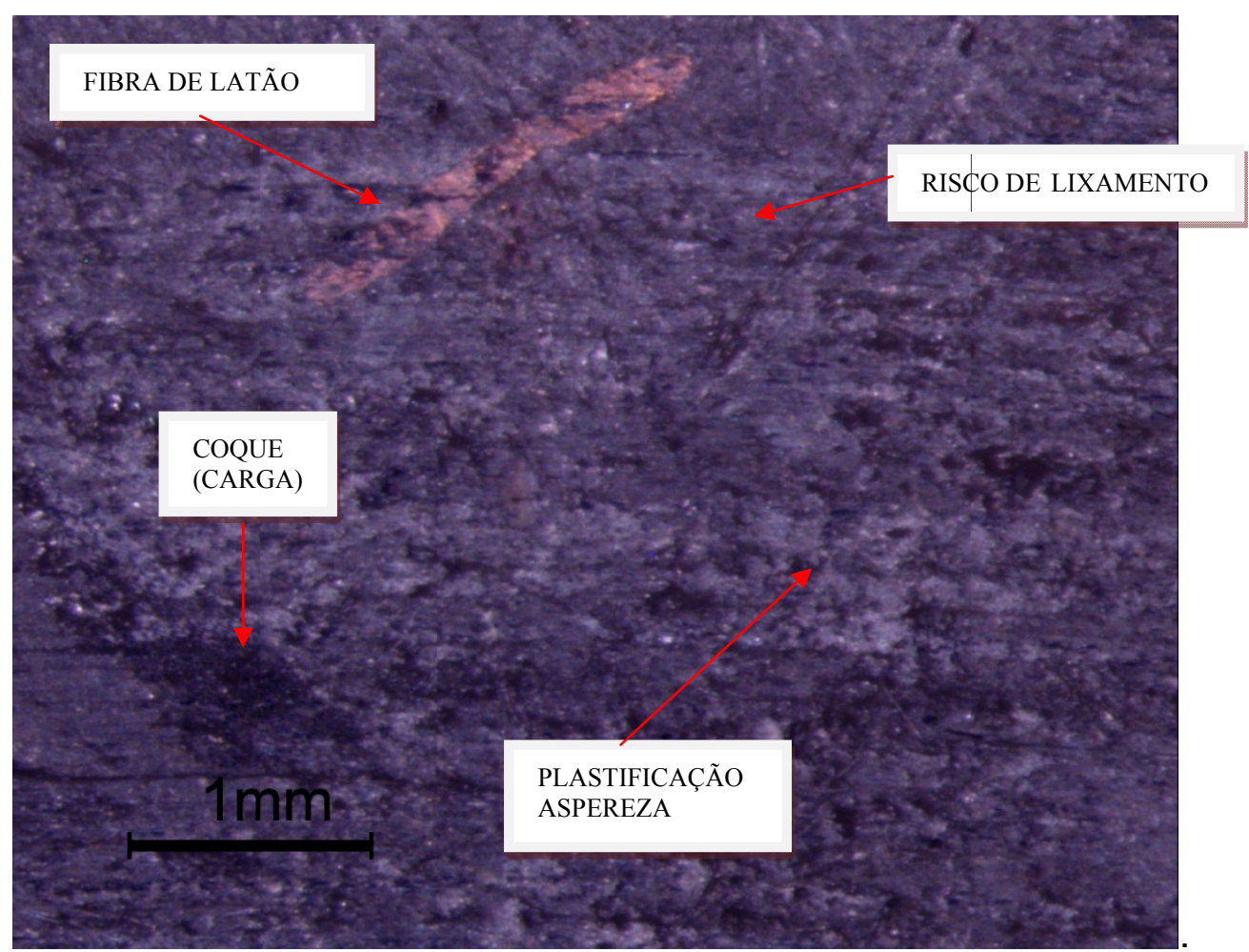

Figura C.3: CP 1 (ensaio $60 \mathrm{~N}$ de carga e 1000 RPM), foto 3

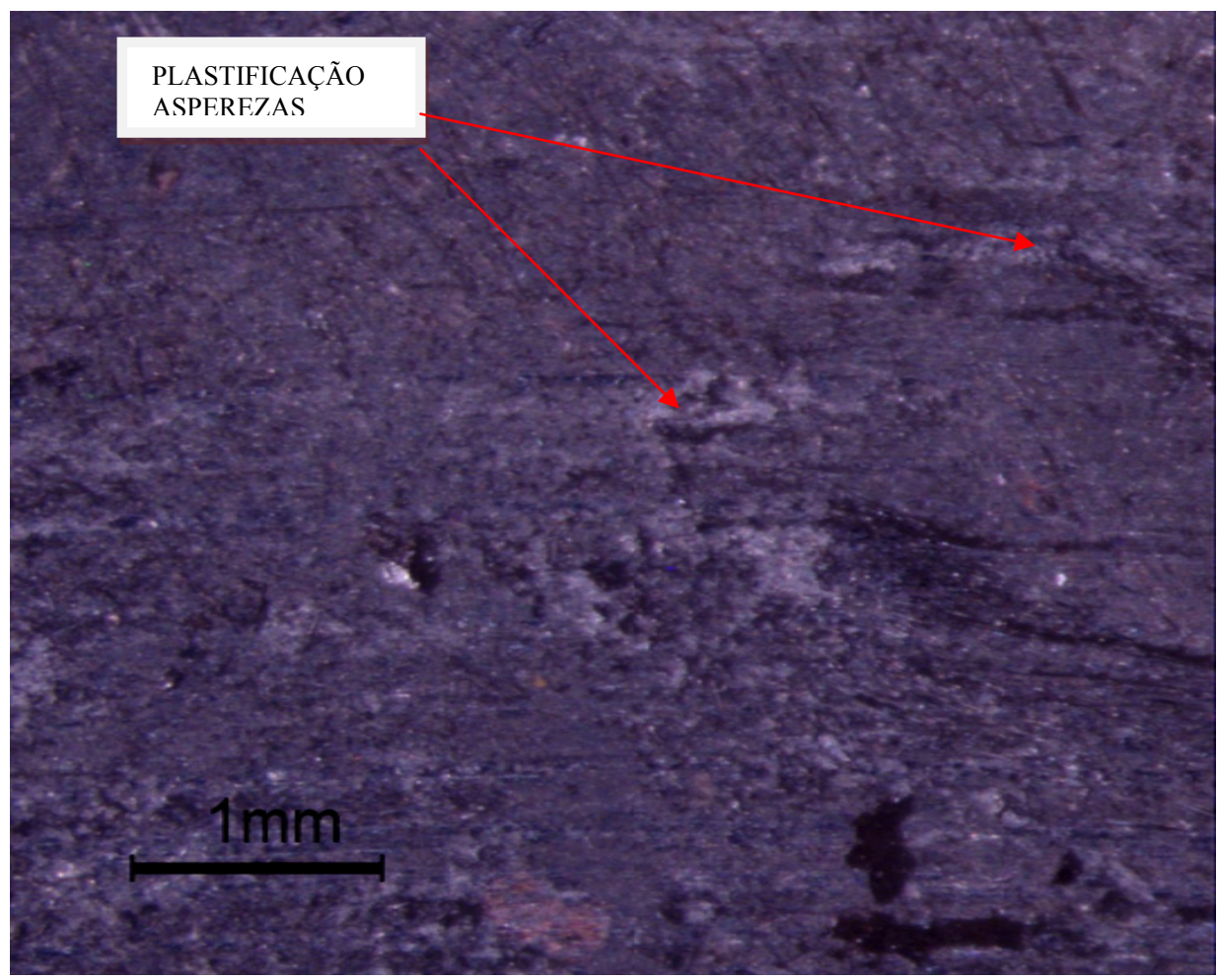

Figura C.4: CP 1 (ensaio $60 \mathrm{~N}$ de carga e 1000 RPM), foto 4 


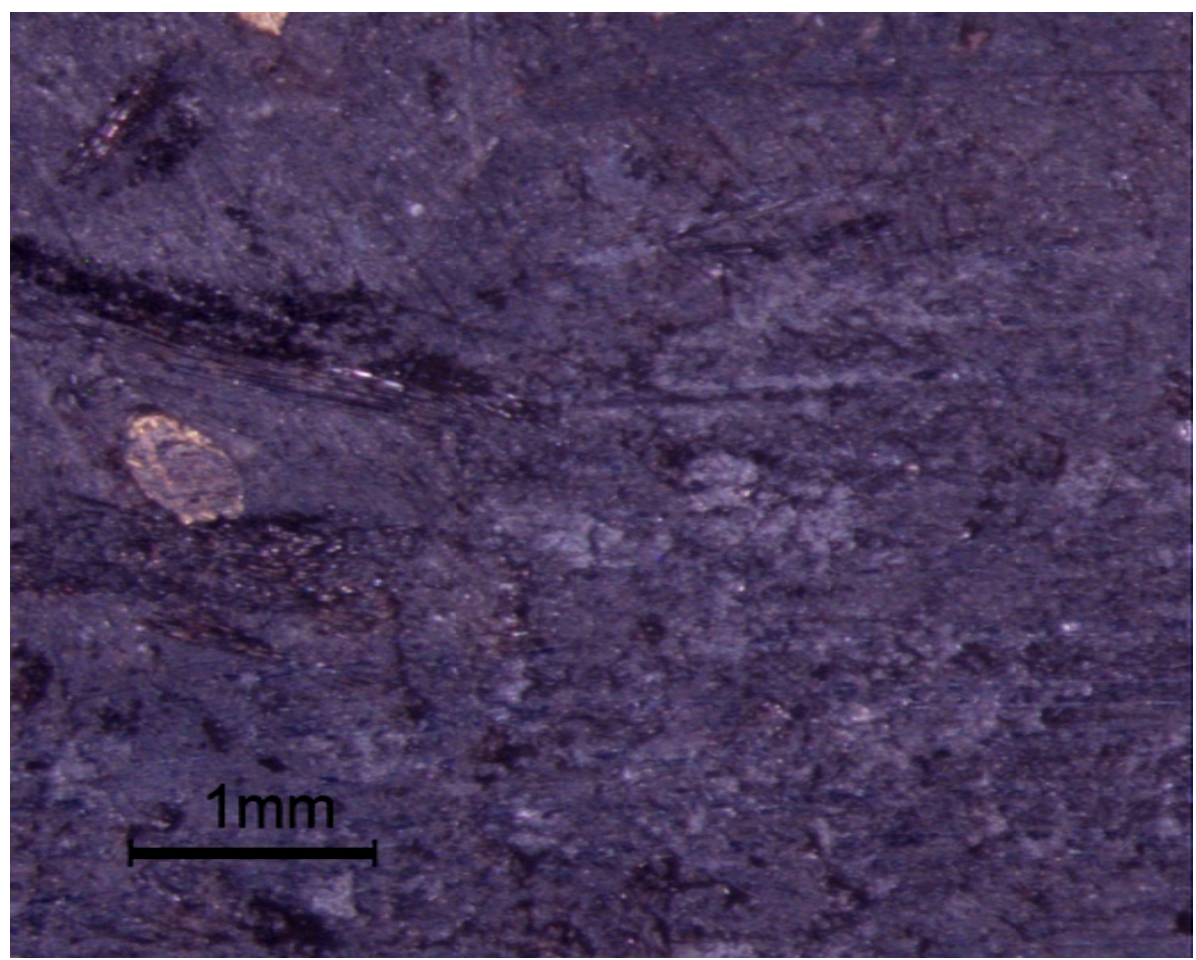

Figura C.5: CP 1 (ensaio $60 \mathrm{~N}$ de carga e $1000 \mathrm{RPM}$ ), foto 5.

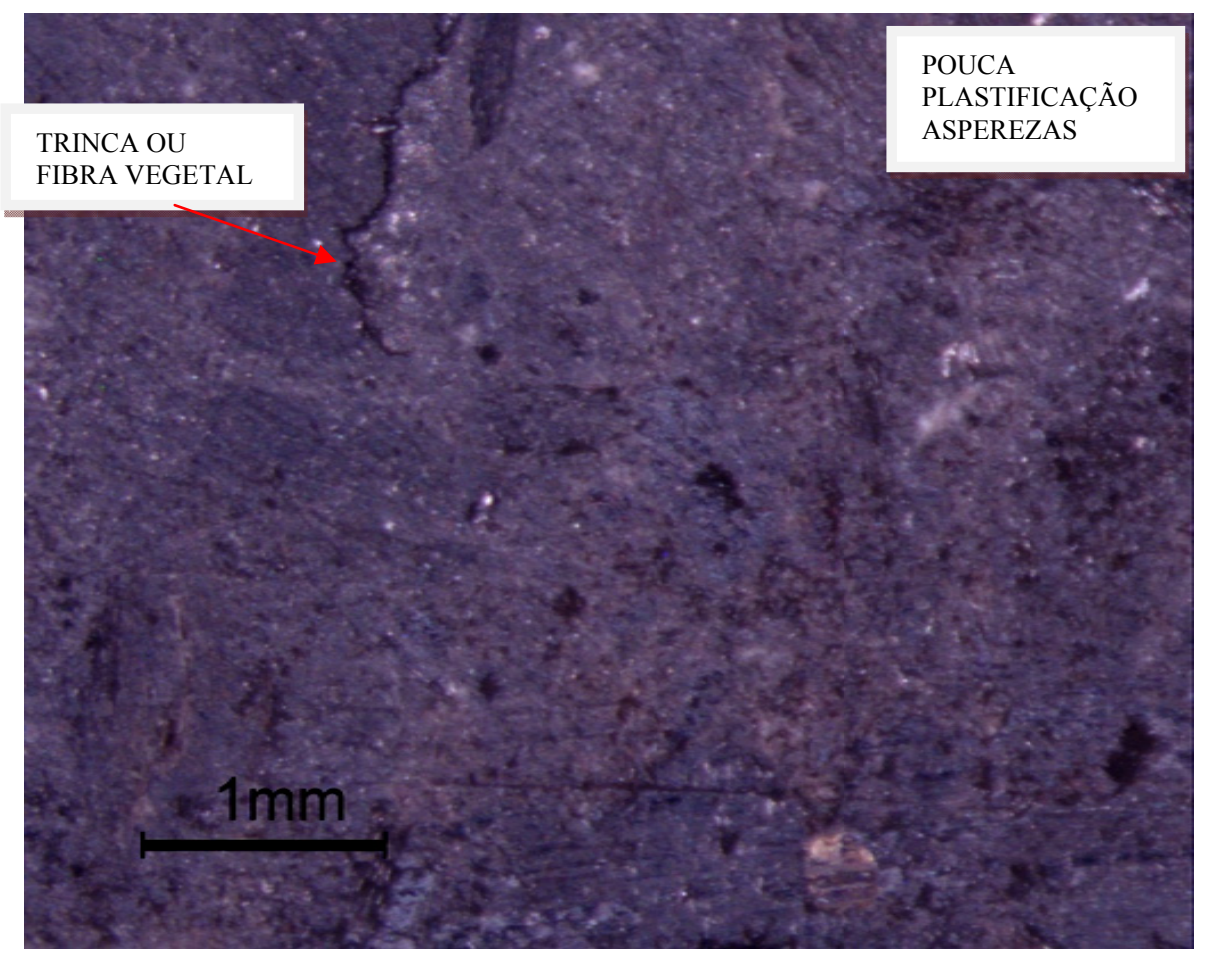

Figura C.6: CP 1 (ensaio $60 \mathrm{~N}$ de carga e $1000 \mathrm{RPM}$ ), foto 6. 


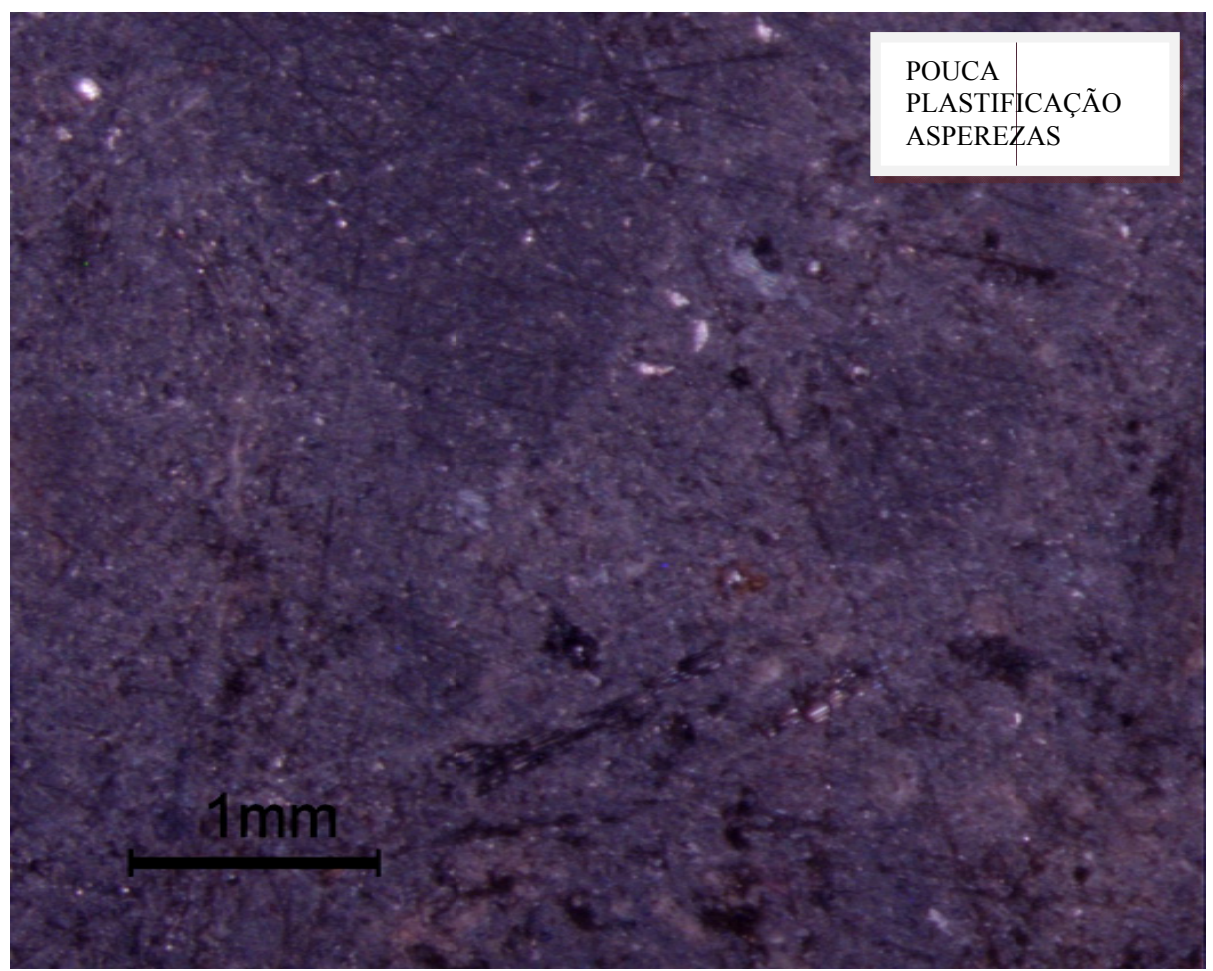

Figura C.7: CP 1 (ensaio $60 \mathrm{~N}$ de carga e 1000 RPM), foto 7.

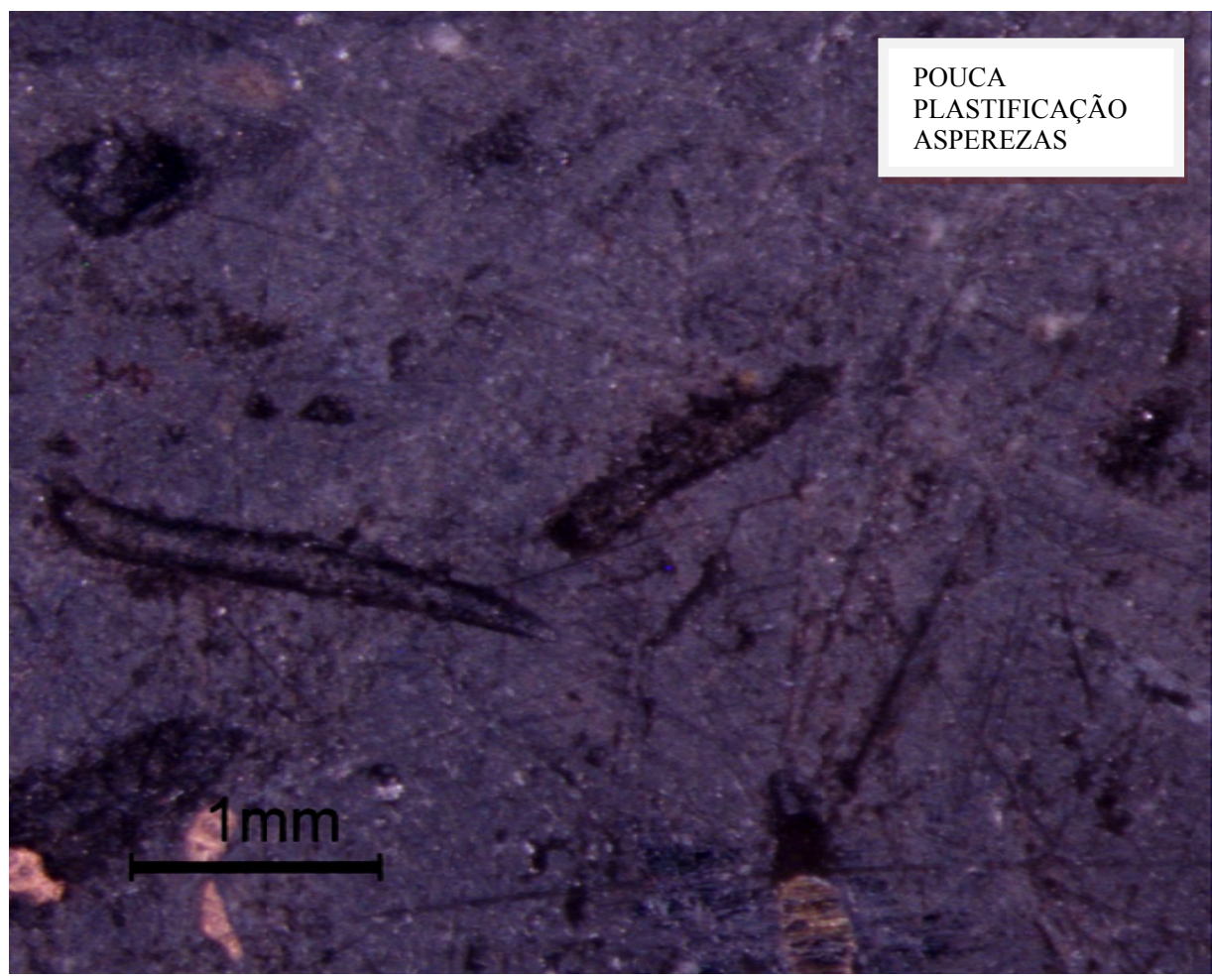

Figura C.8: CP 1 (ensaio $60 \mathrm{~N}$ de carga e $1000 \mathrm{RPM}$ ), foto 8.

O corpo-de-prova 1 em uma de suas extremidades tinha mais asperezas que na outra e nota-se sua plastificação. Uma extremidade do corpo de prova também tem uma distribuição bem diferente de carga. 


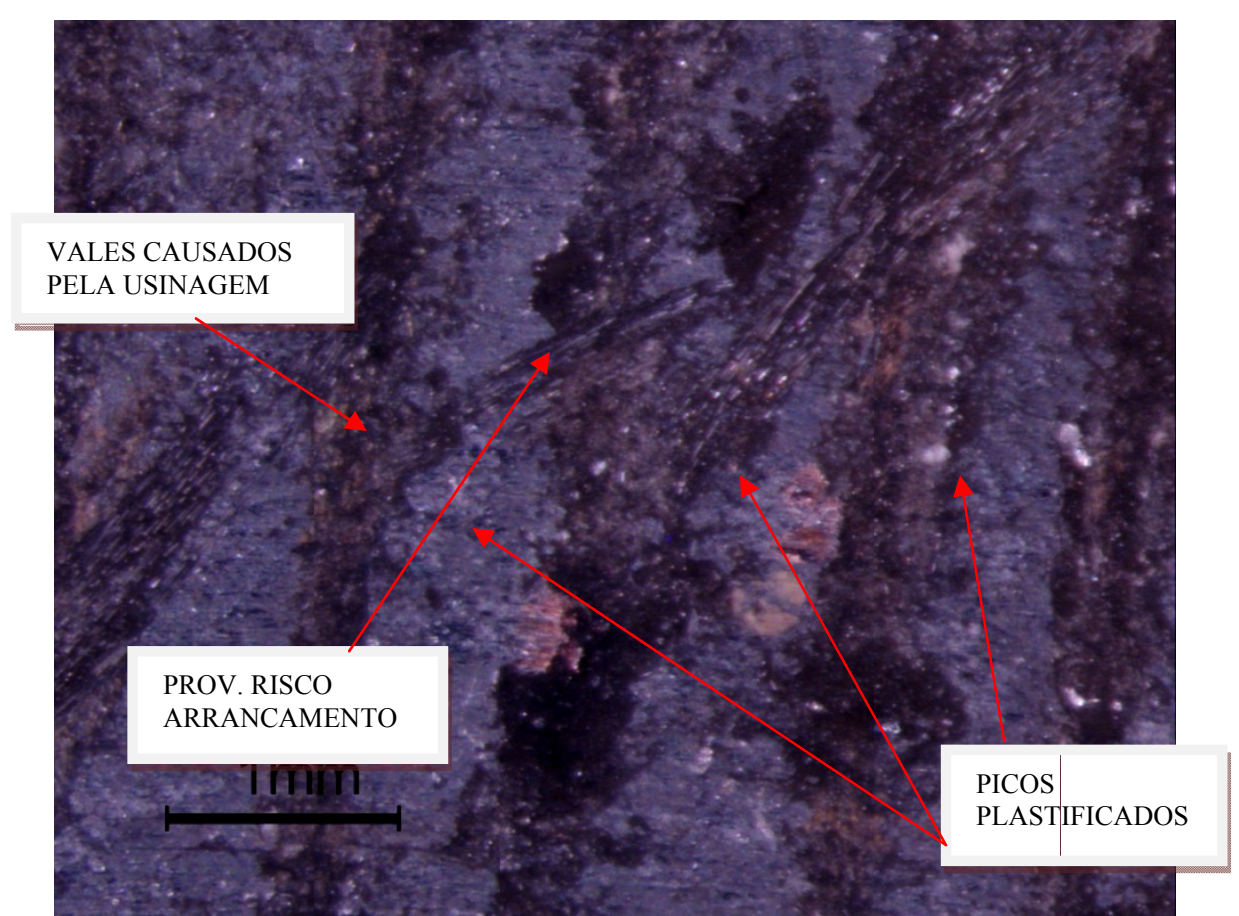

Figura C.9: CP 2 (ensaio $60 \mathrm{~N}$ de carga e $1000 \mathrm{RPM}$ ), foto 1.

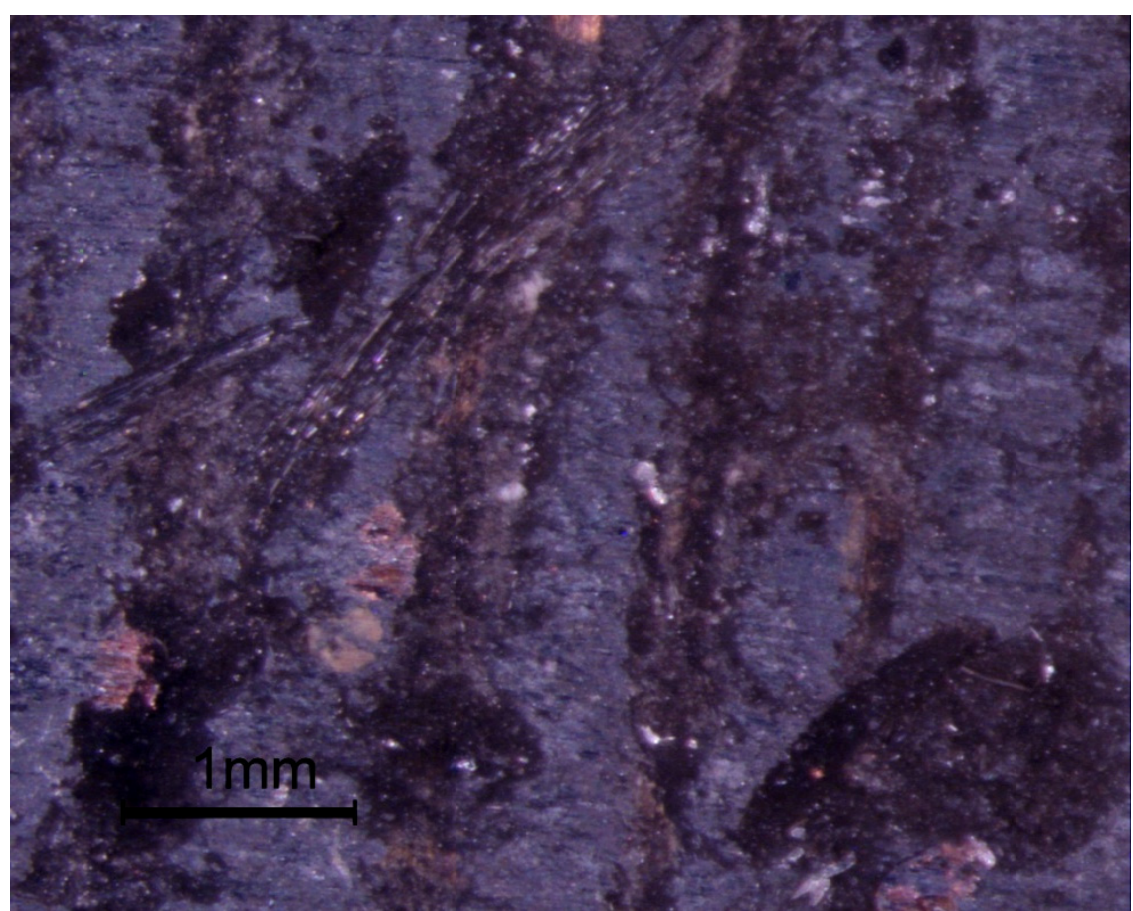

Figura C.10: CP 2 (ensaio $60 \mathrm{~N}$ de carga e 1000 RPM), foto 2. 


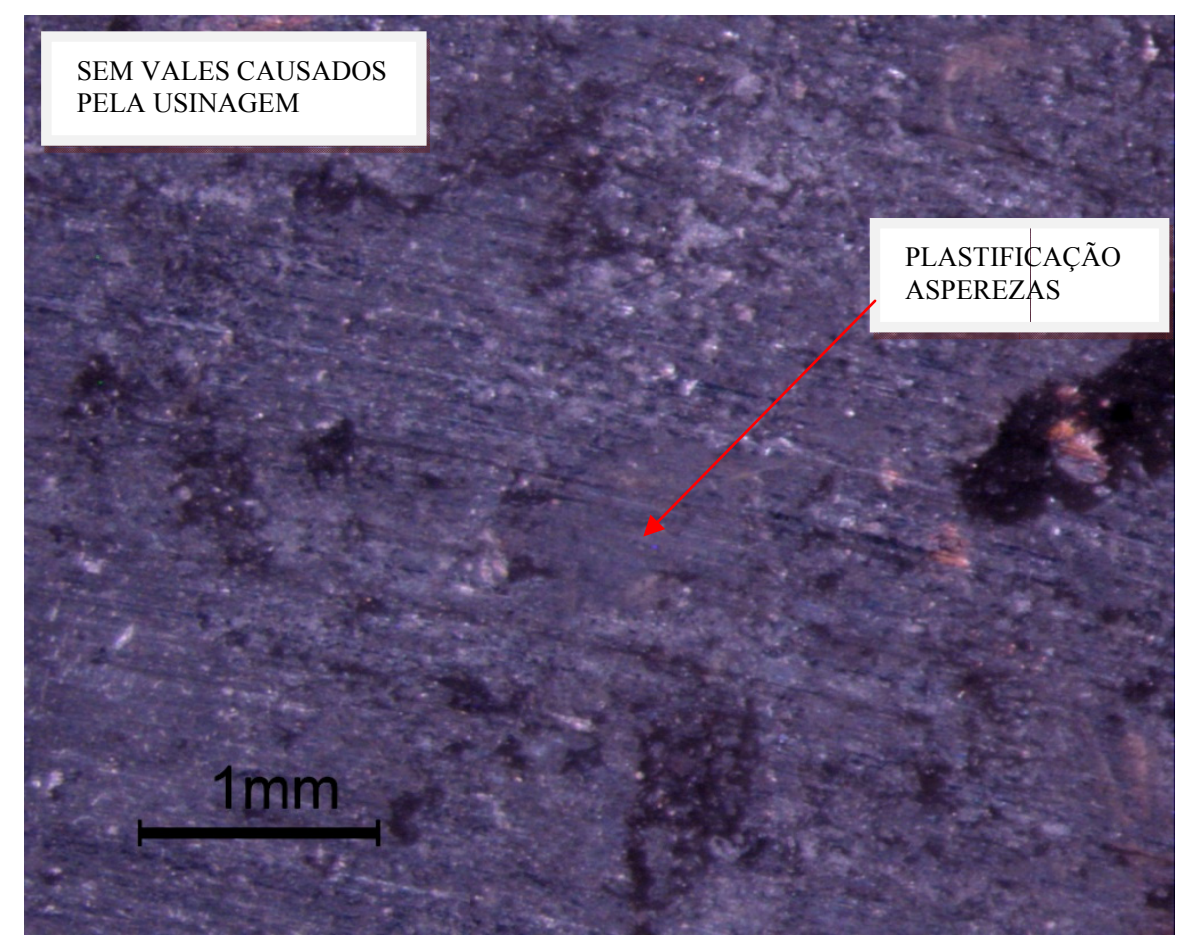

Figura C.11: CP 2 (ensaio $60 \mathrm{~N}$ de carga e 1000 RPM), foto 3

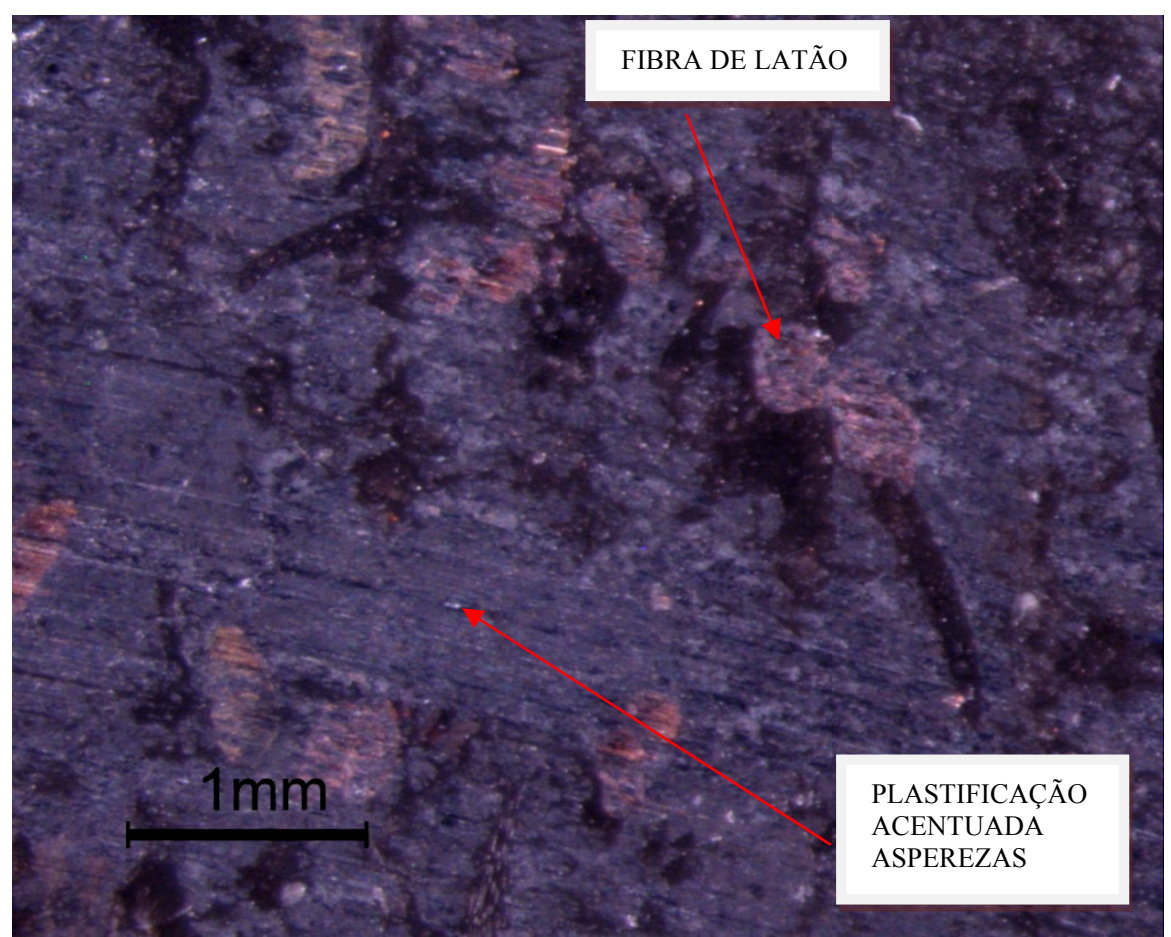

Figura C.12: CP 2 (ensaio $60 \mathrm{~N}$ de carga e $1000 \mathrm{RPM}$ ), foto 4 


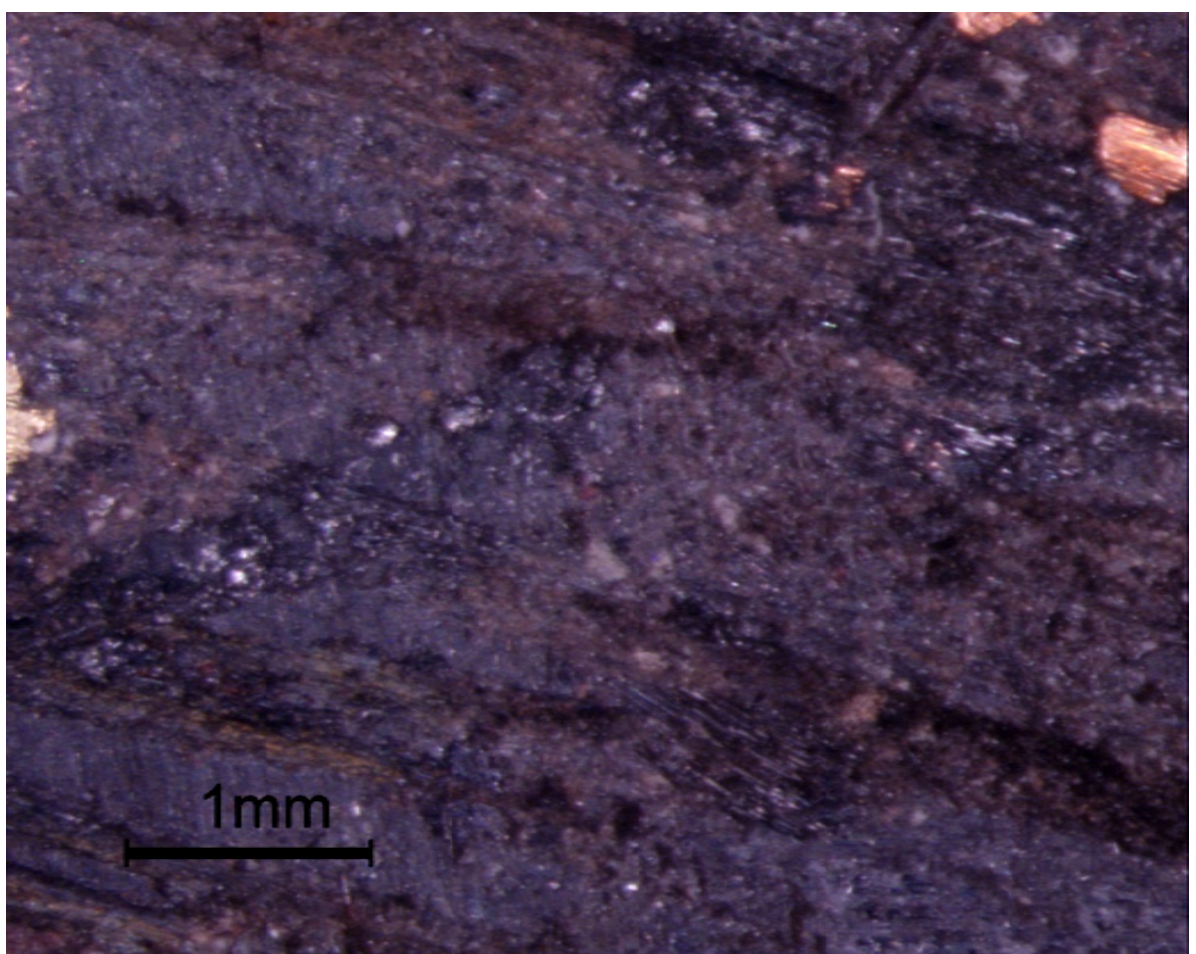

Figura C.13: CP 3 (ensaio $60 \mathrm{~N}$ de carga e $1000 \mathrm{RPM}$ ), foto 1

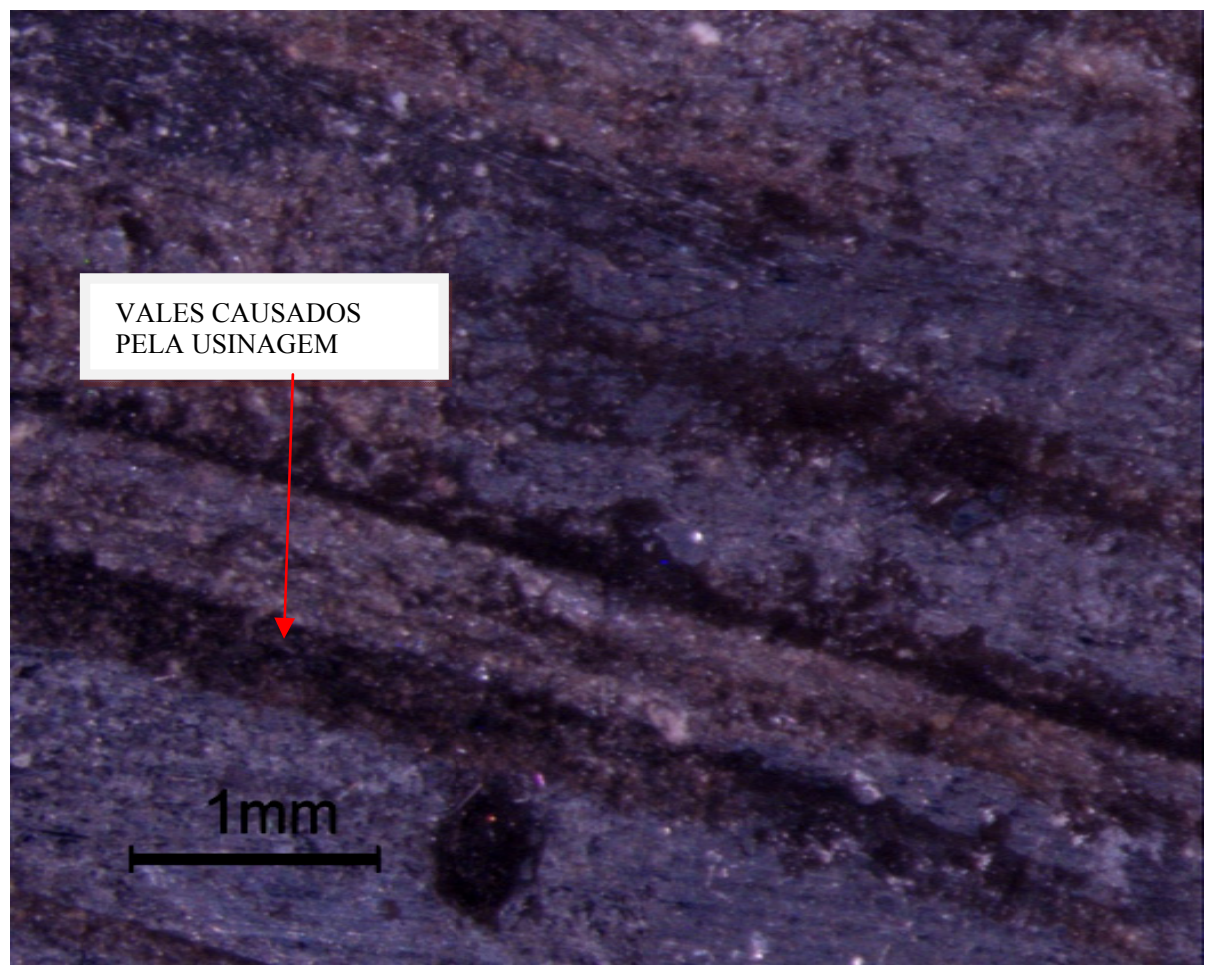

Figura C.14: CP 3 (ensaio $60 \mathrm{~N}$ de carga e 1000 RPM), foto 2 


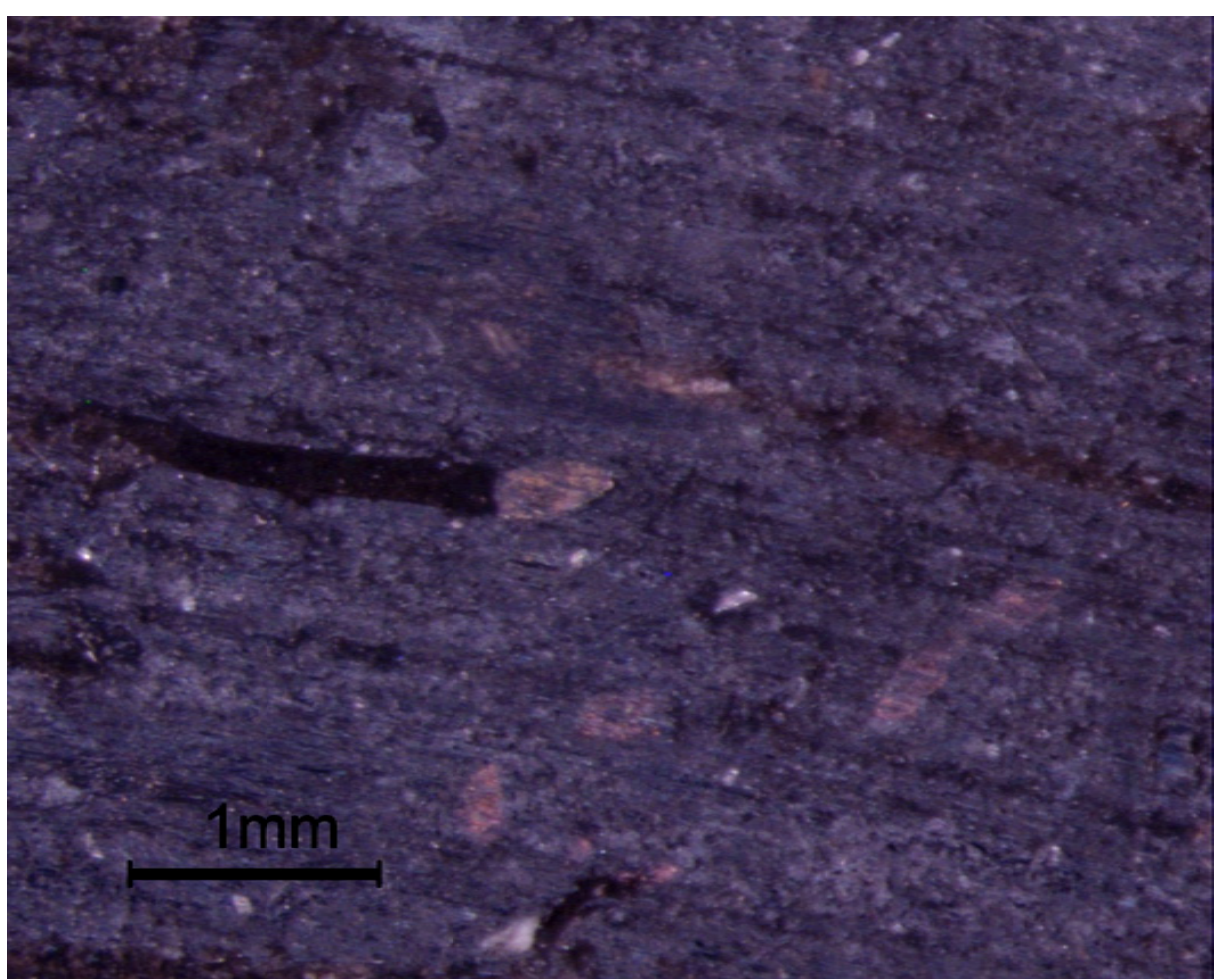

Figura C.15: CP 3 (ensaio $60 \mathrm{~N}$ de carga e $1000 \mathrm{RPM}$ ), foto 3

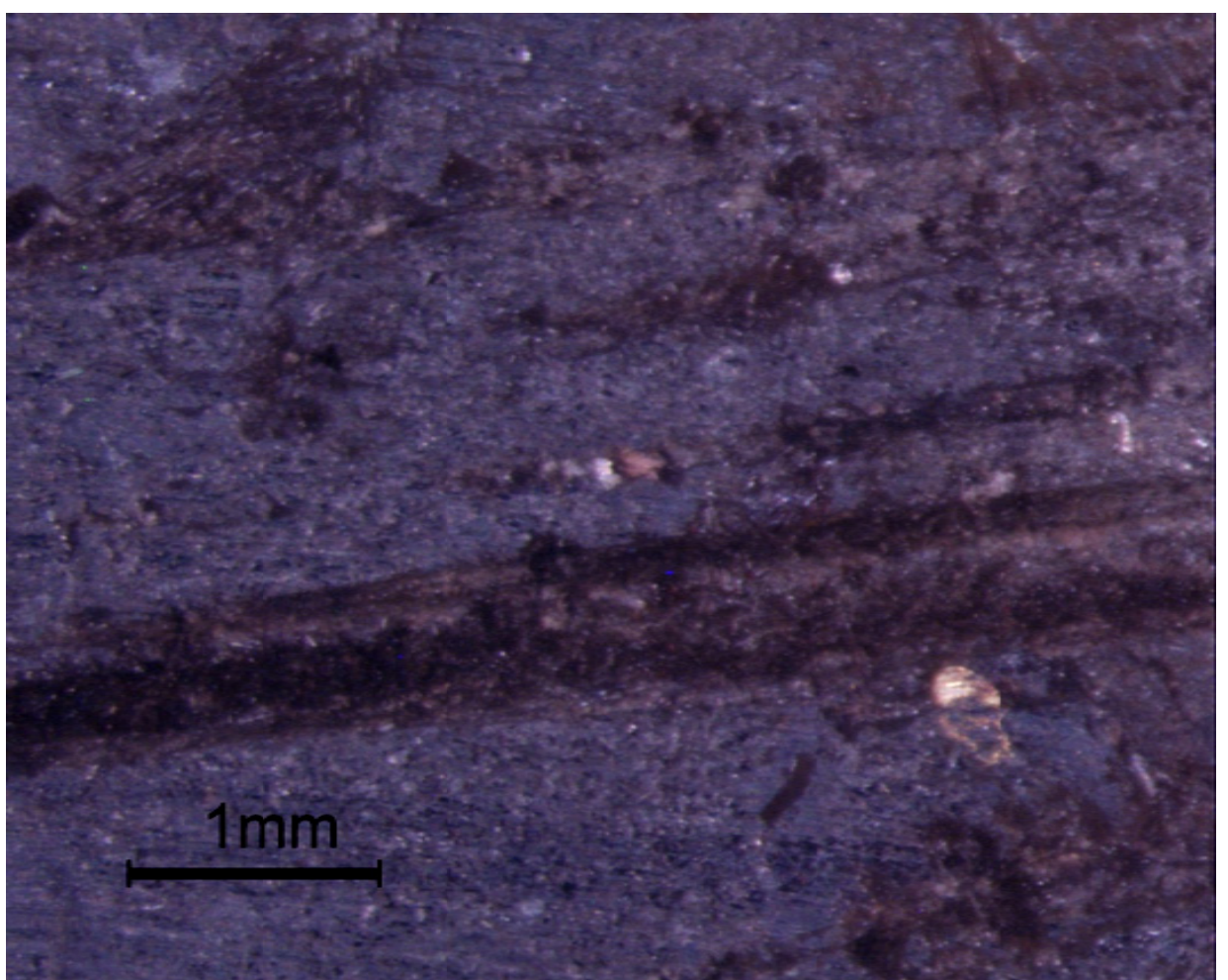

Figura C.16: CP 3 (ensaio $60 \mathrm{~N}$ de carga e $1000 \mathrm{RPM}$ ), foto 4 
Ensaios com $180 \mathrm{~N}$ de carga e 1000 RPM.

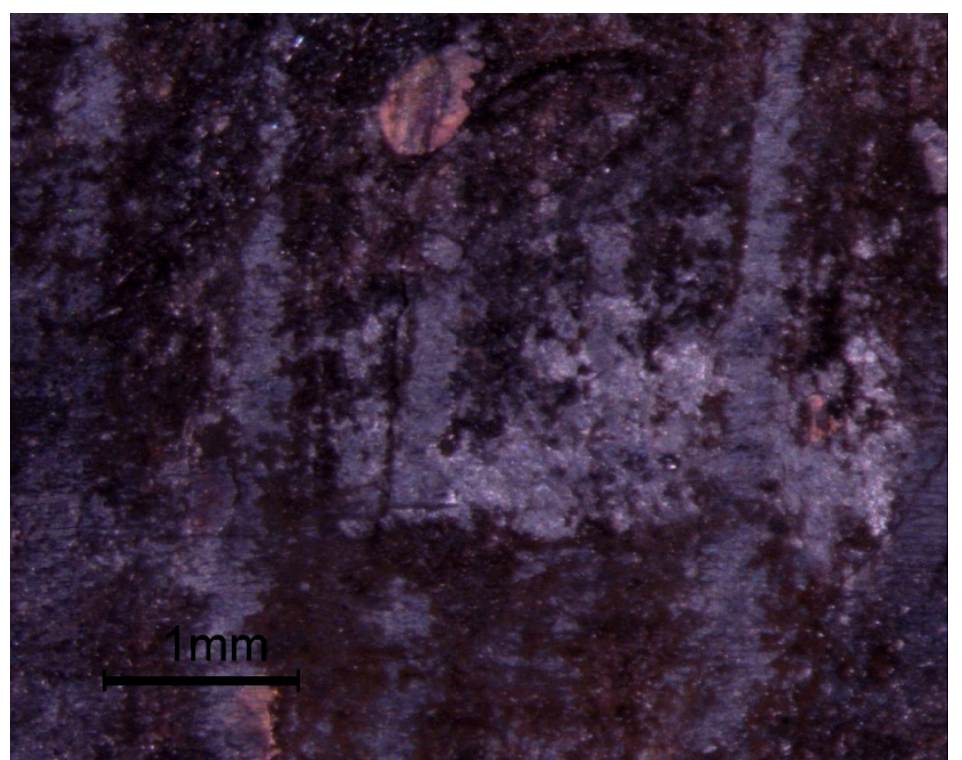

Figura C.17: CP 4 (ensaio $180 \mathrm{~N}$ de carga e $1000 \mathrm{RPM}$ ), foto 1

A Fig. C.17 tem o mesmo brilho e contraste que as anteriores, notam-se sua cor mais escura, que as fotos anteriores. Para uma melhor visualização na fig. C. 18 foi diminuído o contraste em $20 \%$ e nas seguintes será feito o mesmo.

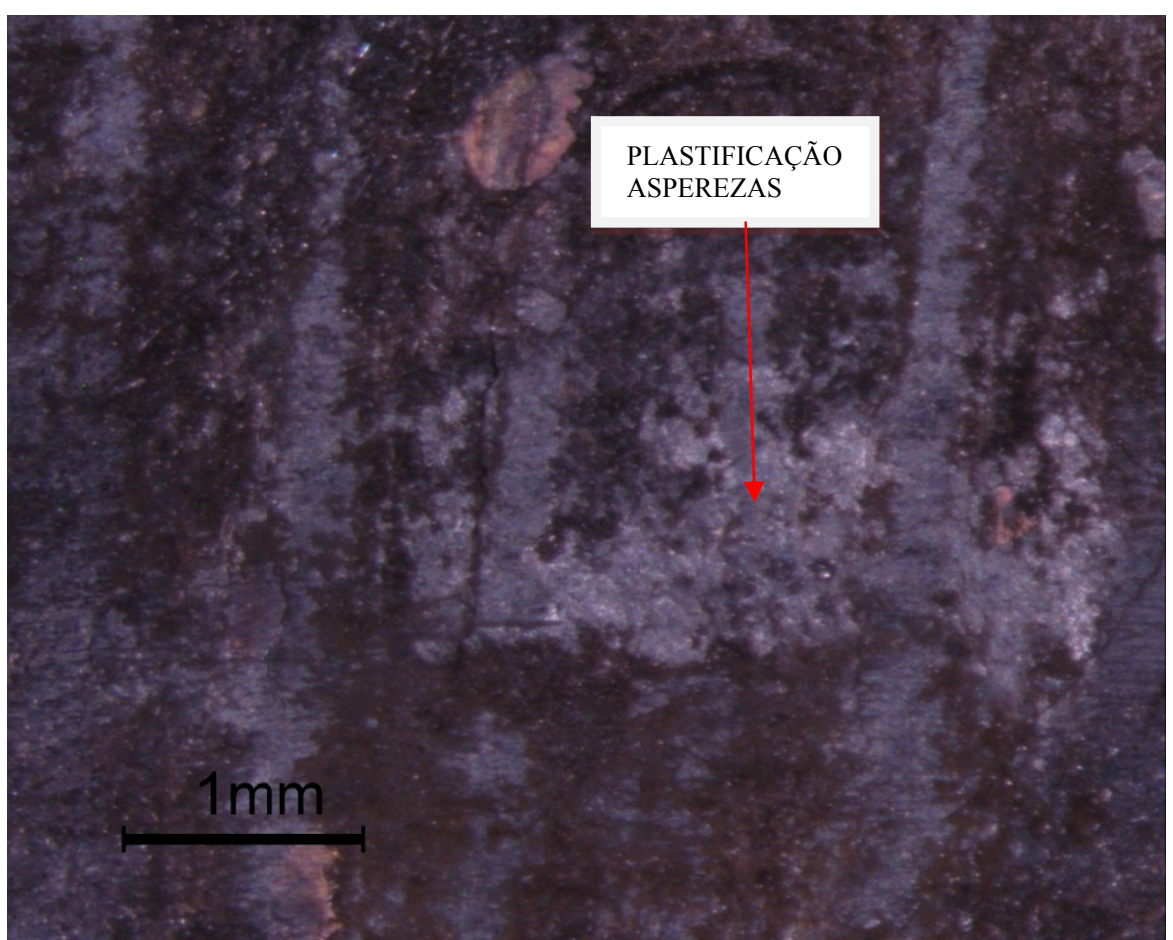

Figura C.18: CP 4 (ensaio $180 \mathrm{~N}$ de carga e $1000 \mathrm{RPM}$ ), foto 1.A 


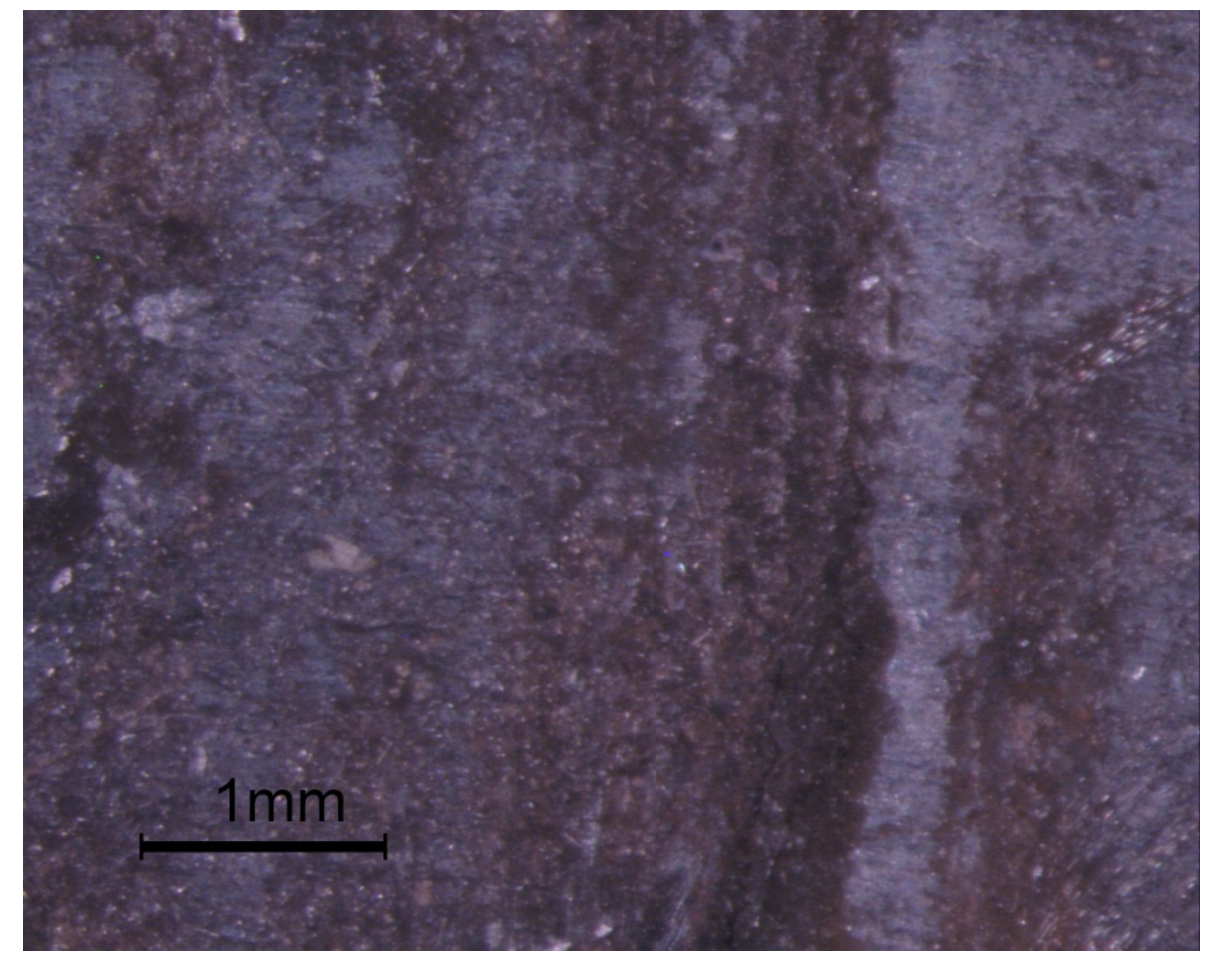

Figura C.19: CP 4 (ensaio $180 \mathrm{~N}$ de carga e $1000 \mathrm{RPM}$ ), foto 2

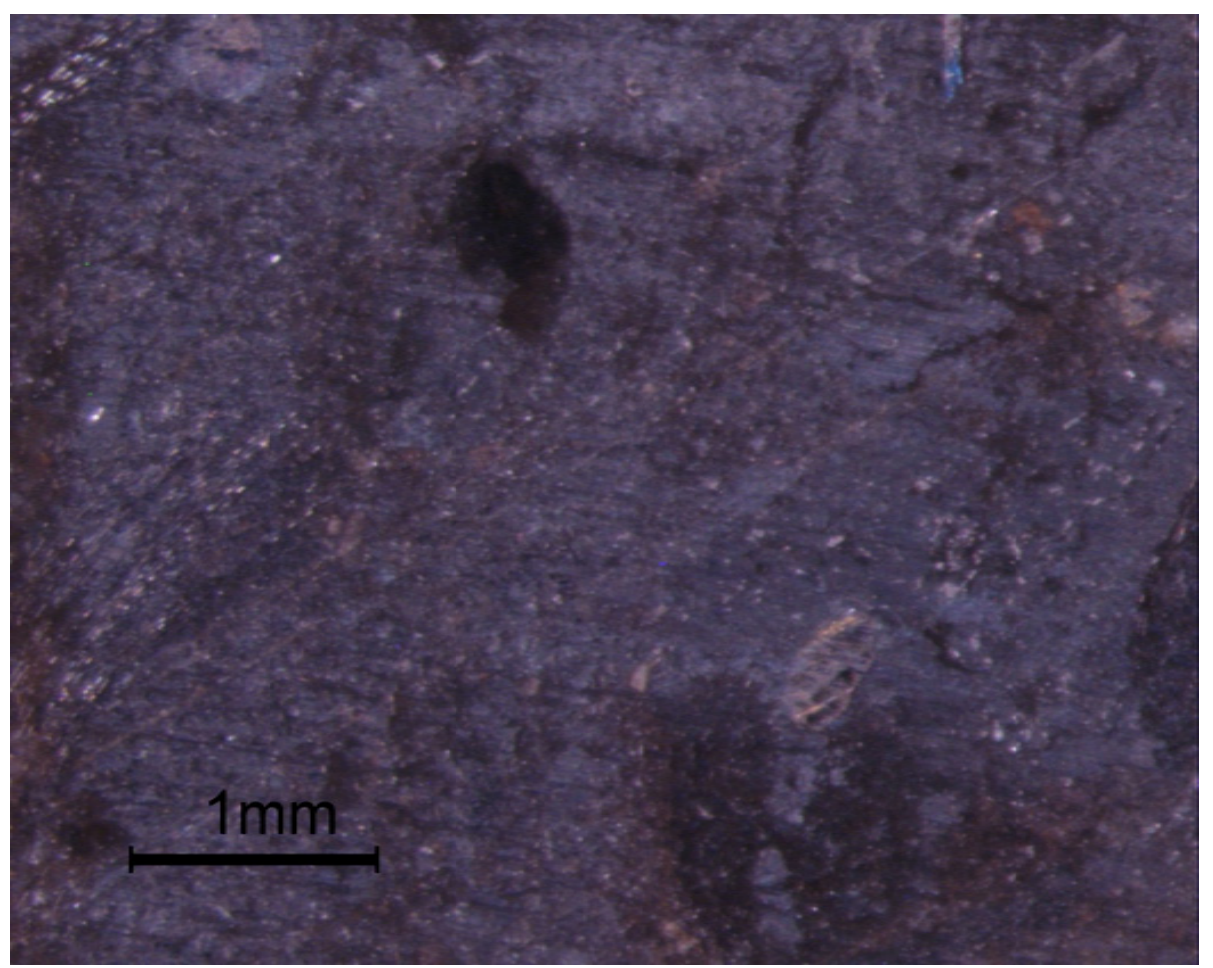

Figura C.20: CP 4 (ensaio $180 \mathrm{~N}$ de carga e $1000 \mathrm{RPM}$ ), foto 3 


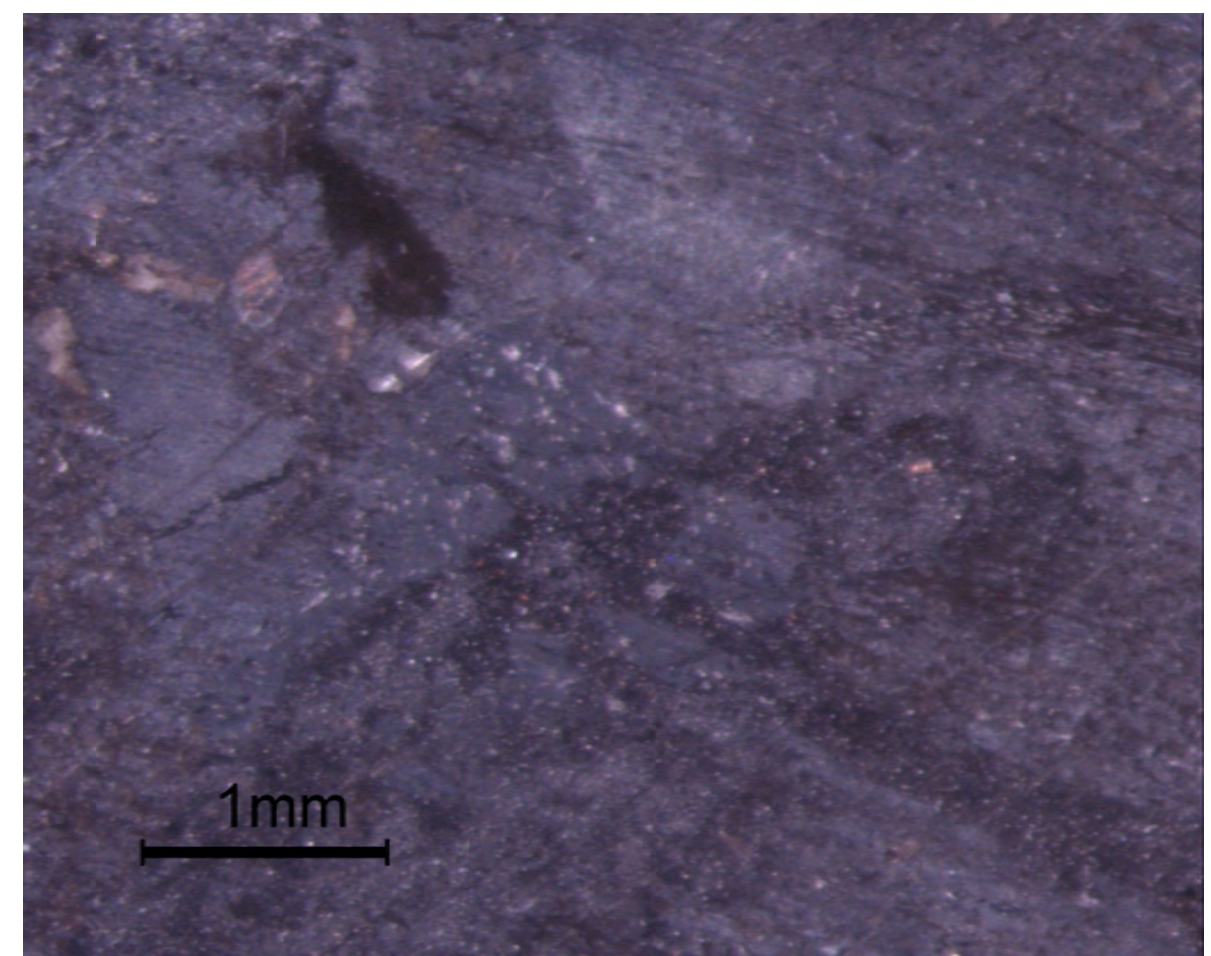

Figura C.21: CP 4 (ensaio $180 \mathrm{~N}$ de carga e 1000 RPM), foto 4

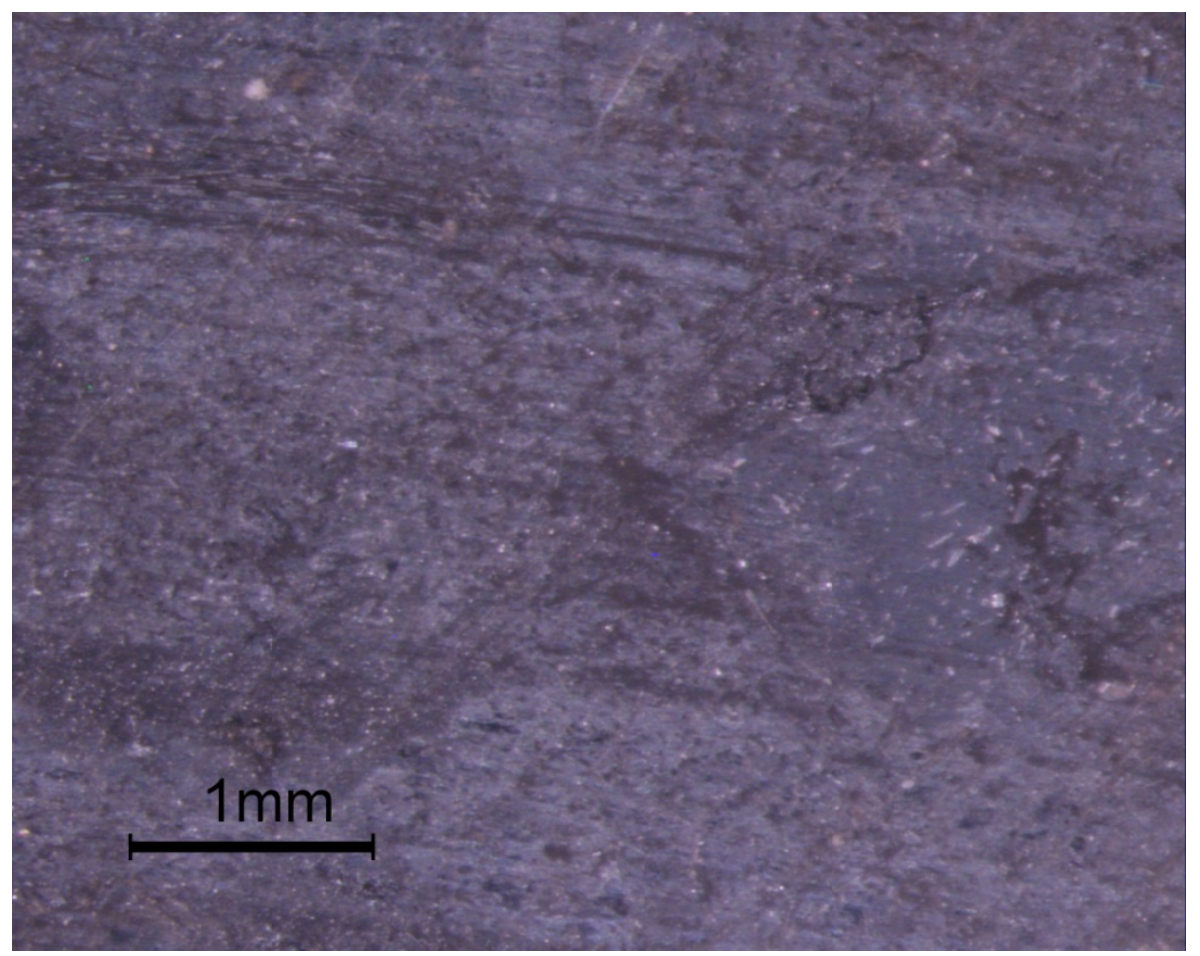

Figura C.22: CP 4 (ensaio $180 \mathrm{~N}$ de carga e 1000 RPM), foto 5 
Ensaios com $240 \mathrm{~N}$ de carga e 1000 RPM.

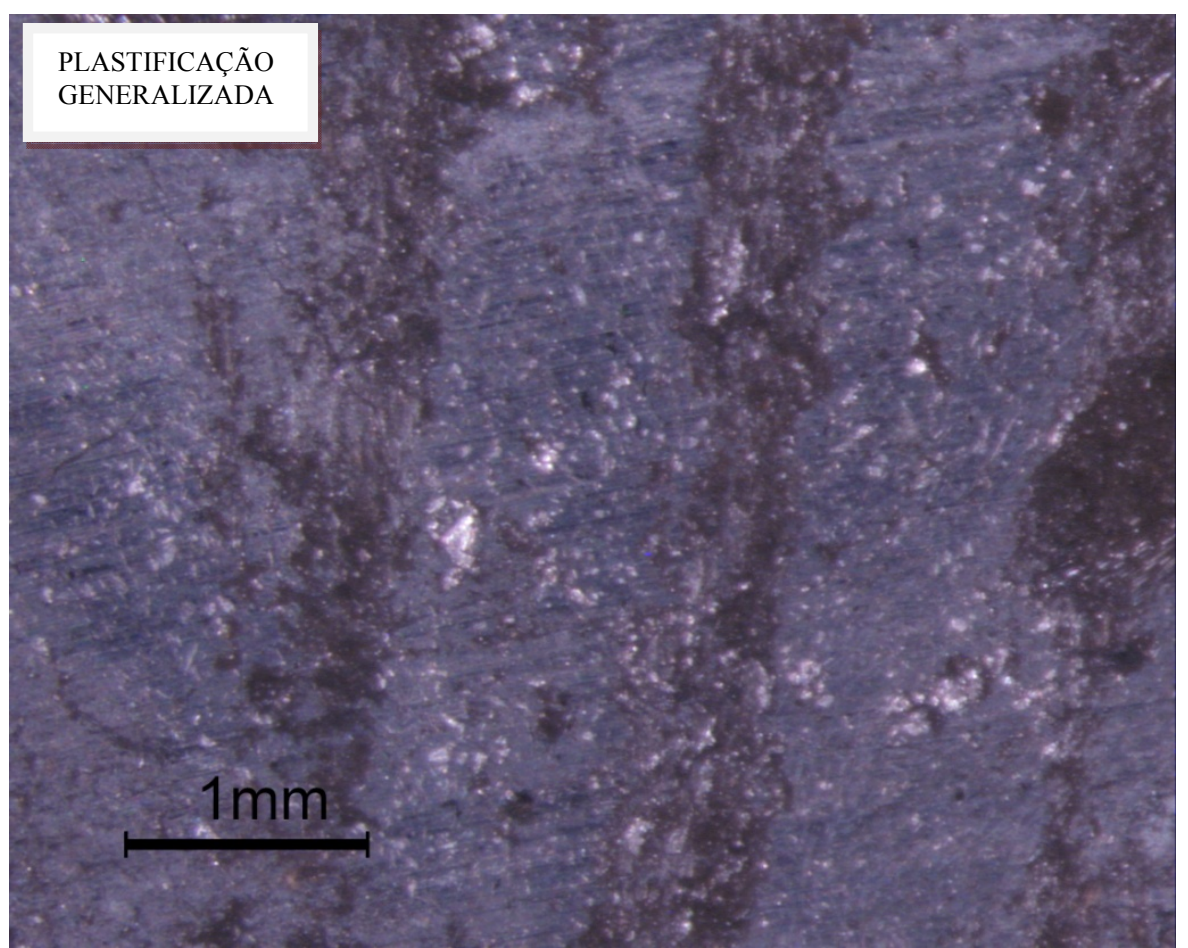

Figura C.23: CP 5 (ensaio $240 \mathrm{~N}$ de carga e $1000 \mathrm{RPM}$ ), foto 1

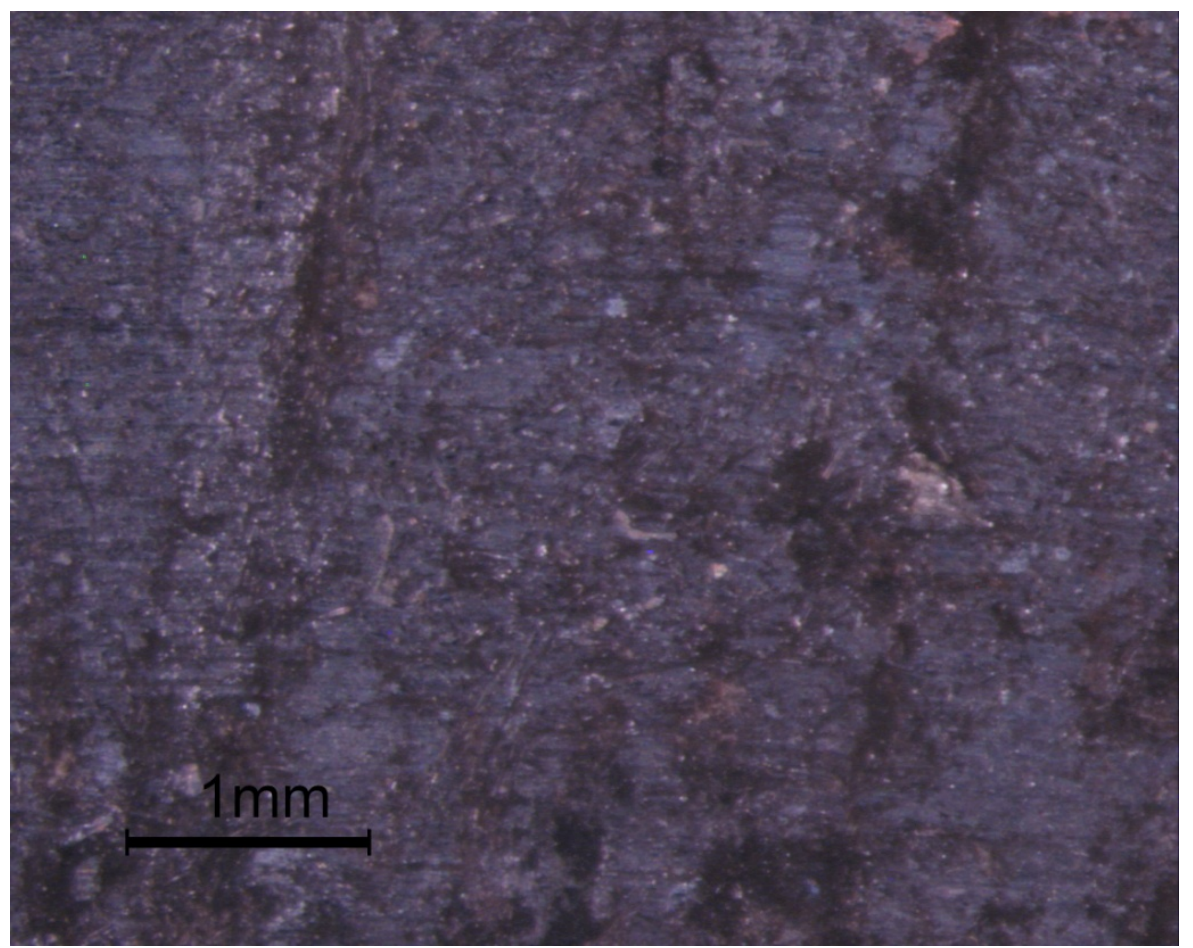

Figura C.24: CP 5 (ensaio $240 \mathrm{~N}$ de carga e 1000 RPM), foto 2 


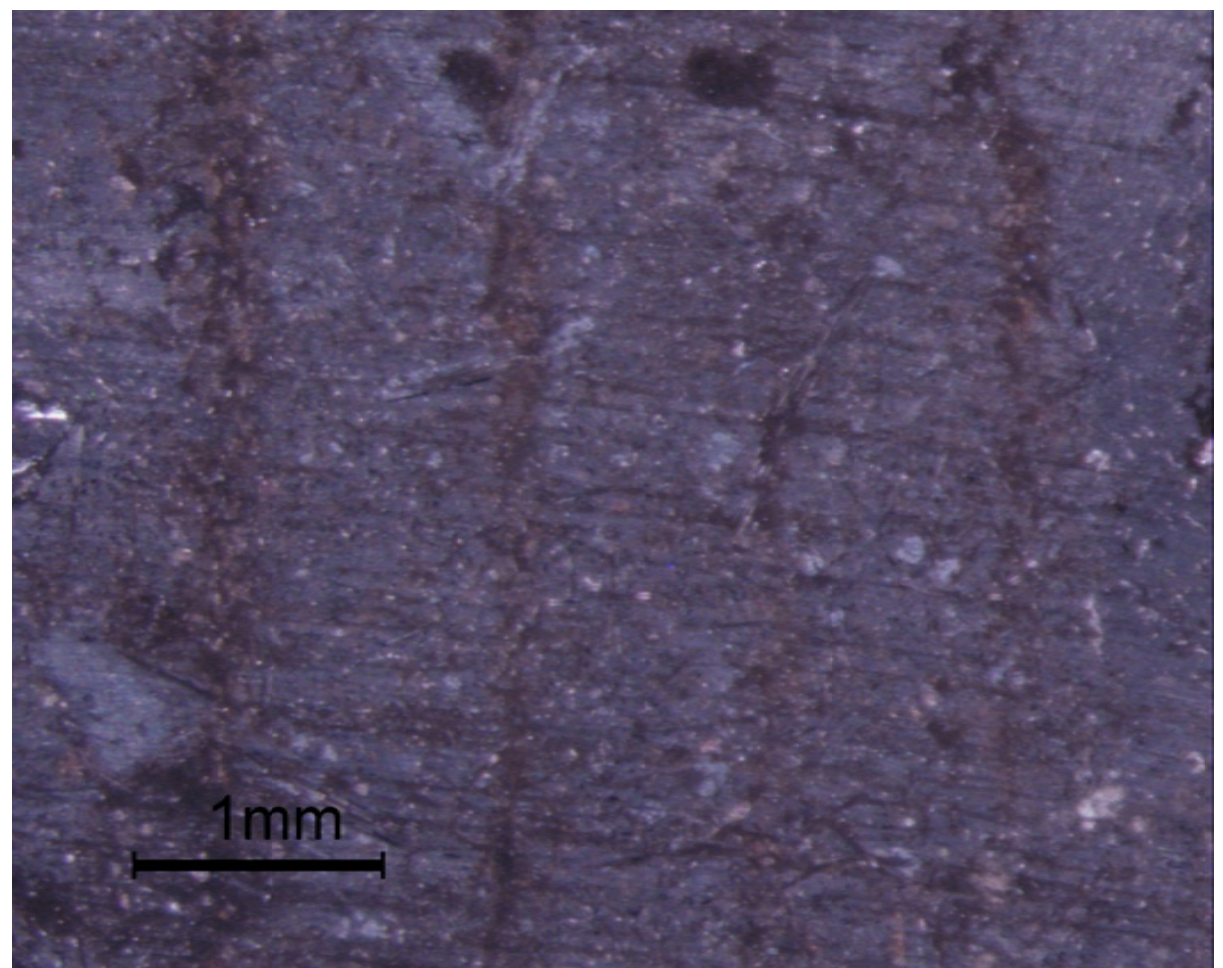

Figura C.25: CP 5 (ensaio $240 \mathrm{~N}$ de carga e $1000 \mathrm{RPM}$ ), foto 3

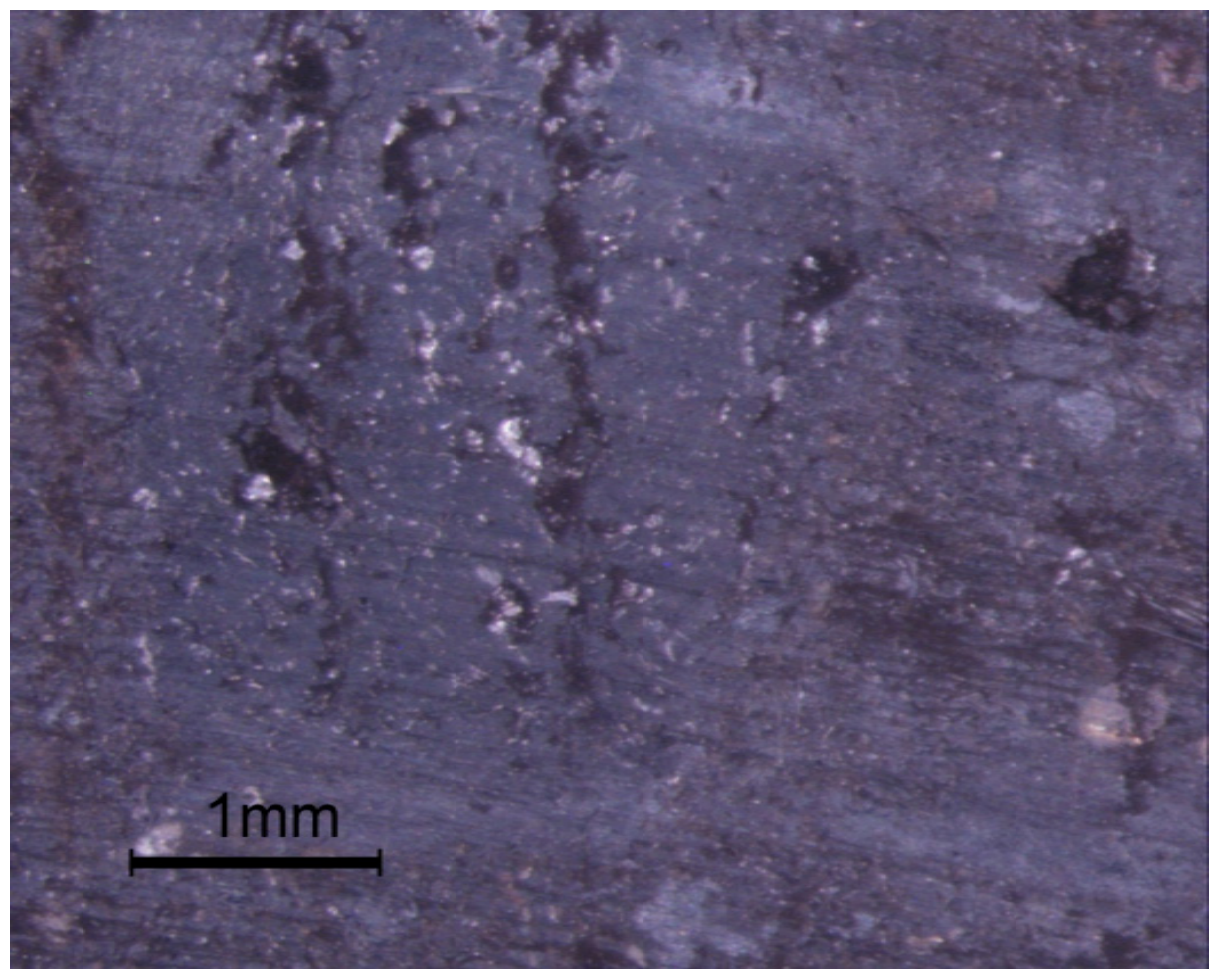

Figura C.26: CP 5 (ensaio $240 \mathrm{~N}$ de carga e $1000 \mathrm{RPM}$ ), foto 4 


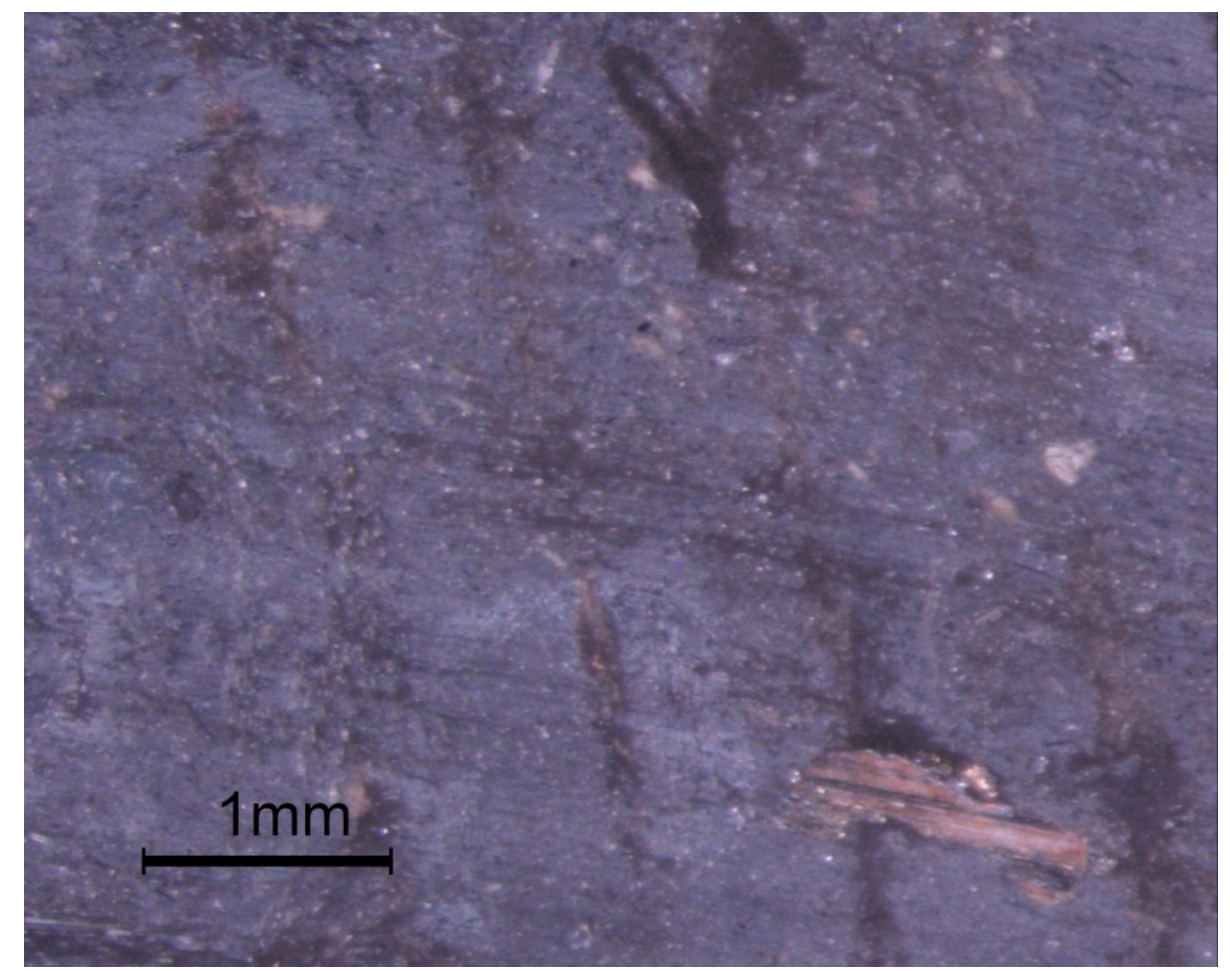

Figura C.27: CP 5 (ensaio $240 \mathrm{~N}$ de carga e $1000 \mathrm{RPM})$, foto 5

Nos ensaios até $120 \mathrm{~N}$ (mostradas as fotos de corpos-de-prova ensaios de 60 N) nota-se que temos deformações plásticas das aperezas, em algumas regiões com acabamento superficial de pior qualidade há um maior número destas deformações plásticas. Rodrigues (2007) mostra na fabricação das lonas (fig. 2.14) o acabamento final por retífica. Tal procedimento não ocorre usualmente nas lonas de maior porte usadas na manutenção industrial e notase nas figuras dos ensaios de $60 \mathrm{~N}$ sua influencia.

Folgas e alinhamento dos componentes podem gerar contatos não paralelos (pressão de contato não uniforme), Schumann (2006) analisa esse problema para freios a disco automotivos. Nas regiões de maior pressão há um desgaste mais acentuado. Sugere-se em manutenções verificação de folgas e trocas dos elementos de guia desgastados e em novas embreagens um controle dimensional rígido para diminuir possíveis folgas.

Nos ensaios com pressões de contato maiores (180 N e $240 \mathrm{~N}$ ) nota-se deformações plásticas em toda a extensão da trilha e de forma generalizada. Também se nota que o corpo-de-prova está bem mais escuro. 


\section{ANEXO D - FOTOS DE LONAS DESGASTADAS}

\section{EMBREAGEM DE PRENSA}

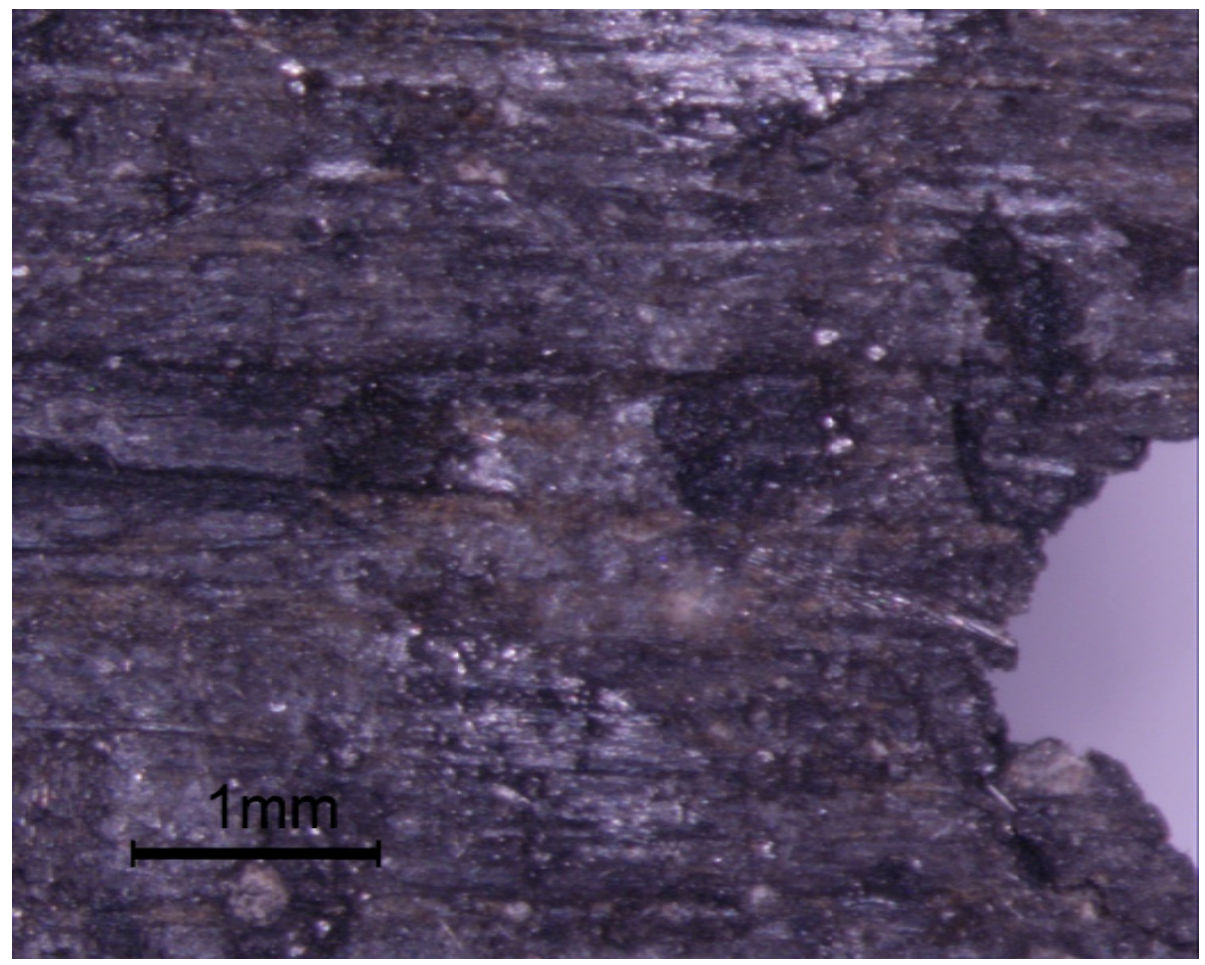

Figura D.1: Lona usada de embreagem, foto 1.

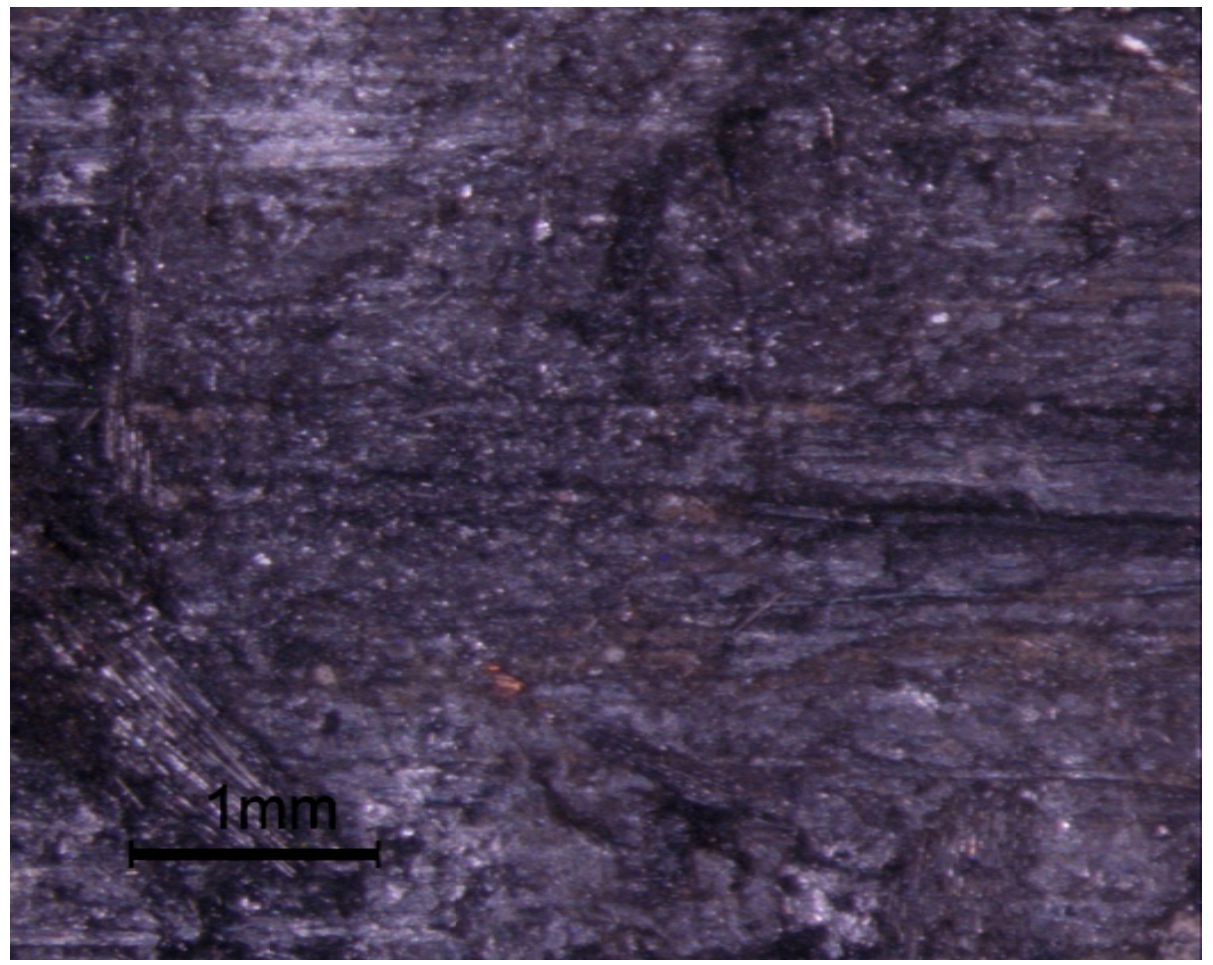

Figura D.2: Lona usada de embreagem, foto 2. 


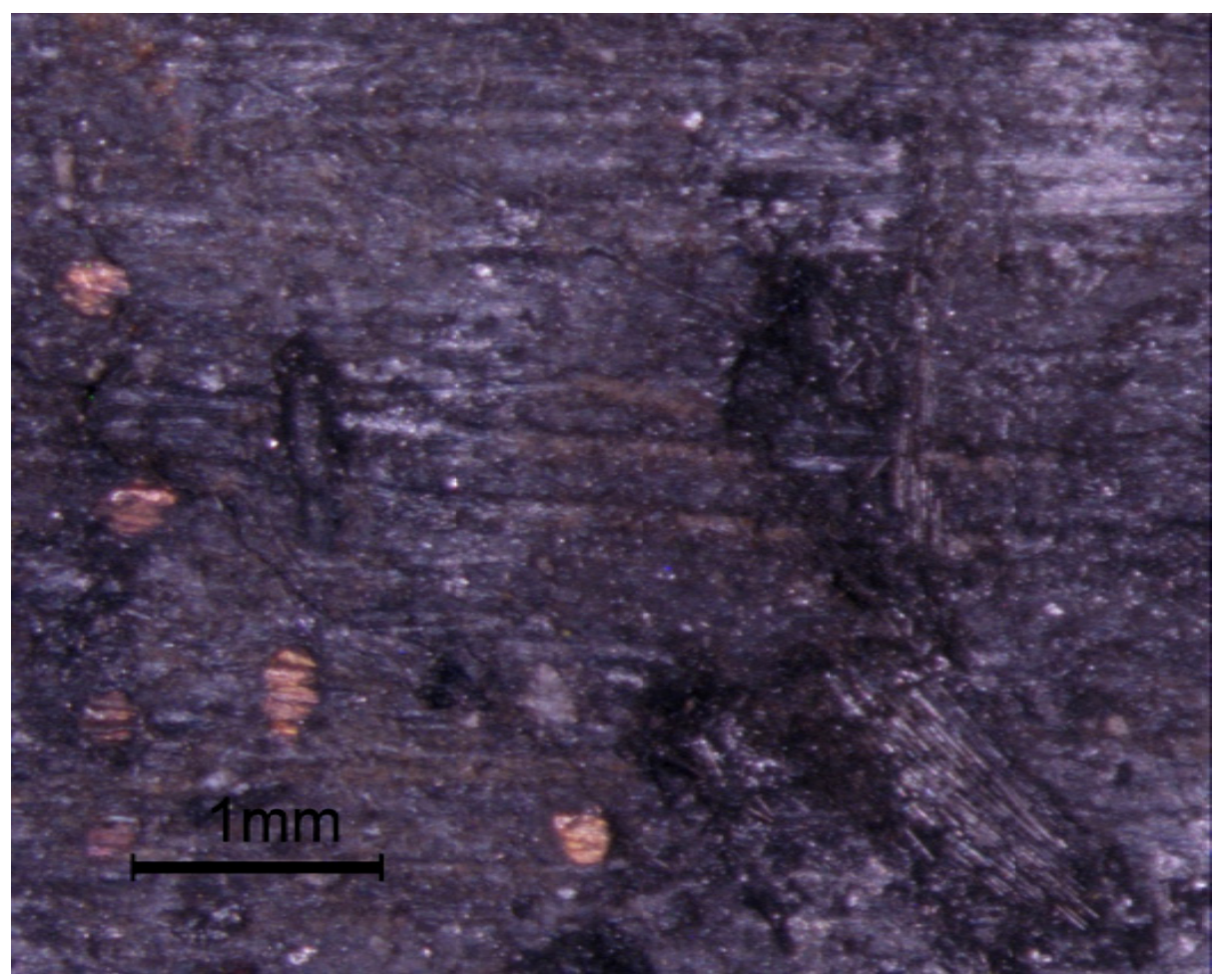

Figura D.3: Lona usada de embreagem, foto 3.

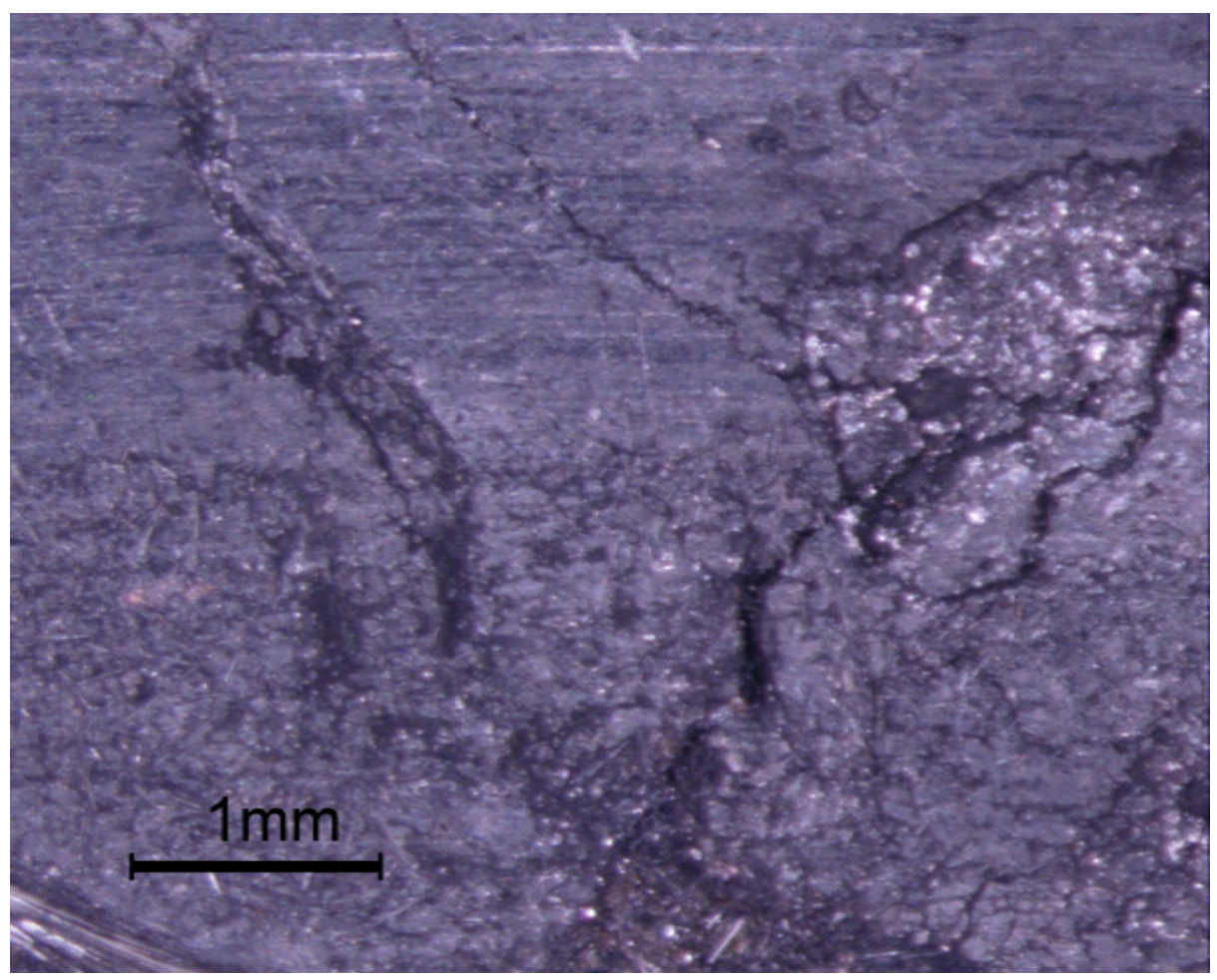

Figura D.4: Lona usada de embreagem, foto 4. 


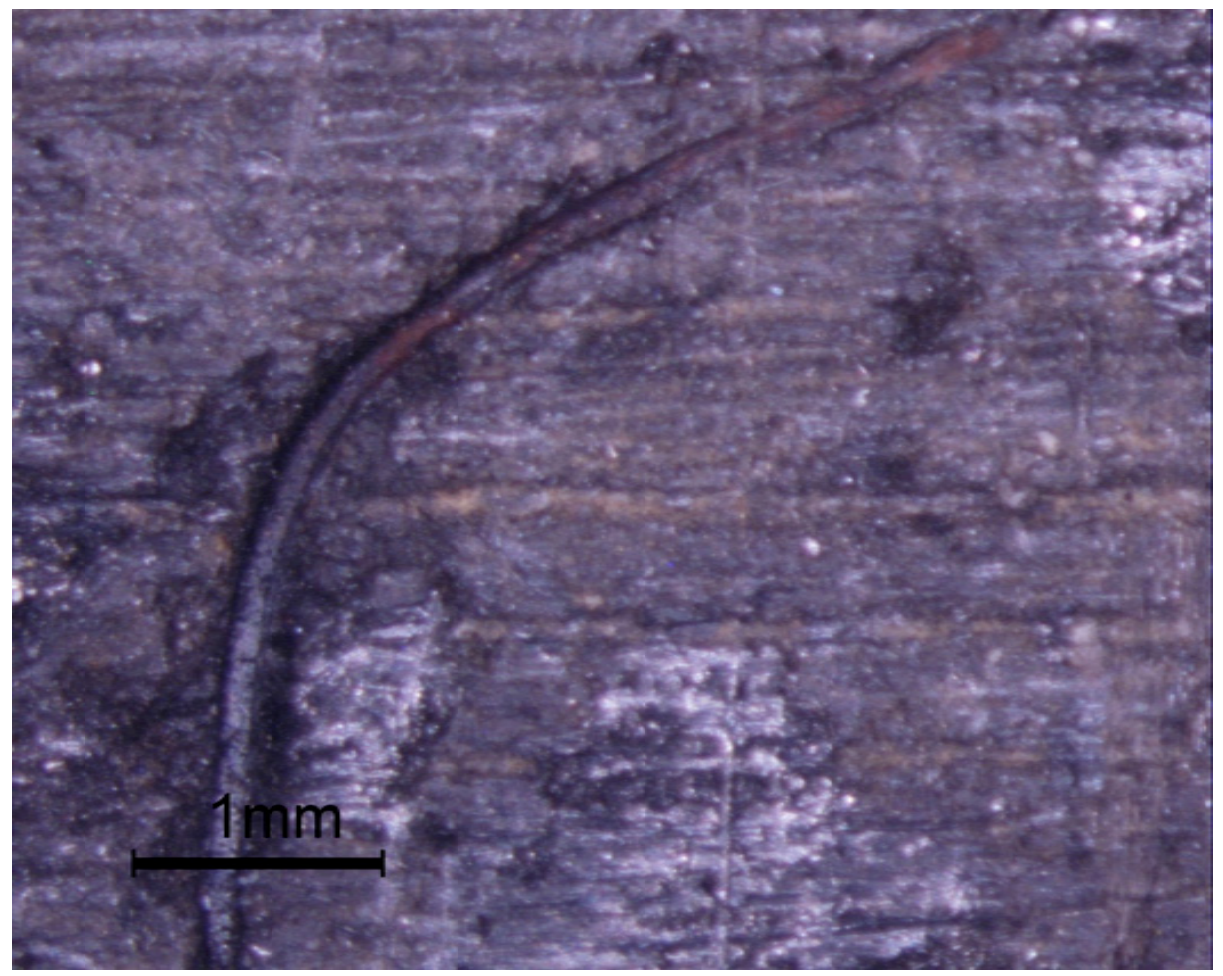

Figura D.5: Lona usada de embreagem mostra uma fibra se soltando, foto 5.

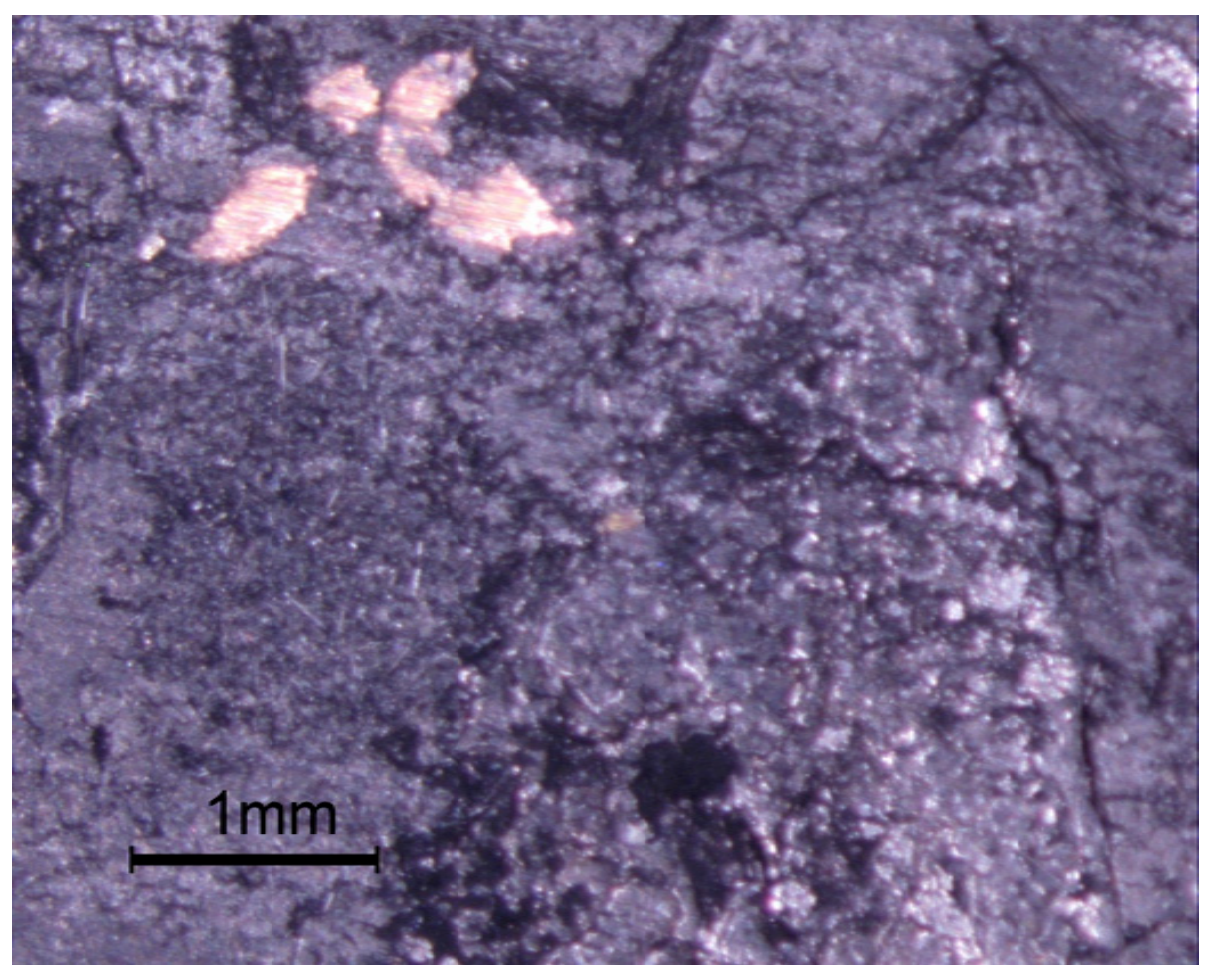

Figura D.6: Lona usada de embreagem, foto 6 


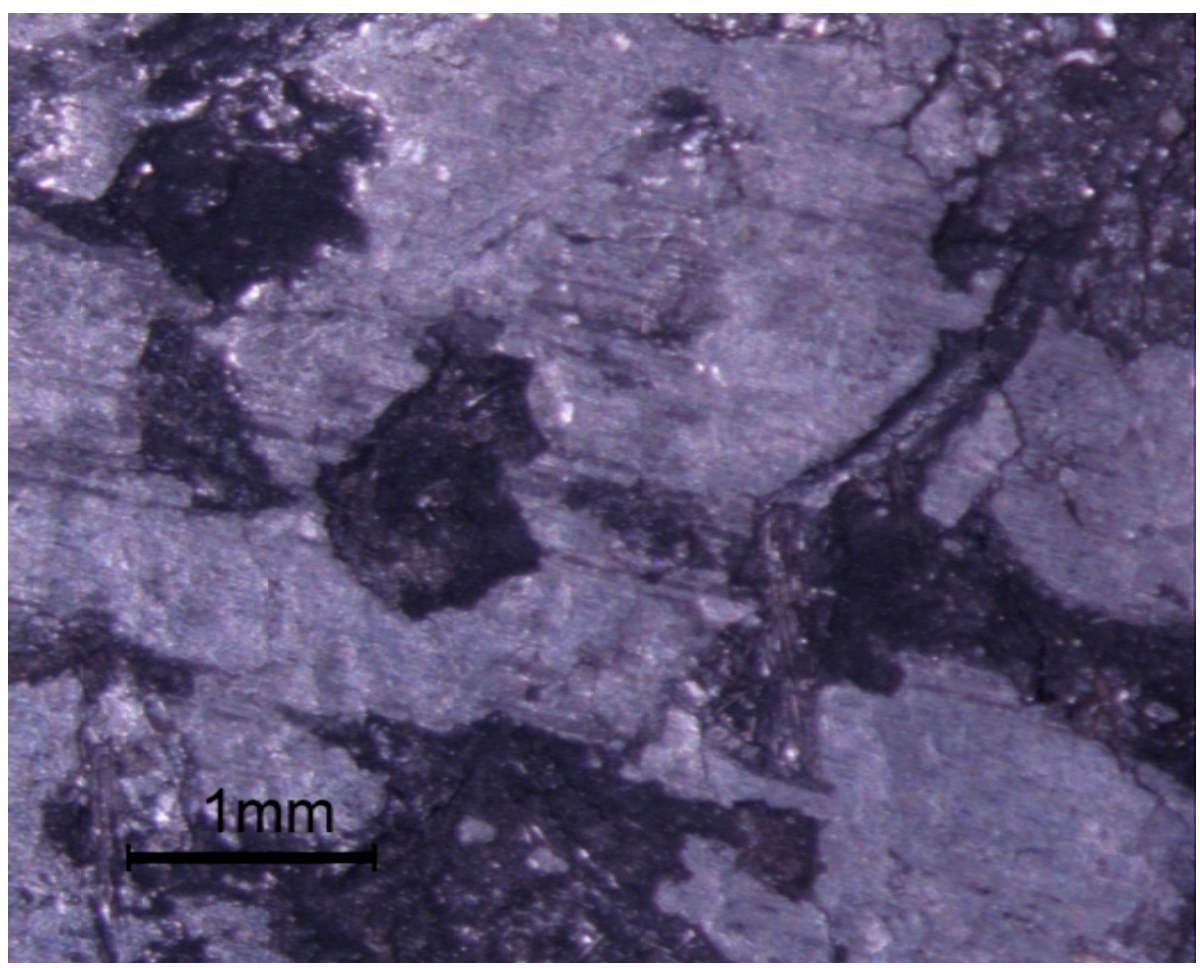

Figura D.7: Lona usada de embreagem, foto 7

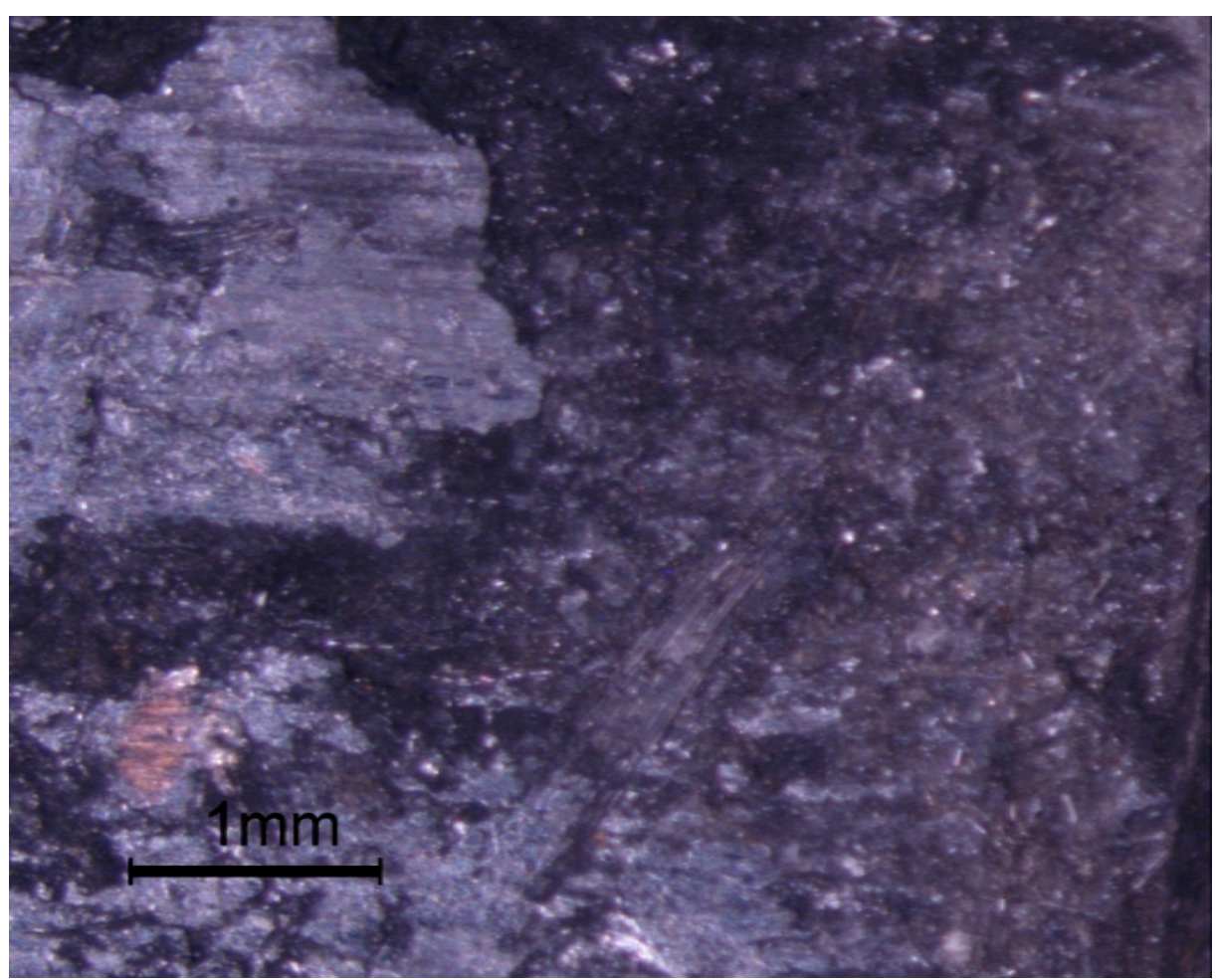

Figura D.8: Lona usada de embreagem, foto 8 


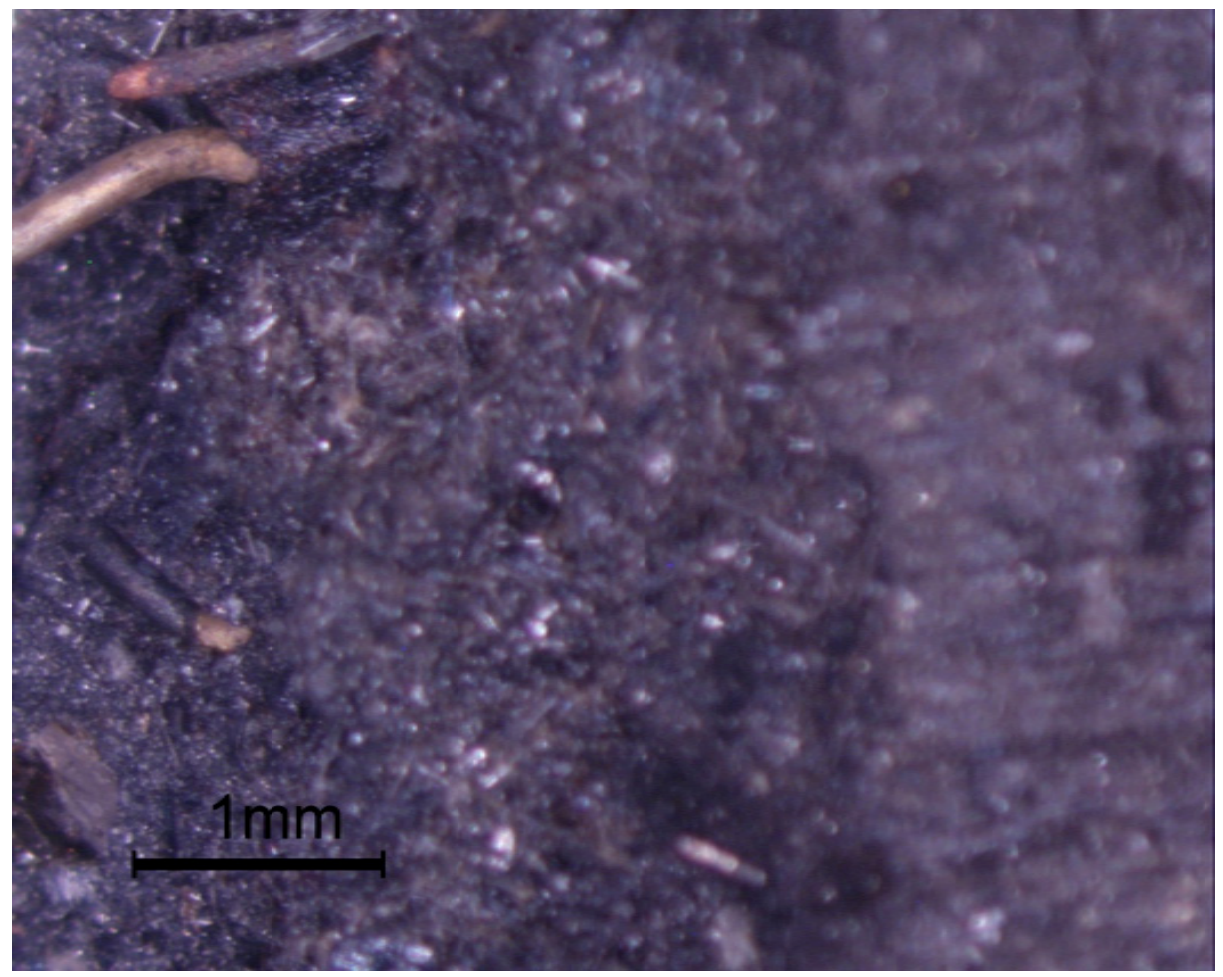

Figura D.9: Lona usada de embreagem, foto 9

De maneira geral pode-se afirmar que as fotos dessa manutenção são compatíveis com as fotos obtidas nos ensaios com $240 \mathrm{~N}$. Existem grades deformações plásticas de origem térmica, bem como vária trincas. Pode-se dizer analisando apenas as figuras que esta embreagem está no regime severo de desgaste. Ao desmontar-se a embreagem para manutenção notou-se que as lonas centrais estão bem mais avariadas que as externas (é uma embreagem de lamelas múltiplas).

Além de prensas outros equipamentos que apresentam grande desgaste de lonas, um exemplo é a embreagens cônicas de alguns bate-estacas. Equipamentos mais antigos apresentam maiores problemas, em razão de terem sido projetados para lonas com asbestos cujo desempenho é sabidamente superior as lonas sem asbestos. 